MACO TOLEDO DE ASSFS BaSTOS

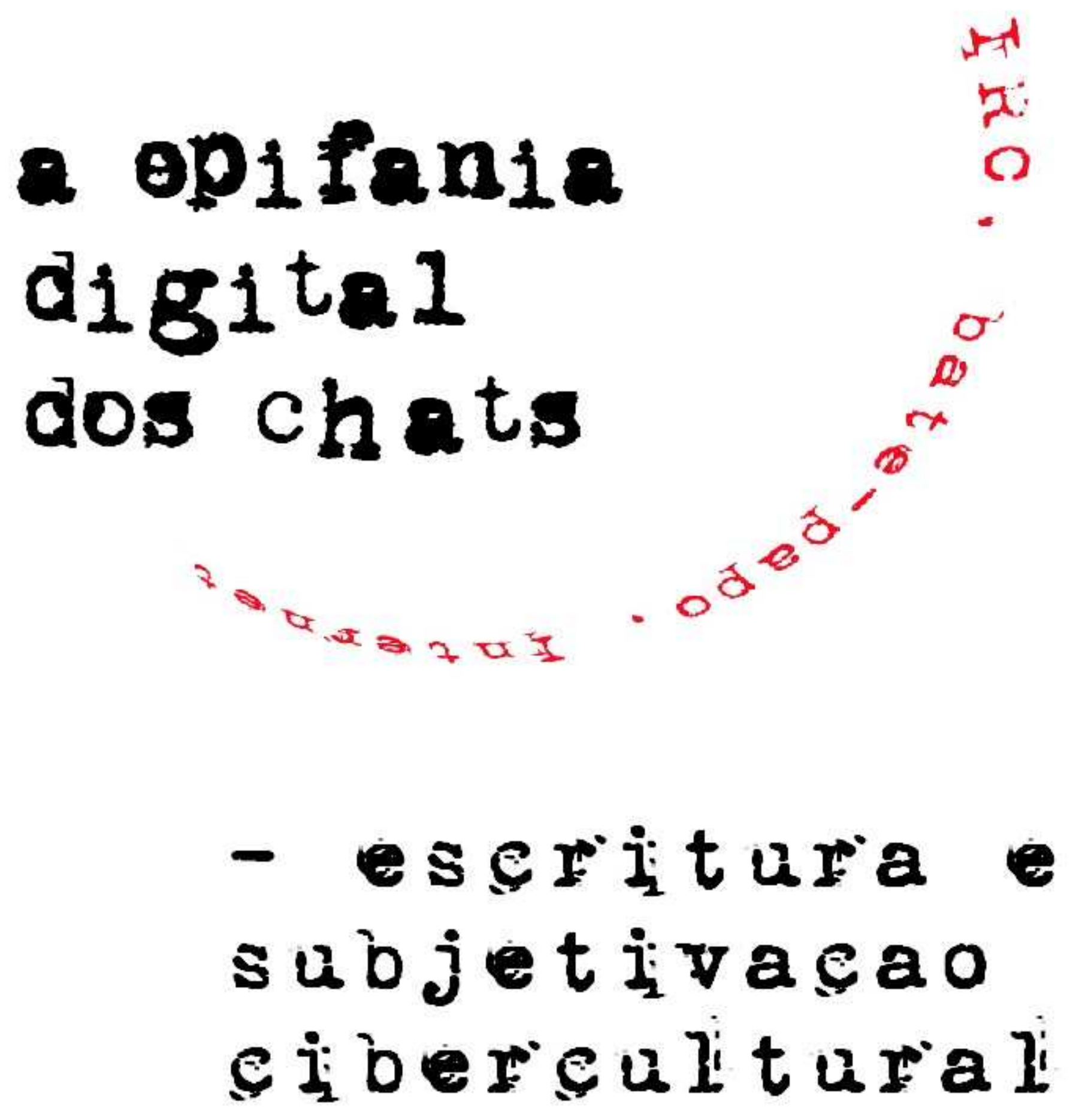

CFAO HACONDES FILHO (orientador) 


\section{A EPIFANIA DIGITAL DOS CHATS \\ - escritura e subjetivação cibercultural -}

Dissertação apresentada ao Departamento de Jornalismo e Editoração da Escola de Comunicações e Artes da Universidade de São Paulo, como exigência parcial para obtenção do título de Mestre em Ciências da Comunicação.

Orientador: Ciro Marcondes Filho

\section{ECA - USP}

\section{5}


UNIVERSIDADE DE SÃO PAULO

ESCOLA DE COMUNICAÇÕES E ARTES

Dissertação apresentada à Escola de Comunicações e Artes da Universidade de São Paulo como exigência parcial para a obtenção do título de Mestre em Ciências da Comunicação, dentro do Programa de Pós-Graduação em Ciências da Comunicação.

Departamento de Jornalismo e Editoração

Núcleo: Jornalismo e Cidadania

Orientador: Ciro Marcondes Filho

\section{BANCA EXAMINADORA}

Ciro Juvenal Rodrigues Marcondes Filho (orientador)

Elizabeth Nicolau Saad Corrêa (ECA-USP)

Eugênio Rondini Trivinho (PUC-SP) 
Aos meus pais 


\section{AGRADECIMENTOS}

Agradecimentos especiais para:

Meus pais, que ainda acreditam na importância da Universidade.

Ciro Marcondes Filho, meu orientador, por conjugar liberdade teórica e rigor conceitual, habilidades em franco processo de desaparecimento. Também por apoiar este trabalho irrestritamente, fornecendo o diálogo teórico que foi necessário.

FAPESP, Fundação de Amparo à Pesquisa do Estado de São Paulo, por fornecer os subsídios materiais que este trabalho demandou.

Nílson José Machado e Artur Matuck, que leram atentamente parte dessa pesquisa quando de sua qualificação.

Antonio Celso Ferreira, Áureo Busetto, Carlos Eduardo Jordão Machado, Dulcília Helena Schroeder Buitoni, Elizabeth Nicolau Saad Correa, Iara Lis Franco Schiavinatto Carvalho Souza, José Teixeira Coelho Netto, Juvenal Zanchetta Júnior, Milton Carlos Costa, Sérgio Augusto Queiróz Norte, Tania Regina de Luca e todos aqueles que foram meus professores ao longo dos anos.

Os colegas do Programa de Pós-Graduação em Ciências da Comunicação da ECA, todos eles, e especialmente aos integrantes do Núcleo de Jornalismo e Editoração e do Filocom: Alexandre Paza, Ana Elisa Antunes Viviani, Cristina Pontes Bonfiglioli, Danielle Naves de Oliveira, Eliany Salvatierra Machado, Fabio Botelho Josgrilberg, Mauro Celso Destácio, Paulo Roberto Masella Lopes, Ricardo Orlando e Tarcyane Cajueiro dos Santos.

Os nicks que conheci pelo ciberespaço afora, e que são a razão última do presente trabalho. Em especial para aqueles que revelaram o nome do seu mistério: Adriana Bicalho, Adriano Augusto, Alexey Dodsworth Magnavita, André Lopes, Augusto Jun Devegili, Daniel Pellizzari, Delfin, Diego Martins, Eduardo Perez, Eduardo Pinheiro, Everson Xerox, Felipe Cunha, Fernando Almeida, Fernanda Rahal, Giorgio Xenofonte, Gustavo Bitencourt, Heloísa Helena, Isaac Ache, Joana Coelho Lenz César, Luana Brasil, Marcio Seno, Mariana E. Messias, Maria Beatriz Meira, Nara Guimarães, Narjara, Omar Kaminski, Rafael Luíz Galdini Raimundo, Sabrina Castro, Thiago Marques, Thiago Balduzzi, Tatiana Rocha e Viviane Oliveira.

E a Paulo César Bontempi, que insistindo em contrariar o juízo universal de que funcionário público não trabalha, é responsável pela secretaria do Departamento de Jornalismo funcionar incompreensivelmente bem. 


\section{RESUMO}

A presente dissertação tem por objeto de análise os chats, as salas de bate-papo da Internet, de uma maneira algo diferenciada. Não se trata de cercar o objeto, mas de tentar alguma conversa com ele, de acompanhá-lo pelos bits afora. Grosso modo, este trabalho se divide em três partes principais ou capítulos.

O primeiro capítulo trata de pôr a nu a relação entre pesquisador e objeto, e parte de sua composição encontra-se redigida em primeira pessoa. A idéia é mostrar como o objeto se apresenta ao pesquisador. Ou, reformulando em termos teóricos, como o sujeito (categoria que não usaremos neste trabalho) pode se comportar frente às investidas furtivas do objeto. O excerto final deste capítulo, Modus Operandi, trata da questão metodológica que guiará todo o texto ora apresentado.

O segundo capítulo, onde as questões da subjetividade estão muito presentes, trata de mapear as mínimas unidades da cibercultura, seus personagens-bolha, e seu particular nomadismo na construção e desconstrução da tessitura social. Guerra, Controle, Terrorismo, são muitas as formas que a comunicação cibercultural toma e que não encontra uma tradução precisa antes da sociedade em rede. Isso quer dizer que as relações de poder também estão redesenhadas. Os dois últimos excertos deste capítulo procuram trabalhar como essas modalidades estranhas da comunicação espectral são vividas na contemporaneidade: como funcionam essas máquinas de subjetividade.

O terceiro e último capítulo prende-se majoritariamente à questão da escritura do medium. Trata-se de discutir uma vez mais, embora por outro veio, como essas unidades compõem o texto imaterial da vida em rede. O debate sobre a linguagem, a imaginação e a sedução de um texto que já é em si mesmo uma imagem é parte de uma discussão que a teoria da comunicação não pode mais se furtar. Não bastaria discutir apenas como uma nova subjetividade é gerada por essas modalidades comunicacionais, também é preciso identificar como tais modalidades criam toda uma nova lógica comunicacional, como o ciclo se fecha e, assim, cria realidade.

\section{ABSTRACT}

The present dissertation concerns Internet chat-rooms making an effort to work them with a different approach. It is not about surrounding the object but trying a kind of conversation with them. It is an attempt to pursue it across bits. Roughly speaking, this work is divided in three major chapters or sections:

The first chapter intends to clarify the relation between researcher and object embraced in this work. In fact, some parts of this chapter are written in first person. The point is to show how this object (chatrooms) comes to the researcher. In theoretical terms, it is to say how subject (a concept no longer used on this work) can represent itself with such a shifty object. The last extract on this chapter, Modus Operandi, is about the very methodological issue that guides this investigation.

It is on the second chapter that subjectiveness comes to surface. It is an attempt to map these little spots in cyberculture we call bubble-characters and also to point out their very nomad technique of doing and undoing culture. War, Control and Terrorism: electronic communication presents a vast amount of phenomena not clearly referred previous to this networking era. That means power has also been shaped in fresh new ways. The last two excerpts of this chapter concerns this strange modality in spectral communication. It is about how these subjectivity machines work on contemporaneity.

The third and last chapter is mostly about the writing style this medium brings on. Once again, the aim is to discuss how this intangible and networked text turns to be composed by small clusters called nicks. It is focused on language, imagination, and a seduction of the text which is an image itself. These are all questions theory of communication can no longer evade. However, it is not enough to just discuss how interactivity on Internet creates new subjectivity. It is also important to identify how these interactions create a new logic of communication conspicuously innovative. It is mandatory to identify how this feedback circuit works thus creating reality. 


\section{A EPIFANIA DIGITAL DOS CHATS \\ ESCRITURA E SUBJETIVAÇÃO CIBERCULTURAL}

LOGIN: Guia prático para uma existência virtual

pág.007

\section{Capítulo 1.0}

1. Recônditos da subjetividade

pág.011

2. Epifania figital

pág.016

3. Ciber carne moída

pág.020

4. Modus operandi

\section{Capítulo 2.0}

1. Máquinas de guerra e controle do ciberespaço

pág.034

2. Táticas de terrorismo conversacional

3. Édipo e maquinismo Esquizo

4. O buraco negro da descentralização

\section{Capítulo 3.0}

1. A sedução do texto estranho

2. Fantasia: um bate-papo comigo mesmo (ou com ninguém)

3. Emergência linguiística

4. Linguagem carne cor de plástico 


\section{GUIA PRÁTICO PARA UMA EXISTÊNCIA VIRTUAL}

O chat é uma peculiar ferramenta que tem despertado interesse nos pesquisadores do ciberespaço. Tratase de um serviço de comunicação existente em duas modalidades: pela WW, bastando um navegador padrão e sem necessidade de software especial (por isso chamado de webchat); ou por meio de um programa que acessa um servidor de chat, sendo necessário que este programa cliente esteja instalado. Esta segunda modalidade chama-se IRC (Internet Relay Chat) e seu programa de acesso, IRC Client ${ }^{1}$.

Nas duas modalidades o usuário precisa estar conectado à rede e escolher um servidor. Escolhe-se um apelido (nickname) e então se pode entrar (login) nas salas de conversa. Nos webchats, a entrada é automática, uma vez que não há necessidade de configuração alguma. No IRC, uma vez conectado à rede, o usuário precisa ter o cliente instalado e configurado (ver figura 1 e 2) para então ter acesso à lista de canais e começar a participar. As salas de chat $^{2}$ podem abarcar potencialmente todos os temas, sendo classificadas por idade, cidade, atualidades, sexo, informática, música e assim por diante (ver figura 3).

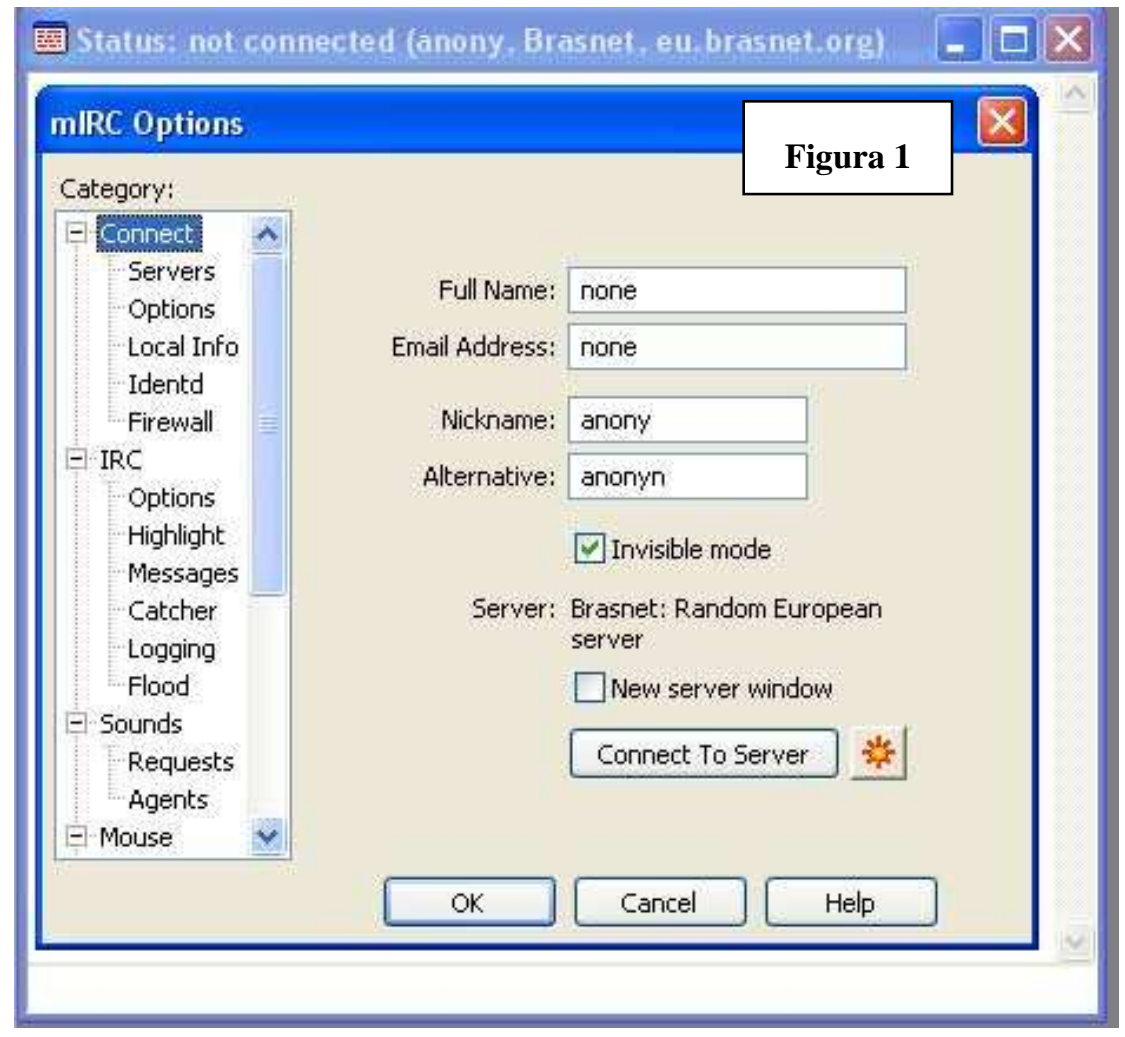

O propósito único de um chat é fazer com que seus usuários conversem, interajam. Não importa se duas ou uma infinidade de usuários, o importante é a troca de mensagens sincronicamente ${ }^{3}$, em tempo real.

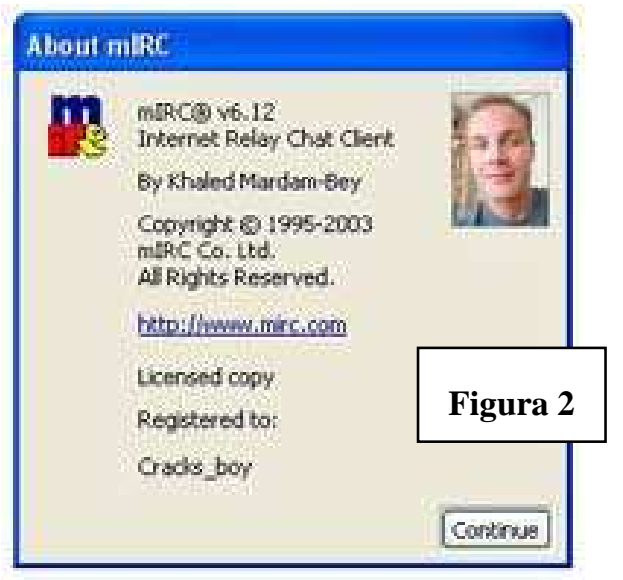

Este estudo trata do IRC, que é um sistema de troca simultânea via texto e que requer um programa específico (client) para seu uso, sendo o mais comum deles ainda o $\mathrm{mIRC}^{4}$. Além de ser mais rápido e funcional, a escolha do IRC foi feita também pelos recursos disponíveis de registro das conversas, que podem ficar gravadas em arquivos de texto (arquivos com terminação log, por isso chamados de Logs) 
Figura 3

O programa funciona de forma relativamente simples. Uma vez instalado e configurado o software, o usuário pode conectar a um servidor de IRC que ficará repassando as informações da rede na janela Status, conforme mostra a figura 4 . Podese abrir uma infinidade de janelas sendo cada uma delas referente a um canal (precedidos do símbolo "\#" - ver

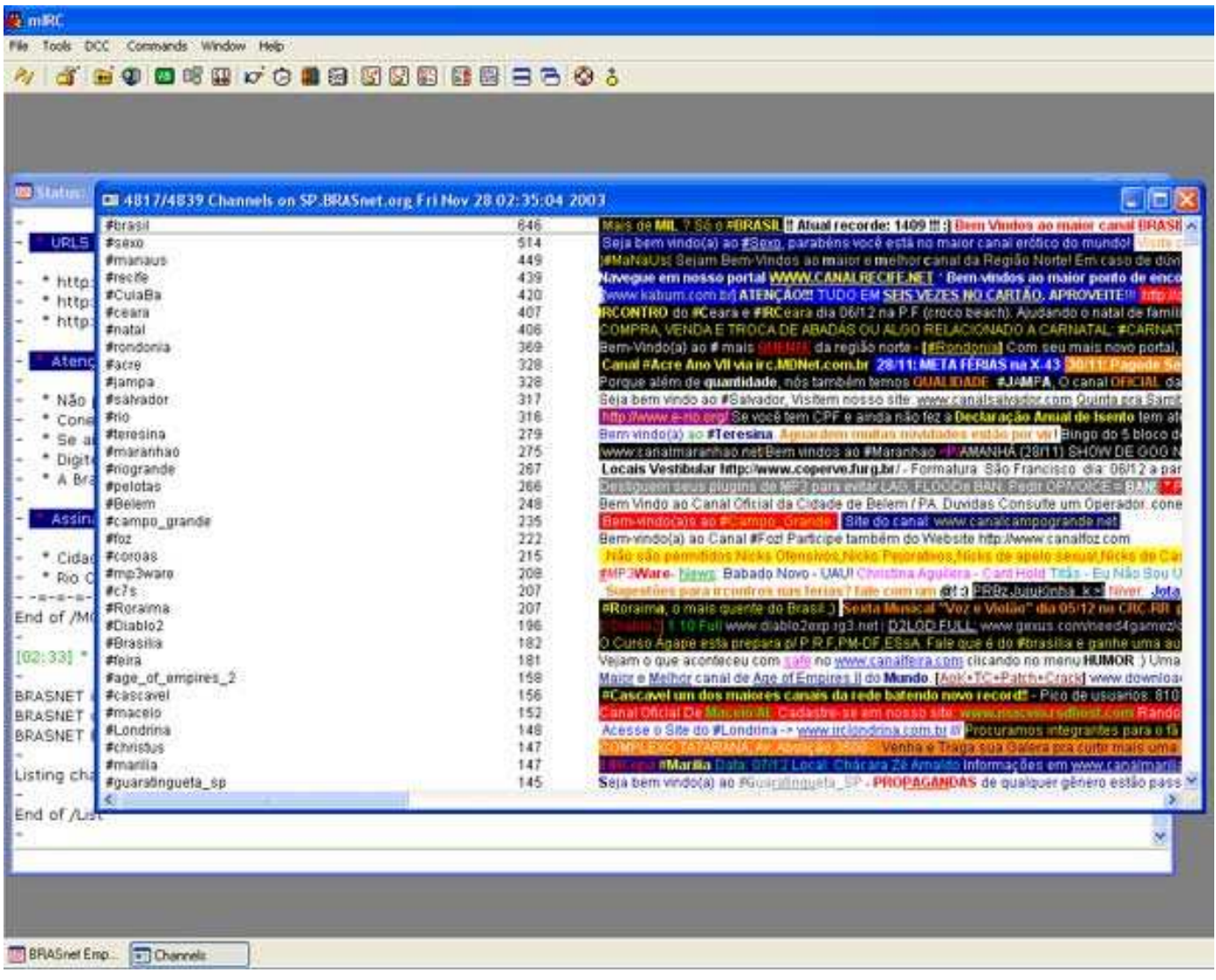

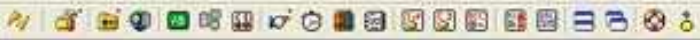

figura 5$)^{5}$, ou uma conversa privada (pvt - ver figura 6$)^{6}$, conforme o usuário deseje. À direita da janela encontram-se todos os usuários presentes naquele canal. A parte inferior de cada janela é feita de um campo onde se digita o texto. Conforme terminadas as frases e pressionando a tecla "enter" (enviar), as

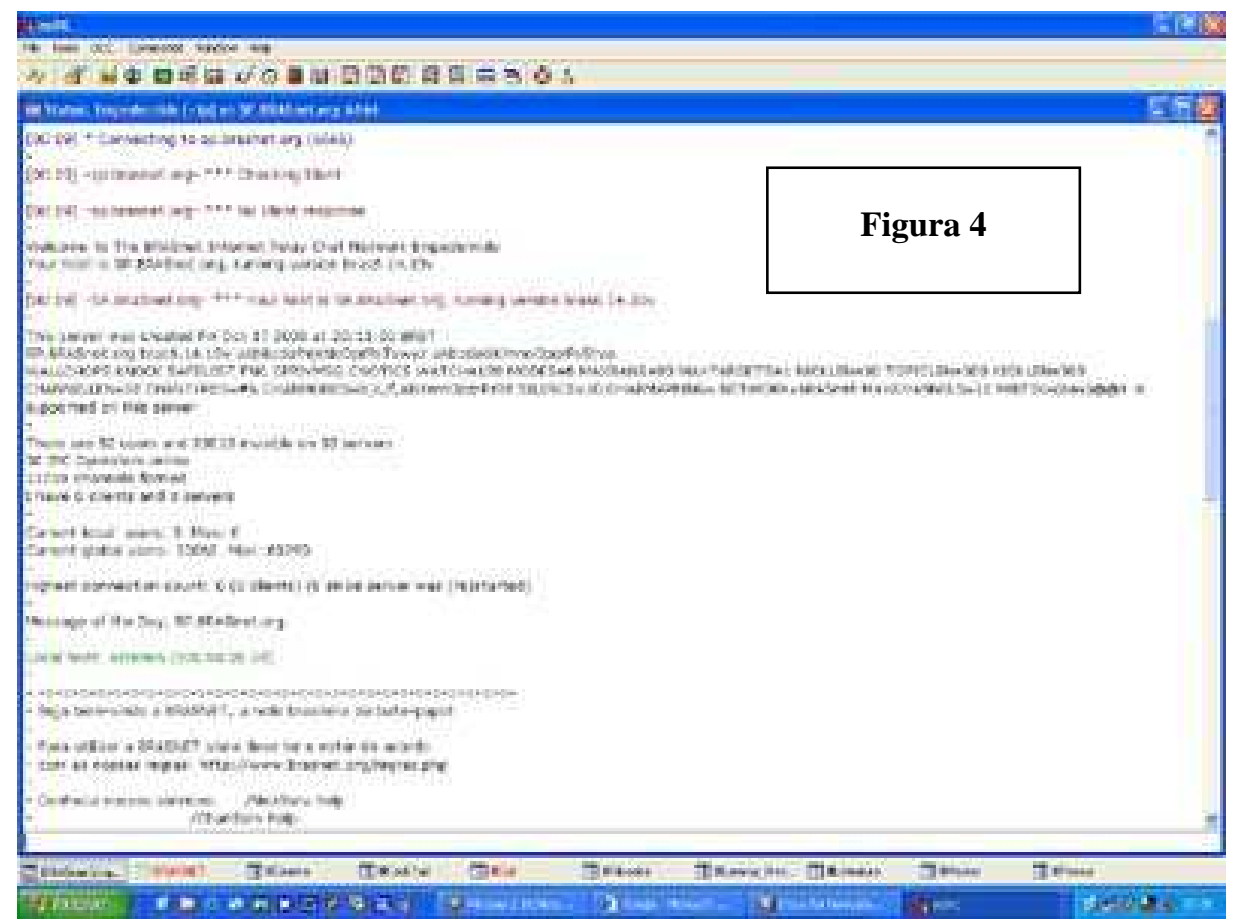

mensagens vão aparecendo na janela principal antecedidas do usuário (nick) que a digitou. Todos lêem todos, havendo a possibilidade de ignorar usuários caso necessário. As mensagens são alocadas respeitando a ordem na qual foram enviadas e subindo tela acima automaticamente. Também é possível iniciar conversas privadas entre os usuários, basta clicar com o mouse no nick em questão. 



\section{NOTAS}

${ }^{1}$ As origens do IRC datam de 1988, quando Jarkko Oikarinen do Departamento de Ciências e Processos Informáticos da Universidade de Oulu, na Finlândia, criou o Internet Relay Chat. O objetivo era desenvolver um programa de comunicação que permitisse aos usuários da BBS de Oulu (administrada pelo seu departamento) ter discussões nos moldes da Usenet, então padrão para listas de discussão, mas em tempo real. Jukka Pihl desenvolveu então um programa, o MUT (MultiUser Talk), que ainda não permitia a função de canais seriados, característica essencial dos chats tomada de empréstimo do rádioamadorismo. Os canais foram provavelmente a invenção mais inovadora e interessante, pois permitiu que muitos usuários adentrassem à mesma discussão ao mesmo tempo em que participavam de discussões diversas. A partir de 1989, Okarinen convence amigos de outras Universidades da Finlândia e Suécia a instalarem o programa servidor de IRC nos computadores conectados à rede finlandesa. Paulatinamente, outras Universidades também começaram a usar o IRC, expandindo-se rapidamente. Foram Jeff Trim, (Universidade de Denver), David Bleckman e Todd Ferguson (Universidade do Estado de Oregon) os pioneiros a instalarem os primeiros servidores IRC fora da Escandinávia. Não se imaginava, então, que o IRC cresceria tão rapidamente, adquirindo escala global. Durante a primeira guerra do Golfo, em 1991, usuários de diferentes países conectavam-se ao IRC para obter informações sobre a guerra. O IRC funcionou como canal para os habitantes do Kuwait contarem o que vinha acontecendo no país sob invasão Iraquiana. Neste período o IRC conheceu sua maior expansão, tornando-se um dos serviços da Internet mais requisitados. Assim como a Internet e boa parcela de sua tecnologia, o protocolo de transferência do IRC não tem copyright, o que viabilizou sua difusão em massa entre os estudantes que, em seu constante aperfeiçoamento, fizeram desta interface um de seus media preferidos. No Brasil, entretanto, por conta da Lei de Reserva de Marcado (que impossibilitou a importação de Hardware), somada a uma legislação draconiana para as telecomunicações, a Internet e assim o IRC demoraram a chegar. A abertura comercial só se deu em 1996; antes, o acesso só era possível para universitários, pesquisadores e profissionais que trabalhassem diretamente com o meio. Para mais detalhes, ver: La fantasía y los afectos en el chat. IN: Sánchez, Antulio. La era de los afectos en internet. México: Editorial Océano, 1997.

2 "Muito mais dinâmicas do que os e-mails são as salas de chat, bate-papos grupais, nas quais se pode conversar ao digitar os comentários e ver as respostas dos outros participantes na tela. Na verdade, não há uma sala, mas um programa que traz os participantes para uma conversa e, de uma maneira abstrata, realiza a função básica de uma sala. Por isso é irresistível se dizer que esse programa constrói uma sala virtual.” Santaella, Lucia. Culturas e artes do pós-humano - da cultura das mídias à cibercultura. São Paulo: Paulus, 2003. (p.118).

${ }^{3}$ Por serviços síncronos entende-se aqueles em que os usuários conectados trocam mensagens "em tempo real”, ou seja, ao mesmo tempo em que se envia também se lê. Nos serviços assíncronos, por sua vez, os usuários não precisam estar simultaneamente conectados, pois as mensagens são enviadas e recebidas em diferentes momentos. Os serviços síncronos da Internet, baseados em texto são, entre outros: IRC (Internet Relay Chat), Pessoa a pessoa (Talk), MUDs/MOOs, Webchat, ICQ (acrônimo de I seek you), AOL/UOL e Microsoft (MSN) Messenger e demais programas de mensagens instantâneas. Há também os serviços multimídia que fazem uso de imagens, sons e demais dispositivos gráficos. Os serviços de interação assíncronos são o Correio Eletrônico (e-mail), as Listas de Discussão e Newsgroup, Fóruns, USENET, Blogs, Ferramentas diversas para postagem na Web, dentre outros.

${ }^{4}$ mIRC é um Internet Relay Chat Client, desenvolvido por Khaled Mardam-Bey e disponível em www.mirc.co.uk. Sua fácil usabilidade, somada ao fato de ser desenhado para plataforma Windows, o transformou no principal cliente de IRC. "Cliente de IRC" é o software que possibilita conversar simultaneamente com diversas pessoas, ou apenas acompanhar a conversa que se desenvolve. A interface do mIRC é relativamente simples, contendo uma janela maior onde a conversa se desenrola e uma menor, à direita, com a lista de todos os participantes daquele canal. Pode-se clicar com o mouse em qualquer usuário da lista, abrindo-se então uma conversa (que pode ser aceita ou não) privativa e não acessível aos demais usuários. Quanto à janela principal do canal, a da esquerda, ela deposita as contribuições de cada usuário de maneira sucessiva, onde cada frase é precedida pelo nick que a digitou, de maneira que se possa identificar os autores. Essa janela também indica a movimentação dos usuários que entram e saem do canal. Pode-se participar de vários canais ao mesmo tempo, bastando para tanto gerenciar as janelas de cada um. Quando se requisita a lista de canais do servidor, eles aparecem precedidos do símbolo "\#”, que significa, naturalmente, "canal".

${ }^{5}$ Os canais costumam ser freqüentados por um público grande e estável. Os canais existem em ambas as modalidades de batepapo, isto é, tanto no IRC quanto nos webchats dos principais portais brasileiros, como o UOL (Universo OnLine do grupo Folha de São Paulo/Abril) ou o Terra (grupo Telefonica).

${ }^{6} P v t$, do inglês private, é uma forma de conversa particular possibilitada pelo programa, ou seja, os usuários têm a possibilidade de conversar dois a dois, independentemente das conversas nos canais. No $p v t$ as mensagens passam pelo servidor de IRC para chegar ao destinatário, enquanto que na modalidade DCC (Direct client-client) a conexão é (P2P), ou seja, feita ponto a ponto (peer to peer). 


\section{RECÔNDITOS DA SUBJETIVIDADE}

O projeto Moderno foi muitas vezes resumido na máxima que o define como controle e manipulação do espaço físico (ordem industrial), em contraposição ao projeto pós-moderno, que seria definido por um processo de desmaterialização destes espaços (conseqüência da ordem tecnológica). Essa contraposição visa indicar que a criação dos não-lugares contemporâneos encontra-se intimamente ligada com a destruição do espaço moderno. Eletrônica e informática, picos da curva tecnológica, forjaram o ciberespaço que bem pode ser caracterizado como o lustroso acabamento desse processo de destruição.

Alguns aspectos desse movimento são auto-evidentes. No espectro econômico e trabalhista, a transformações nas relações de trabalho são conhecidas, em especial a ameaça ao emprego formal como modelo de contrato estruturante da economia, que abriu campo para a crescente informalidade e terceirização de serviços. No campo político, a posição delicada e incerta do Estado-nação é outra recorrente constatação dos efeitos globalizantes. Em ambas as esferas - econômica e política - há um inequívoco componente: fim do emprego formal (desemprego) e aumento da produtividade, ambos causados pelo emprego massivo de tecnologias.

No espectro cultural, os fatores que se fazem visíveis nesse rearranjo social são mais complexos e desafiadores. Um das inequívocas novidades no cenário mundial do capitalismo ocidental é a crescente massificação do entretenimento e do consumo, tipificada pela produção de gadgets a baixíssimo custo em economias em crescimento, como a China e os tigres asiáticos. A fisionomia da relação de produção e consumo perdeu seus traços mais conhecidos, e alterando-se, provocou uma relação entre o trabalho e consumo diferenciada, onde muitas vezes o princípio de lugar de trabalho e lugar de lazer desaparece. $\mathrm{O}$ entretenimento, por sua vez, é generalizado.

Esse processo de delineamentos e reorganizações não se desata da técnica, tanto em seus métodos quanto em seu destino. O descobrimento de um, em termos heideggarianos, é a elucidação do outro. A tecnologia, artifício essencial de tais transformações, demanda a compreensão e a reflexão sobre estes bytes, mergulhando no intricado movimento do ciberespaço, ecossistema do possível e do impossível mundo tecnológico.

Do ponto de vista das ciências sociais, a fratura é evidente. Conceitos fundamentais como Estado-nação, localidade, território, classe, e toda uma miríade de ferramentas que serviam para entender as relações sociais, começam a se mostrar insuficientes diante de certos objetos, de certas manifestações. Metodologicamente, o problema é complexo e tenso, mas não se pode perder de vista que os conceitos das ciências sociais são históricos e, mudá-los, não é só uma possibilidade. É antes um imperativo. 
Arriscar novos conceitos para compreender a sociedade, desenvolvendo assim um outro método, são riscos que pecam, acima de tudo, pela ambição. Poder-se-ia dizer pretensão mesmo. Infelizmente, uma análise que tenha por objetivo as manifestações novas e não prescritas na exegese teórica deve fazer uso da criatividade estética que um trabalho sobre a Era Tecnológica exige. Quando o objeto é provocador, o escopo teórico de uma pesquisa também deve saber provocar.

Se observarmos essas agitações do alto do projeto moderno, o bolo desandou. A implosão dos espaços modernos (sobretudo públicos) e o aparecimento dos não-lugares ${ }^{1}$ fizeram emergir os modos de vida mais inexplicáveis ao flâneur; sendo agora fractalizados, espectralizados. Isso porque a criação destes não-lugares produz estranhas formas de sociabilidade: às cidades não mais o saudável passeio, mas o zapping esquizofrênico e sem referencial; ao universo virtual e sua cultura, o deleite de uma identidade que é predominantemente fluxo. Esse novo agente, o zapeador, carece de uma identidade solidamente definida, imergindo na amplitude de intercâmbios virtuais, sempre expansíveis. Intensidade, velocidade, descontinuidade e fragmentação, além de outros conceitos que tentam enquadrar a nova subjetividade contemporânea, gravitam em torno da prática do zapping, dessa identidade essencialmente apátrida.

O zapeador é o produto último do sujeito que não existe mais. Perambulando pelos enigmáticos espaços da cibercultura, vivencia os bits, informação imaterial. Seus encontros e trocas, subjetivas e imateriais, se processam normalmente. No mais, herdamos uma situação paradoxal: lugares de não-sociabilidade e não-lugares de sociabilidade. Falamos que é um sujeito que não existe porque sua unidade, autonomia e isolamento - características da sua centralização, são substituídas por um coletivo digital e dispersivo, interconectado e nômade. Nenhuma categoria de sujeito sobrevive aqui.

O virtual adquiriu uma espécie de transcendência em relação à sociedade que pretende informar ou representar. Trata-se de um tipo de campo que se desenvolveu por si mesmo. Podemos encará-lo como uma patologia, mas ele é, antes de tudo, uma excrescência, um fenômeno total, conforme a expressão de Marcel Mauss, e sobre o qual não existe mais possibilidade de intervir enquanto sujeito. Só podemos entrar nesse terreno na condição de objetos. Quem for capaz de produzir acontecimentos dentro dessa lógica, faz parte do jogo. Não há alternativa de interação. É impossível participar como sujeito tendo algo a dizer que não esteja inscrito na dinâmica do objeto aceito. $^{2}$

Os chats surgem aqui como um fenômeno do descentramento. Relato:

Eu fragmento minha mente. Estou ficando cada vez melhor nisso. Posso me ver como sendo duas, três ou mais pessoas. Eu apenas ligo uma parte da minha mente, e depois outra, conforme passo de uma janela para outra. A realidade parece apenas mais uma janela, e não é necessariamente a melhor delas. ${ }^{3}$ 
Ao ler uma sala de chat, imediatamente se observa um campo de batalha de desejo. São usuários praticamente indefiníveis. $\mathrm{O}$ nickname (apelido do usuário) protege a identidade do indivíduo, em meio a uma nebulosa massa de nicks orquestrando um balet de expressões incompreensíveis. Demora um tempo para se acostumar. A ordem é uma desordem permanente.
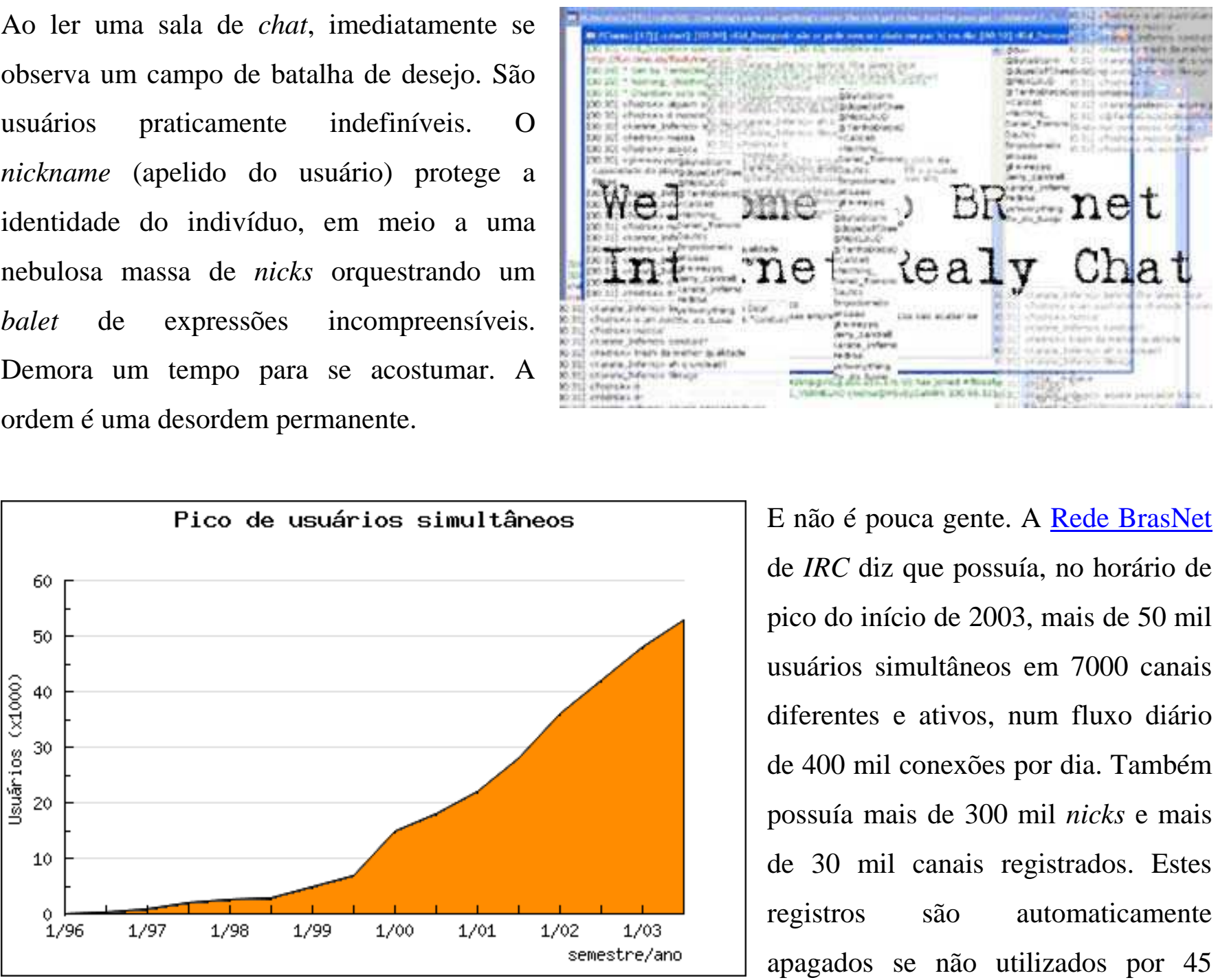

E não é pouca gente. A Rede BrasNet de IRC diz que possuía, no horário de pico do início de 2003, mais de 50 mil usuários simultâneos em 7000 canais diferentes e ativos, num fluxo diário de 400 mil conexões por dia. Também possuía mais de 300 mil nicks e mais de 30 mil canais registrados. Estes registros são automaticamente apagados se não utilizados por 45 dias, no caso dos nicks, e 14 dias, no caso dos canais. De acordo com pesquisa do IBOPE, os usuários de bate-papo são tipicamente medium users e heavy users, os quais correspondem à cerca de $80 \%$ dos internautas brasileiros, e que em sua maioria (84\%) estão entre as classes A e B. Pelas estatísticas da própria BrasNet, constatou-se que $83 \%$ dos usuários permanecem conectados até 1 hora na rede e $12 \%$ até 2 horas, o que demonstra uma alta rotatividade de usuários, gerando mais de 400 mil "hits" diários, distribuídos pelos diversos servidores conectados. Seus usuários são predominantemente adolescentes $(50,3 \%)$ e jovens $(39,8 \%) ; 29,1 \%$ cursam o segundo grau, $19,7 \%$ tem o segundo grau completo e $22,4 \%$ cursam o terceiro grau. Surpreendentemente as regiões apresentam grande equilíbrio na distribuição de usuários, sobressaindo a região Nordeste com $34,6 \%{ }^{4}$.

A BRASnet, uma rede brasileira de bate-papo, foi a fonte dos relatos, conversas, diálogos e textos presentes neste trabalho. É a maior rede de IRC do país, mas não a única. O gráfico abaixo ${ }^{5}$ traça uma comparação entre os 25 maiores servidores de bate-papo do mundo. A BRASnet figura em sexto lugar e a BRASirc, também brasileira, em $12^{\circ}$ entre os maiores. O critério de classificação é o número absoluto de usuários em um mês, neste caso, o mês de novembro de 2002. Além do número de usuários, também 
consta no gráfico o número de servidores que constituem a rede e número de canais, categorias essas que são então subdivididas em três: número máximo alcançado no dia anterior (19/12/2002), média e, por fim, recorde alcançado no mês precedente. Naturalmente, estes números crescem continuamente ${ }^{6}$.

\begin{tabular}{|c|c|c|c|c|c|c|c|c|c|c|c|c|c|c|c|}
\hline \multicolumn{2}{|c|}{ positions } & \multirow[b]{2}{*}{ network } & \multicolumn{3}{|c|}{ servers } & \multicolumn{3}{|c|}{ users } & \multicolumn{3}{|c|}{ channels } & \multirow[b]{2}{*}{ ups } & \multirow[b]{2}{*}{ time $(g m t)$} & \multirow{2}{*}{\multicolumn{2}{|c|}{ status }} \\
\hline now & last & & yes & and & top & yes & ang & top & ves & ang & top & & & & \\
\hline 1. & 1. & QuakeNet & 49 & 48 & 50 & 136524 & 144371 & 153279 & 128083 & 124613 & 130054 & 2786 & $19: 08$ & 0124 & \\
\hline 2. & 2. & Undernet & 39 & 85 & $3 \pi$ & 117561 & 117766 & 126565 & 43518 & 43057 & 43730 & 3177 & $21: 10$ & $1 / 25$ & s \\
\hline 3. & 3. & IRCnet & 54 & 52 & 55 & 116356 & 120129 & 124253 & 52668 & 53607 & 55451 & 2154 & $21: 05$ & $1 / 27$ & I \\
\hline 4. & 4. & EFnet & 53 & 52 & 54 & 110091 & 111434 & 115794 & 41068 & 40530 & 41603 & 2077 & $21: 03$ & $0 / 24$ & \\
\hline 5. & 5. & DALnet & 20 & 20 & 23 & 79918 & 81010 & 97499 & 31002 & 32067 & 35775 & 3995 & $16: 02$ & $1 / 25$ & \\
\hline 6. & 6. & BRASnet & 39 & 38 & 40 & 39026 & 34934 & 47548 & 12149 & 11232 & 13581 & 1000 & 03:01 & $0 / 24$ & \\
\hline 7. & 7. & IRC-Hispano & 41 & 40 & 41 & 31926 & 34379 & 39003 & 21999 & 22126 & 23441 & 778 & $22: 05$ & $4 / 28$ & \\
\hline 8. & 8. & GamesNET & 20 & 21 & 22 & 27937 & 28393 & 31285 & 24827 & 24093 & 34827 & 1396 & $02: 04$ & $0 / 24$ & m \\
\hline 9. & 9. & Webchat & 10 & 10 & 12 & 30094 & 27875 & 30758 & 10935 & 10268 & 11135 & 3009 & $15: 12$ & 2126 & 1 \\
\hline 10. & 10. & PTnet & 60 & 55 & 61 & 24049 & 23183 & 29583 & 14251 & 13562 & 15803 & 400 & $00: 08$ & $11 / 35$ & \\
\hline 11. & 11. & GalaxyNet & 32 & 30 & 32 & 24259 & 23925 & 25914 & 17033 & 46820 & 17154 & 758 & $16: 04$ & $3 / 27$ & \\
\hline 12. & 12 & BrasIRC & 45 & 43 & 47 & 16494 & 13200 & 19458 & 5458 & 4811 & 6019 & 366 & 03:01 & 2126 & \\
\hline 13. & 13. & Voila & TE & 14 & 10 & 17947 & 17301 & 18594 & 5514 & 4614 & 5662 & 1121 & $21: 10$ & 0124 & \\
\hline 14. & 14. & EnterTheGame & 8 & 8 & 8 & 14049 & 14228 & 14968 & 9046 & 9157 & 9367 & 1756 & $03: 03$ & $8 / 31$ & \\
\hline 15. & 15. & UniBg & 38 & 37 & 38 & 11558 & 12112 & 13387 & 7450 & 6900 & 8272 & 304 & $20: 10$ & $6 / 30$ & \\
\hline 16. & 16. & HanIRC.org & 21 & 21 & 23. & 12117 & 11854 & 13362 & 7161 & 6993 & 7296 & 577 & $14: 04$ & $14 / 35$ & \\
\hline 17. & 17. & AustNet & 18 & 20 & 22 & 8822 & 9872 & 11955 & 4923 & 5058 & 5369 & 490 & $12: 02$ & $11 / 35$ & $\mathrm{~m}$ \\
\hline 18. & 18. & criten & 18 & 18 & 21 & 10783 & 9545 & 11878 & 930 & 858 & 1035 & 599 & $11: 02$ & $9 / 33$ & \\
\hline 19. & 19. & IrCQ-Net & 7 & 5 & 7 & 3895 & 5257 & 10994 & 1411 & 1678 & 4381 & 556 & $23: 05$ & $1 5 \longdiv { 4 3 }$ & \\
\hline 20. & 20 & Aniverse & 3. & 3 & 3 & 9901 & 9795 & 10494 & 2160 & 4902 & 2168 & 3300 & $00: 00$ & 0124 & 1 \\
\hline 21. & 21. & Aitvaras & 11 & 10 & 11 & 8272 & 8849 & 9788 & 6340 & 6371 & 6815 & 752 & $20: 00$ & 0124 & \\
\hline 22. & 22. & freenode & 24 & 28 & 24. & 8532 & 8932 & 9437 & 3260 & 3184 & 3379 & 355 & $21: 12$ & $0 / 24$ & \\
\hline 23. & 23. & Rizon & 16 & 12 & 16 & 7320 & 5110 & 8143 & 593 & 342 & 593 & 457 & $19: 09$ & 2126 & I \\
\hline 24. & 24 & Terra & 0 & 3 & 8 & 0 & 2966 & 7396 & 0 & 1029 & 2608 & - & $23: 14$ & $72 / 72$ & ms \\
\hline 25. & 25. & InTrac & 17 & 13 & 17 & 6326 & 4820 & 6963 & 539 & 385 & 593 & 372 & $17: 06$ & $18 / 40$ & \\
\hline
\end{tabular}

yes: yesterday's top value

avg: average top value (last 30 days)

top: top value (last 30 days)

ups: users per sener c: no list of channels

m: no message of the day

s: no list of severs

h / l: no homepage / logo

O estudo que segue é uma tentativa, algo canhestra, de mapear esses dados. Mas mapear aqui tem outro sentido, com aliás muito do método proposto. Esperamos que parte desta proposta possa ficar mais clara ao longo do percurso. 


\section{NOTAS}

${ }^{1}$ Um não lugar é definido pela não-permanência, pela transitoriedade. São os locais de passagem, onde as pessoas estão de corpo presente, mas não de espírito. Assim são os meios de transporte, as modernas avenidas, e todo lugar de não-vivência, de passagem, sem memória nem sociabilidade. "Por inspiração em Walter Benjamin, poder-se-ia até dizer, com o risco de toda liberdade de figuração, que, com o advento e desenvolvimento das redes comunicacionais, o continente natural e urbano perdeu completamente sua aura, isto é, a dimensão caracterizada pelo hic et nunc, o aqui e agora, que lhe conferia o caráter de coisa única no tempo e no espaço e, com isso, lhe garantia a autenticidade e a autoridade histórica como original.” Trivinho, Eugênio Rondini. Cyberspace: Crítica da Nova Comunicação. Tese de Doutorado, ECA-USP, 1999. Para uma melhor compreensão do tema, sobretudo pela perspectiva conceitual proposta por Marc Augé, ver Beltrina da Corte Pereira, São Paulo: Cidade misturada/cidade inconclusa zapeando a metrópole metalizada. Tese de Doutorado, ECA-USP, 1997.

${ }^{2}$ Baudrillard, Jean. Entrevista feita por Juremir Machado da Silva. Jornal Folha de São Paulo, Ilustrada, 25/11/1998. Versão integral em http://www.pucrs.br/famecos/10-4.html

${ }^{3}$ Comentário de um aluno de pós-graduação em administração do Dartmouth College, usuário dos antigos MUDs (Multi User Dungeon/Domains). Turkle, Sherry. Identidade na Internet. IN: Brockman, John (org.). As coisas são assim. São Paulo: Cia das Letras, 1997. Vale registrar que o sistema Time-sharing foi desenvolvido e aperfeiçoado no Dartmouth College. O sistema de organização e distribuição de tarefas utilizado anteriormente era o batch processing (processamento em lote). Ver a respeito: Kemeny, John G. Homem e Computador. Rio de Janeiro, Cia Gráfica Lux, 1974.

${ }^{4}$ Dados disponíveis em: http://www.brasnet.org/conteudo.php?id=492. Desses dados pode-se ler muitas coisas, dentre as principais, o óbvio: O meio é ainda demasiado elitizado, o que é diretamente condicionado pelo alto custo da informatização.

${ }^{5}$ Networks of the Internet Relay Chat. The charts positions 1st - 425th. Disponível em: http://irc.netsplit.de/networks/

${ }^{6}$ Segundo a pesquisa da Nazca \& Saatchi, de 1998, depois dos mecanismos de busca e do e-mail, é o chat o serviço mais procurado pelos internautas. A pesquisa diz que pelo menos um quarto de todo o tempo de conexão é dedicado aos canais de bate-papos da rede. Ver: Marrito, Michel. Todo mundo quiere charlar. Interfase, México: Reforma, 20/07/1998. Outro estudo da mesma Nazca \& Saatchi, de outubro de 1999, indica que os chats são usados por 15\% dos usuários no mundo. Em mais um estudo, desta vez efetuado pela mexicana NetValue, indica-se que $25 \%$ dos internautas são usuários dos chats. Internautas mexicanos son chateadores. 26/11/2000. Disponível em: http://www.latamnews.com/netvalue 121000.html. Outra pesquisa mexicana diz que $30 \%$ dos usuários deste país usam tal meio, enquanto que outros 35\% estão dispostos a começar a fazê-lo. López, Luis Enrique. Hábitos culturales y medios del nuevo milenio. México: Reforma, 20/03/2000. 


\section{EPIFANIA DIGITAL}

Epifania:

Apreensão intuitiva da realidade por meio de algo geralmente simples e inesperado (como um lugar-comum ou uma pessoa vulgar) Ex.: no percurso do seu trabalho, Joyce foi das coisas à sua epifania.

A representação literária de uma epifania.

Trabalho, ou parte dele, simbolicamente revelador.

Aparecimento ou manifestação reveladora de Deus ou de uma

divindade.

Manifestação ou percepção da natureza ou do significado essencial de uma coisa.

Sinônimos: adoração, personificação, representação.

Etimologia: gr. epipháneia, as 'aparição, manifestação', pelo latim epiphanía, ae 'aparição, manifestação de Jesus aos Reis Magos'; $f$. hist. Séc. XV epiphania, séc. XV epyphania.

Dicionário Houaiss da Língua Portuguesa ${ }^{1}$

Então o leitor é aquele que disentangles e re-embodies: ao fazer ressoar dois objetos, ele produz epifania, extraindo a imagem preciosa das condições naturais que a determinam, para reencarná-la nas condições artísticas escolhidas

Gilles Deleuze ${ }^{2}$

Epifania porque evocação. Tomar um objeto técnico como microuniverso evocador da condição digital na Era Tecnológica. Assim, quando falamos em epifania não queremos com isso remontar a uma eventual interioridade do pesquisador, mas ao feixe de sentido que passa do objeto ao pesquisador, e volta, e vai.

A pesquisa que segue procura debater os sistemas de comunicação on-line (chat rooms/salas de batepapo) concebidos como uma epifania para a Teoria da Comunicação, espécie de provocação, que pode virtualmente expressar algumas das novas manifestação contemporâneas, tanto no respeitante às identidades (macro manifestações), quanto no respeitante ao estilo e ao desejo (micro manifestações).

Entender os chats como um objeto rico em elementos evocadores requer que tal trabalho seja arbitrariamente teórico. Embora o expediente de se trabalhar com as conversas registradas no meio assim como análises, comentários e artigos versando sobre o assunto - tenha sido bastante utilizado, trata-se de um trabalho em que a reflexão sobre o objeto, mais do que exame pormenorizado sobre a ferramenta, funciona como fio condutor por todo o texto. 
Assim, há capítulos em que impera a discussão teórica. Naturalmente, também há capítulos analíticos e discussões que procuram trabalhar a especificidade do medium, quer no aspecto lingüístico, quer no aspecto eminentemente tecnológico. Entretanto, como ficará claro no capítulo Modus Operandi, a forma como trabalhamos as disjunções entre o objeto e suas evocações de sentido apresenta uma série de peculiaridades. São estranhezas necessárias à abordagem, metodologicamente e estilisticamente. É um estilo-método.

Isso quer dizer que procurei, ao longo da última década em que tive contato com o meio ${ }^{3}$, uma forma de retratá-lo que pudesse trazer para dentro da abordagem acadêmica, hermética e estática, alguns dos aspectos multiaxiais e mesmo parte da vivacidade do meio. Deleuze surgiu a mim não apenas como uma proposta sedutora e muitas vezes brilhante, fora uma proposta inevitável.

Funciona, mais ou menos, assim:

Um nick com nome de escritor abre uma conversa privada com outra máscara de escritor. Pergunta se escreve por hábito e recebe como resposta um "Não, por obrigação. Odeio escrever. Se pudesse, não escreveria." Diz que achou as palavras bonitas, ao que seu interlocutor pergunta em quê. "Nas vírgulas" ele diz. "Não escrevo porque gosto, mas porque sou obrigado. Continua achando bonito?" O escritor proseador acha aquilo tudo muito esquisito e diz "sim, que saco, preste atenção". Vai embora.

As vírgulas, e a pontuação em geral, merecem uma reflexão pormenorizada no IRC. Não são apenas regras gramaticais que enriquecem o discurso. Aqui elas adquirem uma função discursiva e simbólica. Vírgula ou não vírgula, características de um nick: sua identidade se encontra entre as vírgulas. Veja a minha, vive andando. E eu correndo atrás dela. ${ }^{4}$

O nick era "Senhor". Ele disse: "Esse pessoal fica mudando de nick todo o tempo, e você é obrigado a ficar decorando hosts... onde esse mundo vai parar? Veja este tal de linux-nit, por exemplo. É o unha, eu conheço. Mesmo porque não há outro inútil no planeta que digite sem espaço entre as virgulas e com esse acento, que na verdade é uma aspa".

Vale um paralelo com a fotografia, com o processo de revelação da foto. A transferência de emulsão é uma delicada operação que separa a gelatina da sua base, do papel fotográfico, o que torna possível ao artista a manipulação da emulsão que contém a imagem. A técnica consiste num grande decalque que permitir a transferência para outro suporte. Da mesma forma, as transferências de traços pessoais entre os 
usuários, pelos canais, é um fato comum, quase corriqueiro, por vezes patético. Usam o comando /nick como quem manipula a gelatina do papel fotográfico. Tempos de Photoshop.

Certa vez encontrei um usuário bastante culto no IRC. Jornalista viajado, trabalhava no ambiente jurídico e fazia campanhas políticas. Estava escrevendo um livro, ou um jogo, ou uma combinação de ambos, coisa de publicitário. Disse que era ficção, "pois ficção é o que coloco na boca dos políticos, um realismo mágico". Depois de praguejar contra a profissão, narrar o "show da máscara" e a dança dos poderes, diz que neste seu romance o personagem joga uma partida de um jogo estranho, mistura de pôquer com xadrez. Nele, avisa, as peças não são o que parecem: joga-se pôquer para vencer e xadrez para manter. Pretendia ser mais uma metáfora da política que um jogo propriamente dito.

Estávamos conversando sobre o medium, o IRC, e lhe disse que o que particularmente me incomodava era a ausência de uma parte específica do corpo: os olhos. Conversar sem ver os olhos do outro, disselhe, é uma tortura. Lembro de ele dizer que isso não lhe parecia um problema, pois a ausência desse referencial imediato do diálogo faz com que observemos melhor as palavras. Como publicitário que trabalha com campanhas políticas, devo alertar - disse-me - "que os olhos também mentem. Aliás, os olhos estão mentindo mais do que as palavras" ${ }^{\circ}$. Talvez ele não soubesse, mas o caso era ainda pior: só se lê o que se quer, mesmo quando ainda é possível ir além disso.

Ou seja, o problema é ainda mais complicado. Mas encontrei também, certa vez, um usuário com uma interessante teoria, que mesmo partilhando do meu temor, entendia de maneira inversa meu estranhamento com a ausência dos olhos. Dizia que enquanto conversava com seus virtuais amigos, lia e gostava das mentiras, não dando valor especial a elas. Apenas conversava, e nesse ínterim descobriu que era possível detectar a honestidade, contundência ou convicção naquilo que diziam. Os olhos, disse-me, "não compreendem apenas o globo ocular, mas toda sinceridade rarefeita que se encontra numa palavra". Respondi com um "hmmm" e fui dormir, pensando. O que vem a seguir é, talvez, uma resposta a isso tudo.

Assim, os chats e suas flicagens comunicacionais. Uma epifania digital. 


\section{NOTAS}

${ }^{1}$ Houaiss, Antônio. Dicionário Houaiss da Língua Portuguesa. São Paulo: Objetiva, 2001.

${ }^{2}$ Deleuze, Gilles. Proust e os Signos. Rio de Janeiro: Globo, 1981. (p.155-156)

${ }^{3}$ Durante esse período as plataformas de interação simultânea - chats e demais comunicadores - foram um tema central nas pesquisas do universo cibercultural, tal como se pode deduzir a partir da bibliografia listada. A 'Internet são os chats', fora uma frase em nada difícil de ouvir de seus usuários, dado que a interação simultânea é um dos aspectos efetivamente inovadores da grande rede. O afã de escrever sobre o meio, entretanto, já passou. Diante de uma miríade de redes de relacionamento e mecanismos para procura de parceiros, a ansiedade pelo tema dos chats como objeto de estudo enigmático no ciberespaço se apagou ou, como poderíamos dizer em consonância à lógica dos gadgets, seu "tempo passou". Na verdade, não seria suficiente dizer que os chats se tornaram antigos - e assim um objeto em si histórico, documentado. No ciberespaço, é preciso lembrar, não há mistério ou qualidade aurática possível. Os dispositivos que se encontram sucateados são velhos, decrépitos, inúteis velharias corroídas. Curiosamente, é agora - e talvez apenas agora - com o arrefecimento do entusiasmo pelo o dispositivo, que o tempo de necessária decantação reflexiva permite uma análise mais calma (alguém poderia aventar eqüidistante? - mas como veremos não é disto que se trata) sobre o meio. Agora que as atenções e olhos se desviaram desse medium, é tempo de investigar a faceta mais intrigante da grande rede: a interação.

${ }^{4}$ Conversa gravada do canal \#Leiteriakorova da rede Brasnet, ao dia 09/12/1999.

${ }^{5}$ Como, aliás, pode-se ler no poema de Leminski: "ler se lê nos dedos / não nos olhos / que olhos são mais dados a segredos" Leminski, Paulo. $O$ ex-estranho. São Paulo: Iluminuras, 2001. (p.48) 
Para mim, uma tela é em si só um espaço de imersão. Mergulhamos dentro da imagem, assim como nos tornamos parte de uma rede. Jean Baudrillard ${ }^{1}$

O cyberespaço. Uma alucinação consensual vivida diariamente por bilhões de operadores, em todas as nações. Uma apresentação gráfica de dados abstraídos dos bancos de todos os computadores do sistema humano. Uma complexidade impensável. Linhas de luz abrangendo o não-espaço da mente; nebulosas e constelações infindáveis de dados. Como marés de luzes da cidade...

Willian Gibson ${ }^{2}$

A rede é transcendental, porém sem sujeito. O objeto não é mais a coisa, mas apenas fluxos, performances. 
Antes de ligar o computador, antes de vidrar meus olhos na luz branca do monitor, sinto o negrume da tela me observando. Convidativo, dilato meus olhos e ligo, esperando que a transação frite minha retina. O silêncio para num beep mudo mas alucinante, que alerta que o portal está se abrindo, basta entrar. Nunca pensei que a sedução começasse já aqui, no negrume que vira luz. A fascinação que me suga para dentro da tela não é opressiva porque me enfeitiça com um espaldar reticente que lembra: "há de haver uma porta aberta, sempre, mesmo que seja um shut down".

Entre a tela que começa a acender e a tarde que começa a morrer, lembro do universo de possibilidades que a teia digital oferece, jogando-me na babilônica rede perdida. O dia flerta comigo uma outra vez, injetando agradáveis lembranças do que foi feito, do que pode ser feito ainda hoje, já agora. Mal sabe que será o último flerte do dia. Virando a cabeça pela última vez, o resto do dia sorve-se rápido como um boot, que não inicializa o dia de novo, mas o fecha e me prende na cabine simulação, meu cockpit de experimentações digitais. O screen já está ligado. Sorrio com ironia para o dia sem saber ao certo quem é que foi ludibriado nestes segundos de bifurcação.

Olhando esse monitor comprido e consciente, fecho-me numa espiral que se basta a si mesma. Olho de esgueiro para a janela e vejo o fim da tarde ou começo da noite que faz o barulho morrer. Calmamente a noite vai chegando e impondo a infinitude do silêncio. Em breve é hora de conectar, de "logar". Da distância entre meu olhar e a janela, despeço-me da vida, contemplando um dia áspero como todos os outros, e a vontade de sentir os bits engrossando em minhas veias cresce rapidamente. Já não dou adeus, as despedidas ao modo digital são muito mais brutais porque não explicam nem justificam. Apenas apagam. Acostumado à brutalidade dos chips e das máquinas apenas desvio o olhar e engulo a vontade imensa de devorar o dia que vai se acabando. Projeto essa fome na tela, que me devolve luz. Sinto que ainda vivo, palpitando entre chips e projeções. Mãos de pianista que batucam uma reticência uníssona de tentativas, muitas delas frustradas, de trazer para meu computador-oráculo toda a vivacidade que o dia lá fora, rindo, não deixa que se apanhe. Esculpidos nessa temporalidade sem ponteiros, já nos entregamos às tortuosas ladeiras de sentido e repetição que simulam nossa vida, nosso desejo de estar vivo.

Fico feliz novamente ao lembrar das "infinitas possibilidades da rede". A vontade de contatar pessoas que não conheço, ouvir sobre lugares que nunca vi ou imaginar existências que me pareciam impossíveis me anima, e faz crescer a ansiedade por estar online, estar disponível para trocas instantâneas. Nesse ínterim de fantasias, imagino sensações que gostaria de experimentar, com pessoas que gostaria que existissem e que, de um momento para outro, parecem possíveis, disponíveis. Com toda minha força começo a produzir rizomas que não se fecham, linhas imaginárias que trocam todos os fluxos estancados no massacrante sol da tarde gosto de carbono. Não resistindo, conecto-me à teia de bits. Vou atrás dos 
lugares, das pessoas, das sensações. Não são noites ou dias, mas inteiras madrugadas em que passo numa viagem intermitente, permanente, buscando algo que sabendo não estar nos outros, também não está mais em mim. Não me deixo afetar pelo pessimismo de uma queda de linha, de uma mensagem não respondida ou um comentário infeliz. Permaneço sonhando e navegando, enviando mensagens freneticamente, ao gosto dos transmissores de telegramas. Em algum momento disso tudo me atravessa a dúvida se estou a me comunicar ou se a comunicação está a me atropelar. Não sou uma pessoa emitindo opiniões ou sentimentos. Sou uma central de recepção, transformação e emissão alterada. Mecanicamente. Automaticamente. Ignoro a capa técnica que me encobre e parto em busca de cores, animações e movimentos que me entreguem uma imagem definitiva, uma palavra letal, ímpar. Algo que explique para onde toda essa energia me leva, a procura de quem ou o que estou indo.

$\mathrm{Na}$ biblioteca alexandrina de músicas e títulos disponíveis, onde tudo se junta sem cerimônia nem sentido, ouço uma música me dizer que somos sincronizadores enviando mensagens através de códigos. A música então freia, a melodia morre, mas o som continua numa repetição marcada de batidas graves. A letra acompanha os ruídos eletrônicos ressoando na minha cabeça. Máquinas me deram alguma liberdade. Sintetizadores me deram algumas asas. Sou atravessado por samplers de doze bits. Nós somos performers do mundo eletrônico ${ }^{4}$. Familiarizado com o ambiente, sinto-me online e nenhuma nostalgia da vida surrada lá de fora parece ameaçadora.

Uma vez online, a hipnose sensorial se faz completa. Faz-me pensar que um computador, como uma microagência de processamento, sempre sonhou - dentro da sua constituição passiva e feliz - em estar integrado aos seus pares, a todos os outros irmãos de bits. Fraternamente, participo dessa integração infinita, conectando tudo o que se possa imaginar, sem muitas questões sobre a razão disso tudo. Conectar, convergir, integrar e aglutinar. É preciso que toda a maquinaria esteja engrenada em dentes e pulsos, transistores e dados. Imergindo na minha tela lusco-fusco, vou de carona com a rede que convida para que nós todos falemos uma língua que ainda não existe, que provavelmente jamais existirá. Da ignorância que as placas e chips guardam sobre o que me cerca, felicito-me com a idéia que todas as cores usáveis nesta linguagem cor de plástico serão inúteis na dança da eletricidade atarefada. Ficarei observando meus gritos e sussurros dissolverem-se na etérea lógica maquinal.

Calejado, sei que a arte da navegação é entremeada por paciência e insistência. Nunca se sabe quando ou aonde o encontro pode se dar. Aliás, não se sabe que encontro será, nem se será um encontro. Talvez um empurrão, uma trombada. Querendo ver mais, não se deixando tombar, transformo minha ansiedade em poder de clique, e descubro-me capaz de ler não um ou dez, mas 30, 70, 200 sites de uma só vez, vertendo minha sede de explicações para uma trilha nada razoável de acúmulo de pistas, curvas de informações perdidas, que quando coladas formam um lindo mosaico de compreensão enigmática. Clico 
mais, leio mais, converso mais, às vezes acreditando tocar o sentido disso tudo, acreditando estar no encalço dos bits que desaparecem em fios, tubos e conexões que ignoram a pulsação de minha constituição animal, mamífera, sexual.

Desadaptado para uma Era de constituição silícica, observo a grande rede a me afogar em correntezas de dados, com as suas teias movediças e patas imaginárias que tudo pode pegar, tudo nos deixa à disposição. Engolido e enterrado, não percebo mais aquele fim de tarde morrer. Olhando rapidamente para a mesma janela, a noite confirma seu poder de escuridão numa flicagem $^{5}$ entre extremos do negro. Olho o relógio, termômetro que auxilia a não nos perdemos em profundidade, alertando para a volta necessária. É plena madrugada, ainda. A vida que outrora se passava lá fora agora corre como música que não conseguimos ouvir. Enquanto isso, num search imediato, procuro e acho todas as músicas que queria ouvir. Recheio meu surf digital com a trilha que me aprouver, e o dia-tarde-noite lá fora envelhece ignorado.

Posso ser abatido por uma tristeza, uma melancolia. Em verdade, é a saudade do dia que morreu sozinho, mudo e perdido. Afastando-me do monitor, tento me livrar de seu feitiço e vejo com olhos críticos a dança fúnebre desses dados que voltam e vão sem nenhum sentido, nenhum significado. Nenhum conhecimento. Bits solitários, descubro-os ainda mais desesperados que eu, descubro-os cronicamente desorientados. Não tem para onde ir nem estão à procura de nada. Penso nos líquidos da minha boca, nos corpos que se tocam e nos prazeres que se extrai na calada da noite. Neste rápido movimento de jogar a cabeça para trás, desvencilho-me do feitiço e lembro dessas coisas. Lembro dos sucessivos dias que apodreceram lá fora enquanto meu sangue se afina com melodias inesperadas que os espaços vazios do ciberespaço talham na minha percepção. Fragmentado, sei que terei todo o meu sono futuro para preencher de sentido essa troca imaterial, incompreensível e profundamente desleal.

A música segue. Diz que precisamos usar dispositivos para dizer como nos sentimos. Cavalgando por ondas magnéticas, nós procuramos novos programas para o seu prazer. Eu quero costurar minha alma no seu cérebro. BPMs controlam suas batidas cardíacas. Nós somos os sincronizadores ${ }^{6}$. Sim, não há mais dúvidas, parece que preciso de um corpo humano versão 2.0.

Curiosamente, não sinto desprezo pelo ciberespaço e continuo lá. Convenço-me que neste momento o mais interessante seria encontrar minha companhia aqui, agora, de onde talvez já pudéssemos sair e viver nossa condição. Não vou fugir à miséria, vou reparti-la, comungá-la. Já que a tecnologia é um imperativo categórico, vamos então decliná-la como fazemos com os verbos. Acabo por continuar minha busca, realimentado por um feedback que, paradoxalmente, vai me transformando cada vez mais em um energúmeno digital. Conscientizo-me que não importa o tamanho da tragédia, as formas digitais hão de se reproduzir como um vírus. A madrugada, que há algum tempo também já morreu, deu lugar a um dia 
que brilha como revanche sobre esse universo que não é paralelo porque não quer ser real. Nesse deserto de edifícios carcomidos, não há nenhuma importância na doída chuva que começará a cair em poucas horas.

Traído pelos bits que se calam, procuro a temporalidade segura dos segundos cadenciados de meu relógio, mas percebo que eles não compreendem aquele tempo em que me perdi por lá. Incomunicável, sou atropelado pela impotência de ser um endereço, um número, frente às supervias da informação que não informam, não comunicam, não levam a nenhum lugar. Revoltado, constato o que já sabia: que não importa qual via, qual link ou qual servidor: quando as cartas são despejadas no tapete repetem-se sempre os mesmos balés de figuras cansativas, maçantes, de existências unilaterais.

Vacilo em dar termo e acabo desistindo do shut down, pois não há despedida viável neste lugar. Cada logoff guarda um pedaço de morte anunciada e adiada, numa perfeita tortura que não acaba, feita para ter moto perpétuo, transformando as conexões em funções que não tem fim, pois resguardam ao começo um outro começo que está à espreita, só esperando ser chamado. Nessa contingência dupla entre eu e alguma coisa além da tela, assola-me a vertigem de toda uma madrugada, de horas a fio impossíveis de serem contadas, explicadas. Dias, semanas e meses a procura daquela palavra, daquelas pessoas que saídas da minha incessante imaginação feliz, transmutam-se para enferrujados bits paralíticos, incrustados em nós cibernéticos que circulam por aí, soltos, sempre se oferecendo para uma nova tentativa.

Sem saber como ou quando, acabo desconectado. Percebo que o tempo aqui de fora é implacável, e me consome com a mesma vivacidade com que lhe ignorei. Entre a desilusão de um e outro, da janela que indica vida lá fora e o monitor que oferece imersão em vidas lá dentro, lembro que toda viagem tem sua própria face, sua constância e sentido inerentes, que pesar e comparar ambas não ajuda a descobrir os mistérios que nos propomos a cercar nessas andanças aleatórias.

Penso nas pessoas que conversei, que teclamos em comunhão. Pessoas que "penso" que vi, que apenas "acredito" ter conhecido. As imagens são frágeis, imperfeitas, sem definição: próprias da minha imaginação trabalhadeira. Cansado, não me decido sobre o que aconteceu, mas lembro que depois de acordar terei um novo dia. Sem saber que horas será, conforto-me com o horizonte de que, no mínimo, poderei recomeçar. 


\section{NOTAS}

${ }^{1}$ Baudrillard, Jean. A Internet ruma para seu fim. Jornal Folha de São Paulo, Ilustrada, 19/02/1998. O texto que segue é, essencialmente, uma reflexão sobre o processo de imersão, tal como indica a epígrafe de Baudrillard. Demos bastante importância para a questão da imersão porque, segundo nos parece, ela é fundante não apenas nas experiências com salas de bate-papo, mas no próprio sentido que a experimentação de uma rede, de uma tela, proporciona: "Aqui se encontram os ciborgs interfaceados no ciberespaço. São os usuários que se movem no ciberespaço enquanto seus corpos ficam plugados no computador para a entrada e saída de fluxos de informação. Quando os corpos estão plugados, eles sempre apresentam algum nível de imersão. Esta é definida pela diferença qualitativa induzida quando o sensorium de um indivíduo é rodeado por uma cena, em vez de - como no filme, TV e vídeo - facear uma tela à distância. A imersão é, portanto, a posição interna de um indivíduo experiencialmente dentro de um lugar, distinta de um outsider que visualmente consome uma paisagem recortada pela sua moldura. Evidentemente, o sistema perceptivo do usuário fica submergido até um certo ponto. Entretanto, quanto mais o sistema técnico for capaz de cativar os sentidos do usuário e bloquear os estímulos que vêm do mundo exterior, mais o sistema é considerado imersivo. A mais esplêndida metáfora do corpo imersivo pode ser encontrada nem Matrix, o filme." Lucia Santaella continua, em sua perseguição por esquematizações explanativas, classificando a imersão em sistemas eletrônicos em cinco pontos, variando conforme a intensidade. Os chats estariam provavelmente inseridos em um híbrido das categorias de "imersão por conexão" e de "imersão através de avatares". A primeira sugere os processos em que o corpo se encontra ligado ao computador e navega em conexões de hipertexto, acionados sobretudo pelos sentidos da visão e tato. A segunda categoria engloba os processos em que há avatares, que são "figuras gráficas, habitantes dos mundos virtuais. Um avatar é como uma máscara digital que se pode vestir para se identificar a uma vida no ciberespaço. O cibernauta pode incorporar um avatar para se mover em ambientes, encontrar outros avatares, comunicar-se com eles. Neste nível, a imersão avança um passo pois produz-se uma duplicação na sua identidade, uma hesitação entre a presença e a ausência, ser e não ser, aqui e lá." Santaella, Lucia. Culturas e artes do pós-humano - Da cultura das mídias à cibercultura. São Paulo: Paulus, 2003. (p.202-203).

${ }^{2}$ Gibson, Willian. Neuromancer. São Paulo: Aleph, 2003. (p.67-68)

3 Tzu, Sun. A cultura da imanência. IN: Barreto, Ricardo (coord.). Catálogo do Festival Internacional de Linguagem Eletrônica (File). São Paulo: Imprensa Oficial do Estado/Paço das Artes, 2002.

${ }^{4}$ Air, Electronic Performers. 10,000 Hz Legend, 2001. "Uma máquina musical de consistência, uma máquina de sons (não para reproduzir os sons), que moleculariza e atomiza, ioniza a matéria sonora, e capta uma energia de Cosmo. Se essa máquina deve ter um agenciamento, será o sintetizador. Reunindo os módulos, os elementos de fonte e de tratamento, os osciladores, geradores e transformadores, acomodando os microintervaios, ele torna audível o próprio processo sonoro, a produção desse processo, e nos coloca em relação com outros elementos ainda, que ultrapassam a matéria sonora.” Deleuze, Gilles. Guattari, Félix. Mil Platôs - Capitalismo e Esquizofrenia. São Paulo: Editora 34, 2000. Vol. 4. (p.160)

${ }^{5}$ Flicagem, aqui utilizado como metáfora para um deslocamento confuso da percepção - quase uma falha - é um problema técnico que surge quando uma câmera de cinema faz um movimento levemente brusco (como o andamento de uma panorâmica de forma acelerada), produzindo na imagem um borro, algo incômodo de ver. Também conhecido como "fenômeno da trepidação", a flicagem é uma espécie de risco ou chicoteada na imagem por conta de uma rapidez excessiva de deslocamento do objeto focado. Tecnicamente, ocorre por conta de uma pulsação da luz nas partes mais claras da imagem, produzindo a sensação de um "pisca-pisca” intermitente. Há casos em que a telecinagem do digital para a película resulta em flicagem em diversos pontos, sobretudo nas panorâmicas. Para minimizar esse efeito, faz-se durante os transfers uma espécie de efeito blur - algo como um borrar uniforme que dá à imagem um efeito opaco. Muitas das novas câmeras digitais fazem a captura dos frames de forma progressiva, e não através de fields interlaçados, o que reduz drasticamente (ou elimina) o problema de flicagem nas tomadas em que há movimentos com as câmeras, como os pans, os travellings, etc., e que é um dos grandes incômodos na utilização do formato digital para filmagem. Seus fabricantes dizem que o resultado final é ter movimentos tão suaves quanto os realizados com câmeras de cinema.

${ }^{6}$ Air, Electronic Performers. 10,000 Hz Legend, 2001. A versão integral e original da música é esta: "We are the syncronizers. Send messages through time code. Midi clock rings in my mind. Machines gave me some freedom. Synthesizers gave me some wings. They drop me through twelve bit samplers. We are electronic performers. We are electronics. We need to use envelope filters. To say how we feel. Riding on magnetic waves. We search new programs for your pleasure. I want to patch my soul on your brain. BPM controls your heartbeats. We are the syncronizers. We are electronic performers." Ou ainda, como prega o Manifesto Cyberpunk: "Construímos nossos mundos dentro do ciberespaço. Entre zeros e uns, entre os bits de informação. Nós construímos nossa própria comunidade. Nós temos mentes eletrônicas, somos rebeldes de mente aberta. Ciberpunks. Nós vivemos no ciberespaço, estamos em todo lugar e não conhecemos fronteiras." No original: "We build our worlds in Cyberspace. Among the zeros and ones, among the bits of information. We build our community. We are the electronic minds, a group of free-minded rebels. Cyberpunks. We live in Cyberspace, we are everywhere, we know no boundaries.” Kirtchev, Christian As. A Cyberpunk Manifesto. The Cyberpunk Project, 14/02/1997. 
No âmbito ao qual nos remetemos, só é possível o conhecimento relâmpago. O texto é um trovão que depois ressoa longamente. O trabalho deve desenvolver ao máximo grau a arte de citar sem aspas. A sua teoria está intimamente relacionada à da montagem

Walter Benjamin ${ }^{1}$

Podemos multiplicar o seu número tantas vezes quantas queiramos: sentiremos sempre perante o movimento intermediário a desilusão de uma criança que tentasse, juntando as palmas das mãos, esmagar o fumo. O movimento escorregará pelo intervalo, pois qualquer tentativa de reconstituir a mudança com estados implica partir do princípio absurdo de que o movimento é feito de imobilidades.

Henri Bergson ${ }^{2}$

Estamos em uma condição teórica extremamente difícil, pois o objeto que o método deveria abordar na situação atual é difícil de firmar, porque ocorreu uma mudança estrutural muito importante. O pensamento metodológico sempre assumiu, no passado, um certo dualismo entre o ponto de observação e o objeto observado. Porém, hoje parece que não há mais um fora. Se não existe mais um fora, isso cria uma certa dificuldade quando nos defrontamos com a matéria, com o objeto que queremos definir. Estamos dentro, e não fora, nos movimentamos lá dentro. Este 'estar imersos' acaba com toda representação de critérios metodológicos em geral, que justamente previam poder-se enganchar do lado de fora em alguma coisa que fosse estável, e portanto fazer nascer a narrativa daquela estabilidade que determina relações históricas, fixa-as e confere-lhes significado. 
O movimento, efetivamente, não pode ser suprimido. Isso quer dizer que, sendo extemporâneo, deve-se procurá-lo sempre. Por fora do circuito de investigação usual da ciência tradicional, pois suas ferramentas caducaram. A neutralidade axiológica não é apenas uma parábola da ingenuidade científica de tudo querer analisar com frieza, eqüidistância, certeza. A discussão em torno de quão ingênua eram as tentativas de se formular um método de total neutralidade, de absoluta imparcialidade para com o objeto, revela mais que apenas um fracasso superado pela história da ciência. A hipótese da neutralidade axiológica é também sintoma da sede científica de que o objeto pudesse ser captado, compreendido em sua inteireza por um observador distanciado. Mas não pode ${ }^{4}$.

Infelizmente, o movimento tem um andamento próximo do imperceptível, é introvertido e inaudível. Faz chacota com nossa percepção, que desacostumada com tanta discrição, apenas capta o movimento quando de uma transação brusca ou de um desenvolvimento obviamente formal ${ }^{5}$. O movimento, inversamente, só faz passar. Por todos os lugares e sem cerimônia nem causalidade. O intervalo de sua contração e expansão é só uma sombra que se chama fluxo. Relações de velocidade e lentidão por excelência. Afeto é uma estranheza para qual a percepção nunca teve armadilha. Não se percepciona, se é atravessado. Apenas olhar os movimentos, sem intenção de retê-los pois, uma vez ser de fuga, aprende-se que o movimento não pode sequer ser inteiramente percebido. Algo gasoso.

Não se pode agarrar o gasoso, mas pode-se viver em meio a ele. Embebedar-se. O movimento imperceptível quer ser percebido. O paradoxo é apenas lógico, não é operacional: não podemos perceber o movimento porque ele é sempre um outro, diferenciado. Para agarrá-lo então, diferenciação. Onde nos deslocamos relativamente, o movimento é absoluto. Não é uma questão de relatividade, mas de velocidade. Essa assincronia insolúvel entre as linhas e os planos nos habilita a perceber o que não está em um, estando em outro, pululando. Novamente as diferenças entre os planos não se devem ao relativismo, mas a intensidades.

A questão ainda é a do método, embora disfarçada. A percepção do objeto cultivada por este pesquisador não segue a separação cartesiana entre sujeito e objeto, segue antes o movimento que lhes serve de cenário, de contexto e de ambiente. A percepção, neste caso, atua no limite. Entre e durante, em meio de e através de. Para apreender o movimento, ficar atento às passagens.

Observar deturpa observação. E, piorando, nada pode trazer a intensidade do fenômeno de volta, depois de acontecido. O objeto só pode se captado em sua completude quando em ação, e não por meio de relatos perfeitos de um fenômeno que, desaparecido, pertence aos anais do tempo. Enquanto ainda acontecimento, o objeto deve ser capturado, roubado, condição única para tê-lo enquanto fenômeno, antes que desapareça na efemeridade que lhe constitui ${ }^{6}$. 
Assim, essa escrita será co-escrita, será co-captura. Perder o pudor da observação e se deixar pelo fenômeno ser tomado. Ser também afetado, carimbado e registrado. Tomar partido. Sendo este objeto um campo de escrituras intermitentes, posso fazer com que a elas se some minha narrativa, impregnando-a. Não se trata de relatar, numa prática de constatação empírica, os meandros e reviravoltas de um chat, mas de acompanhá-lo ${ }^{7}$, de se deixar envolver pelo objeto sabendo que, rapidamente, ele nos escapará pelos dedos.

Falamos em modus operandi porque não há um método. Há uma captura, há uma caça. Por isso formas de operar, maneiras de agir. Essa subjetividade cibernética só poderá ser reconstruída sobre um complexo de percepções que incluem diversas leituras, subjetivas e materiais, reais e imaginárias - circunscrito na polifonia de percepções, sentimentos, visualizações e relações que constroem a sociedade a partir dos condicionantes da tecnologia. Seriam formas de olhar, de expressar, de sentir, inseridos nessa multiplicidade que não tem vocação para a verdade ou para narrativas totalizantes. Por essas razões, o caráter narrativo e aparentemente ficcional impregna um mapa que, seguindo linhas de singularidade alheias a qualquer centralização, preceito ou prescrição teórica, acaba por fazer prevalecer uma relação diferenciada para com o objeto.

Utilizamos nesta pesquisa o conceito de "cartografia" para designar uma prática que, diferentemente do retrato que representa uma totalidade estática, se faz e se refaz na dependência do próprio movimento que se transforma, se movimenta ${ }^{8}$. Queremos com isso apontar para uma análise perfurada, uma escrita que se embriague dos próprios condicionantes deste meio de comunicação particular. Cartografar aqui implica que não fizemos simples e objetivas entrevistas com os participantes, mas uma conversa sem identificação, algo porosa, pois importa mais o livre fluir das impressões que a totalizante certeza de um enquadramento, de uma pergunta-resposta ${ }^{9}$.

Cartografia: Conjunto de estudos e operações científicas, artísticas e técnicas, baseado nos resultados de observações diretas ou de análise de documentação, visando à elaboração e preparação de cartas, projetos e outras formas de expressão, bem como a sua utilização. ${ }^{10}$

Na ponta dos pés, tentar uma paulatina aproximação com o objeto. Não se trata de descrevê-lo, vale frisar novamente. Um constante retomar de aspectos sugeridos ou implícitos que esta forma de escritura propõe: digeri-los. Pulsar com as cadências intrínsecas do objeto, que é seu aspecto vivo, uma quase máquina poética, um gerador autônomo de textos, impulsionado por um movimento intermitente em que frases surgem, se combinam em arranjos estranhos para em seguida desaparecerem em busca de novas combinações. Essa dinâmica errante, fragmentária e experimental da escritura dos chats é que pode 
iluminar o quadro da sociedade tecnológica. Seus pressupostos e suas práticas condizem com os condicionantes e as extensões informacionais.

Observar esta escritura. Até o limite e inversamente, fazendo com que a análise vire escritura e a escritura possa suar na análise. Reflexividade: nosso modus operandi não é apenas catalogar e referenciar, mas sobretudo fundi-las. Cartografar implica, também, em se fazer parte da paisagem.

Assim, uma escrita-montagem para um objeto-clipe, clipping.

O sentido está no além do desenrolar dos diálogos ou da análise de suas tendências. Tentar analisar o diálogo, a comunicação, é ensaiar o monólogo: pois nos momentos precisos e delicados, o sentido escorrega, engana e trai. No entanto, quando operamos por "colagem", por "cut up"11, as sínteses são solidificadas por uma argamassa de aglomerados distintos, dispersivos e paradoxais. Uma argamassa que, antes de ser suspeita por pertencer ao observador já inserido no objeto observado, é arbitrária porque lhe escapa inteiramente. O objeto está sempre a lhe fugir, escapar, a lhe impor sua condição de estranho. Esta escrita não congela nem fotografa, ela corre atrás.

A apreensão deste complexo de contradiálogos não se faz analiticamente. As reconstruções sucintas, na obsessão pelos signos, uniformizam e fazem desaparecer o que tais diálogos fornecem de singular: seus pontos de não-sentido, que se somam a outros diálogos, imaginários ou não, congruentes ou não. Tentamos driblar as codificações inerentes ao analítico, deslocando a usual coordenação em eixos lógicos de sentido para um esquema tático que deseja ser mutante, que deseja penetrar na sedução do objeto: mapa da mina.

Mapa como malha política abstrata, tessitura nervosa de um social imaterial. O mapa não é o território, terreno territorializado. O mapa é o terreno movente, espaço de marcações provisórias, risíveis, não cristalizadas. Abstração de um espaço que não existe, que não vai existir, terreno da fantasia real. Ainda que o mapa cubra um terreno com precisão, permanece uma abstração, pois não pode cobrir um terreno com fidelidade total sem que se torne ele mesmo este terreno. Dentro da complexidade geográfica dos fractais, o mapa se diferencia por poder indicar tênues malhas dimensionais. Todo um universo de estranhas dimensões embutidas e escondidas que escapam do olhar satélite. Os mapas nunca foram exatos, o mapa não pode nem quer ser exato ${ }^{12}$.

Jorge Luis Borges, num conto fantástico e extraordinário, fala sobre "o mapa", o sonho do mapa utópico que, por ser absolutamente exato, do tamanho da própria coisa mapeada, não tem rigorosamente nenhuma utilidade. Borges é um autor que além de ter em seu pensamento todos os predicativos que a 
Internet realizaria, sempre imbuiu sua escrita de uma crítica subliminar às pretensões de certas ilusões humanas, como a futilidade da precisão total, de exatidões perfeitas. É fundamentalmente um autor que antecipa a crítica às narrativas finalistas e às verdades totalizantes, em uma irônica inversão do humanismo teleológico. Recorrentemente encontramos em seus contos um exaustivo uso de informações e descrições - boa parte delas nitidamente excessivas - para demonstrar que, no final das contas, elas são totalmente ilusórias, incompletas, falsas e impotentes ${ }^{13}$.

\begin{abstract}
Mapa: Representação gráfica, geralmente em uma superfície plana e em determinada escala das características naturais e artificiais terrestres ou subterrâneas, ou, ainda, de outro planeta. Os acidentes são representados dentro da mais rigorosa localização possível, relacionados, em geral, a um sistema de referência de coordenadas. ${ }^{14}$
\end{abstract}

A parte interessante dos mapas é que eles estão em atividade o tempo todo. É o registro de uma atividade, ao mesmo tempo em que fornecem coordenadas para novas atividades. Pensamos aqui em mapas sociais, o aspecto aleatório da cartografia como um gesto que descreve o mundo, co-articulando a lógica sistêmica e a dinâmica da singularidade, o coletivo e o individual. Aos indivíduos da Era Tecnológica, soterrados pela hipertelia, pela explosão de imagens gordurosas, a tradução da informação na forma visual - muitas vezes chamada de cartografia - é menos que um método: é uma maneira de operar, estratégia de codificação ${ }^{15}$.

O rizoma deleuzeano possibilita trabalhar extratos que mesmo quando derivados de uma raiz e sentido comum, permanecem com múltiplas entradas. Um sentido que se quer único e dialético dá lugar à multiplicidade de sentidos, à polissemia de filiações. O rizoma permite preencher os vazios que a teoria colocou debaixo do tapete. Simplesmente porque o rizoma cresce entre, no meio das outras coisas. Enxergar um rizoma é, fundamentalmente, desenhar um mapa movediço, outrora riscado.

Um mapa tem múltiplas entradas, contrariamente ao decalque que volta sempre 'ao mesmo'. Um mapa é uma questão de performance, enquanto que o decalque remete sempre a uma presumida 'competência'16. Essas performances não são retratos de uma estrutura profunda, prognosticada, mas estilos políticos do desejo, entradas e saídas do mapa movente da intersubjetividade social: performances comunicativas.

O princípio do rizoma como um mapa, contrariamente a uma linha, é o que lhe possibilita ter múltiplas entradas. A Internet é feita de muitas rotas, conexões e links entre os computadores. Estes links estão por vezes bem estabelecidos, quando surpreendentemente novas rotas para troca de pacotes e conexões são estabelecidas. Isso ocorre o tempo todo, o que faz das "múltiplas entradas" uma característica operacional da web. Começo a navegar por um endereço qualquer e rapidamente traço um mapa de 
interesse entre páginas absolutamente não conectadas por necessidade ou causalidade. Intencionalmente, movo-me como um nômade, ao invés de seguir trajetos definidos. No bate-papo virtual, os circuitos de deslocamento também são rizomáticos. O que ocorre é que as conexões e os desaparecimentos nômades são piores, mais velozes, mais brutais. Contra esses movimentos de fluxo esquizóides, podemos apenas traçar linhas e desenhar mapas, demarcando suas misturas e ressaltando suas distinções. Quem esteve no meio... atropelado. 


\section{NOTAS}

${ }^{1}$ Benjamin, Walter. Teoria do Conhecimento, Teoria do Progresso. (Theoretics of Knowledge; Theory of Progress). The Philosophical Forum. Vol. XV, 1-2, 1983-84, p.1-40. Tradução de Carlos Eduardo Jordão Machado.

${ }^{2}$ Bergson, Henri. A Evolução Criadora. Rio de Janeiro: Delta, 1964, (p.300).

${ }^{3}$ Negri, Antonio. Cinco lições sobre o Império. Rio de Janeiro, DP\&A, 2003. (p.90). Em sua revisão geral dos postulados marxistas, o autor tem dedicado espaço considerável para as questões metodológicas, e assim resumiu o problema na página anterior (p.89): "Quando aparece uma nova configuração do tecido histórico, da mesma forma teremos uma virada na perspectiva epistemológica. Portanto, toda vez que muda o contexto histórico muda também o método. Não existe um método 'para sempre', universal. Ou melhor, existem métodos que valem 'geralmente' em certas situações e em certos tempos." Idem. ${ }^{4}$ Para tanto, conferir o Projeto Temático "Por uma Nova Teoria da Comunicação", coordenado por Ciro Marcondes Filho, que também versa sobre o Princípio da Razão Durante: "A história da civilização ocidental é a própria história da luta pela autoimposição do racionalismo como modo dominante de pensar. Em todo seu transcorrer ocorreu o conflito entre as visões de mundo que apostavam na estabilidade, na consolidação, na cristalização de fenômenos, processos e desenvolvimentos, e a perspectiva do movimento, da mutabilidade, da permanente transformação. Num vasto período histórico o vivo teve de ceder lugar ao morto, o novo ao velho, a criação à repetição. A crise do humanismo representou uma posição menos soberana do observador e um olhar mais igualitário ao seu objeto de pesquisa. Propõe ao desenvolvimento científico desfeito dos mitos de controle, de dominação e de previsibilidade, que neste momento precisa dar conta de outras lógicas e outras visões concorrendo pela investigação do mesmo fenômeno. Trata-se das ambigüidades que passam a fazer parte também da observação científica e que precisam ser consideradas caso se queira melhor conhecer o real. A recusa das escolhas duais, a consideração de que o real é necessariamente múltiplo, complexo, um emaranhado de diferentes tendências, fluxos, movimentos, histórias, etc. e a observação de que os dados também podem nos manipular encerram o quadro de indicações para se pensar uma nova ciência e um novo procedimento de pesquisa". Renato Janine Ribeiro apresenta o problema sobre essa ótica: "As ciências humanas partem do escândalo que é o ser humano conhecer a si próprio, misturando as posições de sujeito e objeto. Isso formula sérios problemas, tornando quase impossível a objetividade, que é o critério básico das ciências desde o século XVII. Segundo Claude Lévi-Strauss, Rousseau fundou as ciências do homem ao perceber que nelas é perturbadora a relação entre o homem como sujeito cognoscente e como alvo deste mesmo conhecimento. Assim, o mesmo recorte que permite fundar as demais ciências é aquele que as humanas põem em xeque, tematizam, contestam." Ribeiro, Renato Janine. Novas fronteiras entre natureza e cultura. IN: Novaes, Adauto (Org.). O Homem-Máquina. A ciência manipula o corpo. São Paulo: Cia das Letras, 2003. (p.17).

5 "O movimento é um misto: de uma parte, o espaço percorrido pelo móvel, que forma uma multiplicidade numérica indefinidamente divisível, da qual todas as partes, reais ou possíveis, são atuais e só diferem em grau; de outra parte, o movimento puro, que é alteração, multiplicidade virtual qualitativa”. Deleuze, Gilles. O Bergsonismo. São Paulo, $34,1999$.

6 "Encontrar é achar, é capturar, é roubar, mas não há método para achar, só uma longa preparação. Roubar é o contrário de plagiar, copiar, imitar ou fazer como. A captura é sempre uma dupla-captura, o roubo, um duplo-roubo, e é isto o que faz não algo de mútuo, mas um bloco assimétrico, uma evolução a-paralela, núpcias, sempre 'fora' e 'entre'”. Deleuze, Gilles e Parnet, Claire. Dialogues. Paris: Flammarion, 1977.

7 "Seria preciso opor dois tipos de ciências, ou de procedimentos científicos: um que consiste em 'reproduzir', o outro que consiste em 'seguir'. Um seria de reprodução, de iteração e reiteração; o outro, itineração, seria o conjunto das ciências itinerantes, ambulantes. Reduz-se com demasiada facilidade a itineração a uma condição da técnica, ou da aplicação e da verificação da ciência. Mas isto não é assim: seguir não é o mesmo que reproduzir, e nunca se segue a fim de reproduzir". Deleuze, Gilles e Guattari, Félix. Mil platôs. Vol. 5. Rio de Janeiro: Ed. 34, 1997. (p.39).

8 "Paisagens psicossociais também são cartografáveis. A cartografia, nesse caso, acompanha e se faz ao mesmo tempo que o desmanchamento de certos mundo - sua perda de sentido - e a formação de outros. Sendo tarefa do cartógrafo dar língua para afetos que pedem passagem, dele se espera basicamente que esteja mergulhado nas intensidades de seu tempo e que, atento às linguagens que encontra, devore as que lhe parecerem elementos possíveis para a composição das cartografias que se fazem necessárias. O cartógrafo é, antes de tudo, um antropófago." Rolnik, Suely. Cartografia Sentimental: Transformações contemporâneas do desejo. São Paulo: Estação liberdade, 1989.

${ }^{9}$ A eficácia das entrevistas usualmente utilizadas por uma metodologia etnográfica encontra sólidos problemas referentes ao papel direcionador do entrevistador. Transferi-la para o ambiente virtual seria amplificar um hiato insolúvel entre a veracidade da fonte, e o controle mínimo de influência sobre o entrevistado, situação esta absolutamente impossível no ciberespaço. No respeitante à artificialidade das entrevistas como método de coleta, a discussão decorrente do universo de cinema documental é rica e útil, sobretudo em vista destes problemas, como apontam Marcelo Masagão e Jean-Claude Bernadet em http://www.estacaovirtual.com/arquivo/mat2002/nemgravata.htm. Fundamentalmente, trata-se da mesma fratura epistemológica que assaltou a ciência no início do século, tal como debatido na terceira nota de rodapé deste trabalho. Baudrillard assim a entende: "A partir do início do século XX, a ciência reconhece que qualquer dispositivo de observação em nível microscópico provoca tal alteração do objeto que seu conhecimento se torna perigoso. Isso é uma revolução, já que põe fim à hipótese convencional de uma realidade e de uma ciência objetiva, porém, o próprio princípio da experiência está intacto. O que atuava ali era apenas a certeza, e foi feita nova convenção, a da incerteza. Os resultados se tornam relativos nos funcionamento da própria ciência como meio - mas essa relativização mostra supremo orgulho". Em seguida arremata com o 
problema discutido nesta nota: "Nas ciências humanas, o equivalente pressentido mas nunca analisado em suas conseqüências extremas é a pressuposição e a indução de toda resposta possível pela própria pergunta e, portanto, a inutilidade da análise e da interpretação.” Baudrillard, Jean. As estratégias fatais. Rio de Janeiro: Rocco, 1996. (p.72)

${ }^{10}$ Verbete primeiro de Cartografia: "Vocábulo criado pelo historiador português Visconde de Santarém, em carta de 8 de dezembro de 1839, escrita em Paris, e dirigida ao historiador brasileiro (Francisco) Adolfo Varnhagen. Antes da divulgação e consagração do termo, o vocábulo usado tradicionalmente era cosmografia." Oliveira, Cêurio. Dicionário Cartográfico. $2^{\circ}$ ed., Rio de Janeiro: IBGE, 1983.

${ }^{11}$ A idéia do recorte em cut up, tal como Willian Burroughs utilizava, parte do princípio que toda narrativa, cinematográfica ou não, é o resultado de uma colagem, de uma montagem. É um método de edição bastante criativo que se assemelha à montagem fotográfica, com recortes, remontagens e justaposições de planos produzidos com diversos materiais: trechos de jornais e revistas, pedaços de poemas, anúncios e propagandas, excertos de música, fotos e etc. Este material é disposto de uma maneira diferente, criando novas reverberações de sentido. Entre os artistas que exploraram o cut up encontram-se também Brion Gysin e Tristan Tzara.

${ }^{12}$ Para Hakim Bey, "O mapa está fechado, mas a zona autônoma está aberta. Metaforicamente, ela se desdobra por dentro das dimensões fractais invisíveis à cartografia do Controle. E aqui podemos apresentar o conceito de psicotopologia (e psicotopografia) como uma "ciência" alternativa àquela das pesquisa e criação de mapas e "imperialismo psíquico" do Estado. Apenas a psicotopografia é capaz de desenhar mapas da realidade em escala 1:1, porque apenas a mente humana tem a complexidade suficiente para modelar o real. Mas um mapa 1:1 não pode "controlar" seu território, porque é completamente idêntico a esse território. Ele pode ser usado apenas para sugerir ou, de certo modo, indicar através de gestos algumas características. Estamos à procura de "espaços" (geográficos, sociais, culturais, imaginários) com potencial de florescer como zonas autônomas - dos momentos em que estejam relativamente abertos, seja por negligência do Estado ou pelo fato de terem passado desapercebidos pelos cartógrafos, ou por qualquer outra razão. A psicotopologia é a arte de submergir em busca de potenciais TAZs". Bey, Hakim. TAZ: Zona Autônoma Temporária. São Paulo: Conrad, 2001. (p.23) Vamos sugerir uma interpretação para a psicotopologia ou psicotopografia de Hakim Bey que é, antes de qualquer coisa, a que compreenderemos neste trabalho. Topografia, na grafia e acepção original, compreende o ato de descrever através da escrita um determinado local, tal como os antigos topógrafos faziam. Posteriormente, a palavra também foi empregada para designar o próprio ato de desenhar um mapa, que é, naturalmente, mais uma descrição visual que textual de certo local. Desses múltiplos aproveitamentos a que a palavra foi submetida ao longo do tempo, o que resta e nos importa, é que não se deve entender estes intentos como a exata escrita de um lugar, mas mais exatamente de uma escrita com e nos lugares. Isso quer dizer que os arrolamentos entre o espaço e o sentido de seus tópicos não são distinguíveis; são na verdade inseparáveis.

${ }^{13}$ É a história de um imperador que encomenda um mapa exato do seu império, nos mínimos detalhes. Os cartógrafos do império se dedicaram à tarefa e reproduzem o terreno com perfeição: um mapa que coincidia ponto a ponto com o império. Constataram, porém, que o mapa não era útil, pois tinha o tamanho do próprio império. O trecho, na tradução de Flávio José Cardoso, ficou assim: “... Naquele Império, a Arte da Cartografia atingiu uma tal Perfeição que o Mapa duma só Província ocupava toda uma Cidade, o Mapa do Império toda uma Província. Com o tempo, esses Mapas Desmedidos não satisfizeram e os Colégios de Cartógrafos levantaram um Mapa do Império que tinha o Tamanho do Império e coincidia ponto por ponto com ele. Menos Apegadas ao Estudo das Cartografias, as Gerações Seguintes entenderam que esse extenso Mapa era inútil e não sem Impiedade o entregaram às Inclemências do Sol e dos Invernos. Nos Desertos do Oeste subsistem despedaçadas Ruínas do Mapa, habitadas por Animais e por Mendigos. Em todo o País não resta outra Relíquia das Disciplinas Geográficas. [Suárez Miranda: Viagens de Verões Prudentes, livro quarto, cap. XIV, 1658.]”. Borges, Jorge Luís. Do rigor da ciência. IN: Borges, Jorge Luís. História Universal da Infâmia. Porto Alegre: Globo, 1978. Para uma tradução revista, ver: Borges, Jorge Luis. Obras Completas. Rio de Janeiro: Globo, 2000. Outra história interessante, a esse respeito, repousa nos diálogos platônicos, sobretudo em Crátilo, onde Platão discute o limite que a semelhança pode conter antes de ser abolida. Trata-se da fronteira em que o objeto assemelha-se integralmente à cópia, onde não é mais possível distinguir o modelo da coisa real. Não por menos, Cratilismo é o termo utilizado para designar a tentativa de fazer, do signo ou da imagem, não apenas uma cópia indiciária do modelo, mas a própria coisa.

${ }^{14}$ Oliveira, Cêurio. Dicionário Cartográfico. $2^{\circ}$ ed., Rio de Janeiro: IBGE, 1983.

${ }^{15}$ A esse respeito, houve um interessante debate entre Vilém Flusser e Florian Rötzer sobre como a escrita da filosofia deveria ser feita. Flusser entende que é preciso uma reinvenção no método e na teoria para abordar os objetos comunicacionais, agora imageticamente: "Rötzer contra argumenta dizendo que filosofar com imagens significa fabricar cenas mas não poder fundamentar nem explicar nada, que foram até hoje normativos para a filosofia. Mas Flusser insiste que esse é um método a ser abandonado: não se trata mais de causa e conseqüência, mas de acaso e necessidade; deve-se permitir ao pensamento saltar de surpresa em surpresa e ver as coisas de um ângulo oposto, como o polvo, diz ele, que vê o mundo a partir da perspectiva do fundo do mar. Não se parte nem de cima (da transcendência) nem de baixo (da estrutura), parte-se da lateral. Há espaços e tempos alternativos com uma técnica que nos permite tanto projetar cenas que podem ser pelo menos comparadas em concretude àquelas percebidas pelos sentidos, quanto filosofar alternativamente. Todas as realidades são virtuais, a realidade é um conceito-limite ao qual podemos nos aproximar mas nunca atingir. Por isso, o par não deve ser real/fictício mas concreto/abstrato, pois este último permite graduar a observação. (...) Para a tecnoimagem, não há nenhum critério para validar um ponto de vista diante dos demais: a boca do copo pode ser redonda, oval ou como uma linha. Se no passado o intelecto adequava-se às coisas do ponto de vista historicista, no universo das tecnoimagens, a posição do conhecedor e daquilo que ele está conhecendo torna-se uma 'dança de pontos de vista'”. Marcondes Filho, Ciro. O Princípio da Razão Durante. Trabalho de circulação restrita, 2005.

${ }^{16}$ Deleuze, Gilles. Guattari, Félix. Mil Platôs - Capitalismo e Esquizofrenia. São Paulo: Editora 34, 2000. Vol.1 


\section{MÁQUINAS DE GUERRA E CONTROLE DO CIBERESPAÇO}

A máquina de guerra nômade conquista sem ser notada e se move antes do mapa ser retificado.

Hakim Bey ${ }^{1}$

As modas varriam a juventude do Sprawl à velocidade da luz; subculturas inteiras podiam surgir de um dia para o outro, florescer por algumas semanas e desaparecer sem deixar rastro.

Willian Gibson ${ }^{2}$

Hakim Bey (pseudônimo de Peter Lamborn Wilson) é um autor marcado pelo situacionismo sessentista, movimento político e artístico que concebia intervenções no espaço público de maneira a romper com o establishment político e cultural. Os ensaios político-filosóficos de Bey produziram as concepções de anarquia ontológica e terrorismo poético e, por fim, de zona autônoma temporária, conceito derivado de seus estudos históricos sobre as utopias piratas. Uma TAZ (Temporary Autonomous Zone) pode ser uma porção de coisas e é vão defini-la com muita precisão.

A própria bíblia do situacionismo, a Sociedade do Espetáculo de Guy Debord, ganhou sua versão brasileira apenas em 1997 pela editora Contraponto, trinta anos depois do lançamento francês. O pano de fundo do situacionismo ${ }^{3}$ questionava o que era a arte, seu papel social, estético, político e a possibilidade de conter em si mesma o germe de uma nova sociedade. Essas questões norteavam os debates da Internacional Situacionista na França de 1960. No Brasil, entrementes, esse movimento demorou a aparecer e só ganhou penetração por meio de outros debates. Apenas recentemente o mercado editorial brasileiro editou obras oriundas do movimento. A própria bíblia do situacionismo, a Sociedade do Espetáculo de Guy Debord, ganhou sua versão brasileira apenas em 1997 pela editora Contraponto, trinta anos depois do lançamento francês.

O mote teórico de Bey (que sintomaticamente não é seu nome real) trata de estabelecer conexões entre a dinâmica psicológica individual e os sistemas sociais. Apesar de os sistemas sociais serem feitos de muitos sistemas psíquicos (ou consciências, como entende de maneira homóloga Luhmann), haveria uma relação de duplo condicionamento nessas categorias. Ou seja, os sistemas de consciências (psíquicos) 
estariam umbilicalmente ligados aos sistemas sociais (sociedade), afetando-se mutuamente. É certo que essa proposição não é nova nem estranha à sociologia, que a toma como conceito basilar. Ocorre aqui, entretanto, que Bey vasculha uma miríade de imbricamentos entre essas duas instâncias, macro e micro.

É nessa dificuldade em se trabalhar simultaneamente com a macro e a micro e manifestação social que o autor pode contribuir com suas provocações. Esse hiato teórico reflete a insolúvel dificuldade da sociologia em conseguir traçar linhas de sentido entre níveis diferentes, entre temáticas e problemas que ainda que teoricamente conectados, mostram-se operacionalmente auto-excludentes. Isso porque o congelamento estruturalista tem como efeito colateral o extermínio dos movimentos, que constitui em si mesmo as conexões entre os objetos, o tráfego de sentido entre as escalas.

Mesmo o conceito de Lebenswelt da fenomenologia husserliana não consegue desenhar os efeitos correspondentes que o consenso da experiência vivida poderia fornecer. Ocorre que esse fundo comum entre indivíduos unidos num contexto dado não coincide com o sistema social que a própria teoria fez possível desenhar. A relação não é passível de correlações ou de elucidação mútua. O campo do vivido, assim, chafurda nos espectros do inefável, do fluido, do incerto, do mutável ${ }^{4}$, apartados por uma inépcia lamentável das manifestações que lhe deram origem: o estável, as estruturas, as instituições, as regulamentações e as leis. O que Hakim Bey pode ajudar-nos a ver é que - excluindo seu conteúdo diretamente político e programático - os modos de passagem entre essas duas instâncias da sociedade são passíveis de identificação. Seus rastros iluminam essa argamassa que entendemos como identidade.

O feixe de ações daí resultante seria o padrão emergente que essa mútua relação de afecção pode tornar visível. Seguindo o veio político do americanismo libertário, o autor ilumina a relação de coerção que o sistema social aplica sobre os sistemas psíquicos, agindo como estruturas de controle cujo movimento não é claramente perceptível. O desenho é, por assim dizer, antes o de um Atrator Estranho que o de um Atrator Simples, como entende os estudos do caos. Esse princípio de coerção social atua de maneira a limitar a complexidade e diversidade de padrões de troca nas interações e interpenetrações nos sistemas psíquicos e sociais.

Bey sugere que se remova o sistema de controle não no âmbito social, dado que este não é imediatamente acessível, é sempre construção de um todo com muitas partes, mas no âmbito meramente individual. Sugere, assim, que nos removamos nós mesmos das estruturas de controle, o que teria como efeito a entrada em um espaço onde a dinâmica de relações entre o psíquico e o social seria modulada livremente. É a concepção de anarquismo ontológico que propiciaria a formação de espaços em que a construção mediada do social se faz com uma liberdade autônoma, uma T.A.Z. 
Essas zonas seriam temporárias porque ainda que as expressões das personalidades se dêem de maneira mais livre, sempre permanecerá uma influência residual das estruturas de controle no canal de comunicação dos sistemas psíquicos e sociais, espécie de pressão permanente para que tal canal de atuação dilatada do sistema psíquico no social se desfaça, se submeta aos mecanismos de moderação e organização. Nos termos de Deleuze e Guattari, é a força dos aparelhos de captura.

Apesar da contingência de ser efêmera ${ }^{5}$, os significados possíveis que uma T.A.Z. pode criar são suficientemente poderosos pra superar essa condição. Quando se percebe o que está se passando, quando se toma consciência do processo e se percebe o efeito da T.A.Z. nos espaços de vivência que circulamos, compreendemos toda sua processualidade de uma maneira intuitiva. Isso porque ela não é engendrada pelas ferramentas dos sistemas sociais, é antes efeito de abertura dissonante que os sistemas psíquicos impõem ao composto social. A conseqüência imediata é uma compreensão das estruturas de controle e a diferença existente na natureza de uma experiência sem a mediação deste princípio organizador.

A Babilônia toma suas abstrações como realidade. É precisamente dentro dessa margem de erro que a TAZ surge. Iniciar a TAZ envolve várias táticas de violência e defesa, mas seu grande triunfo está em sua invisibilidade - o Estado não pode reconhecê-la porque a História não a define. Assim que a TAZ é nomeada (representada, mediada), ela deve desaparecer, ela vai desaparecer, deixando para trás um invólucro vazio, e brotará novamente em outro lugar, novamente invisível, porque é indefinível pelos termos do Espetáculo. Assim sendo, a TAZ é uma tática perfeita para uma época em que o Estado é onipresente e todo-poderoso mas, ao mesmo tempo, repleto de rachaduras e fendas. ${ }^{6}$

Não se trata, então, de Universos de referência em geral, mas de domínios de entidades incorporais que se detectam ao mesmo tempo em que são produzidos, e que se encontram todo o tempo presentes, desde o instante em que os produzimos. Eis aí o paradoxo próprio a esses Universos: eles são dados no instante criador, como hecceidade e escapam ao tempo discursivo; são como os focos de eternidade aninhados entre os instantes. Além disso, implicam a consideração não somente dos elementos em situação (familiar, sexual, conflitiva), mas também a projeção de todas as linhas de virtualidade, que se abrem a partir do acontecimento de seu surgimento.

A perspectiva de Bey era a de que esses agregados pudessem se proliferar infinitamente, até que proporcionassem ao sistema social uma comunicação efetiva com os sistemas psíquicos. O veio utilitarista e a flagrante adesão ideológica são evidentes. Mas essa perspectiva política do anarquismo nova-iorquino é um veio interessantíssimo para acrescer às concepções de Luhmann e sua teoria da comunicação, que apresenta vãos operacionais. Faltava ali, parece, algum elemento que pudesse fornecer mobilidade suplementar aos sistemas psíquicos nos seus acoplamentos e interpenetrações com os sistemas sociais ${ }^{8}$. A comunicação não é um sistema, é uma lógica atávica do sistema. 
Era então comum os relatos, na modalidade Henry Miller, de sujeitos a procura de uma T.A.Z., ou a procura de sua T.A.Z. particular, tal com Deleuze iria denominar os CsO (Corpo Sem Órgãos) ${ }^{9}$. Então se viajava para algum lugar distante, em que se pudesse sentir-se estranho, em uma língua outra, em uma cultura outra. A desterritorialização sempre fora melhor efetuada quando, fisicamente, também ocorria. Pode-se dizer que a T.A.Z. encontrou certa facilidade de acontecer nos espaços eletrônicos do virtual ${ }^{10}$, assim como eram freqüentes nas lutas contra a polícia, nas disjunções dos tabus sexuais e em uma infinidade de "tradições" anti-status quo herdeiras das táticas sessentistas. A procura pelas zonas liberadas parece ser, de todo modo, permanente ${ }^{11}$.

Estes espaços seriam como fenômenos de agregação e dispersão, efêmeros e inusitados. Formariam a T.A.Z. coadunando movimentos imperceptíveis e operando por meio do que se convencionou chamar de nomadismo psíquico ou nomadologia ${ }^{12}$, que seriam ações à deriva, despropositadas. A emergência da T.A.Z. requer, assim, que a razão desse encontro seja absolutamente desnecessária: A TAZ é uma arte de viver em contínua elevação. Selvagem, mas gentil - um sedutor, não um estuprador, mais um contrabandista do que um pirata sanguinário, um dançarino e não um escatológico ${ }^{13}$.

Pois foi mais ou menos assim que a Internet se viu identificada já em seus primórdios. O caderno cultural Mais! do jornal Folha de São Paulo reportava já em 1994 uma matéria da New Scientist sobre a materialização da "aldeia global" de McLuhan ${ }^{14}$. O texto diz: a Internet, rede mundial conectada a 18 mil redes em 137 países, mostra que há pelo menos uma dimensão em que a anarquia é possível: a quarta $^{15}$, e comentando o neologismo que a revista inglesa cunhara para a Rede das Redes, "netrópolis", define-a como uma caótica rede estruturada pela escrita e onde se reuniriam as vanguardas do pensamento recém saídas da arte para a explosão tecnológica. Define assim a linguagem ali utilizada: Até uma nova língua, anárquica e selvagem, parece brotar neste mundo paralelo. Acrônimos, desenhos e abreviações convergem numa forma de comunicação altamente eficiente, com a imediatez da conversa e a precisão do texto ${ }^{16}$.

Do ponto de vista processual, essa tipologia de conversa é mais inclusiva do que exclusiva, apesar da alarida exclusão digital. Não se exigem credenciais nem mesmo identificações precisas nas salas de conversa ou nas listas de discussão, basta entrar, ler e participar. Apesar dos recorrentes tópicos para especialistas, é comum o debate se generalizar a ponto de integrantes de diversas áreas poderem palpitar.

É nesse cenário esquizofrênico que a colisão entre uma idéia individual e uma concordância coletiva toma corpo, como veremos no capítulo O buraco negro da descentralização. O embate entre culturas e estilos de vida, permanente, toma a própria sanidade individual como aposta. 
Talvez por isso as identidades pessoais sejam preservadas, resguardadas, pois alvo de constante e obrigatória mutação no medium. Esses chats do IRC, que se comunicam em tempo real, lembram o funcionamento do rádio-amadorismo, como já fora anotado. Tanto em um quanto em outro, a profusão de canais de discussão para entrar e sair alimenta a condição do usuário de não identificar seu nome real ou sua identidade neste espaço. É esse tipo de dinâmica catalítica e mutante que Hakim Bey identifica, na Internet, os termos da T.A.Z., ou seja, enclaves virtuais e temporários que os usuários criam para comutar modalidades identitárias, tendo como produto direto junções culturais distópicas e a criação de novas maneiras de se comunicar.

Os homens de guerra deleuzeanos brotam acoplados às máquinas nômades, complexo conceitual movente que Bey digeriu para parir sua T.A.Z ${ }^{17}$. Não se trata da violência estéril, mas de adjacências, de máquinas de guerra que se criam em revides de ação subjetiva. Não é a centralidade do poder que encontramos em Foucault: instrumental, centralizado e diretivo, ainda que pulverizado em micro manifestações. São antes adjacências de uma máquina que acopla disjunções, formando mosaicos de resistência ativa e de liberação tecnológica. Não é nem a conceitualização moderna de poder nem os velhos mitos da revolução - inverso aparente do determinismo tecnológico que se disfarça de seu oposto. É uma distinta figura de agenciamento: guerreiros nômades.

É outra a concepção de poder onde importa não as diretivas e coordenações dos pólos decisórios, mas suas rachaduras, o cancro que não para de crescer no seio da sua inoperância. Quais linhas se encontram obstruídas, quais linhas podem ser traçadas nesse cenário de desmanches do edifício do poder. O que uma T.A.Z. quer é tornar atual, ativar algumas velocidades do movimento até então congeladas: quer traçar uma linha de fuga com as máquinas de guerra que se apresentarem.

Funciona pela proposição de novos valores e categorias de subjetivação. Quer romper com os aparelhos de captura, traçar uma linha. Como projeto, a desobediência civil, coletiva e não-linearmente organizada. A presença dos ideais alternativos e de contextos bizarros funciona como afronta direta a valores já estáticos, na tentativa de legitimar e renovar os termos daquilo que conhecemos como pacto civilizatório.

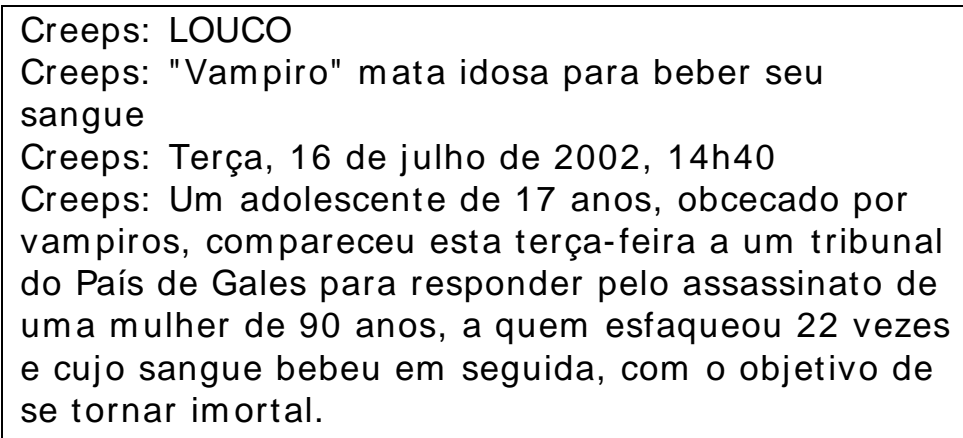

Creeps: DEU O TROCO

Creeps: Americano morde pitbull furioso Creeps: Segunda, 15 de julho de 2002, 16h11

Creeps: Um morador de Nova York, nos Estados Unidos, perdeu a cabeça depois que um pitbull mordeu sua cadela de estimação. Enfurecido, Richard Robbins, 44 anos, mordeu o animal agressor, para espanto da dona, que ainda tentava se desculpar. 
Creeps: Acordei e fui ler o jornal: Advogado dá palmadas em cliente no tribunal. Ele confessou: deu as palmadas porque a mulher não parava de irritá-lo antes do julgamento.

Creeps: O BARQUINHO VAI...

Creeps: Americano atravessa rio em barco feito de rolhas

Creeps: Terça, 16 de julho de 2002, $16 \mathrm{~h} 00$

Creeps: MONSTRO CRUEL

Creeps: Americano é condenado por assar filhote de gato

Creeps: Terça, 16 de julho de 2002, 18h14

Creeps: Um homem da área de Kansas City, nos

Estados Unidos, foi acusado de abuso de animais nesta terça-feira, depois que ele e vários amigos supostamente torturaram um gato de 8 semanas de vida, assando-o vivo em uma grelha. Charles Benoit, de 24 anos, de Liberty, Missouri, pode pegar até cinco anos de prisão e ter de pagar uma multa de US\$ $5 \mathrm{mil}$ se for condenado.
Creeps: olhem mais essa

Creeps: É MAIS BONITO?

Creeps: Romenos preferem as mulheres... de bigode

Creeps: Terça, 16 de julho de 2002, 10 h55

Creeps: Homens de um vilarejo na Romênia preferem as mulheres... de bigode. Em

Baleni-Sirbi, no condado de Dimbovita, o buço é considerado um sinal de fertilidade e fidelidade e essencial na hora de se escolher uma esposa.

Creeps: "Eu gosto quando me olho de bigode e nunca vou raspá-lo. É um sinal de que ocupo um lugar especial", disse Maria Nitoi, 47 anos e um vistoso bigode, ao jornal Libertatea. "Meu marido disse que me ama como Deus me fez. Minha tia tem um bigode, assim como muitas outras mulheres da aldeia".
Creeps: FARSANTE

Creeps: Homem é preso por bancar o eunuco

Creeps: Domingo, 14 de julho de 2002, $19 \mathrm{~h} 14$

Creeps: A polícia indiana prendeu um homem

acusado de se fazer passar por um eunuco. $O$

impostor foi descoberto porque um grupo de eunucos

"verdadeiros" informaram sua suspeita.
Creeps: eu sou um rapaz extremamente

informado

Creeps: sanidade nota 10

[M] ir@deX: Creeps sabe dançar lambada

[M] ir@deX: fez teatro, e também sabe as

tendências da moda.

São jovens, muitas vezes adolescentes e estudantes, morando com os pais. Não se contentam com modelos tradicionais de subjetivação, os pares “família e escola”, “clube e televisão". Estão à procura de modelizações diferenciadas, estranhas. Querem se diferenciar, e então vasculham as bizarrices do mundo. Querem, com isso, convencerem a si mesmos e ao grupo de que ser diferente é possível, talvez mesmo "normal"18.

Esses canais funcionam para que o usuário se diferencie - espaços que se formam assiduamente, se aglutinando para em dado momento se desfazerem, se perderem, cedendo espaço para novos canais, novas formações virtuais subjetivas. Formam-se com uma liberdade frágil e é por isso que devem ser efêmeros. O imperativo de sua constituição também impõe a necessidade de sua dissolução. Imperativo de formar para subverter, de ser temporário.

disquete: Escutem, por que vocês que são portugueses se reúnem neste canal, que é brasileiro? neoteta: tra la ra la la disquete: velho, o que você faz nessa droga de canal? velho_moribundo: a vontade de dizer "uma coisa" é realmente grande velho_moribundo: ops, foi mal.

Brasil: Em meio minuto, a vazão do rio Amazonas mataria a sede de toda população mundial. 
Cornudo: pirlim, você acha a maconha sexual, sensual?

pirlim: não

Cornudo: Apavorante? Paranóica? Eu sinto as duas coisas, mas chamo a paranóia de tara sexual.

pirlim: Você costuma separar tudo que é bom, em sexo, e tudo que é ruim em doentio?

Cornudo: você acha certo que alguém ache "bucetas sujas", e não faça

sexo? É normal?

pirlim: não, isso é um problema sexual. Sexual não, cultural.

Cornudo: O ideal "bucetas sujas" é um sistema de crenças. Veja, nem

todas as bucetas são sujas e tal.

pirlim: $\operatorname{sim} \ldots$ ?

Cornudo: então a cultura vem antes do sexo. É o que quero dizer. E o sexo tem que vir antes da cultura, pois a cultura às vezes até IMPEDE o

sexo, como no caso do cristianismo. Por isto acho-o uma tara doentia.

Cornudo: você sabe o que é um tabu, porquê ele existe?

pirlim: É uma parte de um sistema de crença bem cristalizado

Cornudo: é uma paranóia coletiva, criada por alguém, um sacerdote,

xamã, que impede determinados tipo de sexo que ELE considera errados

por conta de alguma TARA. Taras são contagiosas.

pirlim: você quer generalizar tudo isso, enquanto que essas coisas

interagem com muitas outras, não são tão simples assim

Cornudo: o que você tem contra o sexo ser o centro do homem,

basicamente, me diga.

Mr__ : o q é mais importante, sexo ou dormir?

Gestapo: dormir também é sexo.

pigmeu: meu deus. não, dormir não é sexo, por favor.

Mr__: o canal ficou interessante.

Gestapo: o canal é louco.

Mr_: há um tempo atrás, estava pululando de néscios...

Gestapo: lembramos um hospício

enorme: não, somos idiotas, digo, eu sou, deles eu não sei.

enorme: Gestapo, desculpe mas acho a maior graça nesse canal ...

_Mr__: hoje é sexta-feira (foi, né?), vou cheirar uma carreira...

_Mr_: domingo, aperto um fino na praia do pepino.

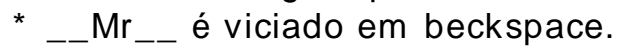

*** UGABUGA changes topic to "Bolo de maconha com chá de cogumelo!

Pra ver a música e ouvir as cores!"

Gestapo: pigmeu, ainda aqui?

pigmeu: claro... serei a

última a sair hoje.

Decidi.

Gestapo: então tá

pigmeu: ficarei até o

último.

Gestapo: vamos ver

quem agüenta mais a

pressão mental, ok?

Vamos ver quem surta antes?

* Fota ... Mindfuck operation in progress... pigmeu: não Gestapo... eu minto. Claro que não quero entrar nessa apostinha. Como já disse, eu me trato. *** Fota changes topic to "Venham conhecer pigmeu!!! Oportunidade única! Não percam!!!_" pigmeu: Fota... por favor, me deixa aqui quietinha. Meus pais me trancam, colocaram um computador aqui... e fico trancada.

Gestapo: você não pode sair ou não consegue sair?

pigmeu: eu não tenho

fantasia nenhuma... sair??????

pigmeu: heheheheh, impossível.

Não seria nenhum absurdo relacionar a formação de algumas dessas hordas disruptivas ao uso da Rede. Isso porque sua estrutura rizomática impõe um desenho de forças, de poder, rigorosamente distinto do que entendíamos na sociedade moderna. Sem cidades fixas ou territórios delimitados, a informação pode apenas precariamente ser controlada, mantendo sua circulação através dos canais. O desenvolvimento de junções nômades no ciberespaço, tal como relatadas acima, indica as prerrogativas desse novo poder instaurado: espiralado, difuso e fractalizado.

A discussão sobre o nomadismo psíquico e as máquinas de guerra vai ao encontro do nó central que as discussões sobre a cibercultura têm se desvencilhado, qual seja: a questão política que a Rede das redes coloca. Isso porque sua própria concepção descentralizada e tecnicamente não passível de controle ${ }^{19}$ 
elege-a como objeto de comprovação empírica dos dilemas atuais do conceito de poder. Esse poder é já um outro e "controle" é um substantivo em muito deslocado ${ }^{20}$.

Do ponto de vista técnico, talvez fosse possível controlar e ter acesso aos dados que a rede transporta, mas isso não é, entretanto, viável. Poder-se-ia fazê-lo através de um controle no nó central da rede, sua espinha dorsal, chamado de backbone e que é por onde a imensa maioria dos dados da rede tem que passar. É a infra-estrutura física central da Internet, por onde as demais redes menores se conectam. Tais estruturas, espinhas dorsais, concentram virtualmente o tráfego da rede e, se houvesse algum lugar para fazer este controle, este seria o backbone $e^{21}$. Entretanto, o afluxo de gigabytes de dados por segundo que passam por tais nós desautoriza essa hipótese, pois essa massa virtualmente infinita de informação não pode ser filtrada nem mesmo conhecida por algum centro capaz de lhe valorar, de lhe compreender. Assim, ainda que tecnicamente possível, é humanamente inviável.

Uma possibilidade freqüentemente aventada é que tais backbones possam ser destruídos, e assim a rede poderia ser posta abaixo. Mas deve-se lembrar que o nascimento militar da rede tinha como propósito inviabilizar justamente essa possibilidade ${ }^{22}$. Ou seja, ao contrário das outras redes, a Internet pode se refazer mesmo que alguns de seus backbones venham a cair. Seu propósito militar era, afinal, ser uma rede que não sucumbisse a um ataque nuclear, que continuasse funcionando mesmo que parte do território, e assim parte de suas instalações, se encontrasse destruído ${ }^{23}$.

Isso acontece pelo fato do protocolo $\mathrm{TCP} / \mathrm{IP}^{24}$ não seguir um único caminho, fixo, preciso e definido anteriormente. A troca de pacotes que este protocolo propõe é indefinível, nunca se sabe por qual caminho seguirá. Os nós da rede vão apenas passando para frente a informação que receberam, indicando para o nó posterior qual é o endereço final a que a informação deve chegar. Ainda que algum nó venha a ser destruído, a troca de pacotes (dados, informação), continua operacional. Para pensar a rede como uma geografia do poder, é necessário antes de tudo ter em vista sua espectralidade, sua descentralização material, operada de maneira radical e efetiva. Ao mesmo passo que nenhuma centralidade totalizante resiste, nenhum golpe fatalista à Rede das redes parece efetivo. Vírus?

Seriam antes maneiras de viver esse poder difuso, maneiras de criar e de destruir por meio de uma estrutura arbórea, descentrada e disjuntiva. A conjuntura é a da mudança de um poder sedentário para um poder fluído, de difícil localização ${ }^{25}$. O terrorismo, que surgiu no novo século como um fantasma ao poder Ocidental, guarda mais discussão que suas finalidades ou sua (ausência de) moralidade podem indicar. Trata-se de entendê-lo como método, não como finalidade. 
${ }^{1}$ Bey, Hakim. TAZ: Zona Autônoma Temporária. São Paulo: Conrad, 2001. (p.19).

${ }^{2}$ Gibson, Willian. Neuromancer. São Paulo: Aleph, 2003. (p.74).

${ }^{3}$ Como veremos no capítulo Táticas de Terrorismo Conversacional, há elementos do ideário situacionista até nos movimentos de contestação recentes, que assumem a tese situacionista da sociedade do espetáculo, em que espectadores-consumidores impotentes encontram na prática do ativismo estético uma maneira de intervir nos locais públicos ou privados.

${ }^{4}$ Não é de agora que o circuito de afecções se faz em espirais fracionadas, não-linerares. Uma reunião ou aglomerado de pessoas não constitui, necessariamente, campo de agenciamento: "Uma vez mais se precisa de um cientista social diferente, capaz de ver dentro da sociedade a existência de manifestações afetivas que não passam mais pelas relações de vizinhança. Pode-se morar em um prédio de apartamentos, de 20 andares, não conhecer absolutamente nenhum de seus vizinhos nos outros andares e, pelo contrário, embora não os conheça, odiar a todos. É perfeitamente possível. Por outro lado, vai-se a um estádio de futebol em que não se conhece ninguém e todos os que estiverem com a mesma camiseta de seu time, ama-se desesperadamente e, se houver um gol, você beija todos na boca! Como é possível? A afetividade tem outro campo, outro canal de manifestação que não é o mesmo da comunidade. É preciso outra concepção para avaliar a mudança da situação." Sevcenko, Nicolau. O Fim da História. Revista Atrator Estranho Nº 19. São Paulo, NTC, 1996.

5 "Penso que a saúde das fratrias depende de que elas tenham vida curta. Em outras palavras: o destino de um fratria, cumprida sua função de criadora de linguagem (ou respaldo para experiências com os limites, o que é a mesma coisa), deve ser sua dissolução espontânea, ou no mínimo seu esgarçamento”. Kehl, Maria Rita. Existe uma Função Fraterna? IN: Kehl, Maria Rita (org). Função Fraterna. Rio de Janeiro: Relume Dumará, 2000. (p. 45).

${ }^{6}$ Bey, Hakim. TAZ: Zona Autônoma Temporária. São Paulo: Conrad, 2001. (p.18).

${ }^{7}$ Guattari, Félix. Caosmose: Um novo paradigma estético. São Paulo: 34, 1992. (p.29, $2^{\circ}$ parágrafo).

8 "Para Niklas Luhmann, a comunicação é alguma coisa muito improvável, muito difícil de acontecer. Pessoas, assim como sistemas sociais, são, em princípio, fechados. Há muita dificuldade em receber informações externas e para que a comunicação tenha algum sucesso, pessoas e sistemas não usam a linguagem, mas acionam 'mecanismos de lubrificação' do processo comunicacional." Marcondes Filho, Ciro. Até que ponto, de fato, nos comunicamos? São Paulo: Paulus, 2004. (p.85). ${ }^{9}$ Talvez os canais de chat possam ser entendidos como uma máquina desejante propriamente personificada, já que elimina de maneira cabal o organismo, a unidade centralizadora que dá organização aos órgãos. Nos termos deleuzeanos, é a desconstrução necessária a um corpo sem órgãos, categoria central que possibilita ao Desejo traçar suas linhas. O incrível é a virtual possibilidade dessa solicitação desejante ser diagramada na logosfera dos bits, do silício, premissa que, em verdade, não é assim tão bizarra: "O agenciamento vital, o agenciamento-vida, é teoricamente ou logicamente possível com toda espécie de moléculas, por exemplo o silício. Mas acontece que esse agenciamento não é maquinicamente possível com o silício: a máquina abstrata não o deixa passar, porque ele não distribui as zonas de vizinhança que constróem o plano de consistência. As razões maquínicas são totalmente diferentes das razões ou possibilidades lógicas.” Deleuze, Gilles. Guattari, Félix. Mil Platôs - Capitalismo e Esquizofrenia. São Paulo: Editora 34, 2000. Vol.4. (p.81).

10 "Como fã do cyberpunk, não consigo deixar de antever o importante papel que o 'hacking da realidade' terá da criação das TAZs. Assim, como Gibson e Sterling, acredito que a net oficial jamais conseguirá conter a web ou a contra-net - a pirataria de dados, as transmissões não-autorizadas e o fluxo livre de informações não podem ser detidos. (Na verdade, no meu entender, a Teoria do Caos pressupõe que nenhum sistema de controle universal seja possível.)”. Bey, Hakim. TAZ: Zona Autônoma Temporária. São Paulo: Conrad, 2001. (p.34).

11 "Que semelhanças podem existir entre o Brasil agoniado dos anos 70, da liberação sexual, dos guerrilheiros e dos poetas marginais, armados com seus mimeógrafos, e o Brasil agitado do século 21, do pragmatismo, da violência e da Internet, com jovens equipados com microcomputadores? Três décadas e o salto tecnológico não foram suficientes para apagar algumas semelhanças e repetições. Tampouco para evidenciar questões, ou impasses, que nunca se chegaram a resolver. A literatura dos transgressores da chamada 'Geração 90' são provas eloqüentes disso'. Castello, José. Sem respostas nem soluções. Revista eletrônica No Mínimo. 10/06/2003.

12 "Fazer do pensamento uma potência nômade não é, obrigatoriamente, mover-se, e sim abalar o modelo do aparelho de Estado, o ídolo ou a imagem que pesa sobre o pensamento, monstro agachado sobre ela. Dar ao pensamento uma velocidade absoluta, uma máquina de guerra, uma geografia, e todos esses devires ou caminhos que percorrem a estepe.” Deleuze, Gilles. Diálogos. São Paulo: Escuta, 1998. (p.42). E também aqui: “Toynbee tem profundamente razão quando sugere que o nômade é antes aquele que não se move. Enquanto o migrante abandona um meio tornado amorfo ou ingrato, o nômade é aquele que não parte, não quer partir, que se agarra a esse espaço liso onde a floresta recua, onde a estepe ou o deserto crescem, e inventa o nomadismo como resposta a esse desafio". Deleuze, Gilles. Guattari, Félix. Mil Platôs - Capitalismo e Esquizofrenia. São Paulo: Editora 34, 2000. Vol.5. (p.52).

${ }^{13}$ Bey, Hakim. TAZ: Zona Autônoma Temporária. São Paulo: Conrad, 2001. (p.74).

${ }^{14}$ Rumo a Netrópolis. Jornal Folha de São Paulo, Caderno Mais!, (p.4-6), São Paulo, 17/07/1994.

${ }^{15}$ Idem.

${ }^{16}$ Ibidem.

${ }^{17}$ As relações entre a T.A.Z. de Bey e a máquina de guerra nômade em Deleuze são claras, e Bey explicita-as no seu curto ensaio. Para uma análise dessas correlações: Morais, Rodrigo de Oliveira. Zona Autônoma Temporária: Web e Máquinas de Guerra. INTERCOM - IV Encontro dos Núcleos de Pesquisa, NP 08, do $27^{\circ}$ Encontro Anual da Associação Nacional dos Programas de Pós-Graduação em Comunicação, Porto Alegre, 2004. 
18 “O vazio das letras é impressionante. Em compensação, as onomatopéias são significativas. Reiterações, falta de sentido, repetições à maneira de ladainhas não precisam ser explicadas, pois remetem a um sentido distante. Limitam-se a participar de uma experiência que permite 'sair de si'. Reencontramos aqui a própria essência do êxtase: o indivíduo que sai de si mesmo para participar do "completamente diferente"”. Maffesoli, Michel. A parte do Diabo - resumo da subversão pós-moderna. Rio de Janeiro: Record, 2004, (p.164).

${ }^{19}$ A mais nova discussão sobre o possível controle da Rede é sobre a distribuição dos IPs, que são as unidades básicas eletrônicas. Nessa perspectiva, tal controle poderia ser feito por meio da alardeada e inevitável mudança para o IPv6, em vista da disponibilidade do IPv4 estar se esgotando e a rede continuar crescendo. Numa perspectiva um tanto quanto paranóica, é imaginável o controle da distribuição dos IPs, concedendo-os apenas para instâncias 'confiáveis'. Mas isso tampouco implica que um controle efetivo da Internet possa ser implementado, pois a própria complexidade estrutural dessa rede demandaria um tipo de automatização e processamento de informação que seria, também e por definição, imperfeito.

${ }^{20}$ Henrique Antoun trabalhou esse tema por meio dos ativismos políticos que fazem uso das ferramentas da cibercultura. $\mathrm{O}$ autor faz uso de uma dicotomia entre o poder da informação, centralista e monopolizador, e as práticas sociais, difusas e cooperativas. No entanto, permanece ainda a suposição de uma disputa pelo 'poder' de um espaço, pela sua ocupação e uso diretivo, ainda que operacionalizado por parcerias. O que estamos tentando colocar é justamente a perversão dos mecanismos em que o poder se faz e se constitui: trata-se da própria subversão do conceito de espaço que, sem ter limite, admite a presença irrestrita de agentes mas não possibilita a capitalização destes numa frente organizada e representativa - categorias centrais desta concepção de poder que entendemos corrompida. Ver: Antoun, Henrique. O poder da comunicação e o jogo das parcerias na cibercultura. COMPÓS - $13^{\circ}$ Encontro Anual da Associação Nacional dos Programas de Pós-Graduação em Comunicação, 2004, São Bernardo do Campo.

${ }^{21}$ E o backbone não é exatamente um patrimônio público. Depois dos pesados subsídios do governo estadunidense para a internet, nos primeiros anos da expansão eletrônica, a rede foi aberta na década de 1990 para empreendimentos comerciais. Como parte desse projeto de privatização da internet, os backbones da porção norte-americana foram gradualmente transferidos para grandes corporações, como a IBM e a MCI. O marco desse processo se deu em 30 de abril de 1995, quando a Fundação Nacional da Ciência encerrou sua participação na Internet e as grandes corporações passaram a assumir o controle. O espetáculo de especulação sobre o ciberespaço, entretanto, rendeu apenas o estouro da bolha pontocom de triste memória, em que uma infinidade de empresas foi à bancarrota e muitos milhões de dólares desapareceram. Não são poucos os que acreditam, por isso mesmo, que o fracasso ocasional do sistema de financiamento da economia eletrônica se deva à incapacidade da rede de reter e privar informação em seus nós. Sua estrutura arbórea inviabilizaria o controle e, em última instância, desacreditaria qualquer possibilidade de convergência com a TV - modelo de excelência nos negócios.

${ }^{22}$ Quando o Departamento de Defesa Americano desenvolveu a Internet, nos idos da década de 1960, seu propósito inicial era criar uma rede de comunicação militar acessível por todo o globo. Cada ponto da rede (ou nó) estaria conectado virtualmente a todos os outros, de maneira que a rede de comunicação (network) continuasse funcionando mesmo após uma grave destruição de suas instalações. Isso seria possível pela maneira particular de rotear a informação na rede, que é permanentemente nãofixa, ou seja, os pacotes de informação podem seguir sempre por um outro caminho, independente das estruturas físicas utilizadas anteriormente. A contingência estrutural de fazer com que a informação circule por qualquer meio disponível transformou-a em um sistema extremamente eficiente, tornando-se rapidamente uma rede de escala mundial conhecida como ARPANet. Na década de 1990, o mundo viria a conhecê-la em toda sua amplitude por meio de sua interface gráfica, o WWW (World Wide Web) ou simplesmente Web.

${ }^{23}$ Apesar de toda essa blindagem estrutural, em abril de 2004 foi anunciada uma falha grave de segurança que supostamente poderia por toda a internet em paralisia. Roger Cumming, diretor do Centro Nacional para Coordenação da Segurança de Infra-Estruturas do governo britânico, chegou a comentar que a exploração da vulnerabilidade poderia prejudicar a própria coesão da Internet. Trata-se de uma falha no TCP descoberta por Paul Watson, que consiste em interromper as comunicações entre roteadores e computadores pessoais, o que permitiria a um usuário mal-intencionado reinicializar remotamente as sessões de acesso à rede. Apesar do alarme, pouca coisa foi comentada a respeito naquela ocasião ou posteriormente. Ver: Internet está sob ameaça de paralisação total, disponível em: http://www.mundoinfo.com.br/

${ }^{24}$ TCP/IP ou Protocolo de Controle de Transmissão / Protocolo da Internet (Transmission Control Protocol / Internet Protocol) é um protocolo de comunicação que organiza a troca de dados em redes, especialmente na internet. Se o IP responde pelo sistema de endereçamento das máquinas, o TCP responde pelo transporte das informações de um ponto a outro, de um endereço IP a outro. Mesmo não sendo o mais seguro nem o mais eficiente, é seguramente o protocolo aberto mais difundido e utilizado em todo o mundo, sendo o principal protocolo de comunicação utilizado na internet, ainda que existam muitos outros. Protocolo de rede é um conjunto-padrão de regras relacionadas ao software e ao hardware do sistema, determinando de que maneira os computadores devem se comunicar entre si dentro da rede.

${ }_{25}$ "Uma característica essencial que coloca o capitalismo tardio à parte das demais forças políticas e econômicas, é seu modo de representação do poder: aquela sólida massa sedentária de outrora se tornou um fluxo eletrônico nômade. Antes da administração informatizada da informação, o centro do comando institucional era fácil de localizar" E logo depois: "É raro o capital tomar uma forma concreta; como o poder, ele existe apenas como abstração. Uma forma abstrata será mais facilmente encontrada em um espaço abstrato, ou sendo mais específico, no ciberespaço". No original: "One essential characteristic that sets late capitalism apart from other political and economic forces is its mode of representing power: What was once a sedentary concrete mass has now become a nomadic electronic flow. Before computerized information management, the heart of institutional command and control was easy to locate." E logo depois: "Capital rarely takes a hard form; like power, it exists as an abstraction. An abstract form will probably be found in an abstract place, or to be more specific, in cyberspace." Critical Art Ensemble. Electronic Civil Disobedience and Other Unpopular Ideas. New York: Autonomedia, 1996. (p. 7, 12). 
Cavaleiros, vocês não podem brigar aqui.

Esta é a Sala de Guerra! Stanley Kubrick ${ }^{1}$

Há sempre um momento em que o terrorista deixa de manipular a gestalt da mídia. Um ponto a partir do qual o próprio terrorista se torna sintomático da gestalt da mídia em si. O terrorismo, tal como o conhecemos, é ligado de forma inata à mídia. Willian Gibson ${ }^{2}$

Defendo a experimentação radical, não do combate à mídia ou da tentativa de reduzir a sua influência ou de encontrar o seu bom uso, mas capaz de conduzi-la ao extremo, ao limite, permitindo-nos então vislumbrar um além, uma ultrapassagem desse ponto crítico. Isso tudo, é claro, se ainda for possível. Jean Baudrillard ${ }^{3}$

A subjetividade permanece hoje massivamente controlada por dispositivos de poder e de saber que colocam as inovações técnicas e científicas a serviço das mais retrógradas figuras da sociabilidade. E, no entanto, é possível conhecer outras modalidades de produção subjetiva - estas processuais e singularizantes. 
Todos os eventos que seguem transcritos foram e não são mais verídicos. Seus nomes e locais em que se realizaram foram alterados para preservação dos participantes. Só existiram nos anais dos bits virtuais, sendo por excelência inexistente. Qualquer semelhança ou analogia com histórias, fatos e pessoas conhecidas é mera coincidência e não guarda nenhum sentido ulterior.

O estilo cut up que será utilizado a seguir, de corte para, fade in ou fade out, serve para narrar cinematograficamente um movimento quase impossível de se registrar, que é o do deslocamento do diálogo. Quase impossível porque as falas, não sendo exatamente um diálogo, são pautadas por um corte bruto e recorrente entre os temas inseridos e rapidamente desenvolvidos: algo parecido a um experimento de velocidade. Falas, comentários, risadas; seguido de uma nova fala, um novo comentário, novas risada. Os temas vão entrando e saindo como numa roda de alimentação contínua.

As salas simulam uma aproximação impossível, nesse papo que vai, naquele papo vem. Amigos ou não, os nicks entabulam uma conversa fluída mas compassada de timing cinematográfico: três falas rápidas, comentário picante, uma piada irônica: risos. Corte. Outro assunto, comentários super-informados, uma piada: risos. Desenvolve-se o assunto rapidamente, uma curiosidade, outra piada: risos. Uma câmera na cabeça e uma montagem invisível. Quem está operando o cut up? Todos. São instantâneos de comunicação que não dão margem à lentidão, paciência ou reflexão. Seu sentido está no corte.

Falamos em táticas de terrorismo conversacional porque se trata de um modo de operar disrupção, fratura. Processo de desconstruir existências, desatar nós afetivos. A prática é um jorrar de palavras que não lembra muito um diálogo, mas antes um fuzilamento. Vale lembrar de Aldous Huxley, que dizia que a palavra é a única arma que se torna mais afiada com o uso.

O modus operandi é de múltiplos ataques simultâneos, com um caótico planejamento que se faz no agora, no improviso, sem comandante, chefe ou general. Terrorismo porque o objetivo é destruir, desconstruir e desmontar. A tática a que estes grupos se servem é a da descentralização, da reversão, e da operação sem uma unidade que concentre informações e ordens. Os paralelos com os grupos terroristas são claros, obviamente não em seus propósitos, mas em suas táticas.

Não é sem sentido que a estratégia dos grupos terroristas vem sendo chamada de molecular, com células que operam livremente e sem a coordenação de uma unidade central ${ }^{5}$. Não é que são apenas livres para operar, são antes incontroláveis, mesmo para seus organizadores. Uma vez acionadas, não se pode interrompê-las - são células que se autoconsomem até o termo da missão. Os Estados Nacionais estão corretamente preocupados com o modo de combatê-las, pois sua alta eficiência se vincula à 
impossibilidade de controlá-las. Não basta prender os chefes pois não há controle. Medida preventiva? Espionagem, quebra da privacidade, abuso às liberdades individuais: Big Brother.

Elas funcionam porque essa é a maneira pela qual a sociedade tem se (des)organizado na Era Tecnológica, e tanto o modo de se construir como o de destruir a tessitura do social seguem paradoxalmente o mesmo princípio ${ }^{6}$. Uma vez mais, a questão da técnica, em toda sua amplitude política $^{7}$. A Casa Branca ${ }^{8}$, muito habilmente, chama o modus operandi das células terroristas de múltiplo, difícil de localizar e combater, pois tais células, como lembra o periódico Vanguardia, fazem uso de uma organização militar parecida com a dos militares, mas são formadas por uma irmandade cujos membros estão dispostos a se sacrificar um pelo outro, como uma mãe faria por seu filho ${ }^{9}$.

Assim na guerra como na arte. Táticas, estratégias: a(r)rtivismo. Multiplicam-se ao redor do mundo, e no Brasil $^{10}$, grupos que compreendem e tratam a arte com conceitos de guerrilha. Não mais se denominam grupos, mas coletivos. Rompem com qualquer idéia de autoria; negam o valor dos espaços institucionalizados da arte; lutam contra o esvaziamento na produção artística e atuam contra a reificação da obra mesma: fazem guerra.

O perfil é, no mais das vezes, antiinstitucional e herdeiro da guerrilha política dos anos sessenta e setenta. A atuação se dá por meio de interferências diretas no espaço público, perturbações, mormente em intervenções abertas que deslocam o foco para áreas esquecidas das cidades. São embates que procuram, revivendo o situacionismo sessentista, revitalizar espaços que a administração e o governo suprimiram, lugares desconectados das estradas e circuitos urbanos centrais. Táticas, em resumo, que na década de sessenta ficaram conhecidas como psicogeografia ${ }^{11}$.

Apesar do revival situacionista, o contexto é já outro. Vale destacar que a luta não é contra a ditadura nem outra questão real que afete o todo da população. A máquina aqui funciona diferente, operando por meio de um agenciamento intersubjetivo que não tem uma finalidade clara (abaixo à ditadura) mas uma contingência confusa (crise do sujeito na Era Tecnológica). A ausência de ideais coletivos e concretos dá lugar a uma fragilidade espectral entre as idéias, causas, compromissos. É a própria configuração de uma realidade tecida por redes, com relações sendo perpetuamente refeitas em novas e constantes conexões, que cria a inviabilidade do compromisso incondicional, do ideal único e coletivo, do objetivo permanente.

Queremos chamar atenção, tanto nas células terroristas quanto nos novos grupos de ativismo político e artístico, não para o conteúdo implícito de seus atos, mas para a maneira, as táticas e estratégias que estas células fazem uso em suas atuações. Independente da finalidade - destruir ou inovar a sociedade - ambos 
trabalham com o horizonte do fim dos metarelatos, dos panópticos e das grandes utopias. O cenário é, dentro da filosofia de Foucault, dos micropoderes. Isso quer dizer que a fragmentação não se dá apenas no universo subjetivo (micro-político), mas atravessa toda a organização do tecido social e suas formas legítimas ou não - de atuação e intervenção política: macro-política ${ }^{12}$.

Estes coletivos procuram apenas um microespaço de sociabilidade dentro das conexões que vão se estabelecendo, continuamente, entre seus pares ou suas subjetividades convergentes. O objetivo é a criação de um local virtual de agenciamento coletivo: criação de uma máquina. Elas funcionam como entrepostos de duração curta, livre e indefinida: zonas de autonomia temporária ${ }^{13}$.

Assim na guerra e na arte, como também nos chats.

* Schwarzeneggger arranca a roupa de Image e joga em cima de Thinner.

* Padre__violento joga mais um pouco de óleo

* Thinner EMPALA Image com a Excalibur, a espada do poder.

Image: o que é que vocês estão fazendo, hein?

Image: hehehehehe

Image: ...tá certo que sou o foda, mas também...

* Thinner mira em Image e PANT! PANT! PANT!

Image: ...três pessoas querendo me matar...

* Padre___violento joga a tocha em Image, que explode em chamas.

* Schwarzeneggger filma Image sendo empalado por Thinner e disponibiliza no Kazaa.

Pianola: INFORME: De acordo com a televisão chinesa, o lançamento do primeiro vôo com tripulantes do país está marcado para o dia 15 de outubro. "Nos disseram que a retransmissão ao vivo do lançamento será dia 15, mas não sabemos a hora exata", explicou um funcionário da CCTV.

* Schwarzeneggger passa o filme para milhões de usuários perversos.

Klavier: O funcionário confirm ou ainda que o primeiro vôo chinês será realizado pelo centro espacial de Jiuquan, mas de um perímetro de lançamento situado na Mongólia interior, a mais de $200 \mathrm{~km}$ da cidade de Jiuquan.

Pianola: teus parentes vão assistir ao vivo da Mongólia, Schwarzeneggger

superbaladeu: alo?

Image: vocês são todos doentes.

Corte para:

Godines: Atenção, pessoal. Tenho uma informação que é do interesse de todos aqui: A Rede

Brasnet está vendendo uma incrivel * * COLEÇÃO DE BICHOS DE PELÚCIA DA PARMALAT* *

German_Schach: Godines agora xupa a cabessa do meu pal

Godines: O que é seu "pal", German?

Godines: Seu computador de mão?

Godines: APRENDE A ESCREVER, PORRA!

RollingStoned: hahahahahaha

* Godines é agora German_O_Analfabeto

* AR-15unicamp entrou no canal

Surdo_Mudo_Sorridente: Olha que legal esse nick, acompanha curriculum vitae.

Estivador_de_mulheres: Olha, German_Schach. Fizemos uma reunião e chegamos a conclusão de que você NÂO TEM A MENOR GRAÇA.

German_Schach : minhoca e tua mãe se engasgou filho da puta Escol Paraplégico: Graça??

Estivador_de_mulheres: Assim sendo, decidimos por unanimidade mandar você para o inferno. De acordo?

@Planalto: Acalmem-se crianças..

PlatiBUS: Olha que estou lendo seus palavrões, heim meninão!

* PlatiBUS imagina um garotinho numa cadeira grandona falando devagar "acalmem-se crianças". 
@Planalto: É assim mesmo!

@Planalto: Às vezes até troco os botões. :)

* PlatiBUS passa a mão na cabeça de Lancelot_DuLac como quem agrada a um mico-leão.

@Planalto: Vamos parar de radicalismo!

Modista_extremado: Os muçulmanos são pessoas que moram longe.

Modista_extremado: Já os cristãos, infelizmente, moram perto.

Falamos em terrorismos em sentido metafórico, insinuando não se tratar de revolução, projeto civilizatório ou reformismo político. Trata-se de desestabilização. São ajuntamentos que não se preocupam com a permanência, são temporários e, por isto, levantes. Ainda que, como levantes, não possam ocorrer todos os dias, fazem valer a moeda da intensidade, da diferença que produz mais diferença.

Terça, 15 de julho de 1997, 20h03, Canal \# Hackerz

$<\mathrm{Al}>$ Eu sei fazer um ponto solto no espaço:

$<\mathrm{Al}>$.

$<\mathrm{Al}>$.

$<\mathrm{Al}>$.

$<\mathrm{Al}>$.

$<\mathrm{Al}>$.

$<\mathrm{Al}>$.

$<\mathrm{Al}>$.

$<\mathrm{Al}>$.

$<\mathrm{Al}>$.

$<\mathrm{Al}>$.

$<\mathrm{Al}>$.

$<\mathrm{Al}>$

$<\mathrm{Al}>$.

$<\mathrm{Al}>$.

$<\mathrm{Al}>$.

$<\mathrm{Al}>$.

$<\mathrm{Al}>$.

$<\mathrm{Al}>$.

$<\|-\|>$ É um belote esse seu ponto.
Bey chamava suas T.A.Z. de "anarquia ontológica" ou de "terrorismo poético". Esta segunda explicação nos é bastante interessante, pois incorpora o sentido temporário e nômade de uma máquina de guerra: mobilidade. São táticas de terrorismo conversacional na medida em que difundem o nó da diferenciação, forças que desaparecem e reaparecem movendo-se dentro de padrões rizomáticos. Operam levantes de bobagem desmedida, mas que criam uma dissensão, uma desarmonia entre os presentes. É guerrilha de imaginação, aparecendo e se desintegrando para formar-se, posteriormente, noutro local, ainda que seja apenas mais informação na $\mathrm{Web}^{14}$.

Quinta, 17 de Julho de 1997, 00h50. Interna, Canal \# Cinema

: hahahahahahahahahah (risada sórdida)

Preciso_de_ajuda: hehehehe...(risada fingida)

Preciso_de_ajuda: vida de traço é difícil.

: Não sou traço, sou Uma linha.

: é diferente.

Preciso_de_ajuda: peraí

Preciso_de_ajuda: você nunca me disse isso, que absurdo!

* ___ é agora Ajuda

Ajuda: Imperador..

Preciso_de_ajuda: sim?

Preciso_de_ajuda: pô, que ajudinha mixuruca

ajuda: melhor...

ajuda: agora quero falar de uma coisinha que pensei. 
Preciso_de_ajuda: ah eh?? qual?

ajuda: você viu isso que brincamos?

ajuda: do Imperador...

Preciso_de_ajuda: sim, o imperador.

ajuda: foi improviso, ok... Imagine então que isso pudesse ser feito com um mínimo de plano.

ajuda: um mínimo de ordem, com mais pessoas.

Preciso_de_ajuda: hummm. seria teatro...

ajuda: Pode ser. E mais personagens, seria roteiro.

ajuda: pronto!

End of \# cinema buffer Thu Jul 17 00:55:20 1997

Corte para:

Sexta, 02 de maio de 1997, 06h06, Canal \# Cinema

Lentes: 5 cilindros turbo, 2 kkk, pura engenharia alemã, meu deus! Aquilo era um sonho, não um

carro, pura estupidez em forma de automóvel.

Lentes: tem um OVNI com motor de brasília voando aqui perto.

Lentes: E tem carburação dupla.

Lentes: silencio...

Lentes: os jornais ainda não chegaram.

CALELONTE: não escutei a bordoada do jornaleiro aqui ainda

CALELONTE: apocatástase social, políticas de sedução, nominações insignificantes, perda de tempo.

Lentes: você

CALELONTE: nós

Lentes: ele

Lentes: lapso de tempo, linhas digitais, chão, tonel, não mudo de opinião.

Lentes: a quem interessar possa: isso era poesia...

Lentes: operator, can I help you?

CALELONTE: associações. associações ridículas.

Internet: uma rede de informação formada por incontáveis computares reunidos por um protocolo de operação. Mas a questão fundamental no que concerne a Internet não é nem a informação que ela faz circular nem a estrutura física do meio, mas sua original forma de distribuição. Essa é uma questão de todo política. A internet não é um medium que reúne todos os outros em um, é antes uma maneira de distribuir qualquer coisa. É um sentido. Descentralização e deslocamento dos dados, toda uma máquina abstrata. Há na Internet, decerto, indícios de esgotamento do modelo dos outros media, o esfacelamento das redes de distribuição centralizadas, superpoderosas, que se tornaram grande demais, saturada demais. A Internet não é simplesmente uma "nova economia", em consonância com a anterior, real e histórica. É o estranho momento em que a informação adquire um novo modelo de distribuição, uma estrutura.

Pois para mim a Internet não é nada, se não entendermos que as pessoas estão aprisionadas, sem conforto, numa estrutura que as tolhe, numa ordem que as oprime. A Internet não é nada, se não enxergarmos que as sociedades estão em colapso, à beira do abismo. A Internet não é nada, se não sacarmos que não há mais razões para os agrupamentos, não há mais vontade de massificar-se. A Internet é uma idéia malograda, se não admitirmos que o velho está moribundo. Mas é justamente porque percebemos, consciente ou inconscientemente, o desmoronamento da sociedade de consumo massificada, pasteurizada, supérflua e idiotizante que a Internet é nossa única bandeira. ${ }^{15}$ 
A tecnologia de conversação que aqui abordamos vem para suprir necessidades materiais dos aglomerados urbanos. É uma ferramenta que a princípio não desempenha uma função cultural, mas seu uso massivo não pode ser desvinculado das modalidades de vivência que o tecido urbano inventa. A técnica, assim, penetra nos interstícios que a cultura vai forjando, nos buracos que a sociedade não consegue tapar ou consertar. Ela penetra nesses vazios, não existe de forma alienígena, por si só.

É estranho que os infortúnios afetivos da vida contemporânea encontrem nos chats um canal de confissão, assumindo as formas mais tacanhas de expressão, repletas de palavras de baixo-calão ou de barbáries gramaticais. Estranho mas esperado, pois são expressões que vivem no ruído, que conjugam o ruído de diferentes maneiras, algumas criativas, outras nem tanto. $\mathrm{O}$ elemento criativo dos chats, afinal, está nos ambientes em que há tensão, no qual o habitat é feito por forças tensionadoras, geradoras de diferença. Não se trata de uma questão lingüística. É preciso ver essas tentativas de expressão como graus, estilos e subtrações de decibelagem distintas, de volumes e texturas contrapostas. São timbres, saturados ou leves, que tentam forjar um espaço, um local, em meio ao ruído infinito da informação, mormente homogênea. Suas cadencias, acentos e vírgulas não são poesia mas pura tensão.

Se a guerrilha, a guerra de minoria, é conforme à essência, é porque elas só podem fazer a guerra se criam outra coisa ao mesmo tempo, ainda que sejam novas relações sociais não-orgânicas. Máquinas de guerra se constituem contra os aparelhos que se apropriam da máquina, e que fazem da guerra sua ocupação e seu objeto: elas exaltam conexões em face da grande conjunção dos aparelhos de captura ou de dominação. ${ }^{16}$

Nhoque: No way, dude.

Fade in:

Gordinho: Nossa, se esse Nhoque me chama de dude na rua, cara...

Nhoque: DUDE.

Gordinho: Eu juro que eu te dou uma surra, Nhoque.

Nhoque: Se vc conseguir, só tentar.

Gordinho: Mano, c tá me acelerando?

Gordinho: Eu passo você, mano.

Nhoque: Se liga, bro. Te colo na goma.

Gordinho: Porra.

* Gordinho desiste da conversa

Fade out.

Usuários que se arremessam o tempo todo. Pode ser só vontade de voar, mas parece mesmo é vontade de movimentação, de se desfazerem.

02:59, AM, Canal \# BIC.

* Nhoque pega porquinho pelos pés e arremessa num campo de excrementos.

Tinny_the_Guy: porrada

* Nhoque pega Tabuas pelo cabelo e soca sua cara medonha na bosta de porquinho.

Gorduxo: Onde está o pilantra?

Gordinho: Preeda! Não me deixe sem ti, querida.

Gordinho: Sono é o caralho, perdão. 
Gorduxo: Eu não respeito a capitalização original dos nicks como esse lorpa acabou de fazer.

Gorduxo: Nem escrevo palavrões com a primeira letra capitalizada. Aliás, gostaria de saber o

motivo que levou o imbecil a fazê-lo.

Gorduxo: Maldição.

Gorduxo: Pensei que fosse o Nhoque, nem olhei a lista de nicks.

* Gorduxo avexado

* Gorduxo dá um tiro de bazuca em Nhoque mesmo assim

preeda: pearl jam é uma merda

Garota_violeta: MERDA É VOCE, FILHO DA PUTA!

preeda: :/

Garota_violeta: que analfabeto

* Gordinho pinta um bigode em Nhoque com uma hidrocor marrom clarinho

* Nhoque continua comendo pipoca parado.

Sr_Pluto entrou no canal \#Ciencia no dia 18 de julho de 2002, uma quinta-feira, procurando por uma saudável operação de terrorismo cultural. Era quase uma hora da manhã, canal lotado, quando o usuário começa a perguntar aos usuários como abrir uma lata de ervilhas sendo canhoto. Diz que com a mão esquerda fica impossível fazer o movimento contínuo e progressivo que rasga o metal, não conseguindo nem sequer enterrar o abridor. "Tenho força na mão direta, sou ambidestro, escrevo com as duas, chuto com os dois pés. Só não abro latas", diz ironicamente. Ao dizer que está procurando por um "método" para abrir a lata, recebe como resposta coisas do tipo "abra com uma faca", "coma a lata junto" e derivados. Depois de lembrar que tais métodos causariam perda no sabor de suas ervilhas, comunica que conseguiu abrir a lata, acumulando vários cortes decorrentes da operação. Segue fazendo perguntas capciosas, mas nenhuma delas maldosa. Termina dizendo que tudo aquilo era um teste para por à prova suas habilidades, "físicas, sociais ou intelectuais", cujo resultado seria utilizado para alterar algo em sua vida, "principalmente a postura". Por hora, "descobri que eu posso abrir uma lata". Então se despede dizendo que precisa ficar bonito para arrumar uma namorada. Fosse isto real, seria uma linha borrada.

08:23:00 PM, externa, \# Canal.

Sapato-preto: Fui expulso da casa.

Sapato-preto: Isso é o que vc pensa.

Gregorio: essa mania de falar com abreviações não serviu para o nick?

Sapato-preto: Não, não serviu.

Gregorio: por quê?

Sapato-preto: Porque não serviu.

Gregorio: por que não?

Sapato-preto: Nem sempre serve.

Gregorio: o que faz com que não sirva?

Sapato-preto: "Com o que não serve"

Sapato-preto: Depende, em geral eu guardo.

Sapato-preto: Ou jogo fora, depende.

Gregorio: por que você usa esse nick?

Sapato-preto: Pq vc não vai escutar um pouco de boa música?

Gregorio: com quem?

Sapato-preto: Com teu cachorro.

Gregorio: desculpe, entendi discutir um pouco de boa música. o que você considera boa musica?

Sapato-preto: O que é boa música?

Gregorio: não, o que é boa musica eu sei: é musica boa. mas qual musica você considera boa?

Sapato-preto: A música de que gosto.

Gregorio: qual você gosta? 
Sapato-preto: Não lembro.

Gregorio: eu lembro.

Sapato-preto: Então vá escutar.

Gregorio: não posso.

Sapato-preto: Então se dane.

Gregorio: não consigo, nem posso, nem quero. todas suas sugestões são inviáveis.

Sapato-preto: Ta complicado, meu caro.

Gregorio: sou-te caro?

Sapato-preto: Claro...

Sapato-preto: Claro que não.

Corte para:

Apodrecido entrou no canal

Apodrecido: Olá, Sr. DAEMON

Daemon: destruction

* Brecht dá boas vindas para Ovo.

Apodrecido: GRATO

Apodrecido: Vim acertar minhas contas contigo.

* Apodrecido is now known as Vovo-Mafalda

* Vovo-Mafalda vim aprontar aqui, agora

Vovo-Mafalda: Mentira.

Vovo-Mafalda: Vou me comportar.

Vovo-Mafalda: Meu problema é com o Natch.

Vovo-Mafalda: Maldito.

Vovo-Mafalda: As veias do meu pescoço intumescem quando eu penso naquele marajá.

Brecht: Estou com vontade de espetar o Vovo-Mafalda e botar na lareira.

Brecht: Só pra ver estourar. Fazer barulhinho.

* Vovo-Mafalda wonders

Vestido_em___veludo: Vovo-Mafalda

Vovo-Mafalda: Öi.

Vovo-Mafalda: Lá vem bronca:(

Vovo-Mafalda: Brecht: Não revelo. E vós?

Brecht: Cigarro super-grandes, BOZO.

Daemon: rubem fonseca é lixo

Daemon: rubens paiva tb

Brecht: E Daemon é um gênio.

Vovo-Mafalda: BRECHT SEU BOSTA

Vovo-Mafalda: É VOCÊ. VOCÊ É O NATCH

Brecht: Cigarro supergrandes, BOZO. ;)

Vovo-Mafalda: EU NÃO TINHA RECONHECIDO

Vestido_em___veludo: hahahahahahahahahaa

Vovo-Mafalda: SEU COCÔ DE CACHORRO MORTO

Vovo-Mafalda: FILHO DE UMA PUTA

Brecht: Tsc, porra, Vovó. De novo?

Vovo-Mafalda: BOSTA HUMANA

Vovo-Mafalda: INSETO

Vovo-Mafalda: FILHO DE UMA PUTA

Vovo-Mafalda: QUERO QUE MORRA AGORA

* Brecht pensa na própria mãe.

Vovo-Mafalda: MORRA APODREÇA SEU AZEDO

Daemon: de brinde vem o canal literatura e toda o lixo que passa por aqui

* Daemon saiu do canal \# literatura

Vovo-Mafalda: Tá feliz agora, desordeiro?

Brecht: Estou um pouquinho.

Brecht: Mas tem um baita buraco por aqui.

Vovo-Mafalda: Leiam o que ele me disse em PVT:

Vovo-Mafalda: Brecht: Vamos sacanear o Daemon

Vovo-Mafalda: Vovo-Mafalda: Bem... eu não sei, Brecht... minha cabeça está confusa...

Vovo-Mafalda: Brecht: \# literatura

Vovo-Mafalda: Brecht: Vamos sacanear o Daemon 
Vovo-Mafalda: Vovo-Mafalda: Bem... eu não sei, Brecht... minha cabeça está confusa...

Vovo-Mafalda: Aí está!

Vovo-Mafalda: Pobre Daemon.

Vovo-Mafalda: Mais uma vítima desse débil mental.

Brecht: Mas que filho de uma puta. Cabeça confusa?

Vovo-Mafalda: Filho de uma puta é você, filho de uma puta!

Vovo-Mafalda: VOCÊ NÃO VALE A MERDA QUE VOCÊ CAGA

Brecht: Ora, ora ora, vejam só quem é que está me chamando de filho de uma puta.

Brecht: Vovó, seu imbecil, eu sei quem é você.

Brecht: Você achou mesmo que tinha me enganado?

Vovo-Mafalda: (reparem no olé)

* Vovo-Mafalda saiu do canal \# literatura

TheKID: Filho de uma puta é você, filho de uma puta...

Vestido_em___veludo: ahahahahahahahahaahaha

Bach: fagocitose

TheKID: Filho de uma puta é você, fdp!

MassinhaDEMODELAR: haha

TheKID: MassinhaDEMODELAR: Filho de uma puta

O usuário acaba desenvolvendo um estilo próprio, tanto de aproximação como de manutenção das relações. A grande vantagem em relação aos contatos pessoais é a possibilidade de experimentação. Se um tipo de abordagem, em princípio, não funcionou, sempre se pode tentar de novo, algum tempo depois, talvez até usando-se uma nova identidade. ${ }^{17}$

A televisão adicionada ao controle remoto é, talvez, a primeira cultura verdadeiramente democrática: sua programação é disponível para todos e totalmente governada pelo que a maioria quer ver, conscientemente ou não. O que é realmente assustador é perceber o que afinal as pessoas querem ver. Não é só o problema da (ausência de) instrução que chama atenção, mas o substrato animalesco do desejo nos programas televisivos. Conforme a qualidade decresce, os hormônios de uma massa indistinta mostram a que vieram: satisfazer a miséria sexual de milhões de pessoas. Puro plutônio enriquecido.

IRC, e a Internet em geral, funcionam de maneira diferente. Todos falam com todos, de forma que a ditadura da massa fica peremptoriamente enfraquecida, talvez inviabilizada. A possibilidade de se atacar um usuário diretamente está sempre presente, conquanto de maneira temporária. Diferentemente da TV, que funciona como uma base de operações torpedeando tudo, a Web e sua particular narrativa opera como uma miríade de batalhões sem comandante, prontos para caçar o que desejam. Nitroglicerina pura.

Billy_the-old: é verdade q o Holder, Sammi e a Geanne tiveram o visto de permanência no canal \# Game negado por serem suspeitos de terrorismo?

Pianola: Ha ha ha ha

Pianola: Cultural, só se for. São células cancerígenas até pro terrorismo.

Usuario_Banido: Vou te mandar um som. O comecinho é ótimo. Dá até arrepio.

louva-loupa: Mande, please.

Usuario_Banido: Não está funcionando. Esse meu DCC tá uma porcaria. Join ICQ.

louva-loupa: Meu ICQ esta uma porcaria. Join the army. 
Um dos traços mais fascinantes nessas aglutinações eletrônicas é a capacidade de transformar uma fala banal na simulação de um acontecimento especial. Ocorre pela potencialização dos usuários em uma força anônima e coletiva, um agenciamento que muitas vezes é atravessado por uma vontade de destruir. Como funciona? A palavra chave que desencadeia a operação verbal de terror cultural varia de Canal para Canal, ou de grupo para grupo. Nos exemplos que agora seguem, aparecem como "bora dominoh" ou "operação mindfuck".

02:37 AM, Canal \# BIC.

* Convidado comemora a anarquia no canal

Aplikativus: Não há o que comemorar.

Ygnes-Satim on: VAMBORA DOMINOH?

* Convidado transforma Aplikativus em um camaleão daltônico

Convidado: Ygnes: só se for agora! *voz de Eri Johnson*

* Ygnes-Satimon borrifa RAID Mata Camaleões Daltônicos em toda a sala!

Aplikativus: Seus idiotas, o mundo é tudo * das criança*, porra.

Aplikativus: Duvido que a Ygnes seja menina.

Aplikativus: Parece mais um poodle rosa.

Fade out:

Nhoque: Ei predeiro, o que é a foto do tópico?

preeda: é pra achar o letrapet

Nhoque: O boto-cor-de-rosa?

preeda: sim. ache-o e concorra a 10000 fireflies

Nhoque: Deve ser aquele balofo de vermelho.

preeda: você quase acertou, Nhoque

Nhoque: Acho que deve ser, então, aquela menino lambendo o pescoço do fulano ao lado, perto do

'Balofo Vermelho'.

Tabuas: Nhoque é mó grosseirao

* Tabuas peida na cara de Nhoque

* Nhoque acende o isqueiro e explode Tabuas.

Nhoque: Sou sentimental, quando encontro amigos as lembranças me consomem e quero então morrer. Fico fazendo cara de entediada depois vou ao banheiro, onde penso em me afogar na

privada. Faço um gargarejo e retorno à mesa bem posuda, com batom retocado. Pouca coisa me atinge.

Nhoque: Ahhh, como sou piegas.

preeda: que porra é essa, Nhoque?

Nhoque: Sou eu, bobinho. E eu sou você mês que vêm.

01:51, PM. Canal \# BIC.

* Gorditos belisca a panturrilha de Adriana

porquinho: SAI FORA MERMAUM

* Apple continua a dedilhar seu piano, pois nada sente

porquinho: ESSAS COXA É MINHA

Apple: penturrilha é embaixo da coxa, ok?

porquinho: penturrilha

Apple: ah, meu

Apple: EU NAO SEI DIGITAR

Apple: VAO TUDO SI AFOGAR COM AREIA

* porquinho se meleca todo

* Nhoque se cala para que porquinho desabroche. Como uma menina.

* Gorditos só observa.

* porquinho pira a cabessa

* Apple com o piercing que reflete a luz do sol 
Nhoque: Qual o problema em MATAR VOCEIS TUDO?

* Gorditos se assusta com Nhoque

* Nhoque tira a camiseta, só de pra mostrar quem manda.

Nhoque: "Embaixador, cale-se".

* Apple sacode a toalha

* Gorditos fica na frente pra tomar ventinho

Nhoque: Coisa mais feia o peito dessas 'mina'. Tudo deformado.

porquinho: tudo GOSTOSO

Gorditos: Passa o link ae.

porquinho: EU CHUPO ESSAS TETA TUDO

Gorditos: Não consegui ver, abrir a página. Acho que tem várias risadas lá me esperando.

Corte para:

Nhoque: Putz, cara. Mas que mulher... E como era linda, e como era burra. Era uma deusa.

* Pebola aproveita que letrapet está olhando pro lado e amarra os CARDAÇOS do tênis dele

@letrapet se apercebe do gracejo em momento tardio e aproveita os minutos de queda livre para

repensar sua vida

* Pebola empurra letrapet do penhasco

Pebola: Tchau!

Pebola: O PhilipDick é sócio do porquinho.

Nhoque: Acho que são *as mesma* pessoa.

* @letrapet, em constante atrito com o vento, se transforma em energia e se torna onipresente

Segunda, 17 de Março, 2003. 00h00,00, Canal \#BIC.

PhilipDick: bora dominoh?

* PhilipDick enfia um palito de fósforo aceso entre os dedos do pé de Nhoque.

Garota_violeta: Philip!

* Garota_violeta sacode pompons

Nhoque: Ora, ora, ora. Então esse Philip é o Gordinho.

* PhilipDick dá um beijo no rosto de Violeta e já entra no palco lendo as atrações do programa nas fichas

* Garota_violeta ruboriza

Nhoque: Ahhh gordinho, não me atice.

PhilipDick: O Nhoque é um intrometido e não tem a mínima classe.

* Nhoque arrrout.

Nhoque: Esse refri tá sem gás. Acabou o gás, dá pra acreditar?

Nhoque: Fui comer azeitonas.

cinzinha: porra

Apple_massumi: porra é o cu da cachorra!

* porquinho exibe um cartaz com um pênis desenhado

cinzinha: VÁ SE FODER

@letrapet: olé

* Nhoque arrrout.

Corte para:

Nhoque: Todo ano o Thinny diz UMA frase correta.

Nhoque: Thinny: ei Sattelite, você não acha que o Gordinho tem inclinação a debilidade?

Nhoque: E ele já gastou os créditos de 2003.

@letrapet: Nhoque é o caminho, a verdade e a vida

@letrapet: Nhoque é o Alfa e o Ômega

@letrapet: Nhoque é o início, o meio e o fim

Gordinho: Nhoque é polêmica.

Gordinho: Nhoque é integração entre os povos.

@letrapet: Nhoque é onisciência

@letrapet: Nhoque é aquele que detém as sete chaves

preeda: Nhoque é menino do rio, calor que provoca arrepio.

Nhoque: CALEM AS BOCA PORRA

Gordinho: Nhoque é um dom, uma certa magia, uma força que nos alerta. Uma mulher que merece

viver e amar como outra qualquer do planeta. 
@letrapet: Nhoque é ela menina, que vem e que passa

* Gordinho coloca um balde cheio d'água equilibrado na porta entreaberta pela qual Nhoque está prestes a entrar

Nhoque: As piadas do Gordinho me lembram as de um velho aposentado, sentado na praça

alimentando os pombos.

@letrapet: Gordinho é o Urbano

Nhoque: "Vamos pescar no fim de semana?"

Gordinho: Ontem mesmo um velho aposentado amarrou meus dois cadarços um no outro e eu caí em cima da pista de bocha.

@letrapet: Gordinho faz a alegria da terceira idade

Nhoque: Vocês acham que o Pianola é desequilibrado. Mas ele é só meninão.

Gordinho: Ah, sim. Eu, particularmente, acho ele muito desequilibrado.

Gordinho: Você não acha, letrapet?

* Gordinho vira-se para letrapet, mordendo a ponta da caneta

* Gordinho oferece uma porção de bitucas de cigarro para Nhoque

Nhoque: Já comi azeitonas hoje, bonitão.

* Gordinho, desagradado com a desfeita, joga a porção dentro da bolsa de Nhoque

* Tabuas se sente cerca de $3 \mathrm{kgs}$ mais leve

Nhoque: lobotomia?

Tabuas: não, outra coisa.

Gordinho: Nhoque é originalidade.

Gordinho: Nhoque é inovação.

Nhoque: Gordinho é um porre, mas tudo bem.

03:48 AM, canal \# BIC.

chiara badalhoca: balzaca dos infernos

Gordinho: MAS VAI TOMAR NO CU, FILHA DA PUTA

chiara_badalhoca: não tem marido pra fazer comida

chiara_badalhoca: filho pra tirar coco da bunda

chiara_badalhoca: Aí fica na Internet

chiara_badalhoca: atazanando humildes galhofeiros

Nhoque sai do IRC: (Então vivíamos na Era da Performance. Exercitavam uma brutal ginástica para sobreviverem)

Os nicks aparecem e depois desaparecem. Aí voltam a aparecer. É uma maluquice. Já fui muitas vezes confundido com outros usuários, desaparecidos, permanentemente ou não. Um usuário aleatório me disse certa vez que se lembrava de mim, que episódios haviam acontecido comigo mas que ele não se lembrava quais, e que para piorar costumava misturar as informações. Quando lhe perguntei qual era a informação sobre esse eu que não era eu (estava novamente sendo confundido), li assustado ele dizer que era alguma coisa que envolvia ou receita de comida, ou automóvel, mas que talvez fossem coisas de bar, como cerveja e cigarro. Nenhum sentido encontrado.

É interessante como podemos ser rapidamente tomados por um outro, que não apenas nos empresta momentaneamente sua história e personalidade como todo um caleidoscópio de afecções virtuais, demandas afetivas, pactos e parceiros de vida. Em um canal com nome de jogo de tabuleiro, um usuário com nick em letras maiúsculas entra a diz coisas irreconhecíveis para mim, como se tivesse não só me reconhecido, mas me descoberto. Depois some. Antes dá o endereço de um blog que exemplifica toda a bizarrice da cena. Descubro depois com quem fui confundido, e também que o usuário que esbravejava 
era o antigo fundador do canal, que depois de casar se mudou para um lugar distante. Essa última informação me pareceu a mais perturbadora de todas, pois raramente se sabe onde os usuários habitam, e mesmo quando moram nas mesmas cidades, raramente se encontram. Fiquei pensando o que deveria significar alguém ir morar num lugar distante, tendo como referência um espaço que elimina além de qualquer distância, o próprio espaço.

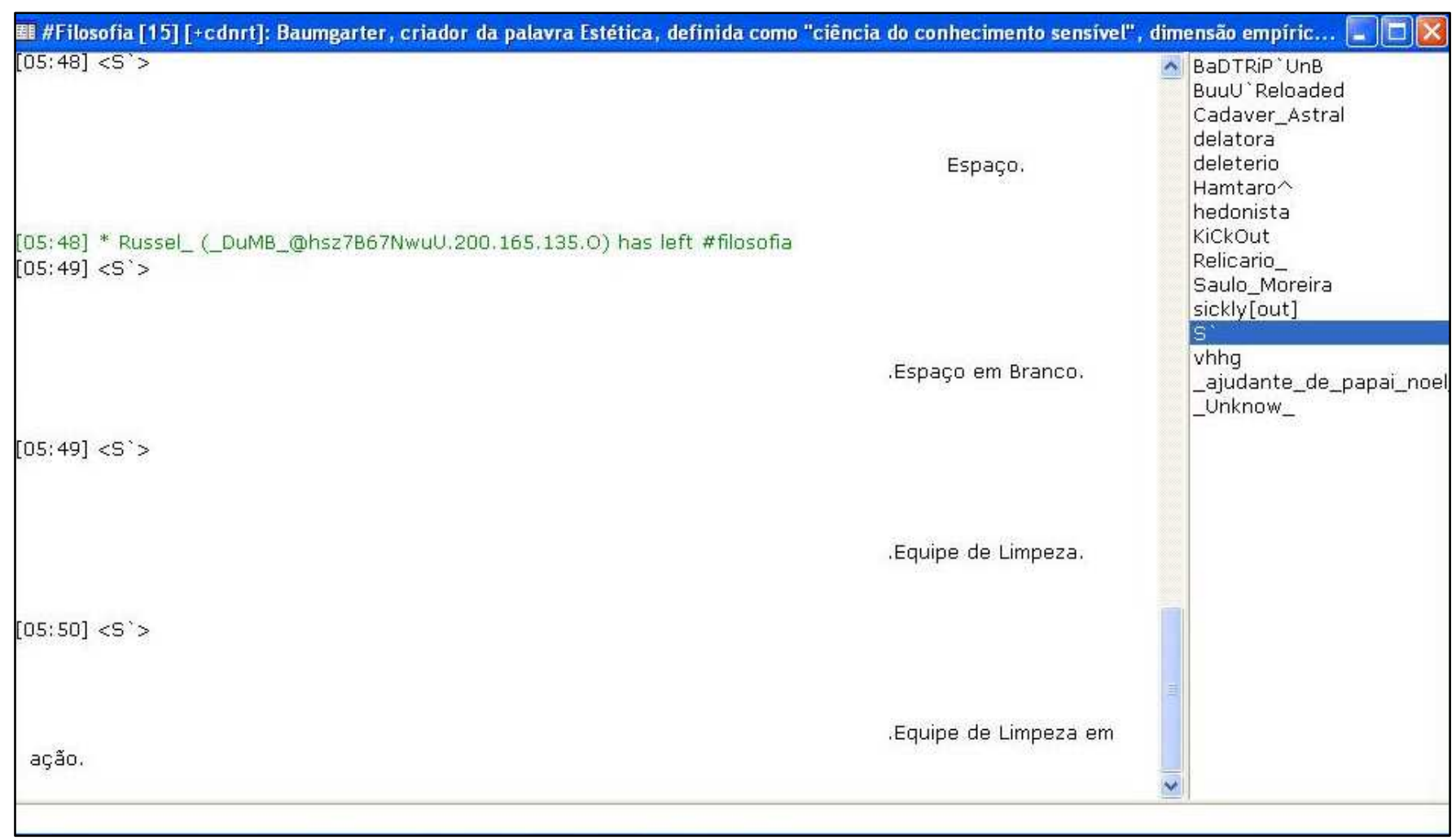

Da mesma maneira, alguns nicks estão sempre no canal, parecem mesmo um Bot (programa que administra o canal). Já vi um destes usuários permanentes ser agredido por outro usuário, de nick feminino, que logo que entrou já começou a brigar. O User/Bot disse-me depois que nunca havia visto a moça. Fiquei curioso por perguntar se este "ver" referia-se a ver de fato, em carne e osso, mas desisti, e tentei questioná-lo sobre como funcionava esse negócio de ficar brigando aleatoriamente, hora com ordem e cronograma e hora com feromônios e adrenalina. Ele me disse que, e deveria ser um matemático ou engenheiro, "a contraposição entre processos lineares e difusos apresenta uma estrutura análoga à oposição entre os processos mentais racionais e irracionais", que por isso brigava, como maneira de equilibrar sua máquina-mental ávida por descargas animalescas. Talvez ele fosse mesmo um Bot: eram quase cinco horas da manhã.

Como usuário mais que antigo, ancestral, revelou que se lembrava do áureo dia em que todos aqueles usuários habitués entraram naquela rede pela primeira vez. Falava num misto de sentimento paternal e desprezo. Disse "É, eu sou um Bot, caramba (...) no primeiro dia que vocês entraram houve até um brainstorm e eu cheguei a achar que era um acontecimento da inteligência conectada. Essa impressão foi paulatinamente se apagando. Hoje ela se tornou uma lousa preta". 
Perguntei por que continuava, então, conectando. Começou a resposta com uma crítica à elite brasileira, em que a própria Internet, por ser utilizada por essa camada da população, refletiria "o triste símbolo da asnice total onde ela vegeta". A razão pela qual voltei a conectar, comenta num devaneio, é que "eu estava ficando inteligente demais, e decidi que precisa emburrecer um pouco, para não perder contato com a realidade". Permaneceu o resto da noite lamentando os diálogos que brotavam, quase por geração espontânea. Gravei o momento em que, se despedindo, se desculpava pelo "espetáculo lamentável que estes elementos portadores de microencefalia desempenharam no canal". Antes de partir, continuei insistindo na conversa, procurando entender a inércia virtual do ciberespaço. Disse-me então em modo privado que nada há a ser feito com estes nicks, pois o usuário de IRC "é inimputável, cara, como os índios, crianças e deficientes mentais. Está na constituição". Seguiu tentando me convencer que para estes usuários - profissionais, talvez - o IRC é uma maneira de empregar o tempo livre. Quando perguntei se dispunham de tanto tempo livre assim, disse-me que tempo livre deve ser gasto com diversas coisas, tais como "conversar fiado, conversar fiado de novo, conhecer as mulheres que valham a pena para conversar fiado". Nenhuma resposta satisfatória. Neste dia, sintomaticamente, o usuário de nick "filho_do_nada", deixou a seguinte mensagem ao desconectar: "Num dia tedioso, para não enlouquecer, se mataram a facadas por não ter o que fazer".

\section{NOTAS}

\footnotetext{
${ }^{1}$ President Muffley, por Peter Sellers. Dr. Fantástico (Dr. Strangelove. Or: How I Learned to Stop Worrying and Love the Bomb). Direção: Stanley Kubrick. USA, Columbia Pictures, 1964, P\&B, son., 35mm, 93 minutos. Roteiro: Stanley Kubrick, Terry Southern, Peter George. Baseado na novela "Red Alert", de Peter George.

${ }^{2}$ Gibson, Willian. Neuromancer. São Paulo: Aleph, 2003. (p.75).

${ }^{3}$ Baudrillard, Jean. O elogio radical da parte maldita. Entrevista realizada por Juremir Machado da Silva. Jornal Folha de São Paulo, Ilustrada, 25/11/1998. Versão integral em http://www.pucrs.br/famecos/10-4.html

${ }^{4}$ Guattari, Félix. Da Produção de Subjetividade. IN: Parente, André. Imagem-máquina: A era das tecnologias do virtual. Rio de Janeiro: Ed. 34, 1999.

5 Antonio Negri tem conduzido toda uma reavaliação das heranças e possibilidades marxistas na contemporaneidade. A questão política, conceituada pelo diagrama da rede e suas disjunções sem centro, também é um dos focos de preocupação permanente do autor. Nas Cinco lições sobre o Império, assim foram trabalhadas: "No mundo atual nenhum Estado-nação, mesmo o mais poderoso, é soberano. Tampouco os supostos inimigos são, eles próprios, Estados-nação; pelo contrário, tratase de redes invasivas, não localizáveis, invisíveis. Hoje, a imagem do inimigo entendido como Estado-nação e o tipo de guerra relativo são mera ilusão, talvez embasada na nostalgia de um mundo que já passou.” (p.78-79). Na página 82, complementa:
} 
"Se agora pertencemos a um mundo onde existe um único poder soberano, não um Estado-nação mas uma forma global de soberania que não possui exterior, então cada guerra é necessariamente uma guerra civil, no sentido de que é um conflito interno em uma única sociedade que se tornou global. As duas perspectivas concorrentes, molar e molecular, se reapresentam aqui como interpretações heterogêneas da guerra civil. Segundo a teoria molar, uma guerra civil se caracteriza pelo conflito entre duas potências virtualmente independentes e soberanas. Em nossos dias, a teoria de Samuel Huntington sobre o choque de civilizações propõe uma perspectiva molar desse tipo: blocos de civilizações potencialmente soberanas e territorialmente independentes combatem entre si pela autonomia e hegemonia dentro de um sistema global. Uma perspectiva molecular, pelo contrário, propõe uma imagem muito diferente da guerra civil. A guerra civil molecular se caracteriza por estruturas que se sobrepõem e estão em conflito em um espaço comum, ao longo de múltiplas frentes variáveis. Uma vez mais, a elaboração molecular se aproxima melhor da realidade." Encontra-se ainda no final do livro (p.191) tais considerações sobre a estética e a operacionalidade da guerra na contemporaneidade (grifos do autor): "A guerra pós-moderna é algo menos que a guerra moderna, mas é também algo mais do que a polícia moderna. A guerra pós-moderna tornou-se - monstruosamente - uma espécie de máquina produtora do social." Negri, Antonio. Cinco lições sobre o Império. Rio de Janeiro, DP\&A, 2003. Ver também, a esse respeito: Negri, Antonio e Hardt, Michael. Império. Rio de Janeiro: Record, 2001.

${ }^{6}$ Baudrillard assim comenta essa relação: "O terrorismo atual não é produto da clássica história de anarquismo, niilismo ou fanatismo. É pelo contrário um parceiro contemporâneo da globalização. Para identificar suas características principais, é preciso fazer uma rápida genealogia da globalização, particularmente do seu relacionamento com o singular e o universal". No original: "Today's terrorism is not the product of a traditional history of anarchism, nihilism, or fanaticism. It is instead the contemporary partner of globalization. To identify its main features, it is necessary to perform a brief genealogy of globalization, particularly of its relationship to the singular and the universal." Baudrillard, Jean. The Violence of the Global. CTheory - Theory, Technology and Culture. vol. 26, No 1-2, artigo 129, 20/05/2003 Editores: Arthur e Marilouise Kroker. Traduzido para o Inglês por Francois Debrix. Disponível em: http://www.ctheory.net/text_file.asp?pick= 385 e também disponível em Espanhol, La Violencia de lo Global, na tradução de Carlos Silva em http://www.ctheory.net/text file.asp?pick=386\#_edn1. Angel Jordan, do CERT (Computer Emergency Response Team, Universidade Carnegie Mellon), em uma conferência recente afirmou que o ciberterrorismo é uma realidade, e que a Al Qaeda usa regularmente computadores para passar adiante seus planos de operação. Segundo Jordan, Osama bin Laden já afirmou que as infraestruturas de informação e finanças dos EUA são alvos potenciais de ações terroristas. - O ataque ao World Trade Center teve um ciber-impacto na infra-estrutura financeira, embora ela não fosse o alvo original. Jornal O Globo, Informática ETC. 22/03/2004. Disponível em: http://oglobo.globo.com/jornal/suplementos/informaticaetc/141271593.asp. Não por menos, a reação americana ao descentramento não foi apenas um recrudescimento militar-armamentista, mas também mais uma superrede. O pentágono já começou a construir uma segunda rede de proporções mundiais que poderia visualizar qualquer quadro em movimento, de todos os inimigos estrangeiros ou potenciais ameaças: "um ponto de vista de Deus", como assinala a reportagem do New York Times sobre a assim chamada GIG (Global Information Grid ou "Grade de informação Global”) e a "Nova Teoria da Guerra": "Os defensores dizem que computadores em rede serão a arma mais poderosa no arsenal americano. Unindo armas, inteligência secreta e soldados em uma rede global - o que chamam de guerra net-cêntrica - mudará, segundo eles, as forças armadas da mesma forma que a Internet mudou os negócios e a cultura. 'Possivelmente, o elemento mais transformador em nossa força', disse o secretário de Defesa, Donald H. Rumsfeld, 'não será um sistema de armas, mas um conjunto de interconexões'. As forças armadas americanas, formadas para combater países e exércitos, agora enfrentam inimigos sem Estado e sem jatos, tanques, navios ou quartéis-generais centrais. O envio instantâneo de inteligência secreta e estratégias para soldados em batalha tornará, em teoria, as forças armadas uma força mais rápida e mais forte contra um inimigo sem rosto". O programa de guerra net-cêntrica está orçado em US\$ 120 bilhões, mas o Pentágono estima em US\$ 200 bilhões ou mais os gastos em equipamento e software para a rede de guerra, só na próxima década. Nos termos de Art Cebrowski, diretor do Escritório de Transformação da Força do Pentágono, "o que estamos realmente falando é de uma nova teoria de guerra", em consonância com Linton Wells, do Departamento de Defesa, ao dizer que os princípios net-cêntricos estão se tornando o "centro de gravidade" dos planejadores de guerra. Ver: Pentagon Envisioning a Costly Internet for War, por Tim Weiner. The New York Times, 13/11/2004. Disponível em: http://www.nytimes.com/2004/11/13/technology/

"O novo terrorismo, que abole os campos definidos de batalha, faz o inimigo brotar do próprio uso dos objetos cotidianos. Quem poderia imaginar que um avião civil pudesse ser transformado em arma mortífera? As armas de destruição em massa não se filtram pelo ar, pela água e pela alimentação? Note-se que isso só foi possível porque o desenvolvimento tecnológico junta peças cujo elo pode ser facilmente transformado. $O$ hacker não ameaça redes de computadores nelas introduzindo vírus durante seu pacífico funcionamento? É como se a segunda natureza em que vivemos, dominada pela tecnologia, trouxesse em si mesma um potencial de destruição, como se as catástrofes brutas da natureza primeira pudessem ser projetadas para o mundo tecnologicamente conformado." Giannotti, José Arthur. A fibrilação da guerra e da paz. Jornal Folha de São Paulo, Caderno Mais!, 18/07/2004, pág. 11.

${ }^{8}$ Pronunciamento sobre a Al Qaeda do diretor da CIA, George Tenet, ao Senado norte-americano. Washington File, por Merle D. Kellerhals, Jr. 19/03/2002. Disponível em:http://terrorismo.embaixadaamericana.org.br/?action=artigo\&idartigo=515. Também em: Fotos y datos inéditos del 11 S: la búsqueda de la "verdad oculta". Europa Press, disponível em: http://www.planetadeagostini.es/noticias\&id=162927\&s=1; Captura de celula terrorista que asesino 35 personas en atentados en universidad hebrea, café Moment y otros, 22/07/2002, vol. 3, no 31, disponível em:http://www.jafi.org.il/agenda/ spanish/index31-2.asp. O site Arabic News reporta da mesma maneira a formação de grupos de combate pela Jihad Islâmica e pelo Hamas, que em Ein al-Saheb, Síria, estavam treinando mais uma das assim chamadas células terroristas (to form what it called "terrorist cells"). Al-Jihad denies bases outside Palestine; Israel threatens more attacks on Syria. Arabic News, 10/06/2003, disponível em: http://www.arabicnews.com/ansub/Daily/Day/031006/2003100606.html. 
9 Ver a respeito a matéria Omnia: Sorpresas del Kamikaze. Vanguardia, s/d. Disponível em: http://srv2.vanguardia.com.mx/hub.cfm/FuseAction.Detalle/Nota.322606/SecID.43/index.sal

${ }^{10}$ Entre os coletivos de arte no Brasil, podemos destacar, no Rio de Janeiro, o "After-Ratos": os ratos estão em todas as partes; "Rés do Chão": criar algo que possa ser discutido, mas nunca entendido pelo olho controlador; "Atrocidades Maravilhosas", "ogrupovapor": antiteatro em relação ao circuito artístico em geral, busca de novas teatralidades, e o "RRADIAL". Em São Paulo: "Bete Vai à Guerra", "Formigueiro", "Los Valderramas", "M.T.A.W": Movimento Terrorista Andy Warhol e o "Núcleo Performático Subterrânea". Em Porto Alegre: "Flesh Nouveau!": Trepe nas ruas - bebedeira desenfreada, hábitos gratuitos e a cópula pela cópula e o "Laranjas". Em Goiânia: "EmpreZa" e "Valmet": Fazer intervenções rurais, buscando uma intervenção artística na paisagem rural e imponente do cerrado e dos personagens desse espaço, tais como porcos, cabritos, vacas, árvores, regos de água, pessoas. Em Fortaleza: “Transição Listrada": A cidade não como um espaço de exposição, mas como um lugar próprio; em Macapá: "Urucum”: Os catadores de orvalho esperando a felicidade chegar. Há também grupos em Recife ("Camelo”), Brasília ("Entorno"), Belo Horizonte ("GRUPO”), além dos conhecidos "A.N.T.I. Cinema": deixar acontecer, resgatar as coisas boas da vida; "A Revolução Não Será Televisionada": Um guerrilheiro urbano fictício que utiliza a arte como arma e o "Rejeitados", que se autoproclama o Coletivo de coletivos.

${ }^{11}$ No final de 2003, o metrô de Paris foi tomado por um movimento contra a propaganda e a poluição visual na cidade. Defendendo a retomada do espaço público perdido e atacando a mercantilização da vida, os coletivos fazem uso da Internet para se contatarem. A operação, segundo a Agência CartaMaior, é uma guerrilha urbana que se faz pela sarcástica intervenção em outdoors e demais visuais publicitários. Cruzes negras, desenhos, colagens, grafites, e demais pichações procuram alterar a mensagem publicitária, conferindo-lhe um caráter anticonsumista, como "publicidade é droga pesada", "sirva-se, consuma, pague", "mercadoria por toda parte, poesia em nenhuma" ou mesmo "Feliz Bordel!", em contraposição ao "Feliz Natal!". O ativismo contrapropaganda tornou-se regular, organizado pelo coletivo "Stopub". O saudosismo destes guerrilheiros urbanos é ricamente documentado em seu manifesto, que acusa a publicidade de destruir os "espaços públicos, a rua, a televisão, nossas roupas e nossos muros", propondo sua retomada "através de um gesto coletivo e alegre de protesto. Em face à ofensiva capitalista, declaramos guerra contra esse tipo de totalitarismo e atacamos seu combustível: a publicidade". O a-pub, outro antigo grupo do movimento faz conjecturas em seu manifesto: "Não pretendemos mudar o sistema, mas a emergência de uma mídia alternativa particular está a caminho". Guerrilha antipublicidade invade Metrô em Paris. Agência Carta Maior, 08/01/2004. Disponível em: http://agenciacartamaior.uol.com.br/agencia.asp?coluna=reportagens\&id=1208

12 “O engajamento político deixa de ser a tentativa de mudar a sociedade ou os homens para ser o ato de programar (pela tecnologia) ou desprogramar (pelo terrorismo) o campo social relacional. (...) $\mathrm{O}$ fato é que processamos o percebido como sendo realidade, quer dizer, não vemos em nossa vida um movimento que altera realidades mas, antes, uma tendência de realizar possibilidades dentro e em torno de nós." Marcondes Filho, Ciro. O Princípio da Razão Durante. Trabalho de circulação restrita, 2005.

${ }^{13}$ Alexandre Vogler, do "Atrocidades Maravilhosas", organizou em 2001 um evento que chamou de "Zona Franca", espécie de ocupação artística independente, sem curadoria, regras e que, apesar do apoio da Fundação Progresso, se dizia independente. Nos termos do artista: "Nós convidamos os artistas dizendo assim: "tudo o que você não pode fazer em uma galeria, você pode fazer no Zona Franca', e a ocupação resultou numa grande desordem de anarquistas apresentando trabalhos aleatoriamente." A Explosão do A(r)tivismo. Jornal Folha de São Paulo, Mais!, 06/04/2003, (p.4-9).O coletivo carioca "Rés do Chão" funciona como um espaço autônomo de criação. Segundo Artur Barrio, seu idealizador, trata-se de "uma prática que libere nosso poder e que transforme nossas vidas através do que criamos espontaneamente e sem nenhuma idéia do resultado. É simplesmente começar a chegar e sentir e interagir com os outros para criar 'situações' baseadas no que cada pessoa está fazendo no momento (...) para fornecer um novo modelo de significação produzido ativamente, e não passivamente recebido (isto é, institucionalmente); e criar algo que possa ser discutido, mas nunca entendido pelo olho treinado e controlador, algo sem potencial comercial, mas de valor além de seu preço, que depende da situação, não do estilo ou conteúdo." Pode-se conferir a íntegra do Manifesto em: http://www.resdochao.hpg.com.br

14 "Mantenha a tribo toda em movimento, mesmo se for apenas dados na Web... A 'máquina de guerra nômade' conquista sem ser notada e se move antes de o mapa poder ser ajustado". No original: "Keep moving the entire tribe, even if it's only data in the Web... The 'nomadic war machine' conquers without being noticed and moves on before the map can be adjusted." Bey, Hakim. T.A.Z. The Temporary Autonomous Zone: Ontological Anarchy, Poetic Terrorism. New York: Autonomedia, 1991. (p.102).

15 "É da natureza dos humanos ser incapaz de entender as causas, tratamos da forma a despeito de buscar suas origens. É exatamente porque somos drogados pelas aparências que deslizamos na superfície. A Internet não é grande coisa mesmo. É apenas uma estrutura. Então achamos que, ao povoar a estrutura de objetos e idéias, somos capazes de materializá-la. Achamos que, ao rechear a rede de sites, justificando torpemente suas existências através dos mais variados argumentos viscerais ou projetivos, estamos entendendo sua força real. A Internet não é nada, se não entendermos quais são os desejos, as fantasias, os sonhos da sociedade e dos humanos. A Internet é somente um laboratório. Não é uma mídia de massa e tampouco é uma mídia um para um. A Internet não é o correio e muito menos o telefone. Não é um shopping center, nem um jornal, nem uma TV, nem um parque de diversões. Se for só isso, não precisamos dela. Pois a Internet é tão-somente uma plataforma de expressão dos humanos. Qualquer iniciativa que pretender, de forma artificial, limitá-lo, enquadrá-lo, agrupá-lo e principalmente calá-lo é pequena e efêmera". Alphen, Fernand. A Internet não é nada. Digestivo Cultural, 24/10/2003. Disponível em: http://www.digestivocultural.com/colunistas/coluna.asp?codigo=1211

${ }^{16}$ Deleuze, Gilles. Guattari, Félix. Mil Platôs - Capitalismo e Esquizofrenia. São Paulo: Editora 34, 2000. Vol.5. (p.110)

${ }^{17}$ Storch, Léa Waidergorn \& Cozac, João Ricardo. Relações Virtuais: O lado humano da comunicação eletrônica. Petrópolis: Vozes, 1995. (p.13) 


\section{ÉDIPO E MAQUINISMO ESQUIZO}

estrutura de subtópicos

1. introdução

2. édipo \& neurose

3. romper édipo; fluxo

4. esquizo

5. sexualidade máquina

\section{INTRODUÇÃO}

Os chats são canais seriados para exibição do Eu (self). Tabernáculo da comunicação no novo milênio, traz consigo uma miríade de questões imanentes à contemporaneidade. Relacionamentos por palavras, traduzir em palavras uma realidade eminentemente imagética. Diferentemente das praças, clubes ou bares - lugares proeminentes na sociabilidade moderna, o ver-se sem se ver desanuvia uma inesperada reprimenda de fluxos não edipianos, modernos e neuróticos. Não há harmonização entre as lacunas geracionais, há catalisação e agenciamento delas. O flâneur continua flanando, enquanto o zapeur desliza esquizofrenicamente por fluxos invisíveis. Em que lugar isso tudo acontece? Dentro da sua cabeça, é claro.

São adolescentes, pré e pós-adolescentes buscando satisfação afetiva e sexual dentro das salas de chat. Nesse período, é natural se desejar uma vida diferente, alargando os horizontes de referência. Ocorre que o fato desse período estar se entabulando numa rede rizomática de fluxos, os agenciamentos subjetivos podem se descolar de vez da contingência edipiana, moderna e neurótica.

Na adolescência, a contestação a valores e figuras idealizadas que foram internalizadas durante a infância é parte do processo de crescimento. Começa-se a desejar outros modelos de amor e de afeto que não o dos pais ou dos círculos a que pertencemos. Tal processo de abertura é fundante na formulação do próprio objeto sexual e afetivo. A novidade é sua introjeção no universo cibernético.

O chat é um palco para ensaios de todo tipo. Poder treinar suas fantasias e capacidade de aproximação, convencimento, sedução. Para um adolescente, é espaço para começar a desejar e ser desejado, sem o emaranhado infinito de códigos da interação face a face. No cybersexo, espécie de masturbação a dois, o adolescente vivencia a fantasia compartilhada, interagindo estímulos comuns. Desde o começo funciona como uma rede, desde o começo as trocas e compartilhamentos são $P 2 P$, pessoa a pessoa. Como não se enxerga o interlocutor, a idealização impera numa formação subjetiva em que só temos, vivemos e conversamos, com o espelho. A alteridade é radicalmente - enquanto nós mesmos - indecifrável. 
Não são joguinhos adolescentes e insignificantes, vaivens de solidão apartados da dinâmica cultural. Pois a cultura não é exterior aos agentes nem está fora da pulsão desejante. Pelo contrário, a cultura é o lugar onde o simbólico e o pulsional interagem, sendo seus jogos e regras mutantes. A cultura, assim, não pode ser entendida como um universo plenamente domesticado: sendo parte constituinte da subjetividade, a pulsão encontra nos objetos do desejo a presença inesperada do outro. Pulsões precisam de joguinhos, de campos de ensaio para que não se tornem um bloco fechado de certezas aterrorizantes ${ }^{1}$.

Já é outro o agenciamento subjetivo. Não há família nuclear no universo silícico dos bits. Não há pai, nem mãe, tampouco tio. O que há é uma horda de unidades de desejo, pouco afeitos aos módulos modernos de troca. Psicanaliticamente, é o embate entre funções paterna e fraterna.

Durante a modernidade industrial, o período de Freud, o mito da fundação da cultura tinha um efetivo compromisso com a figura paterna. $\mathrm{O}$ desenvolvimento psicológico infantil tinha um nítido paralelo com a família nuclear e patriarcal, sendo seus desvios, suas patologias e sintomas, naturalmente desmembrados desta formação. Fixações, recusas, transgressões e compromissos sempre guardavam relação significante com o pai. Espécie de pirâmide do significado, o pai era estrutura e estruturante da sociedade $^{2}$.

Acontece que a permanência desta função simbólica se ancorava num poder concreto que lhe conferia realidade. Pai de família simbólico mas igualmente real. Tão real, visível e incontestável que estruturava todas as ordens sociais - imaginárias e simbólicas: família, religião e Estado. Todas as aglomerações se voltavam ao pai fundador: heróis nacionais, mártires das causas, líderes de grupos, representantes de organizações, governadores ou prefeitos. O Édipo freudiano, assim, era alicerce para uma constatação tanto teórica quanto imediata, pois remontava a uma sociedade em grande parte funcionalizada pelas famílias nucleares tradicionais, de um lado com a presença garantida da figura paterna, de outro, na presença absoluta do Estado como guia para todas as verdades e carências enunciáveis.

Os anais da Modernidade industrial também narram a história da decadência da supremacia paterna. A primeira metade do século XX, de industrialização ininterrupta e burocratização do Estado, complexifica os extratos sociais de forma a funcionarem sem um único centro de decisão. A burocracia, efeméride da perversidade organizacional, foi o carrasco de uma ordem de decisões consistentemente unitárias ${ }^{3}$. A Teoria Crítica, que se desenvolveu nas décadas de trinta e quarenta, orientou a primeira revisão sistemática da presença paterna tanto nos órgãos gestores e decisórios quanto no imaginário social. Para ela, o desenrolar do Capitalismo trouxe no seu âmago a indistinção entre agentes e generalizou a valoração individual: pasteurização fálica. A Lei e a Ordem foram pulverizadas e massificadas, não 
carecendo mais da co-presença do Pai como agente simbólico e físico. A brutalidade desta ruptura, e a impossibilidade de afirmar uma identidade frente a ela é a própria história da modernidade, de que Kafka é ao mesmo tempo o maior algoz e a maior vítima ${ }^{4}$.

Da mesma forma, a passagem da modernidade à pós-modernidade marca o derradeiro golpe à instituição paterna. O que a industrialização começou por desmembrar, a informatização desmontou de vez. O flâneur moderno passeava afagando lentamente a paisagem social. O zapeador, sujeito fragmentado, opera por cortes, por colagens. Da mesma forma que para Freud a histeria constituiu a psicopatologia mestra para cunhar a psicanálise, na pós-modernidade estes casos se mostram tão raros quanto comuns os de depressão, de impotência, de ausência de sentido na vida, de solidão ${ }^{5}$. Do recalque às pulsões sexuais genitais para sua reprodução a-significada em todos os lugares. Se para a histérica o sexo não podia ser pornográfico, para o depressivo o sexo não pode ser erótico. O signo só faz correr.

Mas antes que, através dos joguinhos eletrônicos de troca, se declare o fim das economias libidinais, é preciso lembrar que a única ameaça se encontra no desinvestimento da cultura, na evacuação deste espaço como campo de agenciamento subjetivo. Isto não quer dizer apenas relegar a cultura a uma importância menor, mas também deixar de procurar os lugares em que estes investimentos estão se dando. A comunicação, esse movimento vivo da Cultura, serve como anfitrião para a apresentação destes estranhos lugares do desejo. Quando a diferença bombardeia a cultura, a forma de se relacionar com ela pulula.

Cultura não como piscina de resíduos tóxicos da miséria neurótica, mas como elemento instável e oxigenador, instância vital de onde pode florescer um diverso tencionado, e não subjugado. Conjunto de experimentos contingentes, criados pelos interessados conforme a experiência demande. Cultura é, assim, um espaço movediço e transicional que não se cristaliza, que se constrói pelo reconhecimento que os pares delegam a artifícios criados por outrem e cujo significado é entendido sensorialmente ${ }^{6}$.

\section{ÉDIPO \& NEUROSE}

Jurandir Freire Costa permanece questionando o por quê, então, da contínua obsessão em se cultivar o Pai, em se descrever sua presença e sua necessidade ${ }^{7}$. A função fraterna não é, nem poderia ser, condição última para a paz social. Melhor dizendo: só o é para a paz edipiana, neurótica. Mas é justamente esta condição que trataremos de debater melhor neste capítulo. 
Hakim Bey é outro autor que aponta para o desmanche da agregação familiar. Em T.A.Z., sua bíblia para atos de rebeldia, ressalta que forças invisíveis trabalham para resgatar o bando frente aos grêmios de publicidade edipiana. Bey quer romper com a tradição da neurose e instalar a ordem anárquica da subjetividade pirata. Em seu devaneio utópico, aponta pertinentes fendas desta sociedade por ele denominada de "pós-espetacular",

Em meio a isso tudo, o que nos parece fundamental ressaltar é que o inconsciente freudiano é inseparável de uma sociedade presa à modernidade, às tradições falocráticas e suas subjetivações congeladas. Categorias estanques de vivências calculadas. As erupções da contemporaneidade, pelo contrário, demandam toda uma modelização outra, quiçá original, sintonizada com as novas práticas sociais e estéticas que pipocam no baú de signos que é a cultura. Desvalorizar o sentido destas construções é esvaziar a imagem do Eu que se oferece, numa espécie de operação mercenária para instalar o opaco, o confuso.

Mas sem tomar Édipo como uma categoria imóvel e universal. Há variações inúmeras que tendem a expressar as diferenças culturais dentro do próprio embate edipiano. Em Totem e Tabu, Freud claramente sugere que há pelo menos duas formas macroculturais que emergem do embate edipiano: paternalismo e fraternalismo. Em vista da variedade e complexidade de sistemas macropolíticos, é razoável que uma maioria tenha nas relações edipianas uma complicação teoricamente mal-resolvida. Freud não desenvolve totalmente esta idéia, deixando o campo do desejo como ator político e social de escanteio. Sobretudo, a forma pela qual as macroestruturas interagem com as variações e embates edipianos ficara eminentemente suprimida. $\mathrm{O}$ caso da função fraterna não é muito diferente.

A estrutura da função paterna passa pelo totem tribal, que proíbe um membro da tribo de dormir com um membro do mesmo totem, enquanto permite que se durma com qualquer membro de outro totem ${ }^{9}$. A função paterna não precisa ser necessariamente exercida pelo pai simbólico, mas pelo pai imaginário. O estranho em nossa cultura é que ambos estiveram predominantemente conjugados. Da falência da função paterna e a emergência da função fraterna, o que causa estranheza não é a diferença para a nova função no imaginário, mas sua operacionalidade simbólica.

Como fora dito, parece-nos bastante claro que a autoridade paterna esteve num constante despedir-se no século que passou. Entrementes, isso não implica que a função paterna acabou, encerrando sua necessidade. Mesmo nos canais de conversa aqui observados, ou nas voláteis tribos que se fazem e se desfazem sob os auspícios de exclusão e identidade, é patente a procura por novas formas de autoridade paterna, atravessando desde as manias místicas de orientalismos até as pragmáticas coadunações de 
grupos locais. São formações que pedem claramente pela presença de uma função fraterna, ainda que a operacionalidade dos irmãos muitas vezes flerte com a ruptura da autoridade una, da voz absoluta.

DeMause é um autor que também rejeita a função paterna, flertando com formas não-freudianas de subjetivação e identificando a função paterna com a tirania. Melhor dizendo, o extrato patriarcal não apenas como a Lei do Pai, mas como uma mistura de compaixão e domínio, quintessência do patriarcalismo. Nesta ótica, o pai é quem necessariamente deve tomar conta da família, e é exatamente por isso que se pode afirmar estarmos vivendo em tempos pós-patriarcais. A função fraterna, tal como Maria Rita Kehl, Jeol Birman e Jurandir Freire Costa a denominam, ou a irmandade dos órfãos, tal como prefere grafar Juliet Flower MacCannell, é regulada por um regime de irmãos, fraterno - o que não significa que sejam necessariamente menos autoritários ou repressores. Mas sim que tais irmãos atuam como o antigo pai, no que tange a amplitude e autoridade da ação, muitas vezes, no entanto, sem a responsabilidade e preocupação próprias ao poder parental. Aqui, não se trata de nostalgia para com o Pai, mas de reconhecer que a formação patriarcal não encerra toda a dominação e opressão. As formações autoritárias e repressivas, pelo contrário, se dão em nuances imperceptíveis, que serão tratadas no capítulo seguinte.

Assim, é importante lembrar que o colapso da função paterna não é necessariamente um veio libertário, mas pode nos levar à reprodução desta ausência pelas formas mais autodestrutivas possíveis. Isto porque compreender a função paterna como exclusivamente sem sentido é uma boa fórmula para o estabelecimento insuspeito da repressão generalizada. Ou seja, lembrando Lacan e suas categorias conceituais clínicas, sem o Nome do Pai há apenas perversão e psicose ${ }^{10}$.

Por isso, quando falamos na função fraterna, não a entendemos como excludente do Nome do Pai, nem como uma conjunção de subjetividades eminentemente livres. Trata-se antes de uma maneira distinta de costurar o simbólico e o imaginário, que não se resume aos enquadramentos da ortodoxia freudiana. Função fraterna, aqui, não é a morte do pai, mas uma ressignificação do mesmo. Esquizo, aqui, não é a esquizofrenia decorrente da ausência do corte simbólico, mas toda uma economia libidinal que não se exerce sob os auspícios da política neurótica ${ }^{11}$.

Pensando a ortodoxia: Parece-nos que Freud está certo quando insinua que Édipo ou a triangulação sexual familiar mente na raiz do inconsciente. Simplesmente porque aqui optamos pela categoria deleuzeana de desejo, que não admite estruturas estanques na psique. Não exatamente optar. Ocorre que as categorias freudianas não apresentam validade em conjunções específicas da subjetivação. Quais sejam: as do movimento. 


\section{ROMPER ÉDIPO; FLUXO}

Com isso, não se trata de negar Édipo como triangulação decisiva na formação da psique. Trata-se, pelo contrário, de compreender que esse processo também foi agenciado de outras maneiras ${ }^{12}$. Conjunta e opostamente a Édipo, numa convivência paradoxal. Não há nada de errado no pacote de subjetividade que estabelece a família nuclear: pai, mãe e filho, numa tríade feliz de produção subjetiva. Ocorre apenas que este padrão perdeu sua proeminência e não podemos invocá-lo como modelização única da individuação contemporânea.

Como dito, a formação edipiana foi paulatinamente desconjuntada pelos processos de desagregação capitalista. Industrialização como desenraizamento e, piorando, globalização como reordenação. Se a perda do monopólio edipiano nos agenciamentos subjetivos foi também articulada por meio dos media que criavam agregações contrárias, deslocamento de toda sorte e micropolíticas que não bradavam por Édipo -, a Internet e suas ferramentas de descentralização radical oferecem um golpe derradeiro e certeiro nesse um modo de vida que não oferece grandes movimentações físicas, espaciais e afetivas para o indivíduo.

Isso porque Édipo é uma estrutura de segurança e estabilidade. É certeza diante dos deslocamentos subjetivos, dos descaminhos da convivência e da intersubjetividade. Édipo quer padrões fixos, quer papéis sociais claramente marcados e delineados com precisão. Dissonância e imprevisibilidade não são desejáveis. Entretanto, não é uma modelização necessariamente conservadora, mas uma modelização Moderna ${ }^{13}$, no sentido de inteira, total, um bloco simétrico que não admite grandes contradições.

Isso é tudo o que a contemporaneidade não pode fornecer. Aos investimentos unicamente edipianos no edifício da pessoalidade contemporâneos, o resultado é, nos mais das vezes, dor e sofrimento. A histeria como patologia mestra no século XIX e início do XX desaparece no desenrolar do XX e dá lugar às novas obsessões do $\mathrm{XXI}^{14}$ : falta de sentido na vida, vazio, fraqueza, depressão, pânico, descontentamento intermitente, falta de autonomia e determinação, incapacidade de responder às demandas afetivas, desinteresse pela ordem social. Em suma, afastamento do desejo. O resultado é o show de apatia e medo generalizados que presenciamos com mórbido alheamento.

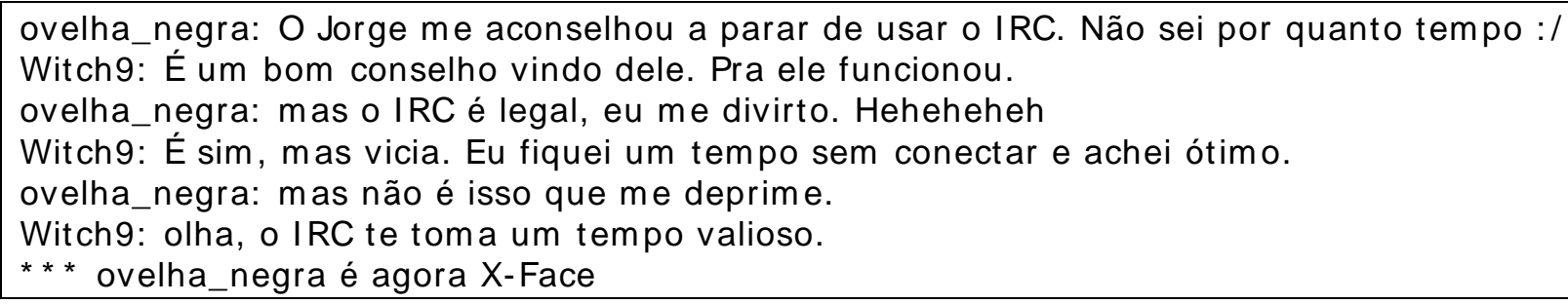


Witch9: você pode arrumar milhões de desculpas para justificar sua depressão... Nesses casos

ficamos insatisfeitos com nós mesmos e procuramos fazer duzentas coisas pra não ter que ficar se

aturando. O IRC é uma delas....

Witch9: É difícil agente ficar só. Somos insuportáveis... passamos a vida toda fugindo de nós

mesmos... por isso você se deprime. Sei como é depressão.

Isso porque bradar Édipo nestes dias é bradar por uma longínqua ordem inviável. Exigir que as agregações e os relacionamentos atuais funcionem sob o auspício de Édipo é apostar numa empresa falida, impossível de responder positivamente frente às formulações de um dia-a-dia esquizofrênico, de trocas imateriais e de desenraizamento obrigatório. Dissemos que os media forneceram a base material para a ruptura do padrão único de agenciamento, resta dizer por que a Internet e os media descentralizados e de sistematização fragmentária servem ao ofício da desterritorialização.

A função entre eles é menos óbvia do que parece, pois não se trata apenas de descentramento e de deslocamento temporal e espacial do agregar-se, do conviver. Não se trata unicamente da ruptura no padrão político de consumo. A mudança também se dá no padrão macropolítico de produção, que também é acêntrica e não respeita os ditames modernos do Estado-nação, das fronteiras e da delimitação fixa e permanente. Do ponto de vista político, a estrutura da Internet é um problema pelo qual juristas e legisladores quebram a cabeça e não vêem nenhum oásis pela frente ${ }^{15}$.

Do ponto de vista micropolítico, podemos ver Édipo se esfacelando em uma miríade de formas de viver, maneiras de querer a vida. Não falo apenas de formas de consumo, mas práticas e atitudes de convivência. A emissão de ondas pela TV, rádios, cinemas, jornais, e demais media do século XX marcam a difusão de padrões de existir múltiplos, e em larga medida, contraditórios. Zapping. Mudo de canal porque este me é cansativo, repetitivo e maçante. Procuro por agenciamentos que me coloquem fora de mim, naquele Eu que procuro ser. Tais media modernos são, essencialmente, máquinas de agenciar. E esse agenciamento pode ser tão conservador quanto a pregação do mestre das verdades submersas.

Foi assim que, a partir dos anos 50, a psicologia social intensificou o trabalho sobre os usos de desusos das "máscaras"16 nos ambientes sociais. Essas máscaras consistem na adaptação de identidades que alteram nosso ser social, numa prática implicitamente estranha. O difundir das "máscaras" e dos padrões de comportamento pelos media, especialmente pela TV, determinou um sério questionamento sobre o que acreditávamos ser e o que éramos, em virtude de sua alta capacidade de negação pela performance, que muito raramente faz uso estrito da linguagem para comunicar: seu recado é diretivo e difuso, porque estético. 
Édipo fez perder a hegemonia porque a oferta de existências (im)possíveis pela TV e demais meios de massa ofereciam layouts de uma vida muito mais prazerosa. Bem ao estilo de vida Coca-Cola. Foi este supermercado de modelizações que a Internet alterou substancialmente com a difusão todos para todos. Auto-reflexividade que rompe com o cartel midiático que decidia como seriam as gerações. No campo micropolítico da Web, o agenciamento não-edipiano ganha possibilidade de atuação, pois os padrões de vida, de consumo dos pacotes prontos de subjetividade, estão todos a venda. Ao alcance de um único clique, de uma janela. A sociedade já não pode mais se defender dela mesma ${ }^{17}$.

O chat é um canal de exibição de personas, personalidades e estilos de vida diferentes nos quais todos vêm à tona. Imensa feira para consumo de avatares para a vida, de maneiras de viver. Mostro-me sem me verem, com liberdade para arriscar e adquirir novas formas efetivas de trocas afetivas, numa configuração social de compartilhamento das experimentações subjetivas. Saem de cena as figuras absolutizantes do pai e da mãe. Entram os grupos, os bandos, os contatos difusos e virtuais. Espelho-me em todos eles, naqueles que mais me aprazem. A fronteira para o reconhecimento e legitimação de uma autoridade ou de um modelo não guarda uma delimitação fixa. É aberta e de longo alcance, além de mutante e instável ${ }^{18}$. A identidade é fractal.

Segunda, 20 de outubro de 2001. 03h09. Interna, PVT.

Suba: Eu não saberia te descrever, Etrof

Etrof: francamente Suba, eu esperava mais de você.

Etrof: não sou só uma mente pensante

Etrof: dá pra entender que é disso que eu falo?

Etrof: sou humano

Suba: Explique.

Etrof: Eu não tenho só idéias. Tenho sentimentos.

Etrof: Tenho caráter.

Suba: Isso parece ótimo.

Etrof: Não apenas opiniões

Suba: Mas acho que o que você está querendo dizer é "tenho afeto".

Etrof: Não.

Etrof: Tô querendo dizer tenho ódio, tenho egoísmo, tenho muitas coisas, mas você só analisa as minhas idéias. Como se eu fosse um computador.

Etrof: E você faz isso com todos.

Suba: Etrof, como posso avaliar gente invisível?

Etrof: fazendo como eu, ora bolas. Eu vivo aqui, conheço todo mundo.

Suba: O que posso ver por aqui são as idéias. E mesmo assim, de forma bem porca.

Suba: Explique melhor, Etrof.

Suba: Etrof, isso aqui é um meio de comunicação, não um meio de afeto. Esse é o problema. Ele não vai resolver nossa carência. Não mesmo.

Etrof: Adeus Suba

* Etrof saiu do canal \# BIC

Corte para:

Segunda, 20 de outubro de 2001. 03h49. Externa, \#BIC

Session Ident: Etrof

Suba: Etrof, o que você espera disso aqui? Diga, quero saber. :) 
Etrof: Quero saber como estão a Apple e o letrapet... estou preocupado com eles...

Suba: Você é do Rio, Etrof?

Etrof: Não, sou da Bahia

Suba: Etrof, você não vai encontrar esse pessoal, vê?

Suba: Moram longe demais. Vai, no máximo, ver uma vez ou outra. Não podem ser seus amigos

reais.

Suba: Mas podem ser seus amigos * na cabeça* :D

Etrof: Suba: eu os amo. Eu os admiro. Eu os respeito.

Suba: Sim Etrof, todos temos afinidades por aqui.

Etrof: Eles estão longe mas são melhores que a maioria das pessoas daqui.

Etrof: Vivo cercado de imbecis na minha cidade.

Suba: Ok, mas é preciso encarar os fatos. Como podem seus amigos serem de IRC, virtuais?

Etrof: Não estou preocupado. Meus amigos são eles porque eu decidi.

Session Close: Mon Oct 20 04:13:58 2001

A identidade é a dos habitantes da cidade grande, que flertam com o periférico ou porque dele descendem, ou porque vêem ali um ótimo agenciamento subjetivo. Eterno fluxo intermitente, este cidadão zapeador muitas vezes é (i)migrante, acostumado a perambular entre diferentes espaços em que acorda, almoça, trabalha e dorme, ao longo de um único dia.

O corpo é signo e currículo, material de identidade e identificação. Adereços que não enfeitam, mas servem ao propósito de comunicar quem se é, de onde se veio e para onde se está indo. Tatuagens, body piercings, roupa démodé e unisex, visual pós-tudo. Adotam-se padrões de vida como padrões de consumo, numa curiosa e embaralhante confusão entre ser e aparentar. Diante do rigor de crença da modernidade, da lealdade e honestidade frente aos ideais e diretrizes morais, emerge a opção estética nem sempre vinculada à conduta ética: vestidos com as anti-regras de um despojamento obrigatório. Os layouts são muitos: careca, cabelo ensebado com gel, topete, tênis, calça jeans, celular, mochila up to date, barba por fazer, costeleta sempre feita - o estilo é étnico, conforme a world music, a moda é street, conforme a passarela, e a ideologia é a das minorias, porquanto que mediadas. Orientação é um termo quebrado, riscado e ferido de morte.

Essa subjetividade fragmentada não é necessariamente inventiva, ainda que adquira incessantemente novas formas a serem consumidas como pacotes ready-made. E são muitos os pacotes de personalidade, fabricados no frenético ritmo tecnológico. Mudam rapidamente, variando segundo a nova tendência, o novo must a que se deve entregar-se. Por ser pautado pela lógica dos trends e não da experiência, as contradições são de todo curiosas. Às vezes o indivíduo aceita determinado discurso porque uma coletividade o fez universal, e tal estilo de vida ou programa de consumo deve ser então seguido, penetrando por toda a couraça reificada do status quo. Embora real, durará apenas o intervalo de um novo input, mecanismo que o descartará imediatamente. No íntimo destes usuários, entretanto, permanecem as mesmas crenças velhas e preguiçosas. A adoção de padrões é efêmera e inexiste qualquer comprometimento: as crenças devem ser outorgadas e aceitas apenas em sua superfície ${ }^{19}$. 
Terça-feira, 14 de outubro de 2001.05h38 AM. Externa, \# Filosofia

Danyz: E o que seriam essas crenças velhas, conservadoras e pequenas?

Danyz: Conservar o quê? E velha desde quando?

opertone: Acho que você está apto para responder essas perguntas. Ou não?

Danyz: opertone: suponho que não, pois tento me lembrar quando começou o tal preconceito aos homossexuais. Desde sempre a sociedade não gosta dos homossexuais, e tenho o direito de querer que meu filho não veja isso.

Mertiolato: o homossexualismo existe desde a época das cavernas.

Danyz: acabei de me lembrar que até mesmo em Atenas existia um código secreto com os pés pra um homossexual chamar o outro pra sua casa.

opertone: Qual sua dúvida então, Danyz?

Danyz: Seria, então, pra conservar as crenças velhas e conservadoras da antiguidade?

opertone: Danyz. Você entendeu o que eu escrevi?

Danyz: opertone: sim... só estou tentando entender de onde vieram tais crenças.

opertone: Não faço referência a esta ou aquela crença, atualmente ou [sic] "no tempo das

cavernas". Faço referência à habilidade existente de um mamute declarar "não tenho preconceito contra homossexuais" ao mesmo passo em que diz "jamais meus filhos poderão ver em um casal homossexual, algo que mereça ser chamado de família". Compreende?

opertone: Essas crenças não são particularmente interessantes. Elas quase seguem um padrão, 0 da atualidade. O que é interessante são os contorcionismos que são feitos para conviver com elas.

São publicitários, jornalistas, fotógrafos, designers. Trabalham com imagens em um mundo de demanda infinita deste material. Upgrade do cabelo para um photoshop do visual ${ }^{20}$. Já vêm de famílias com pais separados, de forma que o casamento é desidealizado. Importa antes a independência financeira, o grupo de amigos, e ter filhos não é nenhuma prioridade. Família? O que há são grupos formados por afinidades eletivas em torno de questões de identidade ou identificação.

A música é eletrônica, do trance ao rap, nos conformes com a Era Tecnológica. Festivais turbinados por anfetaminas super processadas. O ambiente é lounge, o sentimento, amor, e a ordem, transcendente. A conversa é simbólica e não gramatical; a poesia é visual. São estas experiências compartilhadas que legitimam os sujeitos em condição de criadores de linguagem - desde as gírias e neologismos que se produzem a partir das turmas de adolescentes e jovens, procurando nomear vivências singulares $e$ inscrevê-las no campo do Outro, até a produção de novas narrativas que forneçam sentidos para experiências que a cultura ainda não classificou ${ }^{21}$. Objetivos e sentidos gravitam em torno dos objetos; na obrigatoriedade implícita do consumo. Sociedade e sistema dos objetos, dos hobbies e dos clubs para dançar, que não são simples espaços, mas locais para ver, para se ver e para ser visto.

A referência cultural ignora a política institucional e os imperativos ideológicos. Em um sentido inteiramente oposto, a referência máxima é a industria, num curioso arcabouço de citações e fragmentos de comerciais, produtos e gadgets diversos. Cultura das mídias, agenciada por informações desconexas ${ }^{22}$. A produção dessa subjetividade se faz com uma miríade de signos sem referência concreta a um lugar ou a um conjunto fechado de informações e opiniões. A liberdade se quer total, e por isso mesmo, ineficaz ${ }^{23}$. Quando se viu, Édipo era uma lenda, e a lenda sumiu. Só há máquinas e máquinas que operam máquinas. 
Não falamos apenas de adolescentes e jovens inseridos na cultura de consumo capitalista. O que ocorre é o componente do bando, da fratria, encontrando uma canalização possível no instante em que as redes telemáticas possibilitam esses tipos de agrupamentos. Mas o bando sempre existiu e sempre existirá, estando mais ou menos presente na dinâmica social, pois além de espaço necessário de passagem, é também lugar de contestação e de legitimação de experiências de liberdade.

Essa experiência é feita testando e desvirtuando o poder da autoridade paterna, criando orfandades simbólicas entre seus membros ao mesmo passo que lhes ampara. Espécie de coadunação que deseja se desvirtuar, ser produzida por uma ordem extrafamiliar, fora do ditame edipiano. O sentido do grupo é ser efêmero, pois a própria agregação implica na dispersão. Sua finalidade última é a identificação transitória entre os membros, ampliando os campos de experiência ${ }^{24}$.

\section{ESQUIZO}

Na busca pelos locais em que novos agenciamentos subjetivos são praticados, constata-se que estes lugares guardam um estranho truncamento entre espaço e tempo. Trata-se de uma encruzilhada onde o entrar e sair da modernidade se repete randomicamente. Do ponto de vista teórico, podem ser subsumidos no debate entre desterritorialização e (re)territorialização, que atravessa diversas disciplinas, diversas questões. Comum a elas todas, está o questionamento da relação fixa para com o território geográfico, o local, apontando para o que parece ser uma constante mudança nos locais de estabelecimento dos laços sociais. Assim, temos nos espaços geográficos uma mobilidade desconfortável, da mesma forma que a cultura não é mais entendida como uma relação naturalizada entre territórios geográficos e sociais. Entrementes, as relocalizações no território passam a receber uma atenção mais cuidadosa referente às suas brechas, suas aberturas imperceptíveis a velhas e novas produções simbólicas. O próprio uso recorrente dos conceitos de territorialização e desterritorialização reflete a proeminência de uma discussão que tenta, de maneira algo canhestra, apontar e delimitar os espaços e lugares onde o fenômeno ocorre.

Acreditamos que o modo de operar da contemporaneidade é fundamentalmente de desterritorialização. Muitas vezes incondicional, a pulverização dos corpos de unidade etológica faz nascer uma cosmogonia do micro, do inominável, do sem tradição. O universo da subjetividade contemporânea é uma reunião entre pares intercambiantes em tendas temporárias: nomadismo generalizado. 
Nesta tomada de cena não temos um Eu central e consolidado, invencível. Nem tampouco uma infinidade de personalidades antagônicas presas na gaiola chamada Sujeito. Comportam-se antes como uma rede de estados intensivos, operando cortes e extrações não ordenadas no tecido social. Operam a realidade pela imaterialidade. Estados que se sucedem e se transpõem compondo práticas singulares, muitas vezes disjuntivas, outras vezes de saborosa cooptação de aliados. Essa promiscuidade amoral entre os agentes reflete a diretriz máxima de que para o desejo não importa o que isso quer dizer, mas sim como isto funciona. Sai de cena o ato, a ata e a reunião, entram as conexões, as conjunções e as disjunções.

O fluir esquizo é essencialmente contrário às formações controladoras, atuando por destruição das formas cansadas de expressividade normativa. Há um bombear oxigenador no campo social. O passeio mudo do esquizo procura colocar o foco nos deslocamentos do desejo, nas viagens imóveis daquilo de Deleuze chama de Corpo sem Órgãos. O estruturalismo quer o discurso e a análise. A análise do esquizo quer a intensidade, a hecceidade do movimento. São faixas, trilhas, devires e limiares de intensidade que podem configurar uma prática, um agenciamento, e não o dessecamento frio e distante da gramática subtraída.

Dessa forma, não se pode ler estes $\log s$, estes relatos, como tentativa de representação. Não se trata de representação, pois não se trata de acreditar ou não que se é isso ou aquilo outro. Trata-se de representarse na diferença, ser atropelado por formas que não existiam. Não são exatamente formas, são intensidades, velocidades, temperaturas, distâncias e variáveis indecomponíveis. Formigamento e inflamação, puro enlamear.

A semelhança, categoria de exeqüibilidade obrigatória para o congelamento estruturante, descansa no desuso. A busca por semelhança e imitação é parelha a um real de repetição e determinação. A curva aqui é outra, é a da indeterminação e da incerteza que descarta um entendimento higiênico do todo. São antes zonas de intensidade e de vizinhança em buracos, spots de multiplicidade.

Daí a importância dos bandos, dos grupos, da matilha. O estamento é líquido, o que não quer dizer que não exista: sua prática pouco igualitária e ultra-hierárquica é uma linha de fuga, libertária ou opressiva mas ainda uma linha que desterritorializa. Porque cada um efetua uma ação individual, ao mesmo tempo em que é parte do grupo. A estratégia é a da periferia, comer pelas bordas e não pelo centro. Vai-se ao centro para então se voltar às bordas, mantendo-se ligado por uma espiral em movimento. Entra nick sai nick, o bando permanece. Apesar de todo investimento do grupo para sua unidade, sua concretude perfeita e acabada, o agrupamento virtual é contrário ao estar fundido, aos esquemas de jogo pelo centro. 


\section{SEXUALIDADE MÁQUINA}

Não é a tríade familiar que coordena o bando. É a experimentação dos irmãos, campo fértil para especulações e brincadeiras sexuais, traçando outras linhas no circuito libidinal. Não é apenas um deslocamento usual da experiência incestuosa com as figuras fraternas, mas investigação e pesquisa sobre o campo do desejo. Acoplamentos que formam uma rede, diferente da unidade excludente da ordem fálica.

As novas formas de relação nos bandos seguem o horizonte da feminilidade como modalidade primordial na subjetivação. Isso porque a feminilidade se constitui sob um erotismo que positiva a fraqueza, $o$ desamparo e a cooperação. Édipo, motorizado pelo fálico onipresente, é o retrato enquadrado da autosuficiência moderna, valor máximo que operacionaliza a disputa entre o que vai mandar e o que vai obedecer, sendo seu oposto, a feminilidade, o reconhecimento da precariedade e da fragilidade imanentes às formações do sujeito ${ }^{25}$. Feminilidade porque potencializa a capacidade de gerenciar e de cooperar, habilidade cirúrgica na troca intersubjetiva. É, assim, o reconhecimento derradeiro de que o sujeito não é onipotente, não se basta a si mesmo e ao mundo, mas pelo contrário, é um animal, é um mamífero sexuado. Sua matéria-prima é a incompletude, e sua busca pelo afeto não é só óleo para a engrenagem do corpo, mas vitalidade que procura não só o que não se é, mas o que jamais se poderia ser. Feminino como força de resistência, que se abre ao outro com delicadeza, sem estratégia. É esta uma ordem que espera não a separação entre masculino e feminino, mas a circularidade entre os vetores sexuais, pois a precariedade de todos emerge como princípio $^{26}$.

Domingo, 17 de janeiro de 1999. o0h22 AM. Externa, \# Illuminati

Tópico: 'Casamento polígamo: "Você, Róbson, aceita Stephanie, que aceita Andréa, que aceita Verônica, que aceita Róbson, como seu legítimo bolo de carne?" ,

Sandy: Vamos...

Tonica: Vamos trepar

*** Sandy é agora MeninaPrestativa

Votovia: Tonic, já vai assim entrando logo? Tem que ir devagar.

MeninaPrestativa: Você não viu nada, fiquei excitando um molequinho de 14 anos no Brasirc. ;-)

MeninaPrestativa: Porra, meu pai entrou aqui, merda merda. :-)

Ghino: hahahahahaha

Asterix: hehehhahaha

Tonica: Ele viu alguma coisa, Menina?

MeninaPrestativa: Não, ele não viu nada.:-)

Votovia: Ele sentiu um cheirinho no ar? :)

Tonica: tal qual um cão farejador:)

Corte para:

LucaCamparini: É... com certeza vocês confundiram a coisa. Entrei aqui porque queria discutir esses temas, e não cair num bunda lê-lê. Aconselho vocês a procurarem por sexo, pois seus hormônios estão brigando com seus neurônios, e estão vencendo. 
Deleuze lembra, no entanto, que as próprias vivas à vida são freqüentemente entoadas pelas mais frias e ressecadas mulheres, apartadas de todo seu corpo e de suas máquinas de desejar. Quer com isso deixar claro que não basta a idealização do feminino como padrão conjuntivo da subjetividade. A coluna do meio, da bissexualidade gerativa, corriqueiramente apontada como a sexualidade que contém em si as demais, todas desenvolvidas, é fundamentalmente resultado da mesma polarização dos tipos. O esquizo quer romper com os dualismos confortáveis, quer traçar linhas através deles. Pois assim como desejo não é apenas vontade, bissexualidade não é um conceito melhor que o da separação dos sexos ${ }^{27}$.

PhilipSS: Não gosto de homens. Tipo, mal consigo chegar perto, e beijar para mim seria hediondo. Não consigo ser homossexual, acho que sou reprimido.

Inclusa: Entendo... você é filho único?

PhilipSS: sim.

Inclusa: Hehe, bingo!

PhilipSS: E sem a figura paterna por perto, o que me faria viado direto e tal. Mas não, eu me libertei da minha mãe, ela não tem mais poder sobre mim. Estou tentando virar bi e vou vencer.

Corte para:

PhilipSS: É, eu tenho repressão homossexual também. Queria ser veado, mas não consigo.

Fynes: Ah é? Eu não quero. Nem se quisesse, conseguiria.

PhilipSS: Eu pretendo, tenho trabalhado para isto.

Fynes: Não se esforce muito.

Corte para:

Mimms: Tsc, acho que você não vai fazer sucesso enquanto não virar gay.

Louva-deus: pois estou a um passo de fazê-lo. Estou na zorra com as mulheres.

Deleuze pensa é numa transsexualidade do micro, fazendo com que a mulher contenha em si tantos homens quanto o próprio masculino; e o homem, todo o universo de mulheres que define o feminino. Ele pensa em interpenetrações, na capacidade de subverter a ordem dos vetores sexuais, de entrar uns com os outros, nas relações de produção de desejo que subvertem a ordem estatística dos sexos. Fazer amor não é só fazer um, nem mesmo dois, mas fazer cem mil. É isso; as máquinas desejantes ou o sexo não humano: nem um nem dois sexos, mas n... sexos. A esquizo-análise é a análise vairiável dos n... sexos num sujeito, além da representação antropomórfica que a sociedade lhe impõe e que ele se dá de sua própria sexualidade. A fórmula esquizo-analítica da revolução desejante será primeiramente: a cada um seus $\operatorname{sexos}^{28}$.

Para o autor seria preciso algo que, sendo comum aos dois sexos, pudesse faltar a um e ao outro, não sendo nunca suficiente. Deleuze pensa numa distribuição da falta em duas séries não simétricas que fizessem uso das disjunções: o "você é menina ou menino" - polarização edipiana por excelência - que deveria sobre ela fazer valer a capacidade de resignar a exclusividade do fálico ${ }^{29}$. É a ruptura com os princípios dados: ser uma coisa e ao mesmo tempo outra. Uma menina que simula um lobo que imita um velho. Simulação e devir, o desejo rompe porque ultrapassa, passa através. 
Os autores abordam as modalidades sexuais não porque sejam imanentemente revolucionárias ou conservadoras, coisa que de fato não são. Mas porque procuram demonstrar como existem certos formas do amor que são caracterizados por uma sobrecarga mortífera de Édipo. São investimentos pela libido de um campo social histórico ou geográfico, do qual os seres amados e desejados recebem suas determinações. Édipo é uma dessas formas, índice de investimento reacionário. E as figuras bem definidas, os papéis bem identificados, as pessoas bem distintas, resumindo, as imagens-modelos, mãe, noiva, amante, esposa, santa e puta, princesa e empregada, mulher rica e mulher pobre são dependências de Édipo, até nas suas inversões e, substituições. Tais imagens, seus campos de existência, suas funções e recortes são imediatamente demandas de um código, uma axiomática social em que é a libido quem possibilita sua continuidade, sua vitalidade. Para os autores, essas formações subjetivas funcionam como simulações de um conjunto social em que os extratos trabalham para reinvestir nele mesmo seu próprio código. Por isso amores conservadores, pois reinvestem no próprio campo, mantendo-o. Já os assim chamados 'amores revolucionários', trabalham para introduzir índices nãofigurativos, onde se canalizam os fluxos não-modelizados do desejo, as linhas, os devires: instantes de singularidade ${ }^{30}$.

Essa é uma possibilidade que os chats também cumprem, sendo inevitável que na virtualidade tal confusão se generalize. O jogo de personificação de gêneros, sexos e personagens fictícios, é recorrente. O caso mais extremo e comentado é o de Donna Haraway, autora do Manifesto Cyborg ${ }^{31}$, para quem a androginia é uma necessidade à superação da dualidade masculino/feminino. Tal polaridade redutora de gêneros encontraria seu termo por meio de uma constituição ciborgue. O corpo, já virtualizado, vislumbra a possibilidade de relações no outro sexo, no misto de confiança e risco próprios à relação carnal. Sintomaticamente, a moda já havia imposto o standard de uma androginia disjuntiva e funcional. E não é com pouco assombro que se pode imaginar que modificações plásticas, anatômicas e hormonais a ciência não poderá promover através da incessante investigação genômica. A indústria da aparência não se descola das pesquisas biotecnológicas. Esses complexos de biotecnologia, engenharia genética e medicina podem alterar um corpo que, simbolicamente, já está há muito sendo operado além dos bisturis. Usam-se serrotes, rebites e silício ${ }^{32}$. 


\section{NOTAS}

${ }^{1}$ Ocorre que nesses jogos, grupos ou comunidades, o outro já não é um aglomerado abstrato, um campo de inferências públicas tal como a sociologia usualmente entendia a tessitura do social. O próprio outro é, em sua concretude, mais um indivíduo auto-referenciado.

2 "No imaginário cultural havia uma sintonia quase perfeita entre o modo concreto de subjetivação dos indivíduos e a ação física e simbólica do nome do pai. Deus, professor, governante, sacerdotes, chefes militares, médicos, artistas, cientistas, psiquiatras, psicanalistas - todos pareciam encarnar os signos da potência paterna masculina. A função paterna podia ser, então, abstraída e postulada como tipo lógico do qual derivavam as diversas instanciações empíricas. Cada pai real ou seu substituto ilustrava a ocorrência particular de um caso ou função geral - a função paterna”. Maria Rita Kehl (org). Função Fraterna. Rio de Janeiro: Relume Dumará, 2000. (p.11).

${ }^{3}$ Para Deleuze e Guattari, embora reconheçam a trajetória de explosão do patriarcalismo pelo capitalismo industrial, este ainda oferece Édipo e apenas Édipo: “a sociedade dos irmãos é muito morna, instável e perigosa, ela deve preparar o reencontro de uma equivalente autoridade parental, deve fazer-nos passar ao outro pólo. Conforme sugestão de Freud, a sociedade americana, a sociedade industrial com anonimato da gestão e desaparecimento do poder pessoal, etc., nos é apresentada como um ressurgimento da 'sociedade sem pais'. Está claro portanto, que só se deixa um pólo de Édipo para passar ao outro. Não há como sair, neurose ou normalidade. A sociedade dos irmãos não encontra nada da produção ou das máquinas desejantes; ela estende, ao contrário, o véu da latência.” Deleuze, Gilles. Guattari, Félix. O Anti-Édipo. Capitalismo e Esquizofrenia. Rio de Janeiro: Imago, 1976. (p.108).

4 "Crianças e adultos, até então psicologicamente dependentes da instituição familiar patriarcal, foram postos sob a tutela das burocracias anônimas de cuidados médicos, psicológicos, sociais, educativos ou da propaganda maciça de bens de consumo com obsolescência programada. A sociedade industrial e capitalista dispensou a mediação do pai e passou a gerenciar, de forma direta, o sujeito e seus desejos, de modo a adequá-los às suas finalidades econômicas e políticas. A ordem piramidal, com o pai no topo, deu lugar à proliferação de instâncias de controle e incentivo à produção de novas subjetividades. Desde então, seguiu-se o coro de vozes contra a 'decadência da função paterna', cujos últimos ecos se encontram nas idéias da 'personalidade' e 'cultura' narcísicas dos anos 70-80”. Maria Rita Kehl (org). Função Fraterna. Rio de Janeiro: Relume Dumará, 2000. (p.12). Sobre Kafka e a questão da autoridade, discutida no âmbito do Estado moderno, ver: Löwy, Michael. Redenção e Utopia. São Paulo: Cia das Letras, 1989.

5 "Uma cultura expressa os seus conflitos essenciais nas suas psicopatologias dominantes. A histeria, com origem na repressão sexual, foi a neurose da época de Freud. Um pensamento reprimido encontra expressão num sintoma físico: um membro paralisado fala de um desejo inaceitável. Em fins do século XX, os casos de histeria desapareceram praticamente. Na realidade, os médicos declaram que os seus doentes raramente sofrem de um sintoma claro de qualquer gênero. Do que eles sofrem é dessa sensação de vazio, de não sentir nada, de não serem capazes de se relacionar. O processo esquizóide substituiu as neuroses clássicas" Na Nota Bibliográfica n ${ }^{\circ}$ 21, Turkle complementa: "Alan Wheelis faz a seguinte observação acerca das alterações dos sintomas psiquiátricos: 'Muitos elementos da motivação que eram geralmente reprimidos no século XX são-no agora raramente. As provas relativas à agressão são equívocas, mas não subsistem dúvidas quanto à libertação da sexualidade. A menor incidência de histeria está de acordo com estas observações e é um fato. A histeria depende da repressão e está a tomar-se rara; as perturbações de caráter refletem deformações no funcionamento do ego e estão a tornar-se vulgares. À medida que desaparecem as neuroses com sintomas nítidos, tomam-se preponderantes estados vagos de falta de objetivos e de inutilidade." Turkle, Sherry. O Segundo Eu - Os computadores e o espírito humano. Lisboa: Presença, 1989. (p.117).

${ }^{6} \mathrm{O}$ entendimento dado à dita "compreensão sensorial" feita pelos participantes dos produtos culturais é uma operação que trata de estabelecer, por meio de rápidas distinções sobre nuances, reconhecimento e valoração nos objetos, e é em muito próximo à clássica definição de Montesquieu sobre o gosto: "gosto é a vantagem de descobrir com sutileza e presteza a medida do prazer que cada coisa deve dar aos homens". No original da obra inacabada e inicialmente pensada para a Encyclopédie de Diderot: "Le goût n'est autre chose que l'avantage de découvrir avec finesse et avec promptitude la mesure du plaisir que chaque chose doit donner aux hommes." Montesquieu, Charles-Louis de Secondat. Essai sur lê goût. Paris: Rivage Poche, 1993. Teixeira Coelho, comentando a assertiva de Montesquieu sobre o gosto, diz que se trata da capacidade de estabelecer distinções entre elementos sutis em um tempo exíguo, de maneira a perceber diferenças que não podem ser compreendidas reflexivamente, por meio do pensamento pausado e distanciado: "gosto, num sentido abrangente, é a faculdade de discernir características ou qualidades de objetos e fenômenos. Aquilo que, independente de ser bom ou mau, correto ou não, liga as pessoas a uma coisa pelo sentimento". Coelho Netto, José Teixeira. Dicionário Crítico de Política Cultural. São Paulo: Iluminuras, 2004. (p.188).

7 "Mas, pergunto, por que continuar cultivando essa imagem? Por que continuar descrevendo o pai, a palavra do pai ou o poder do pai como condição sine qua non da paz neurótica? Por que imaginar que onde não há pai de horda, pai morto, pai simbólico, pai imaginário, pai real, deve advir o caos, o gozo tranqüilo das montagens perversas, ou, o que é mais trágico, as psicoses? Quem é o pai do qual tanto falamos em psicanálise?” Maria Rita Kehl (org). Função Fraterna. Rio de Janeiro: Relume Dumará, 2000, (p.11).

8 "Muitas forças estão trabalhando - de forma invisível - para dissolver a família nuclear e resgatar o bando em nossa própria sociedade da Simulação pós-Espetacular. Rupturas na estrutura do trabalho refletem a "estabilidade" estilhaçada da unidadelar e da unidade-família. Hoje em dia, o "bando" de alguém inclui amigos, ex-esposos e amantes, pessoas conhecidas em diferentes empregos e encontros, grupos de afinidade, redes de pessoas com interesses específicos, listas de discussão etc. Cada vez mais fica evidente que a família nuclear se torna uma armadilha, um ralo cultural, uma secreta implosão neurótica de 
átomos rompidos. E a contra-estratégia óbvia emerge de forma espontânea na quase inconsciente redescoberta da possibilidade - mais arcaica e, no entanto, mais pós-industrial - do bando”. Bey, Hakim. TAZ: Zona Autônoma Temporária. São Paulo: Conrad, 2001. (p.24)

${ }^{9}$ Mas isso não implica que Édipo seja um determinismo biológico, como muitas vezes se fez crer. Ao contrário, é uma função de agenciamento, de desejo, e por isso uma construção social: “A principal preocupação (de Lévi-Strauss) é rebater a tese de que o complexo de Édipo está na origem das sociedades humanas, apresentando, contrariamente, a de que a base está no princípio de exogamia. Para Lévi-Strauss, a troca tem valor social e é fundamento comum de todas as instituições matrimoniais. Não se trata apenas de um intercâmbio; para que haja incesto é preciso também a ação conjunta da exogamia e é este o princípio da troca generalizada. Diferentemente da endogamia, naquele sistema os matrimônios devem ser realizados com membros de uma tribo estranha sob a pena de a própria tribo ficar condenada ao desaparecimento. Na roca que se realiza entre as tribos, a mulher funciona, segundo Lévi-Strauss, como moeda de troca. À endogamia junta-se a lei do incesto, que tem valor fundamental permanente e coextensivo a todos os grupos sociais. No incesto, para Lévi-Strauss, não se trata exatamente da proibição do casamento com a mãe ou com a irmã. O indivíduo é obrigado a ceder mãe ou a irmã a outra tribo. Ou seja, se há o desejo incestuoso, ele é posterior e não anterior à relação exogâmica. O desejo não é algo intrínseco à mãe, um princípio biológico, mas um fato eminentemente social. O casamento é visto como o encontro dramático entre natureza (marcada pela indivisão e apropriação) e a cultura. É arbitragem entre amor aos pais e amor conjugal.” Marcondes Filho, Ciro. A Produção Social da Loucura. São Paulo: Paulus, 2003. (p.159-160).

${ }^{10}$ Deleuze e Guattari rebatem: "Tudo se converte em neurose, ou tudo se derrama em psicose: no entanto, não é assim que a questão deve ser colocada. Seria inexato guardar para as neuroses uma interpretação edipiana, e reservar às psicoses uma explicação extra-edipiana. Não há dois grupos, não há diferença de natureza entre neuroses e psicoses. Porque de qualquer maneira é a produção desejante que é a causa, causa última, seja das subversões psicóticas que quebram Édipo ou o submergem, seja das ressonâncias neuróticas que o constituem." Deleuze, Gilles. Guattari, Félix. O Anti-Édipo. Capitalismo e Esquizofrenia. Rio de Janeiro: Imago, 1976. (p.164).

11 "É por isso que falamos apenas de um pólo esquizóide no investimento libidinal do campo social, para evitar tanto quanto possível a confusão do processo esquizofrênico com a produção de um esquizofrênico. O processo esquizofrênico (pólo esquizóide) é revolucionário, no mesmo sentido em que o procedimento paranóico é reacionário e fascista; e, desembaraçadas de todo familialismo, não são essas categorias psiquiátricas que devem nos fazer compreender as determinações econômicopolíticas, mas exatamente o contrário.” Deleuze, Gilles. Guattari, Félix. O Anti-Édipo. Capitalismo e Esquizofrenia. Rio de Janeiro: Imago, 1976. (p.482).

12 “A função dos laços e das identificações horizontais enriquece e complementa a função estruturante da relação vertical (com o pai, a autoridade, a tradição etc.), mas não a substitui. Segundo: esta noção não vale só para se pensar a subjetividade contemporânea, embora faça mais sentido e provavelmente seja mais importante nas sociedades modernas, onde o sujeito, órfão de uma estrutura tradicional forte, sente-se responsável, como que sozinho, diante do seu próprio destino. O esquecimento de nossa dependência em relação, não somente ao Outro, mas aos outros, é uma das grandes causas de sofrimento psíquico, angústia e desamparo nas sociedades atuais”. Kehl, Maria Rita. Tensão Fraterna. Entrevista a Revista Insight. Revista Insight, Estruturas Socioculturais, Ano XI, N 115. 03/2001. (pág. 6, $1^{\circ}$ parágrafo).

13 "Esta passagem do coletivo ao individual através da narrativa mítica faz muito sentido na modernidade, quando vivemos sob formas muito cristalizadas do mito. O individualismo moderno promove o recalque do caráter coletivo do que determina nossos atos - isto é justamente o que precisa ser recuperado para restaurar a confiança dos sujeitos no laço social, em relação ao qual somos todos ao mesmo tempo, agentes e objetos." Maria Rita Kehl (org). Função Fraterna. Rio de Janeiro: Relume Dumará, 2000, (p.34).

${ }^{14}$ As semelhanças entre um paciente de Transtorno de Déficit de Atenção e Hiperatividade (TDA/H) e um indivíduo qualquer afetado pelas características da vida pós-moderna são muitas. Rossano Lima relaciona os sintomas desta doença com as características do sujeito pós-moderno, cujos novos diagnósticos comporiam mais um comportamento coletivo da vida fragmentada que o sintoma de uma epidemia alarmante. Perguntado pela repórter Carla Rodrigues se vivemos em uma sociedade em estado de TDA/H, ele diz: "Podemos dizer que a rápida propagação do TDA/H depende de um amplo arranjo cultural a lhe respaldar e ressoar. Edward Hallowell, um dos principais divulgadores do transtorno nos EUA, chegou a propor que a sociedade atual é indutora de 'pseudo-TDA/H'. Não é por acaso que o surgimento e a explosão desse diagnóstico se dá agora, e não há trinta ou sessenta anos. Tais afinidades não permitem que se conclua definitivamente por uma 'etiologia cultural' do transtorno, mas nos autorizam a conjecturar que algumas características da vida e da subjetividade contemporâneas, resultantes da cultura da fragmentação e da provisoriedade, fortalecem a identificação das pessoas com as descrições do transtorno". E continua: "Num mundo no qual os referenciais tradicionais dos quais as pessoas extraiam as matérias-primas de sua identidade, como a Igreja, as ideologias, o trabalho e a família, têm perdido potência e se desagregado, o corpo tem se tornado uma das únicas fontes de certeza e estabilidade. Essa ascensão dos atributos corporais a matrizes identitárias privilegiadas reforça a decadência da interioridade como a depositária das verdades do eu. Assim, ao invés de procurar saber o que se é por meio de um demorado e complexo labor interior, perscrutando sentimentos e representações conflituosas, tem se preferido recorrer à biologia para explicar idiossincrasias e comportamentos. Atribuir suas dificuldades ou as de seus filhos ao TDA/H é um exemplo desse tipo de recurso." Somos todos hiperativos, por Carla Rodrigues, $24 / 05 / 2004$. Disponível em: http://nominimo.ibest.com.br/

${ }^{15}$ Ver a respeito Kaminski, Omar. Internet Legal: O Direito na Tecnologia da Informação. Londrina: Juruá Editora, 2003.

${ }^{16}$ Ver a respeito Goffman, E. A Representação do Eu na Vida Cotidiana. Vozes: Petrópolis, 1996.

17 "O afeto participa da fraternidade como participa de toda forma de vínculo humano, mas a fraternidade se define antes por um campo identificatório. Eu posso me sentir 'mana' de pessoas que eu nem conheço, identificada com os discursos que 
eles/elas produzem. Posso me sentir pertencendo a várias fratrias, algumas de convivência direta - pessoas com quem produzo algum trabalho, ou grupos de amigos fiéis -, outras de pertinência simbólica, movimentos musicais, políticos, correntes de pensamento dentro da psicanálise, etc.”. Kehl, Maria Rita. Tensão Fraterna. Entrevista à Revista Insight. Revista Insight, Estruturas Socioculturais, Ano XI, N 115. 03/2001. (pág. 8, $3^{\circ}$ parágrafo).

${ }_{18}$ Aberta, de longo alcance e mutável. Quando se fez presente no Iraque pós-guerra, os primeiros cybercafés registraram palavras maravilhadas como, por exemplo, "aquilo foi mágico" e "descobrimos as realidades do mundo exterior, a vida verdadeira". O país, assolado pela violência e pela miséria da guerra, registra que ao primeiro vacilar a janela do mundo se abre pela via tecnológica. Não há como escapar, acima ou abaixo d'água. A sociedade tecnológica da informação é inevitável, e sua dominação, implacável. Sobre a instalação dos cybercafés no Iraque após a tomada americana, ver Le Monde. Iraquianos descobrem as emoções do "Chat", os sites eróticos e a "verdadeira vida". Por Rémy Ourdan, 18/10/2003. Disponível em http://www.lemonde.fr/

${ }^{19}$ É importante vasculhar com cuidado a profusão dessas criaturas culturais efêmeras. É certo que o corpo social não cansa de oferecer inúmeros pacotes de subjetividade, padrões de vida e de consumo prontos para consumo, numa repetição incessante e cansativa. É fundamental, entretanto, entender o consumo destes protocolos de vida não como decorrência cultural menor, insignificante, mas como elemento integrante na explosão de processos, como mola de ativação cultural. Isso porque o consumo não é em nenhuma hipótese uma esfera apartada da dimensão cultural. Pelo contrário, as identificações engendradas pela maquinaria do consumo elucidam as dimensões do indivíduo na Era Tecnológica, cujo rastreamento pode ser feito por aquilo que é consumido (ou vetado ao consumo) dentro dessa dinâmica de permanente reciclagem nômade. Essas identidades tencionadas, fluídas e multipolares, são aliás dificilmente afeitas às amarras do conceito mesmo de identidade. Teixeira Coelho, entretanto, entende que o conceito de identidade ainda pode aplacar estas duas dimensões, tanto em sua constituição sólida e territorial quanto essas outras mais flexíveis, instáveis. Isso seria feito por meio da distinção entre Identidade e Identificação: "O conceito de identidade cultural aponta para um sistema de representação das relações entre indivíduos e os grupos e entre eles e seu território de reprodução e produção, seu meio, seu espaço e seu tempo. Este conceito de identidade vem sendo substituído, atualmente, pelo de identificação: mais do que um sistema, armado por unidades significantes estáveis a que correspondem unidades de significado perenes, o que se teria hoje seria um processo de unidades cambiantes, como significantes e significados, no qual os indivíduos e grupos entram e do qual saem intermitentemente, ao sabor de motivações de diversificada origem." Coelho N., José T. Dicionário crítico de política cultural. São Paulo: Iluminuras, 2004. (p.201-202).

20 “A respeito da transformação eletrônica das metrópoles, há algo pior do que o ser-explorado, que seria o não-ser-observado. O bem mais caro nas discussões sociais é, há muito, 'atenção pública' e não liberdade política, igualdade social, participação nos bens materiais e prosperidade geral. A 'atenção pública', porém, quando se tem, só é alcançável nos media. A sociedade e suas instituições não teriam mais nenhuma possibilidade de realizar suas promessas de que cada ser humano teria, em princípio, uma significação inestimável, a não ser pelos processos de simulação. A pessoa ou deveria participar em esforços nesse sentido de auto-encenação ou suportar sobre si amplas estratégias da publicidade organizadas. Pelo fato de tal derivação tardia da fama conceder a última garantia do próprio valor, os media seriam fatores indispensáveis da grande compensação social, na medida em que eles, pelo menos com o tempo, atribuiriam significado que em mais nenhum outro lugar - nem por parte da família, nem através da escola, nem no trabalho, etc. - pode ser obtido. Recentemente apareceu na imprensa sensacionalista uma mensagem de vitória desse tipo: uma enquête surpresa constatou que a profissão intencionada prioritária entre as jovens alemãs é a de modelo e entre os jovens é a de artista, quer dizer, designer. Uma acomodação super-rápida às exigências sociais: uns desejam tornar-se imagem, outros querem fazer imagens, ambos para capturar uma única significação que ainda conta: atenção pública." Kamper, Dietmar. Imanência dos media e corporeidade transcendental. Oito postos de observação para um futuro medial. Tradução de Ciro Marcondes Filho. Versão eletrônica disponibilizada em: http://www.eca.usp.br/nucleos/filocom/traducao8.html

${ }^{21}$ Kehl, Maria Rita (org). Função Fraterna. Rio de Janeiro: Relume Dumará, 2000

22 "Como referência máxima, a indústria. O estudo das marcas se estabelecerá como uma forma de eruditismo. Os comerciais (ou 'filmes'), como um instrumento na decodificação do mundo. Terá no século XX o seu marco zero. Falará em termos de décadas e não de séculos. Da psicanálise dissolvida em psicologia restarão tão somente os arquétipos; adotá-los-á, como guias. Emprestará glamour a produtos de baixa extração, convertendo em fashion até as havaianas mais legítimas. Desconfiará da medicina tradicional, preferindo sempre a alternativa. Procurará viver coisas verdadeiras, e não essa falsa rotina. Como supremo objetivo, aprender mais e mais sobre o mundo; aprender a aprender. O melhor trabalho ainda está por vir; e a melhor viagem, também. Não fará coleção de coisa alguma, agarrar-se-á com unhas e dentes à transitoriedade do dia-a-dia. Conceito é tudo, e a forma vem sempre antes do conteúdo. Sem optar por religião alguma, nutrirá uma admiração perene por figuras como Buda e Jesus Cristo; ícones para adornar o altar de uma vida vazia. Considerar-se-á uma pessoa única". Borges, Julio Daio. Retrato do jovem quando artista no século XXI. Digestivo Cultural \& Revista Nova-e. Disponível em: http://www.digestivocultural.com/colunistas/coluna.asp?codigo=665 e http://www.novae.inf.br/ativismo/unicos.html

23 "Além disso, a fratria estabelece laços de cumplicidade: a cumplicidade entre os irmãos permite, em muitos casos, enganar $o$ pai. Os irmãos conspirados autorizam-se a experimentar o que o pai, ou outra figura de autoridade, proíbe. Estes atos transgressivos não devem ser confundidos com a perversão, nem, com o apelo à intervenção paterna típica das 'delinqüências por sentimento de culpa'. Antes, devem ser interpretadas como moções de liberdade legitimadas pelo grupo, que possibilitam o enfraquecimento do poder de verdade absoluta que a palavra paterna tem na infância.” Maria Rita Kehl (org). Função Fraterna. Rio de Janeiro: Relume Dumará, 2000, (p.41).

24 "É na circulação horizontal que se cria a possibilidade, para os sujeitos, de desenvolvimento de trações identificatórios secundários (em relação ao traço unitário que dá consistência subjetiva ao eu), essenciais para permitir a diversificação das 
escolhas de destino, em relação às quais o traço unitário é insuficiente." Maria Rita Kehl (org). Função Fraterna. Rio de Janeiro: Relume Dumará, 2000, (p.43).

25 "Entretanto, enunciar que a auto-suficiência é uma formação ilusória não quer dizer absolutamente que aquela se volatilize enquanto formação, perdendo então a sua consistência. Pelo contrário, trata-se de uma formação poderosa que se encontra permanentemente presente no imaginário, contra a qual é necessário a realização de um trabalho constante e insistente do sujeito para denunciar firmemente o que há de gasoso e vazio nessa pretensão. A fraternidade seria a resultante final deste trabalho, já que mediante este seria a condição de precariedade do sujeito que se evidenciaria e sua demanda inequívoca do outro." Birman, Joel. Insuficientes, um espaço a mais para sermos irmãos! IN: Kehl, Maria Rita (org). Função Fraterna. Rio de Janeiro: Relume Dumará, 2000. (p.185).

${ }^{26}$ Ver a esse respeito: Birman, Joel. Cartografias do Feminino. São Paulo: Ed. 34, 1999.

27 "Miniaturizar, interiorizar a máquina binária, é tão deplorável quanto exasperá-la, não é assim que se sai disso. É preciso, portanto, conceber uma política feminina molecular, que insinua-se nos afrontamentos molares e passar por baixo, ou através". Deleuze, Gilles. Guattari, Félix. Mil Platôs - Capitalismo e Esquizofrenia. Vol. 4. São Paulo: Ed. 34, 2000. (p.68).

${ }^{28}$ Deleuze, Gilles. Guattari, Félix. O Anti-Édipo. Capitalismo e Esquizofrenia. Rio de Janeiro: Imago, 1976. (p.374-375).

29 "A castração é ao mesmo tempo o quinhão comum, isto é, o Fálus prevalente e transcendental, e a distribuição exclusiva que se apresenta nas meninas como desejo do pênis, e nos meninos como medo de perdê-lo ou recusa da atitude passiva. Esse algo em comum deve fundar o uso exclusivo das disjunções do inconsciente - e nos ensinar a resignação: resignação a Édipo, resignação à castração, renúncia para as meninas ao desejo de pênis, renúncia para os meninos ao protesto masculino, em resumo, 'assunção do sexo'." Deleuze, Gilles. Guattari, Félix. O Anti-Édipo. Capitalismo e Esquizofrenia. Rio de Janeiro: Imago, 1976. (p.81). A este respeito, há uma especial citação neste livro sobre um parágrafo de Em Busca do Tempo Perdido, em que os autores se deliciam (haja vista a desforra no uso do itálico) com uma rigorosa expiação de Proust para com as normatizações comezinhas da sexualidade de padrões. Segue: "Outros, tendo os sentidos mais violentos, sem dúvida, dão ao prazer material imperiosas localizações. Estes chocariam, talvez, por suas confissões, a média do mundo. Eles vivem talvez menos exclusivamente sob o satélite de Saturno, pois para eles as mulheres não estão inteiramente excluídas como para os primeiros (...) Os segundos procuram aquelas que gostam de mulheres, que podem arranjar-lhes um rapaz, aumentar o prazer que eles têm de estar com ele; mais ainda, eles podem da mesma maneira, ter com elas o mesmo prazer que com um homem (...) Pois nas relações que eles têm com elas, eles representam, para a mulher que gosta de mulheres, o papel de uma outra mulher, e a mulher lhes oferece ao mesmo tempo, mais ou menos o que eles acham em um homem (...)". Ibidem, (p.95). Uma imperiosa confusão onde, em certa altura, já não se sabe muito bem o que é homem, o que é mulher.

30 "Amores não figurativos, índices de um investimento revolucionário do campo social, e que não são nem edipianos nem pré-edipianos já que isso é a mesma coisa, mas inocentemente anedipianos, e que dão ao revolucionário o direito de dizer "Édipo, não conheço". Desfazer a forma das pessoas e do ego, não em proveito de um indiferenciado pré-edipiano, mas das linhas de singularidades anedipianas, as máquinas desejantes. Pois existe realmente uma revolução sexual, que não concerne nem aos objetos, nem às metas, nem às fontes, mas apenas à forma ou aos índices maquinísticos." Deleuze, Gilles. Guattari, Félix. O Anti-Édipo. Capitalismo e Esquizofrenia. Rio de Janeiro: Imago, 1976. (p.464-465).

${ }^{31}$ Haraway, Donna. Donne, Tecnologie e Biopolitiche del Corpo. Milão: InterZone, 1995.

32 "Essa questão sexual no ambiente virtual da cibercultura já foi tratada por muitos pesquisadores das novas tecnologias, até mesmo por algumas feministas que a consideram como uma oportunidade para superar as diferenças de gênero. A indefinição sexual, ou androginia digital, aparece como uma disposição psicológica facilitadora da adaptação a contextos sociais diversos. Um indivíduo andrógino se adapta a situações, características e disposições do outro sexo. Pensa-se, assim, que o indivíduo tem opiniões e comportamentos mais igualitários. Nessa perspectiva, os chats com seus jogos intersexuais e andróginos, conduzem a fraturar o pressuposto de que a masculinidade e a feminilidade sejam duas entidades separadas e incompatíveis. Os indivíduos seriam criados, assim, sobre uma maior margem de tolerância, na medida em que suas práticas rechaçam a dependência a contextos que impliquem leis especificamente masculinas ou femininas. Segundo Malcolm Parks, autor de um estudo sobre os jogos de personificação de sexos na Internet e professor da Universidade de Washington, a 'Internet é um lugar maravilhoso para escapar das categorias sexuais. É um lugar em que as personas não têm que se comportar como realmente são. A Web pode ser comparada a um baile de máscaras e disfarces'. Cuatro de cada 10 cambian sexo en internet. Terra, 23/05/2000." La fantasía y los afectos en el chat. IN: Sánchez, Antulio. La era de los afectos en internet. México: Editorial Océano, 1997. 


\section{O BURACO NEGRO DA DESCENTRALIZAÇÃO}

Buraco, substantivo masculino:

Espaço vazio, oco, orifício. Sentimento de falta ou de perda de alguma coisa ou pessoa; vazio, falta, vácuo. Rubrica: física da matéria condensada: sítio de uma rede, caracterizado pela ausência de um elétron num semicondutor, cuja ocupação por um elétron de um sítio vizinho cria uma nova vacância e estabelece um comportamento equivalente ao de uma carga positiva que se move; lacuna.

Rubrica: artes gráficas, jornalismo: espaço vazio por falta de matéria ou por erro de diagramação. Regionalismo: Portugal. Uso: linguagem de delinqüentes: Penitenciária (1938).

Dicionário Houaiss da Língua Portuguesa ${ }^{1}$

Trying not to be a Nazi approximates one to Nazism far more radically than any irresponsible impatience in destratification. Nothing could be more politically disastrous than the launching of a moral case against Nazism: Nazism is morality itself.

Nick Land ${ }^{2}$

Uma questão recorrente a respeito das comunidades virtuais é como um agrupamento inicialmente inovador, um espaço de autonomia expressiva temporária, torna-se um agrupamento fechado, autoritário e excludente ${ }^{3}$. Isto é, como conseguem as microcélulas alternar investimentos de desejo tão díspares e contraditórios. A isto não basta o conselho do bom cidadão, daquele que crê que alguma flexibilidade, muita conversa e um pouco de bom-senso pode a tudo resolver. Isso porque a formação autoritária independe da linha política geral que um grupo adota, ou seja, antes do autoritarismo tomar uma dimensão propriamente política, ele se desenha por conjugações moleculares, microformações subjetivas. São spots de guerra incondicional, máquinas desejantes que agarram linhas destrutivas, pequenos buracos negros que se somam e formam uma cratera. Não que estas linhas desejem sua própria destruição, em um improvável ato suicida. Ocorre que destruição e domínio são elementos constituintes de toda máquina desejante, sobretudo as de guerra. ${ }^{4}$

Hermano Vianna, antropólogo e articulista do jornal Folha de São Paulo, narra em artigo de $1994^{5}$, os novos problemas dos meios novos, os digitais. Escreve que em uma lista de discussão (mailing list) 
ocorrera uma briga entre os moderadores que resultou em uma intrigante composição de forças e de repressão. O assunto que a lista de debates abordava era, ironicamente, Gilles Deleuze.

Vianna conta a história como uma revolução popular bizarra. Essas listas de discussão - como a que trata o caso - são bastante intensas e conhecidas na Internet por oferecerem um ambiente propício ao debate sério, havendo o tipo de conteúdo complexo que os outros media jamais conseguiram proporcionar. Indicando que as melhores listas são as que contêm um moderador (figura que pode banir um usuário da lista e fazer triagem nas mensagens que chegam, enfim, um usuário que detém poder), Vianna faz um balanço sobre a dose desejável para quem cumpre a função:

Os moderadores surgiram justamente para tentar conter o desperdício de 'largura de banda' que engarrafa a Internet com mensagens idiotas e brigas enfadonhas. E pior: as 'flames' inundam com gigabytes de lixo as caixas postais de usuários bemintencionados que, traumatizados, nunca mais ligam seus modems ou cancelam suas assinatura de listas para as quais poderiam dar importantes contribuições. O difícil é estabelecer os limites para a atuação moderadora. Alguns list-owners são ditadores extremistas: só são distribuídas na Rede as mensagens que julgam apropriadas. Outros moderadores, melhores, se contentam com um poder sutil. 'Conduzem' a conversa e tentam encontrar maneiras para contornar eventuais problemas. Era isso que acontecia na lista deleuze. Até algumas semanas atrás. ${ }^{6}$

A definição do que configura um problema para a lista pode gerar debates intermináveis, usualmente poupados com uma mensagem de boas-vindas em que as regras da casa são imediatamente expostas. Quando as regras não são claras ou moderador atua arbitrariamente, é freqüente a lista ser atravessada por um furacão que divide os usuários em blocos pró e contra. Não que resolva o problema, mas parece entusiasmar a todos. Isso porque a Internet, unindo pessoas de culturas, estilos de vida, orientação política e educação absolutamente diferentes, fomenta um ambiente em que o conflito, inevitável, também é combustível para discussão.

Basta o moderador não ter muita sensibilidade para uma eventual discórdia que uma avalanche de dissensões apareça, estranhamente, do nada. Estranhamente porque por ser um meio ainda novo, suas regras de funcionamento não são claras, e sua estrutura de descentralização radical imediatamente inviabiliza a censura e o direcionamento forçado a temas ou atitudes. Vianna diz que a Internet é uma espécie de experiência civilizatória num território selvagem. Não existem regras gerais de convivência. Essas regras são criadas a cada interação ${ }^{7}$.

Assim, a lista sobre o filósofo Gilles Deleuze também tinha seu moderador, que por sua vez era subordinado a outro moderador: o administrador da infinidade de listas de discussão alojadas no servidor. Ocorre que este administrador resolveu intervir em certa discussão, alegando que tal debate era inútil à 
lista porque "poético", tendo pouca relação com a filosofia deleuzeana. A intervenção rachou a lista, dando início a uma série de mensagens acusando o moderador de fascista, ditador e assim por diante.

Uma situação não de todo atípica, pois as divergências sobre como se conduzir o debate são muitas vezes o tempero que o próprio grupo faz uso para se diferenciar. Na lista em questão, o moderador formou um grupo de insurgentes com o moderador de outra lista, sem consultar a comunidade e produzindo o que Vianna chamou de Golpe de Estado Eletrônico, consequiência da instalação de um software dentro do servidor que não estava conjugado ao sistema do administrador.

O administrador, em retaliação ao rebeldes, resolveu suspender o funcionamento de todas as demais listas do servidor, que são muitas além da referida lista sobre Deleuze, inclusive listas de seu interesse particular, que o antropólogo lembra com ironia, tratava de Auto-organização e Teoria do Caos. Hipernonsense:

$E$ É interessante ver toda esta trama se desenrolar dentro de uma lista deleuziana. A Internet pode ser pensada como um exemplo mais que perfeito dos rizomas tão elogiados pela dupla Deleuze/Guattari. As ironias (ou pseudo-ironias) se amontoam: a maquinação rizomática da Internet foi criada por militares americanos obcecados com o comunismo. Mas não é sempre assim? A centralização não vai sempre conviver com as tendências descentralizadoras e vice-versa? A produção do corpo sem órgãos não traz sempre consigo o risco de descambar num buraco negro fascista? ${ }^{8}$

Vianna lembra que a Internet não vai resolver os problemas políticos e organizacionais do poder na sociedade, e que longe de concentrar o paraíso da anarquia virtual, reproduz e (re)trabalha as relações de poder em que estamos todos submersos. Apesar de o ambiente virtual estar prenhe das prerrogativas e formas hierárquicas de poder, também é certo que a maneira pela qual elas se desenvolvem, e sobretudo as condições de resposta que são alimentadas pelo medium, não apenas evocam certas nuanças, certas aberturas imperceptíveis: o medium produz uma ordem ligeiramente estranha porque suas trilhas são rizomáticas. Funciona rizomáticamente, um Corpo sem Órgãos (CsO), local onde diversas linhas e fluxos são atravessados, percorridos, sem um signo que lhes coordene centralmente. Tecnologia de teia:

Mas o que é um corpo sem órgãos? Também a aranha nada vê, nada percebe, de nada se lembra. Acontece que em uma das extremidades de sua teia ela registra a mais leve vibração que se propaga até seu corpo em ondas de grande intensidade e que a faz, de um salto, atingir o lugar exato. Sem olhos, sem nariz, sem boca, a aranha responde unicamente aos signos e é atingida pelo menor signo que atravessa seu corpo como uma onda e a faz pular sobre a presa. (...) a teia e a aranha são uma mesma máquina (...) são como reações globais intensas do corpo sem órgãos a signos de diversas naturezas. Esse corpo-teia-aranha se agita para entreabrir ou fechar cada uma das pequenas caixas que vêm deparar-se com um fio viscoso. ${ }^{9}$ 
A Internet oferece uma metáfora perfeita do perigo recorrente de um corpo sem órgãos descambar para um buraco negro fascista, como lembra Vianna. Entretanto, essa corrupção no sentido da experiência vivida não pode ser subsumida dentro de uma explicação meramente macropolítica: há variantes de desejo, de pulsão. A filosofia de Deleuze assinala que todo fascismo é uma questão de desejo ${ }^{10}$, mas é importante lembrar, freudianamente, que as criações técnicas da civilização, por pacíficas e admiráveis que sejam, guardam sempre o conflito pulsional inerente à natureza humana. E é esta segunda que sempre vence.

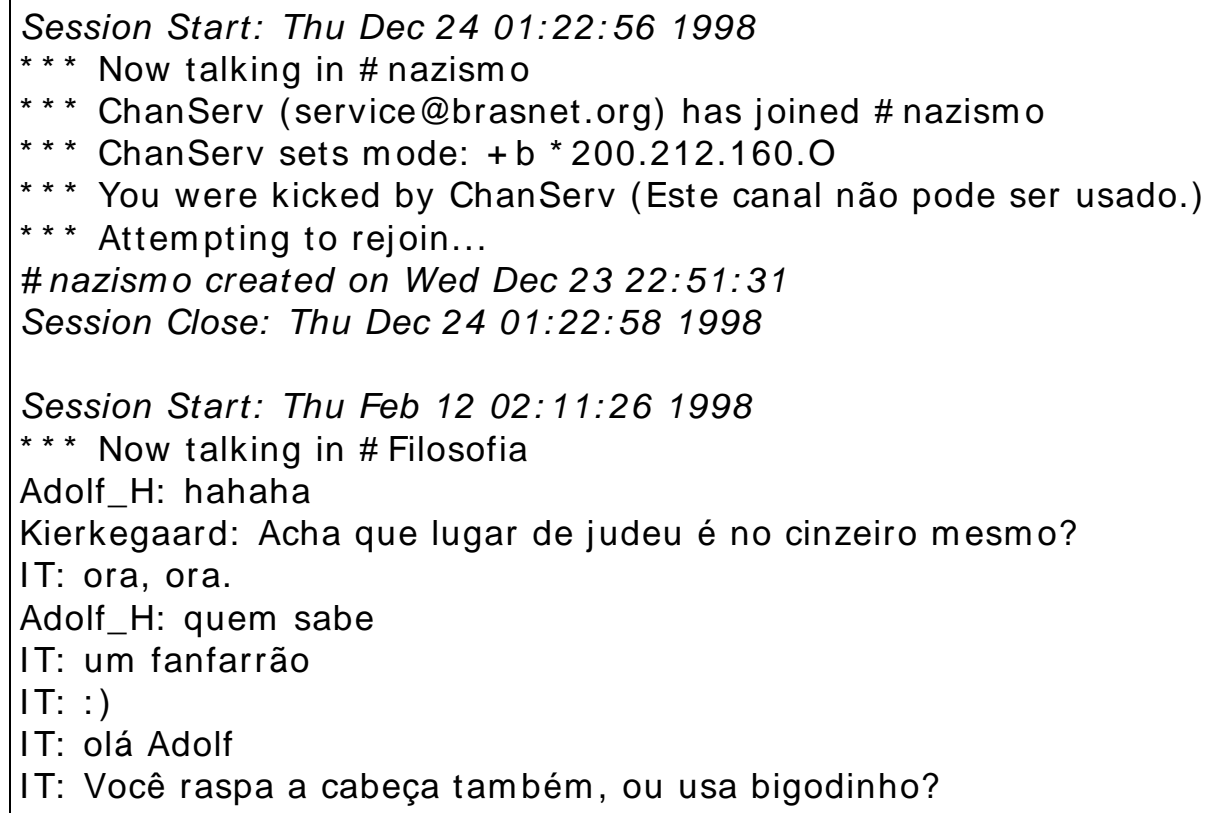

Corte para:

Session Start: Thu Feb 12 02:11:26 1998

*** Now talking in \# Civilização

* * Topic is 'Se você é contra nordestinos que vem pra Sampa roubar emprego entre aqui'

* * * Set by ${ }^{\wedge} \mathrm{OvErDoSe}^{\wedge}$ on Wed Feb 11 22:22:29

\# Civilização created on Wed Feb 11 22:17:46

* * * Retrieving \# Civilização info...

hittler: *Para entrar no meu Fserver, escreva: !belasfotos*

hittler: *Estou servindo: Fotos de famosas (Carla Perez, Sheila Melo, Xuxa)

Corte para:

Session Start: Wed Dec 23 23:06:16 1998

DCC Chat session - Client: hittler

Acknowledging chat request... DCC Chat connection established.

hitler: Os judeus foram mortos simplesmente porque não se tinha como alimentar 4 milhões de judeus. Logo, o mais fácil era matá-los já que não se tinha afeição por eles, até com certa razão.

Fade in:

Session Start: Thu Dec 24 01:43:14 1998

*** Now talking in \# neo_nazismo

\# neo_nazismo created on Wed Dec 23 22:51:49

HerrK: E você barbous, qual seu nome completo?

barbous: Leonardo da Fonseca Barbosa (português)

HerrK: não diga! Barbosa? Mas isso não é novo-cristão (Judeu)?

HerrK: Um judeu nazista? 
barbous: Tenho parentes na Itália, Portugal e Alemanha.

barbous: NUNCA!

$\wedge$ WolfShade^ : novo-cristão

BELI AL: JUDEU??

barbous: NUNCA!!!!!

$\wedge$ WolfShade^ : Novo-Cristão Português. É Português, mas reformado.

HerrK: não são os sobrenomes referentes a plantas, animais ou acidentes geográficos o resultado da cristianização dos judeus? i.e. barbosa, oliveira, etc.

$\wedge$ WolfShade ${ }^{\wedge}$ : sim, na inquisição todas as famílias judaicas foram obrigadas a trocar de nome

^ WolfShade^ : virando 'costa', 'paredes', nomes relacionados a objetos e locais específicos.

HerrK: Bastante estranho isso, barbous. a título de curiosidades, você tem ascendência judaica?

^ WolfShade^ : tras-os-montes é onde se refugiaram todos os judeus que habitavam Portugal na época, e lá foram obrigados a trocar de nome

barbous: não. Felizmente não. Minha família é toda católica. Menos eu. Sou ateu

HerrK: sim, você é judeu...

barbous: não!!!

^ WolfShade^ : barbous: Conheço bem a história de Portugal, sou obrigado a concordar com HerrK.

Herrk: Como é ser um nazista-judeu? Um paradoxo, não?

barbous: não. estou certo do que falo!!!

HerrK: imagine o que seus ancestrais, que mais tarde viveriam o holocausto, não achariam disso?

^ WolfShade^ : os Judeus ibéricos foram afetados mais pela inquisição do que pelo holocausto...

barbous: Não. Meu pai também é nazista. E meu avo também.

HerrK: Compreendo. Assim como seu bisavô, seu tataravô, etc. etc. Talvez o saudoso Jacob fosse

também um nazista, é isso?

^ WolfShade^ ${ }^{\wedge}$ são sepharadis. E, nessa época, já estavam reformados e tal. O sepharadi é judeu, porem novo-cristão e não mais "considerado" como.

barbous: O sangue se purifica. Se a tua história é correta, já sou puro (apesar de afirmar não haver judeus em minha família)

HerrK: O que significa um judeu puro?

barbous: não sou...

Session Close: Thu Dec 24 02:49:29 1998

Pois como debatemos no capítulo precedente, o medium viabiliza a formação de agregações que não se sujeitam ao controle central. Em termos psicanalíticos, à função paterna. Essa composição, aparentemente inexplicável, reflete pressupostos lógicos particulares às formações rizomáticas. São agregações velozes, muitas vezes de nonsense, que em determinado instante se apresentam originais e inovadoras, mas conservadoras e repressivas em outros. Por isso, é comum que os grupos consolidem certa unidade, criando líderes ou figuras que magnetizam os demais. Não é exatamente um retorno da figura paterna, é uma figura que canaliza comportamentos e tendências e que opera com uma margem de poder algo mítica, inefável.

Mesmo que essa função de condutor do bando seja exercida por lateralidades, freqüentemente observamos essa função ser magnificada pelos mecanismos da mitificação. São maneiras de administrar uma exuberância de atos e concepções, que faz com que o grupo gravite em torno de algumas coordenadas. O Mestre, assim, vai colhendo os frutos produzidos pela fundação do mito, singularizador e eternizante. Diante da inevitabilidade do fascínio que se exerce sobre o fascinado, podemos aventar a questão de como estes grupos se forjam sem caírem nas armadilhas do populismo e do carisma rasteiro, os conhecidos riscos da politização pela exuberância. 
Nem toda descentralização é criativa. O colapso da função paterna não é necessariamente um engenho civilizatório, pois pode se transformar na reprodução intermitente dessa ausência em modalidades de todo destrutivas. Falamos das agregações em que, rapidamente, emerge uma potência autodestrutiva geradora de abismos, potência que ignora a alteridade. Acontece quando um membro do bando decide que alguém ou um grupo restrito de pessoas é superior aos demais, desvencilhando-se da rede e procurando ocupar uma posição de soberania em relação aos irmãos do grupo ${ }^{11}$. É a instauração dessa figura de auto-suficiência no espaço social que viabiliza a realização da repressão sem lei, ou seja, da barbárie.

$[0: 38-0: 40]$

Merlin: você ta dando mole, para com isso, numa boa...

cMoojz: Você ta se estressando, para com isso, numa boa...

cMoojz: Censure se quiser, use o kick/ban. Afinal, o poder é seu, use-o como quiser

Merlin: a questão não é poder, a questão é ordem !!

Corte para:

$[2: 03-2: 14]$

Maryanne: olha, essas coisas todas me enchem a paciência.

Maryanne: às vezes uma @ sobe a cabeça.

Diabow: Posso ver. Já tentou outros servers?

Maryanne: como assim?

Maryanne: Ahh! Estou sempre em 2 ou 3 até ser banida de todos.

A castração é a função que possibilita a inserção do indivíduo na ordem da Lei, dentro do princípio de realidade - apartando-o do império desejante do princípio de prazer. Tanto o corte simbólico quanto a função paterna não precisam ser necessariamente exercidos por um pai real físico. O problema da ausência ou a progressiva elipse da estrutura edipiana em agentes cada vez menos avessos a estruturas, é a possibilidade de a castração normativa vir a falhar. Sem ela, desaparecem as possibilidades de se introduzir dentro do bando o aspecto mais radical da convivência, que é a semelhança na diferença, e que só pode ser feito pela inclusão do outro, do diferente, em modalidades de compartilhamento e na troca de referências, contribuindo para impedir que os grupos ou os bandos acabem se tornando agrupamentos identitários, com uma marca indivisível, dando margem para fanatismos e intolerâncias de toda ordem. Este é o enredo da conhecida história de horror à alteridade, ou seja, à castração.

Léa Waidergorn, em seu livro sobre comunicação eletrônica ${ }^{12}$, reproduz uma discussão ocorrida na BBS CanalVIP, pelos idos de 1994. Os trechos que o livro traz do Caso Gustavo são sintomáticos do tipo de disjunção e criação de grupelhos em torno de pequenas questões que se transformam em diferenças vitais. Gustavo, que havia erroneamente inserido uma mensagem publicitária em um canal de discussão, rapidamente se torna alvo da maioria dos participantes. Tentando rebater sozinho uma grandeza esmagadora de críticas que vão aparecendo, Gustavo envia uma mensagem com o sugestivo título de "Sociável" para os participantes. Remontando a uma suposta lei em que "os semelhantes atraem os 
semelhantes", alega que os indivíduos se agregam segundo recursos mentais semelhantes, dando a entender a seus detratores que algo de errado estava acontecendo naquele montante homogêneo de críticas. Dissimuladamente, Gustavo quer insinuar que a facilidade com que foi criada uma sociabilidade de ataque a ele pelo grupo, é resultado da homogeneidade média do grupo, propenso a não tolerar grandes diferenças em prol do fomento às afinidades psicológicas. Chega mesmo a ofender seus detratores como "medíocres".

Recebe mais mensagens contra. $\mathrm{O}$ argumento agora é democracia e direito das maiorias, que então é rebatido por uma interpretação livre do filósofo Friedrich Nietzsche. Gustavo parece até gostar do debate. Alex, que tenta apaziguar os ânimos, recebe uma reprimenda de seu companheiro Luiz, que alega que "os fatos da vida" levam a um protocolo ancestral em que a cumplicidade é o primeiro valor em qualquer comunidade. Diz isso durante uma interessante pregação em que o companheirismo aparece como o sentido na luta pela vida. Assim, faz apelo lembrando daqueles que entrarão na briga a seu lado, sem perguntar se você tem razão ou não. Falo daqueles que darão e levarão porradas por você e com você. Falo da "turma" e dos amigos ${ }^{13}$. Enumera exemplos do seu evolucionismo desajeitado, da coragem e fidelidade canina ao nacionalismo impetuoso, e finaliza dizendo que a posição de seu companheiro nunca o qualificará como amigo de fé, nem como alguém de confiança de um grupo que se proponha a uma jornada ${ }^{14}$. Para fazer parte do grupo, não há duvidas, é preciso aderir, seja ao que for.

O Caso Gustavo enquadra-se dentro de uma infinidade de celeumas onde ocorrem formações de grupos em prol de uma idéia. Interessante é notar que Gustavo, em nenhum instante, contou com o apoio de outro associado, tendo que permanecer só na briga e mais tarde fazendo disso uma bandeira. Normalmente assistimos a formação de duas ou mais "equipes", com vários integrantes, possibilitando que a discórdia não acabe.

A briga toda tem fim com uma mensagem de Gustavo para todos os usuários, com o título de Mensagem aberta para todos os veteranos e novatos do CanalVIP:

Sou um novato aqui no CanalVIP. Parece-me, também, que, desconhecendo algumas normas, ultrapassei minha prerrogativa - coloquei um inocente anúncio na conferência errada. Porém, mediocres incapazes de compreender e de assimilar, como de se adaptar às aquisições e às idéias recentes, tornam-se rotineiros e hostis às inovações progressistas. Daí o sentimento de repulsa que demonstram a tudo que é novo, motivo principal da tendência conservadora das massas. Conhecem-se medíocres que não se conformam com o anonimato; sofrem a obsidência de se tornarem "importantes" $e$ "populares"; fazem o que podem para sobressair, usando as armas prediletas do embuste e do cabotinismo. Daí a multiplicação deles em torno de uma questão que é particularmente irrelevante, já que não conseguem farejar questões de primeira importância. Pois, então, eu lhes digo uma questão de primeira importância: lutem sozinhos. Esse, sim, é o pressuposto inicial de uma natureza grande. ${ }^{15}$ 
Apenas uma visão inteiramente idílica ou ideológica pode entender as manifestações pós-modernas como necessariamente boas ou progressistas. O conselho de Tácito sobre a narração e a escrita da história, que deveria ser feita sine ira et studio (sem ódio nem parcialidade), indica que a tarefa de compreender não se coaduna com a de julgar. Interpretar pressupõe valorações em categorias, mas assim como as Eras se sobrepõem em temporalidades entremeadas, o esgotamento de um modelo não implica no surgimento de substitutos criativos. Ao contrário, é recorrente a apropriação de padrões precedentes para fins distorcidos e imediatistas, comumente agenciados segundo as maneiras mais abomináveis de vivência. A Internet não constitui exceção, a despeito da descentralização e quebra da linearidade. De fato, o negativo toma contornos de todo sombrios no mundo digital, pois o indesejado não é apenas omitido, é deletado, não está previsto no código e simplesmente não existe. Assim, a suposição de que a Inteligência Artificial, as Comunidades Virtuais ou as demais insurgências da Era Tecnológica trazem consigo uma necessária força inovadora e positiva só pode ser orquestrada dentro do imperativo ideológico que conhecemos por "progresso".

Da mesma maneira, a falência do modelo de família nuclear ${ }^{16}$ como agenciamento subjetivo não implica necessariamente em agregações inovadoras, estas positivas e libertárias, mas antes, em formas de apropriação desse cenário corroído para o saneamento de demandas que se pensavam superadas, em um movimento marcadamente conservador. Podemos observar este fenômeno na conjuntura atual, em que a inoperância da célula familiar em sua função mais importante, que é a de agenciar subjetivamente seus integrantes, não provocou nenhuma ordem social revolucionária ou inovadora, mas tentativas de se reaver o patrimônio familiar tal como outrora funcionalizado, entendido dentro dos parâmetros tradicionais. O exemplo máximo dessa operação é sem dúvida o crescimento das frentes evangélicas, verdadeiros levantes pela família tradicional que operam como uma irmandade ansiosa pelo padrão perdido e corrompido. São verdadeiras máquinas de vivência de um modelo subjetivo ameaçado, cujo esquecimento é apenas temporário. Levante, afinal, não é uma propriedade única da criatividade.

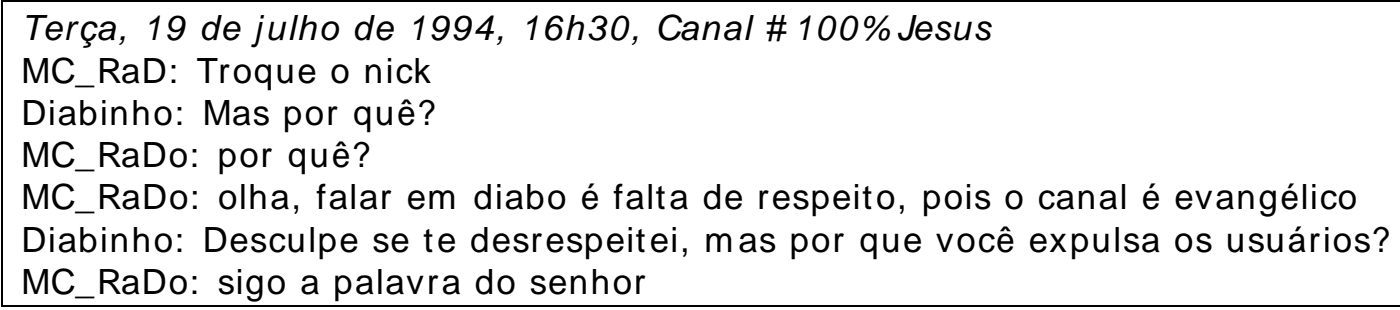

Deleuze retoma insistentemente a advertência de que o risco de um Corpo sem Órgãos se tornar um buraco negro fascista é permanente. Desejo não é necessariamente desejo de criação, de construção. Pode perfeitamente ser desejo de destruição ou de aniquilamento. Nessa perspectiva, que não admite a concepção de manipulação ou de espetáculo falseado, a máquina atravessada por linhas de 
agenciamentos criativos é a mesma que é atravessada pela vontade mais irresistível de aniquilamento, de negatividade.

Por que isso ocorre é uma das falsas questões, como diria Bergson. Ou seja, é uma questão que só tem sentido quando se pensa que o desejo de criação é anterior ou mais necessário que o de destruição, quando há a impossibilidade de se tomar uma manifestação com significação autônoma. Como isso ocorre é que configura questão, pois mesmo o inconsciente não coloca nenhum problema de sentido, mas unicamente problemas de uso. O problema do desejo não é 'o que isso quer dizer?' mas como isto funciona. $^{17}$

Uma máquina de guerra nômade se caracteriza pela mobilidade e facilidade em formar novas células, ou seja, por uma dinâmica veloz com capacidade ótima de agregação e dispersão. Ocorre também destas máquinas nômades serem apropriadas por um aparelho territorializado, como o estatal. Guerra. Acontece quando a linha nômade, mercenária, é conjugada em um território sistematizado e delineado. Mercenários que viram soldados, nômades assalariados, transição de uma fórmula a outra. A constituição da instituição militar, do exército, passa pela tarefa de formar um bloco, um grupo fechado que não pode admitir uma máquina de guerra nômade.

Assim, a questão que submerge ao desejo de controle não é uma questão apenas macropolítica. Nem tampouco sumariamente micropolítica. Tais afecções remetem à complexa teia de sentimentos que nossas máquinas produzem. O paradigma humanista da fraternidade e do amor universal, essencialmente cristão, embaça um pouco a compreensão dessa economia. Embaça porque o desejo não é necessariamente de amor entre os irmãos. Nada há de errado em se desejar a destruição, mesmo porque não há nada de estranho em se desejar a morte. É um desejo como outro qualquer. Destruição e Vida não são apenas duas faces da mesma moeda, são ainda pólos de agenciamento co-dependentes e imprescindíveis ao universo de deslocamento que o desejo percorre intermitentemente. Se podemos ver nos chats como a comunicação se alterna entre desejo de vida e desejo de destruição - mesmo de autodestruição - é simplesmente porque desejar estará sempre acima dos pressupostos morais que, neste caso, são os do humanismo, do iluminismo e do progresso.

[01:35]

UNAGUNNA: você é Antroposofo, é?

||EU||: ainda não tenho acesso a tais níveis transcendentais de sapiência que vossa majestade tem. UNAGUNNA: eu sei meu filho

||EU||: não, já estudei algumas coisas tipo budismo, teosofia, algumas sociedades secretas, etc. UNAGUNNA: a melhor maneira é repetir 100 vezes ao dia; "EU sou mais EU"

||EU\|: eu acho que a melhor maneira é obter conhecimento de que as pessoas são em maioria muito burras e medíocres além de impuras, e isso eleva a auto-estima naturalmente

||EU | : ou pelo menos baixa a auto-estima das pessoas todas junto com a sua [01:37] 
Esta abordagem, notadamente nietzscheana ${ }^{18}$, não separa destruição de criação por serem elementos de um mesmo fenômeno, mecanismos da mesma máquina: Máquina de Desejar. Desejo de se destruir pode ser contíguo ao desejo de se reconstruir. Assim como, diferentemente, desejo de se destruir também pode ser um melancólico desejo de não-mais, de além-d'eu: abolição.

Não houve uma manipulação por potências invisíveis, nem mesmo ingenuidade. Houve e há desejo, querer. A infelicidade das análises na e pela estrutura é tentar entender o fluxo como um horizonte reto, linear, seqüencial e lógico. Na pulsão, inversamente, não cabem predicados definitivos. Aqui, o humanismo iluminista peca por acreditar que o social tende ao positivo. Não que o campo social seja imanentemente destrutivo, mas há lógica, coerência e sentido mesmo nos episódios de memória mais triste. Pode-se pregar a boa-vontade, a catequese humanizante, mas de que isso valerá se a desejo quer destruição. E quem pode dizer que o desejo é mau?

A relevância de abordar um tema desses, em um trabalho dessa natureza, é apenas aparentemente dissonante. Todos que travaram conhecimento com o objeto em questão - salas de comunicação virtuais - puderam perceber quão proeminente são as relações de força e de poder. E quão perversas elas podem ser. Os trabalhos sobre os chats invariavelmente encontram e trabalham essa questão ${ }^{19}$, pois a dinâmica de poder - aceitação de um indivíduo ou banimento, recusa do outro, que na vida real é polidamente administrada, adquire no universo virtual uma brutalidade exacerbada, franca e impiedosa. O que os olhos não vêem, o coração se permite impiedosamente.

Fala-se em "comunidade virtuais" pela óbvia razão de que são agregações que procuram se estruturar compartilhando vivências e modelos - alternativos ou não - de vida ${ }^{20}$. Encontra-se na bibliografia sobre o tema um recorrente traço comunal nos primeiros cidadãos virtuais, atribuídos à grande vazão de usuários provindos da contracultura, com seus fóruns de debates sobre questões sociais, espirituais ou culturais, voltadas à construção de uma nova sociedade. Num segundo momento, em que a Internet é aberta a maiores parcelas da população, surgem dessemelhanças entre os grupos de usuários, que agora também são formados por jovens, sobretudo geeks, ávidos por discutir questões concernentes ao cotidiano da adolescência, como drogas, sexo, escola ou família.

A dinâmica social que se estabeleceu entre os dois grupos foi de conflito constante. Como as preocupações entre os grupos são bastante diferentes entre si, a hostilidade e a disputa pelo comando do espaço que não existe, que não é sólido, ganhou corpo e tomou o cotidiano da territorialidade virtual. Apesar do enfrentamento corrente, os grupos não estabeleceram meios ou estratégias de convivência recíproca, não houve tentativa de abertura ao outro grupo. Pudemos observar que, aos anteriores espaços 
de liberdade e expressão livre, criam-se técnicas e maneiras de controle, de restrição de uso e acesso no ambiente virtual. Essa constante e aparentemente inevitável necessidade de negativizar o outro é o que Freud chama de "narcisismo das pequenas diferenças":

\begin{abstract}
Evidentemente, não é fácil aos homens abandonar a satisfação dessa inclinação para a agressão. Sem ela, eles não se sentem confortáveis. A vantagem que um grupo cultural, comparativamente pequeno, oferece, concedendo a esse instinto um escoadouro sob a forma de hostilidade contra intrusos, não é nada desprezível. É sempre possível unir um considerável número de pessoas no amor, enquanto sobrarem outras pessoas para receberem as manifestações de sua agressividade. Em outra ocasião, examinei o fenômeno no qual são precisamente comunidades com territórios adjacentes, $e$ mutuamente relacionadas também sob outros aspectos, que se empenham em rixas constantes, ridicularizando-se umas às outras, como os espanhóis e os portugueses, por exemplo, os alemães do Norte e os alemães do Sul, os ingleses e os escoceses, e assim por diante. Dei a esse fenômeno o nome de 'narcisismo das pequenas diferenças', denominação que não ajuda muito a explicá-lo. Agora podemos ver que se trata de uma satisfação conveniente e relativamente inócua da inclinação para a agressão, através da qual a coesão entre os membros da comunidade é tornada mais fácil. Com respeito a isso, o povo judeu, espalhado por toda a parte, prestou os mais úteis serviços às civilizações dos países que os acolheram; infelizmente, porém, todos os massacres de judeus na Idade Média não bastaram para tornar o período mais pacífico e mais seguro para seus semelhantes cristãos. Quando, outrora, o Apóstolo Paulo postulou o amor universal entre os homens como o fundamento de sua comunidade cristã, uma extrema intolerância por parte da cristandade para com os que permaneceram fora dela tornou-se uma conseqüência inevitável. Tampouco constituiu uma possibilidade inexeqüível que o sonho de um domínio mundial germânico exigisse o anti-semitismo como seu complemento, sendo, portanto, compreensível que a tentativa de estabelecer uma civilização nova e comunista na Rússia encontre o seu apoio psicológico na perseguição aos burgueses. Não se pode senão imaginar, com preocupação, sobre o que farão os soviéticos depois que tiverem eliminado seus burgueses. ${ }^{21}$
\end{abstract}

Günther Anders, ao tratar dos meios de comunicação na segunda revolução industrial, diz que a lógica de integração dos media realiza uma completa submissão às práticas e aos processos sistêmicos, mesmo quando aparentemente se trata de pura ação, ato total. Assim, não importa exatamente qual função a ser exercida, pois seja ela qual for, já se encontra previamente alinhada a uma imensa operacionalidade que só faz submeter. Para Anders, tanto estar aberto ao outro quanto ser por ele calado fazem parte do mesmo processo de neutralização dos media, que não permite a distância comunicativa necessária para expressão da dissonância e que, em última instância, inviabiliza a existência da diferença ${ }^{22}$. Paralela e inversamente, nos termos humanistas dos estudos culturais, isso implica no debatido reconhecimento das diferenças, conquanto que sem conflito: traz-se para o campo cultural toda sorte de conflitos justamente para que não sejam abordados, pois contíguo ao suposto reconhecimento emerge uma operacionalidade de "distâncias saudáveis", que não permite a partilha do mesmo solo e para o qual diferença tem um sentido bastante singular: apartamento. 
[02:37]

*** MonsterMor entrou no \# Poesia

MonsterMor: Farbach qual sua idade?

Farbach: 20, com cara de 20.

MonsterMor: quando o desejo se apresenta eu o

ataco com todas minhas forças

MonsterMor: "gozar quando tantos sofrem"

MonsterMor: fatal.

MonsterMor: vou nessa...

Farbach: ahãm

MonsterMor: to bêbado hoje, bebi vinho.

MonsterMor: não costumo falar tanto

MonsterMor: muito menos em publico

Farbach: só

MonsterMor: obrigado por ter paciência

Farbach: vai lá mano

* * * MonstroMor deixou o \# Poesia

Sessão finalizada: Fri Jul 05 03:20:56 2002
Mas se entendemos os chats como um meio de todo distinto, que pode agenciar espaços de criação e originar expressões e modelizações inovadoras, como pode ele vir a produzir, por inversão, execrações devastadoras? Afinal, como pode um ambiente formado por um mesmo grupo se tornar autoritário de um momento para outro? Como podem agregações antes inovadoras produzirem investimentos tão conservadores, dentro de um espaço temporal tão pequeno, quando não sumário?

As salas de bate-papo muitas vezes criam espaços de autonomia temporária, como vimos no capítulo precedente. São lugares de expansão dos horizontes e dos modelos de vida que tencionam romper padrões. Isso porque a transgressão realizada em grupo, a experiência proibida, faz de todos semelhantes diante do pacto infrator. Problemas de autoridade e superego deixam de ser intra-subjetivos para se tornarem intersubjetivos, algo como um encontro entre semelhantes. Isso se dá quando o indivíduo excluído e solitário encontra-se em um grupo, uma coletividade que produz uma função simbólica. $\mathrm{O}$ problema é quando estas formações, que precisam ser efêmeras, dão lugar ao fanatismo do grupo que se auto-proclama senhor de algo ou alguém. Isso ocorre quando o grupo deixa de servir a uma função de diferenciação e passa a funcionar como meio de não-enfrentamento ao necessário e incontingente desejo individual, espécie de desvio que cria a subserviência cega e fanática ao grupo, com elementos bastante destrutivos.

\section{Session Start: Sun Jan 31 21:57:29 1999}

Mindinho: Estão brincando com você. Feche esses PVTs e ignore-os

Mindinho: Está entendendo?

Shall: Quem é você?

Mindinho: Isso não tem a menor importância.

Shall: Bah, to dizendo

Shall: Isso não vai ficar assim

Mindinho: Bom, faça o que quiser.

Shall: Que coisa babaca. Vão todos pra a-kick

Mindinho: Pois é, cada um se diverte a seu modo. O deles é ficar sacaneando os usuários.

Shall: Por que eles têm que sacanear eu e minha namorada? Eu nunca os vi...

Mindinho: Não sei, acho que por você ter entrado no canal pra dizer besteiras, provavelmente.

Mindinho: Puro acaso... Enfim, isso não tem importância. Não se aborreça.

Shall: Olha cara...

Shall: IRC é fácil... todo mundo brinca com todo mundo.

Shall: Me desculpe, mas vou tomar as providencias que eu posso tomar.

Mindinho: Sim, mas isso é IRC.

Shall: Eu vou tomar as providencias necessárias.

Mindinho: Então tome, oras. Mas não se esqueça que isso não é vida real, não é uma boate ou uma reunião de amigos do futebol. 
As máquinas de guerra não seguem um movimento presumível, planejado. Seus caminhos, suas linhas de fuga, guardam o recorrente perigo de se destruírem depois de algum rompimento, de atravessar as formações duras não em rumo a uma outra linha, mas à abolição plena, ao estático oxidante. Espécie de niilismo realizado, trajeto de intensa abolição interna que faz a morte atravessar de mim para os outros: raios de fogo no horizonte, valetas de sangue em todos os caminhos, e uma dança de possuído dos sobreviventes, daqueles que ainda estão poupados, em torno dos cadáveres ${ }^{23}$. Economia necrógena, de risco total, uma aposta onde a moeda não é a sobrevivência, mas a morte que coroa o perecimento.

\section{NOTAS} ${ }^{1}$ Houaiss, Antônio. Dicionário Houaiss da Língua Portuguesa. São Paulo: Objetiva, 2001.
2 "Negar o Nazismo nos aproxima dele mais radicalmente que qualquer desestratificação impaciente e irresponsável. Nada
poderia ser politicamente mais desastroso que lançar uma cruzada moral contra o Nazismo: o Nazismo é moralidade em si
mesmo". Land, Nick. Making It with Death: Remarks on Thanatos and Desiring Production. Journal of the British Society for
Phenomenology. Machinic Desire, Textual Practice, Jan 1993: (p.471-482).

3 “Assim, não é raro que de uma formação espontânea e informal, na qual semelhantes se agrupam livremente para autorizarse em seu desamparo e em sua diferença, produza-se uma gangue, uma seita, um clã. A segregação, a intolerância e a endogamia são destinos previsíveis para as fratrias que, geradas a partir da diversidade e da mobilidade características das sociedades democráticas, podem se transformar em círculos fechados de proteção imaginária que contrariam justamente as condições de sua origem.” Kehl, Maria Rita (org). Função Fraterna. Rio de Janeiro: Relume Dumará, 2000. (p. 45).

4 “O fascismo é inseparável de focos moleculares, que pululam e saltam de um ponto a outro, em interação, antes de ressoarem todos juntos no Estado nacional-socialista. Fascismo de esquerda e de direita, de casal, de família, de escola ou de repartição: cada fascismo se define por um microburaco negro, que vale por si mesmo e comunica com os outros, antes de ressoar num grande buraco negro central generalizado. Mesmo quando o Estado nacional-socialista se instala, ele tem necessidade da persistência desses microfascismos que lhe dão um meio de ação incomparável sobre as 'massas'. É verdade que as massas não suportam passivamente o poder; elas tampouco 'querem' ser reprimidas, numa espécie de histeria masoquista e tampouco estão enganadas por um engodo ideológico. Mas o desejo nunca é separável de agenciamentos complexos que passam necessariamente por níveis moleculares, microformações que moldam de antemão as posturas, as atitudes, as percepções, as antecipações, as semióticas, etc. O desejo nunca é uma energia pulsional indiferenciada, mas resulta ele próprio de uma montagem elaborada, de um engineering de altas interações: toda uma segmentaridade flexível que trata de energias moleculares e determina eventualmente o desejo de já ser fascista. As organizações de esquerda não são as últimas a secretar seus microfacismos. É muito fácil ser antifascista no nível molar, sem ver o fascista que nós mesmos somos, que entretemos e nutrimos, que estimamos com moléculas pessoais e coletivas.” Deleuze, Gilles. Guattari, Félix. Mil Platôs Capitalismo e Esquizofrenia. São Paulo: Editora 34, 2000 . Vol.3 (p.91-93), consultar também Vol.4, (p.60; p.99) e sobretudo Beasley-Murray, Jon. Deleuze, Guattari and the Human Security System. Literature Program, Duke University. Disponível em: http://lists.village.virginia.edu/ spoons/marxism/jbm.fascism.html

${ }^{5}$ Vianna, Hermano. Novos sistemas, novos problemas - "Revolução" convulsiona o sistema libertário de uma pequena lista de discussão sobre Gilles Deleuze. Jornal Folha de São Paulo, Caderno Mais!, p. 6-8, 17/07/1994.

${ }^{6}$ Idem.

${ }^{7}$ Ibidem.

${ }^{8}$ Ibidem.

${ }^{9}$ Deleuze, Gilles. Proust e os Signos. Rio de Janeiro: Globo, 1981.

10 "Por que os homens combatem pela servidão como se fosse sua salvação? Como se chega a gritar: ainda mais impostos! Menos pão! Como diz Reich, o espantoso não é que as pessoas roubem, que outros façam greve, mas antes que os famintos não roubem sempre e que os explorados não façam sempre greve: por que os homens suportam desde séculos a exploração, a humilhação, a ponto de querer isso, não apenas para os outros, mas para si próprios? Nunca Reich foi maior pensador do que quando recusa invocar um desconhecimento ou uma ilusão das massas para explicar o fascismo, e pede uma explicação pelo desejo, em termos de desejo: não, as massas não foram enganadas, mas desejaram o fascismo nesse momento, nessas circunstâncias, e é isso que é preciso explicar, essa perversão do desejo gregário.” Deleuze, Gilles. Guattari, Félix. $O$ AntiÉdipo. Capitalismo e Esquizofrenia. Rio de Janeiro: Imago, 1976. (p.47). E também: “O CsO (corpo sem órgãos) é desejo, é ele e por ele que se deseja. Não somente porque ele é o plano de consistência ou o campo de imanência do desejo; mas inclusive quando cai no vazio da desestratificação brutal, ou bem na proliferação do estrato canceroso, ele permanece desejo. O desejo vai até aí: às vezes desejar seu próprio aniquilamento, às vezes desejar aquilo que tem o poder de aniquilar. Desejo 
de dinheiro, desejo de exército, de polícia e de Estado, desejo-fascista, inclusive o fascismo é desejo. Há desejo toda vez que há constituição de um $\mathrm{CsO}$ numa relação ou em outra. Não é um problema de ideologia, mas de pura matéria, fenômeno de matéria física, biológica, psíquica, social ou cósmica. Por isto o problema material de uma esquizo-análise é o de saber se possuímos meios de realizar a seleção, de separar o CsO de seus duplos: corpos vítreos vazios, corpos cancerosos, totalitários e fascistas.” Deleuze, Gilles. Guattari, Félix. Mil Platôs - Capitalismo e Esquizofrenia. São Paulo: Editora 34, 2000. Vol.3. (p.28-29). Baudrillard, por sua vez, não se cansa de citar a célebre frase de Barthes, que diz "Não se pode subestimar a capacidade do acaso de gerar monstros". Baudrillard, Jean. Da Sedução. Campinas: Papirus, 1992. (p.157).

11 "Enunciar, portanto, que a ética da fraternidade implica uma política significa dizer que o ideário daquela não é e não pode ser absolutamente contemplativo. Isso porque a possibilidade de usurpação do outro se coloca sempre no horizonte imaginário do sujeito, estando este permanentemente na espreita, podendo se efetivar a qualquer momento. Vale dizer, a fraternidade não é absolutamente uma substância permanente e consistente, mas um estado que pode, contudo, se prolongar ou se dissolver, de acordo com o desejo dos sujeitos que participam nesta rede de laços inter-humanos. Isso porque a qualquer momento alguém ou um grupo de pessoas pode se acreditar superior aos demais, pretendendo sair desta rede e ocupar uma posição de absoluta soberania." Birman, Joel. Insuficientes, um espaço a mais para sermos irmãos! IN: Kehl, Maria Rita (org). Função Fraterna. Rio de Janeiro: Relume Dumará, 2000. (p.186).

${ }^{12}$ Storch, Léa Waidergorn \& Cozac, João Ricardo. Relações Virtuais: O lado humano da comunicação eletrônica. Petrópolis: Vozes, 1995.

${ }^{13}$ Idem.

${ }^{14}$ Ibidem.

${ }^{15}$ Ibidem, p.50

${ }^{16}$ A Revista Época, do grupo Globo, trouxe como reportagem de capa uma pesquisa do IBGE indicando que em metade dos lares brasileiros não mais existe o modelo clássico de família nuclear: "O IBGE acaba de divulgar uma nova análise dos dados do último censo. Ela confirma a mudança, na prática, do conceito de família: atualmente, 47\% dos domicílios organizam-se em modalidades nas quais no mínimo um dos pais está ausente. Há gente morando sozinha, avós ou tios criando netos, casais sem filhos, 'produções independentes' e outras tantas alternativas. Algumas são tipicamente modernas, como os grupos de amigos que decidem morar juntos para dividir um apartamento grande." A Nova Família. Revista Época, no 293, 29/12/2003. p.82-89.

${ }^{17}$ Deleuze, Gilles. Guattari, Félix. O Anti-Édipo. Capitalismo e Esquizofrenia. Rio de Janeiro: Imago, 1976. (p.143).

18 "Vede os bons e os justos, os crentes de toda crença! Quem eles odeiam mais? Aquele que quebra suas tábuas de valores, o quebrador, o infrator: - mas este é o criador". Nota do tradutor: "quebrar, quebrador, infrator" - Zerbrechen (mais precisamente: destruir quebrando), Brecher (o que quebra, infringe a lei), Verbrecher (o delinquiente, o criminoso). Nietzsche, Friedrich. Assim Falou Zaratustra - Um livro para todos e ninguém. Prefácio. Coleção Os Pensadores. São Paulo: Nova Cultural, 1996.

${ }^{19}$ Ver a respeito o trabalho de Ana Maria Silva, que trabalha diretamente com as relações de poder nas salas de bate-papo: Silva, Ana Maria Alves Carneiro. Reconectando a sociabilidade on-line e off-line: trajetórias, poder e formação de grupos em canais geográficos no Internet Relay Chat. Dissertação de Mestrado IFCH/Unicamp - Campinas, Novembro 2000.

${ }^{20}$ Zygmunt Bauman trabalha em seu último livro as novas agregações familiares que escapam ao núcleo triádico convencional. Nele, diz que as relações não são mais abordadas como contratos, parcerias ou uniões, pois as pessoas começaram a enxergar os relacionamentos como ligações; fala-se em "ligar-se" ou "estar ligado" ao invés de "unir-se" e "estar junto". Em vez de parceiros, fala-se em "redes". Assim, a "vida moderna líquida" seria um aglomerado de distintas junções entre "casais semi-separados", "redes de relacionamento", "casamentos tradicionais" e "etc", todos gravitando em torno do medo da dependência, do "até que a morte nos separe". Tais situações, que Bauman descreve como sendo de "laço duplo", remetem à lógica das redes, dos networking. Enquanto reconhece a necessidade de relações duais e estáveis, traça um possível embate de forças entre as pessoas que se vêem nesse tipo de convívio: "No 'mundo de fluxos' em que nada consegue manter sua forma por muito tempo, é preciso muita ousadia para assumir compromissos de longo prazo e, assim, hipotecar futuras oportunidades das quais ainda não podemos saber, mas podemos ter certeza de que surgirão. Quanto mais próximo é um relacionamento, mais ele parece ao mesmo tempo uma promessa e uma ameaça. Não admira que uma 'rede' possa parecer uma alternativa sedutora aos laços. Em uma rede, como você sabe, desligar-se é tão fácil quanto ligar-se.” Bauman, Zygmunt. As novas guerras do prazer. Jornal Folha de S. Paulo, Caderno Mais!, Domingo, 27/06/2004, p.3. Ver a respeito: Bauman, Zygmunt. Amor Líquido - Sobre a Fragilidade das Relações Humanas. Rio de Janeiro: Jorge Zahar, 2004.

${ }^{21}$ Freud, Sigmund. O Mal-estar na Civilização. Rio de Janeiro: Imago, 1974. (p.74-75).

22 "Naturalmente isso soa contraditório. Estar aberto, sem barreiras, para os outros e ser emudecido parecem se excluir mutuamente. Mas só parecem. Pois o emudecimento não aparece apenas quando o abismo entre pessoa e pessoa torna-se tão amplo ou perigoso que não consegue ser superado. Ele ocorre também quando o abismo é muito estreito, para tornar possível uma mediação lingüística. Toda a conversação exige uma distância mínima. O comunicado só tem sentido quando há uma diferença entre o falante e o ouvinte. Quando A, que sabe de alguma coisa, deixa um B, que não sabe, participar de seu conhecimento. Este mínimo de diferença não haverá mais para os congruistas, dos quais se formará a sociedade perfeitamente conformista de amanhã. Pelo fato de todos serem servidos com o mesmo, todos saberão do mesmo. Isso quer dizer: cada ouvinte só poderá ouvir aquilo que ele, da mesma forma, puder falar. E cada um que fala só poderá falar aquilo que ele puder ouvir de outro. Nestas circunstâncias, abrir os ouvidos e a boca não teria mais sentido." Anders, Günther. O antiquiismo do ser humano. A alma na era da segunda revolução industrial. Tradução de Ciro Marcondes Filho. Disponível em:

www.eca.usp.br/nucleos/filocom/traducoes.html

${ }^{23}$ Mann, Klaus. Mephisto. São Paulo: Estação Liberdade, 2000. 
Nada tenho.

Nada me pode ser tirado.

Eu sou o ex-estranho,

O que veio sem ser chamado

$E$, gato, se foi sem fazer nenhum ruído.

Este livro de poemas, que ia se chama $O$ ex-estranho, expressa, na maior parte de seus poemas, uma vivência de despaisamento, o desconforto do not-belonging, o malestar do fora-de-foco, os mais modernos dos sentimentos. Nisso, cifra-se, talvez, sua única modernidade. Paulo Leminski ${ }^{1}$

O fato é que a vida sucumbe a uma atração estranha. Jean Baudrillard ${ }^{2}$

Billy licked his lips, thought a while, inquired at last: -Why me?

-That is a very Earthling question to ask, $M r$.

Pilgrim. Why you? Why us for that matter? Why anything?

-Because this moment simply is. Have you ever seen bugs trapped in amber?

-Yes"

Billy, in fact, had a paperweight in his office which was a blob of polished amber with three ladybugs embedded in it.

-Well, here we are, Mr. Pilgrim, trapped in the amber of this moment. There is no why.

Kurt Vonnegut ${ }^{3}$ 
A questão que aqui surge é acerca das características inapreensíveis e, por isso mesmo, sedutoras do discurso virtual em tempo real. A contingência é a de jamais poder se desmascarar totalmente o interlocutor, tocá-lo, tê-lo. A ordem é a da fantasia, a estratégia é a do engodo e o meio, o da invenção mentirosa. Essa condição traga o usuário para um looping de tentativas, todas elas frustradas, de encontrar a instância última onde os significados da verborragia dos chats se dão. Tudo em vão. Só se empreende essa viagem porque a condição de frases sem ancoragem explícita em um contexto, em um real, não é dada. A perturbação da ausência de materialidade é, paradoxalmente, a maldição de sua sedução.

É um objeto que bóia, que não afunda. Quem afunda sou eu, quando tento agarrá-lo. Sedução e tentativa de desvelamento, mas quando viram, já era tarde demais. Trata-se de enfrentar a sedução do objeto, tratase de desafiar a sedução.

É então como um sistema ou esquema ambulante, onde nos movemos na cena, ela própria puro movimento. Os deslocamentos podem até ser dedutivos, indutivos ou abdutivos, como quer a semiologia. Mas antes de todo o ferramental da cognição operar, o objeto já nos operou. Cognição é sempre resposta, e com atraso. Antes dela, a infecção do objeto até então estranho. Ou, como anotou Baudrillard, a sedução do objeto traiçoeiro ${ }^{4}$.

É que mesmo antes de ligar o computador eu já fui operado, infectado. Se a sedução começa bem antes, no negrume que vira luz, é porque já houve antes alguma comunicação. A comunicação, há que se temer, é anterior à própria significação. Esse sujeito e este objeto já se conhecem, estão apenas brincando em campos de centeio que já pisaram previamente. Jogos de compreensão, sedução e interpenetração. É aqui que a palavra entra. Ela não é nem criadora nem ordenadora do sentido. É um hospedeiro, temporário, que nos recebe e nos mostra as salas.

E as palavras passeiam, oscilando e permutando seus significantes num inesgotável jogo de sentido e não-sentido. Mas não são como vítimas. Philip K. Dick, escritor visionário, assina em seu 'Lê bal des schizos': Leva-me para teu quarto e possui-me. Há no teu vocabulário um não-sei-quê de indefinível que deixa a desejar. ${ }^{5}$ Seriam então os algozes? O trecho citado engana: não é nem a palavra nem o corpo, mas o que lhe está envolto: o movimento. É uma encenação que opera como combustível para o desejo de querer tocar, pegar na carne do mundo. Toque que não quer encontrar a carne, mas apalpar o próprio movimento que dissolve o corpo. Lembrar das silhuetas, da sua textura invisível e da vontade de segurá$1 a^{6}$. 
O mecanismo de sedução que esse medium emprega faz com que o encantamento, o charme irradiante das potencias imaginativas se organizem e dêem forma ao virtual, àquilo que existia apenas enquanto potência, em contraposição ao atual, àquilo que já existe. Trata-se, assim, de uma máquina de operar as potencias do virtual não atualizado, convertendo-o em linhas de possibilidades, de sonhos, de imaginações e vislumbres. Meu nick é, essencialmente, não aquilo que desejo que seja, mas aquilo que o outro quer que seja imediatamente atualizado ${ }^{7}$.

Isso porque não há a possibilidade de efetuar a captura da imobilidade do outro. Se há uma dose excessiva de encanto nessas máquinas de virtualidade escrita, é porque a sedução identifica-se à idéia de liberdade, de ausência de parâmetros precisos e delimitadores. O outro, assim, surge solto, móvel, transitório, quase uma máquina nômade impossível de se pegar, de se apalpar: silhuetas. O plano de apreensão dessas personas não se dá pelo crivo impassível e objetivo da imagem fotográfica, corpórea, mas pelo império sensorial, dissolvido, instância que abole o rosto e o olhar. O nexo realista, próprio à dimensão do Real castrador, é abolido por meio de um chaveamento do virtual com a movimentação incessante dos agentes. Seu efeito mais imediato é a imersão característica do virtual: êxtase imagético.

Nada lhe pertence, exceto as aparências - todos os poderes lhe escapam, mas ela reverte todos os seus signos. Quem se pode lhe opor? O único verdadeiro desafio está aí, no domínio e na estratégia das aparências, contra o poder do ser e do real. De nada serve jogar ser contra ser, verdade contra verdade; eis aí a armadilha de uma subversão dos fundamentos, quando basta uma ligeira manipulação das aparências. ${ }^{8}$

Ninguém pode salvar um usuário depois do login. A retirada só pode ser feita por sua inversão, pelo logout. O tempo da imersão é inabalável, pois não lida com os códigos de referência que o existente dispõe. A prisão voluntária da tela é efeito de uma luminosidade a que os usuários se vêem reféns, produto da lógica singular e irretocável de uma fábrica de brilho, não coordenada ou organizada por centro algum. Houvesse uma ética, seria a dispersão; houvesse um plano imediatamente político, este estaria apartado, vítima de um mecanismo que lhe transforma em correia de transmissão para um complexo que o ultrapassa. Aqui, só a luminosidade sensorial da tela medeia qualquer experiência.

Por isso sedução, pois o agente que faz com que o jogo se mantenha é o brilho intermitente que os nicks carregam, destarte toda a virtual mediocridade que possam guardar. A fulgurância particular das letrinhas impressas no fósforo do monitor impregna o outro em plena luminosidade, invadindo seus poros, fazendo-o brilhar também. É aqui que o movimento acontece: não sendo possível localizar de qual fonte exatamente a luminescência proveio, todo o sistema é impregnado por um engendrar que faz produzir mais e mais luz. A sedução, assim, não é individual e personalizada, mas sistêmica. 
Sem se dar conta disso, se apaixonam pela luz que acreditam vir do outro. A luz é fulminante e então corre-se para seu foco que, é claro, está em permanente movimento. Mas ocorre das imaginações trabalhadeiras escolherem um dos spots e grudar nele: cibersexo.

Estimulam-se, polarizando e eletrizando a relação que agora está fechada, dual. São agora dois corpos virtualizados, numa corrente imaginativa em que ambos resumem o enigma de toda aquela geração de luz. Finalmente o brilho é localizado, e um agente imprime ao outro a vitalidade da produção de luminescência, colocando-o em movimento, transformando-o em fonte de luz. Não operaram a sedução, entretanto. Foram operados por ela.

Não que o cybersexo seja efetivamente sexo, é também sedução, jogo. A todo o momento os chats parecem sexo, sem o ser. Apesar de ser abundantemente pornográfico, nunca é sexo, carne. É, pois, sempre simulação do signo sexo. Um chat é uma máquina de conjugar termos, que se atomizam para depois se desmancharem, construção e desconstrução, reversão: tudo se apresenta na vertigem dessa reversão, dessa transubstancialização do sexo nos signos, que é o segredo de toda sedução ${ }^{9}$. Cada um de nós é convidado a se tornar um "sistema de jogos" miniaturizado, um microssistema apto a jogar, onde as fantasias individuais constituem os próprios elementos do esporte. Como nos RPGs ${ }^{10}$, de onde os chats aliás derivaram, a regra do jogo é definida, tão somente, pela imaginação fantasiosa.

Memphis: Ou eu estou ficando louco ou estou vendo uma ligação cada vez mais tênue entre os canais com o passar do tempo.

Battw: Tudo igual, tudo joguinho. Idem para os Blogs.

Memphis: Blog? Dá nojo só de pensar naquela hpzona gigante e compridona que não acaba nunca.

Battw: É, é muita letra demais. Quem é você mesmo?

Um jogo que se quer irrestrito, de gestos sensuais e ritualísticos. Se o rapaz que se apresenta como moça que se comporta como um senhor é estranho, isso o é porque a (des)substancialização do sexo em signos é inesperada, embora indefectível. O segredo é o do atrevimento, pois se aperceberam que essa palavra não é a da carne, é sim simulação sob o signo do sexo.

Jogo talvez seja uma designação demasiado genérica para uma atividade cuja natureza e finalidade, apesar de recreativa e diretamente ligada ao entretenimento, pode deixar escapar o feitio que aqui importa. Esse jogo não implica em regras que estabelecem um vencedor ou perdedor, nem qualquer competição física ou mental com participantes disputando entre si premiações ou o prazer mesmo de vencer. Jogo em seu aspecto lúdico, uma brincadeira espontânea que não implica nem sorte nem azar. Jogadores porque o usuário está implicado em um modo de jogar, de movimentar-se, de operar. Se houvesse uma luta, um combate, não seria entre dois adversários. Mas entre eu e eu mesmo. 
pickles: Tem tanta coisa depois disso aqui...

pickles: vcs são uns tolos.

pickles: Sonic...

Sonic: Sim?

pickles: faça a conta matemática...

pickles: divida seu dia em horas despertas e horas

de sono.

Sonic: hm.

Sonic: horas de sono: 9

pickles: agora veja...

pickles: Eu falo das horas despertas...

Sonic: horas acordado: 15

pickles: sabe o que ocorre aqui, no RC?

Sonic: o que acontece?

pickles: uma desgraçada inversão

Mmms: hummmmmmmmmmmmmmm

Sonic: que inversão?

Sonic: Pessoal, vocês entendem o problema da

pickles?

Sonic: algum de vocês?

pickles: nós crentes que passamos noite e madrugada boba de papo furado... Tudo idiotice.

Sonic: ahh

Sonic: to aproveitando antes de cortarem

pickles: A hora passada aqui é a hora acordada do

dia, Aiwass. Só que você não percebe isso.

pickles: calcule!

Mmms: vão te cortar?

Sonic: ahh

pickles: o que você fará amanhã?

Sonic: tipo...

Sonic: eu fico acordado até as 2 da tarde

pickles: ok, ok....

pickles: não quero mais falar...
Sonic: você quer me dizer que é viciada em

IRC é isto?

Sonic: é isto o tempo todo?

* pickles sabe que aqui é a terra da

abobrinha!

Sonic: tipo...

Sonic: é?

Mmms: todos aqui somos ventríloquos.

Sonic: é assim com todos e em qualquer lugar

Sonic: mesmo o DNA não sabe seu objetivo

Sonic: veja, eu me sinto tri estranho

Sonic: ninguém me conhece e mesmo assim

falam comigo

* Bejyn quase ri.

Sonic: eu conheci a Internet em 93

Sonic: mas a história da minha esquizofrenia

Sonic: vocês ouvem outra hora

$<$ Bejyn> sinopse autobiográfica?

Sonic: é

Sonic: ;)

* Bejyn quase ri.

Sonic: eu entrei na Internet em 93

Sonic: nós ficávamos $8,12,20$ horas

conectados no terminal de texto da

universidade

Sonic: baixando TEXTOS

Sonic: tem TUDO que eu quero na rede.

Bejyn: que vidinha maçante. :)

Sonic: nos conhecemos lá

Sonic: :))

Bejyn: segundo capítulo: "Minhas Amizades"

Sonic: eu lido com computadores desde 85

Sonic: estou acostumado

Por isso, retomar os sentidos de "manha" e "ludibrio" que o jogo também implica. Não pode haver regras rígidas na sedução identitária que eu traço para comigo mesmo. Antes disso, a traição à regra do meu jogo é a finalidade mesma do chat, onde se finge ser quem não se pode, não se quer, não vai. Trata-se de um jogo de ficção identitária, de memórias e falseamentos diversos, enganações e duras confissões trabalhadas nesse cru amalgama que é o bate-papo. Usa-se de fatos biográficos como ferramenta para a desconstrução de memórias pessoais, espécie de reescrita infiel que ficcionaliza a veracidade da memória, normalmente irrecusável. Perder ou ganhar implicaria em pôr fim a algo quando, aqui, apenas o refazer permanece.

A substituição do nome próprio, o uso de nicknames, é o ato primevo de uma traição: inequívoco sinal da renúncia à veracidade e ao cumprimento de uma história pessoal. História vira estória, e o real, fantasia. Podem até ser memórias, mas recusam tanto a verificação imediata do histórico pessoal quanto a liberdade artística da ficção. Seus usuários escrevem os anais de uma mentira coletiva, traindo permanentemente o contrato fundante das relações interpessoais, que é a fidelidade à verdade. Mas se esta é uma situação imediatamente dada, como podem ser mentirosos? Podem porque são falsos 
mentirosos, dizendo uma eventual verdade enquanto sugerem ser mentira. Mas há o momento em que deixam de mentir e deixam de saber o que é verdadeiro. Nestes instantes, os falsos mentirosos mentem de forma deliberada e exponencial. É o mágico instante em que o mentiroso se revela ao mesmo tempo falso e verdadeiro mentiroso ${ }^{11}$.

São assim falsas mentiras; verdadeiras e sinceras ficções. A condição paradoxal de um discurso que nem sequer fia-se em seu agente estruturador, o narrador. Decidiu-se aí que já não é possível estipular qualquer parâmetro para a existência ficcional e construída. Pois não se trata de tomar a vida como ficção, mas de encarar a existência como indelevelmente condenada à ficção ${ }^{12}$.

Isso quer dizer apenas que é vão procurar uma unidade apenas verdadeira ou apenas falsa nestes diálogos, pois sua energia consiste na fusão das duas dimensões, na produção de uma realidade imaginada. O diálogo pode criar o inesperado quando não se restringe ao ordinário, quando se permite ser uma meta-conversa. Para tanto, simplesmente ignoraram o que fazem ali. Quando os usuários escapam das questões de praxe, tais como "idade, cidade, sexo", arriscam uma inversão no sentido préfixado da interação. É uma investida comunicacional.

Esses diálogos lidam com uma forma anômala de preenchimento de sentido ${ }^{13}$. Existe uma aceitação implícita de certas táticas de interação, dentre elas, a exibição, cuja mais perfeita tradução encontra-se na correlação entre mostrar e esconder. Essa díade, elemento capital da mentira e da sedução, não se dá entre momentos opostos, nem sequer separados. Ambas as séries se fundem, se encadeiam, sem jamais se saber com precisão em qual dos lados o usuário está. São seqüências de emulações em que é impossível detectar qual extremo se está operando: mentindo ou entregando-se completamente.

À imersão na tela, me abismo. Quando me abismo a tela também se abisma - espaço de fantasia, intermezzo de fluxo, território de devir ou máquina de subjetivação. Nele, a fantasia vai construindo seu enredo particular enquanto a imaginação roteiriza a presença imagética dos meus parceiros, meu Outro nó, em rede. É a imaginação pura que seleciona os participantes neste casting de personagens imaginários. Nenhum roteiro, nenhuma obra tem fim no maquinismo do abismo-monitor. A máquina que fabrica imaginação tem sua linha de montagem dinamizada pelo complexo de fantasias e desejos dos participantes, engendrando um sistema em algo similar ao industrial, produzindo círculos imaginários, concêntricos e espiralados: é o próprio forjar dos imperceptíveis elementos chamados "cultura". 


\section{NOTAS}

${ }^{1}$ Leminski, Paulo. O ex-estranho. São Paulo: Iluminuras, 2001.
${ }^{2}$ Baudrillard, Jean. A Transparência do Mal: ensaio sobre os fenômenos extremos. Campinas: Papirus, 2003, (p.167).

${ }^{3}$ Vonnegut, Kurt. Slaughterhouse-Five or The Children's Crusade. A Duty-Dance with Death. New York: Delta Publishing, 1999. Assim entendeu a versão portuguesa: “"- Bem vindo a bordo, Mr. Pilgrim' - disse o alto-falante. - 'Quer fazer alguma pergunta'? Billy lambeu os lábios, pensou um bocado, e inquiriu por fim: - 'Por quê eu?' - 'Isso é uma pergunta muito terráquea, Mr. Pilgrim. Por quê o senhor? Por quê nós, já agora? Por quê o que quer que seja? Porque este momento existe simplesmente. Já alguma vez viu insetos encerrados em âmbar?' - 'Sim'. De fato Billy tinha um pesa-papéis no consultório que era um globo de âmbar polido com três insetos do sexo feminino embebidos nele. - 'Bom, cá estamos nós, Mr. Pilgrim, presos no âmbar deste momento. Não há porquê nenhum'". Vonnegut, Kurt. Matadouro Cinco ou A Cruzada das Crianças. Lisboa: Caminho, 1990. (p.76-77)

4 "O algoritmo e a ciência exata falam das coisas, só supõem no seu interlocutor ideal o conhecimento das definições, não procuram seduzi-lo, não esperam dele nenhuma cumplicidade, e, em princípio, o conduzem como que pela mão do que ele sabe ao que deve aprender, sem que tenha de deixar a evidência interior pela sedução da palavra." Merleau-Ponty, Maurice. $A$ prosa do mundo. Rio de Janeiro: Bloch, 1974. (p.139).

${ }^{5}$ Baudrillard, Jean. Da Sedução. Campinas: Papirus, 1992. (p.36).

${ }^{6}$ Tal como na interessante citação, aqui evocada do filme Estorvo, de Ruy Guerra, baseado no livro de Chico Buarque: "Não é um corpo assim dissimulado que as mãos tem maior desejo de tocar? Não para encontrar a carne, mas para apalpar o próprio movimento". Estorvo, (Idem). Direção: Ruy Guerra. Brasil / Cuba / Portugal: Europa Filmes, 2000. Color, son., 35mm, 95min/Brasil, 96min/França. Baseado no romance de Chico Buarque de Hollanda. Roteiro: Ruy Guerra. O filme foi lançado no Brasil em DVD pela Europa Filmes.

7 "O que seduz não é este ou aquele gesto feminino mas o que é para vós. Ele é sedutor por ser seduzido, por conseguinte o ser-seduzido é que é sedutor. Em outros termos, a pessoa sedutora é aquela na qual o ser seduzido reencontra-se. A pessoa seduzida encontra no outro o que a seduz, o único objeto de sua fascinação, a saber, seu próprio ser todo feito de encanto e sedução, a imagem amável de si mesmo.” Baudrillard, Jean. Da Sedução. Campinas: Papirus, 1992. (p.78).

${ }^{8}$ Idem. (p.15).

${ }^{9}$ Ibidem, (p.18).

${ }^{10}$ RPG (Role Playing Game) é uma espécie de jogo onde um ou mais jogadores personificam um papel a desempenhar e atuam em conformidade com ele em um ambiente imaginado ou em realidade virtual. Embora tenha surgido a partir de tabuleiros e livros, foi rapidamente transposto para a Internet nos afamados MUDs e MOOs. Sobre essas misturas de batepapo com RPG: "Tenho a impressão de que os trabalhos mais provocativos estão acontecendo nas tecnologias vernáculares de games, MOOs e, mais especificamente, os textos cinéticos de poesia eletrônica nos quais a linguagem, enfim, encontra o seu elemento natural em movimento, não em uma janela, mas como uma janela, não como uma superfície única, mas como uma experiência auditiva, visual e proprioceptiva de superfícies sucessivas”. Joyce, Michael. Formas de futuro. In: Leão, Lúcia (org). Interlab - Labirintos do pensamento contemporâneo. São Paulo: Iluminuras, 2002. (p.54).

11 "A mentira seria nesse sentido um ajuste muito parecido com o que é exercido na elaboração e manutenção das personas midiáticas. Sabemos que essas personas não são exatamente como se apresentam, mas as aceitamos mesmo assim, e até gostamos delas por causa disso. Exatamente porque não são como as outras pessoas que conhecemos." Jupy Jr., Edmar de Araújo. Chats: comunicação e sociedade. Revista 404nOtF0und Ano 4, vol. 1, no 36, ISSN 1676-2916, 02/2004. Disponível em: http://www.facom.ufba.br/ciberpesquisa/404nOtF0und; Ciberlegenda, No11, 2003: http://www.uff.br/mestcii/jupy2.htm

12 "Os consumidores vivem vidas roteirizadas, com máquinas criadoras da realidade antecipando cada um de seus movimentos. O fenômeno é tão forte que cada indivíduo é constituído na realidade por dois corpos: um real e outro fictício (moldado pela informação recebida). Nessa nova estrutura, como será possível alterar os feixes de imagens que falseiam a realidade? Será essa 'realidade' desejável? Os novos revolucionários poderão ser, então, os 'imaginadores', os que fazem ficção assumindo que a fazem - gente que recupera o prazer silencioso de todo artesanato, combinado ao prazer estimulante do jogo?" Pinto, Regina Célia. Olhar Axolotes. Baseado em Axolote de Julio Cortazar e A dúvida de Flusser - filosofia e literatura, de Gustavo Bernardo. 2004. Disponível em: http://www.arteonline.arq.br/viewing_axolotls/\#

${ }^{13}$ Ver a este respeito o capítulo Linguagem carne cor-de-plástico. 
Não quero realismo. Quero mágica! Sim, mágica. Tento dar isso às pessoas. Sei que deturpo as coisas!

Digo o que deveria ser verdade.

Se isso é pecado, castigue-me! Blanche, de Um bonde chamado Desejo ${ }^{1}$

Conversei com muitas mulheres, mas depois omiti o que elas me disseram. Mesmo assim, é tudo real, embora não realista - real na medida em que essa mulher poderia existir de fato, coisa que me parece muito mais importante que o realismo.

Peter Handke ${ }^{2}$

<Martha> Você é, sem dúvida alguma, a pessoa mais surpreendente que já conheci.

Você me excita tanto que tenho medo! < Guy> Está tudo na sua cabeça, querida.

Robin Hamman ${ }^{3}$

A ilusão está fundada no mais profundo da inteligência, e propriamente falando, ela é indispensável, não pode ser dissipada, mas somente recalcada.

Henry Bergson ${ }^{4}$

A questão de onde termina a realidade e onde começa a aparência está colocada de forma errada: isso porque o rádio, a imagem televisiva e o consumo de fantasmas são em si realidades sociais de tal massividade, que podem aceitar a luta com as outras demais realidades atuais, afirmando que elas mesmas determinam "o que é real”, "o que de fato se passou”.

Günther Anders ${ }^{5}$

E se você olhar longamente para o abismo, o abismo também olha para dentro de você. Friedrich Nietzsche ${ }^{6}$ 
Um dos temas centrais nos debates sobre a comunicação mediada pelo computador é como funciona a percepção e representação do outro. Willian Gibson, na sua bíblia do ciberespaço, já dizia que a condição para que o ciberespaço exista é haver pessoas que se permitam acreditar nele ${ }^{7}$. Da etnografia à sociologia de Goffman abundam estudos interessados em compreender como essa mediação sem imagens ocorre ${ }^{8}$. Que diálogos são estes, perguntam.

Dentro de uma perspectiva próxima a Goffman ${ }^{9}$, podemos dizer que se trata, naturalmente, de um diálogo extremamente peculiar. O domínio que a escrita textual no ciberespaço possibilita se estrutura de forma diferente que na vida real, no cara-a-cara. Em oposição às perguntas, colocações e "expectativas" das conversas cotidianas, que exigem de Alter e de Ego uma continuidade lógica entre os diálogos, os chats instauram na conversa uma contingência flutuante e mais ampla. A conversa pode a qualquer momento ser reiniciada por um assunto ou tópico não presente no assunto atual. O jogo dos enunciados, assim, não sofre a coerção da continuidade que a interação real impõem. São abertas as portas da imaginação, os diálogos podem lembrar delírios, já que cada um, escrevendo o que lhe é de interesse, só compreende a intervenção de Alter dentro das preocupações individuais, particulares ao seu discurso. Essa esquizofrenia de diálogos narcísicos também é, aparentemente, uma característica sistêmica que o ambiente proporciona ao medium.

Rosanne Stone, no seu estudo sobre os serviços de disque-sexo, trabalha com a usual dicotomia que os meios eletrônicos instauram: a pequena banda de informações disponível entre os interagentes. Tomando a conversação real, cara-a-cara, como modelo, pode-se dizer que a oferta de informação é brutal: voz, imagem, postura, expressão corporal, toque, cheiro, etc. Assim, os canais de disque-sexo por telefone contam com a falta de informação visual que deverá ser preenchida pela imaginação do cliente. Segundo a autora, ainda que permaneça um bom contingente de informação no discurso oral, como inflexões, pausas, tom de voz e ritmo da fala, a menor presença de informação é o que fomenta a interpretação sobre o que se passa. Assim, por trás das palavras quentes dos serviços de sexo por voz pode haver uma pacata dona de casa pintando suas unhas ou preparando o jantar; nada prova o contrário. Só funciona porque a fantasia estabelece meios de tornar real ${ }^{10}$.

Lestat: Eu te conheço em qual faceta?

Verga: Você não me conhece.

Verga Você, aliás, não faz a menor idéia de que estradas tortuosas e labirintos sem fim tive que enfrentar para te descobrir aqui nesse canal!

Lestat: Sei, agora estou te vendo.

Verga: Não, tudo que você vê, agora, é um monitor.

Niklas Luhmann, sociólogo que desenha uma híbrida teoria dos sistemas, entende todo o complexo de informações que a comunicação pessoa-a-pessoa proporciona dentro da dinâmica comunicacional de 
autocontrole dos sistemas ${ }^{11}$. Assim, sugere uma inquietante concepção de que é fundamentalmente a palavra escrita, ao apartar os agentes que se comunicam, que instaura a ordem da imaginação:

Esta espécie de autocontrole da aceitação/recusa na comunicação mediante a presença corporal rompe-se com o surgimento da linguagem escrita. (...) Como a comunicação escrita deixa ilhado tanto quem escreve como quem lê, cria-se um texto que já não pode ser controlado pela presença da interação. Agora é o texto quem seduz, e não mais a presença. A carta, por exemplo, possibilita que a relação amorosa possa se manter secretamente, produzindo um efeito sedutor. (...) A sedução se dá pela própria carta, ou seja, pelo que a mulher lê e interpreta sozinha, solitária e deixada à sua própria imaginação. Não se utiliza, em primeiro lugar, os meios da presença física: olhares, gestos, suspiros, retórica; a carta faz com que a mulher se seduza a si mesma porque ao ler e escrever ela está sozinha, exposta a sua própria imaginação e não pode se opor a ela. ${ }^{12}$

Robin Hamman, em seu bastante citado artigo sobre a Fantasia na comunicação on-line ${ }^{13}$, narra suas desventuras ao fazer a transferência de seus amigos virtuais para a vida real. Conta que dentro de suas inúmeras conexões acabou por conhecer Michelle, com quem travou uma relação agradável. Apesar de serem quase vizinhos, conversam meses por chat sem se ver ou se falar cara-a-cara. Trocam tantas emoções e compartilham tantos momentos que Hamman se apaixona por sua parceira virtual. $\mathrm{O}$ relacionamento permanece maravilhoso até que o autor, na fila do cinema, ouve alguém ser chamado pelo apelido virtual de sua parceira. Ainda que fosse uma mulher bonita, Hamman diz que a imagem montada da mulher por quem se apaixonou se esvaiu. Conversam então brevemente sobre o relacionamento para descobrir que nada tinham em comum. Banho de realidade? Hamman continuou teclando e teclado com parceiras virtuais.

Certa noite, enquanto procurava material para sua pesquisa, conversou com uma mulher por quase uma hora. O processo de imaginação começou e Hamman se maravilhou com as (auto)descrições do interlocutor. Tiveram momentos de ternura e tudo caminhava belo, azul, e quente quando o computador de Hamman trava e ele tem que desligá-lo. Descontente diante da possibilidade de nunca mais ver sua interessante nova amiga, envia-lhe um e-mail fazendo contato. Excitado e maravilhado, Hamman decide reler a conversa que tiveram e constata que tudo que sabia sobre a garota era sua idade, nome, cidade, preferência musical e trabalho. O que Hamman se pergunta é o quê possibilita sentimentos de afeição, identificação e proximidade quando tudo que sabiam um do outro eram detalhes básicos. Isso tudo, é claro, supondo que se tratasse mesmo de uma mulher.

Hamman muda de técnica e decide não participar das discussões. A tentativa do autor de assistir a conversação cibercultural dos chats sem participar resulta numa interessante impressão: quando apenas parou para assistir os usuários interagindo, teclando e enviando frases intermitentemente, percebeu que muito do que ali era digitado parecia totalmente desprovido de sentido, parecendo muito pouco com 
diálogos normais. Hammam poderia ter ido adiante e explorado a faceta multilogue dos bate-papos, refletindo sobre que tipo de conversa se dá em um ambiente sem contato direto. No entanto, quando diz que em certo ponto não conseguia mais distinguir quem falava com quem ou perceber para onde caminhava o sentido dentro das conversas inextricáveis, ele nos dá uma interessante dica de que o chat não é um canal de conversa. Está um pouco além ou aquém disso ${ }^{14}$.

Session Start: Mon Oct 20 03:49:30 2003

Etraf: Hal seu idiota. Por que você perde tanto do seu tempo aqui?

Etraf: Você não gosta das pessoas daqui e fica noites e mais noites, a troco de quê?

HAL: Etraf, eu não acredito nessas letrinhas. Apenas sigo meu monitor. Aonde você vê pessoas?

Etraf: Será que não entende que apesar de não vê-las você ainda conversa com pessoas aqui?

HAL: Claro que converso. Gosto de pensar que sim e que, em parte, elas me sentem e entendem.

Etraf: Você tem é um belo e grande problema mental

HAL: Etraf, a maior parte do que dizemos não surte efeito algum, sabia?

HAL: Você fica entrando aqui para encontrar gente que não existe, como se esperasse a revelação.

Etraf: Entro aqui pq tenho AMIGOS, HAL. Porque tenho a capacidade maravilhosa de conquistá-los.

HAL: É? E como eles são? São morenos e saudáveis ou se parecem com o Mario Bros.?

HAL: Etraf, não são exatamente amigos. São amigos mas são imaginários, entende?

Etraf: Larga de ser burro. Você está ligado na minha psique, se é real pra mim também é pra você.

HAL: Antes fosse, Etrof. Nós não nos entendemos tão bem.

Etraf: Se eu não sou real, como você reage as minhas ações?

HAL: A maior parte do tempo nós só nos iludimos que os outros entendem tudo perfeitamente.

HAL: Claro que você é real. O problema não está entre você e eu, mas entre nós.

Etraf: Nós dois sabemos que nos entendemos perfeitamente.

HAL: Isso tudo porque a sua frase é errônea: "o que é real pra mim é real pra você". É exatamente o contrário. O que é real pra você, pode não ser pra mim. Vice-versa.

HAL: As referências estão sempre rodando. Mas nós precisamos achar que elas estão estáticas para podermos conversar pragmaticamente.

Etraf: Sabe aonde você enfia essa tua perspectiva, HAL?

O lugar preciso desse tipo de diálogo é o espaço virtual da subjetividade. Isso porque não é um diálogo tal como entendemos, mas uma série de introjeções que o próprio agente cria e recria. $\mathrm{O}$ efeito mais surpreendente que a dispersão das tecnologias informacionais criam sobre o Ego é a profusão indiscriminada de imagens que não se coadunam com a identidade moderna: centralizada, una e coerente. Essa fratura da unidade gera um sujeito esquizofrênico não na acepção clínico-freudiana, mas deleuzeana, qual seja: do devir e das máquinas desejantes. É uma prática de abertura e processamento sem triagem ou filtro, que não se coordena por diretrizes conceituais mas por fluxos de sentido, muitas vezes contraditórios.

Vemos a fantasia como motor fundamental para o andamento do jogo midiático porque é a formação do indivíduo que demanda essa virtualidade. Espécie de identidade que se constrói e se desconstrói narrativamente, jogo de aliterações, montagens, bricolagens. Isso porque a subjetividade não é um dado de fato, imediato: é construção que se faz através dos recursos culturais disponíveis, que o indivíduo conduz em coordenação com suas relações sociais. A relação entre os media e a sociedade não é de determinação, mas de sincronicidade: na TV proliferam estilos de vida, mas eles só viram personagens quando formam uma identidade coerente com as modalidades de ser da contemporaneidade. 
Parafraseando Tomás de Aquino, não há nada que o objeto reflita que não esteja anteriormente em mim, ainda que embrionariamente. Recolho partes e luminescências do objeto como quem colhe flores no jardim. No mеи jardim. Como Bergson que, afirmando que tudo o que a percepção toma do objeto só o faz por uma questão de fim, no instante mesmo do assunto comum ${ }^{15}$. Quando converso e me coloco ante meu interlocutor, projeto a contingência de virtualidades que me constituem e que processo ininterruptamente neste arcabouço de material fervente que chamamos subjetividade. No ato de comunicar engano-me conscientemente com o que o outro diz ou como se apresenta. Ato de autoludibriar que expande minha percepção. Se fosse só o visível, seríamos objeto. É preciso percepcionar o que não existe, ainda. Fantasiar: a visão guardiã tem que descansar, pois o que nós não vemos, sentimos.

Desejo, na perspectiva deleuziana, é o que nos faz estabelecer conexões com coisas. Reais ou Ideais, pouco importa, é o investimento feito pelo desejo que confere à materialidade, realidade. Da mesma forma, a concepção de Desejo em Lacan é capital e não se desvincula de sua teoria da fantasia. Desejar não existe sem fantasiar: o movimento de imaginar algo ou alguém é a criação de cenários, figurinos e ambientes onde a vontade será satisfeita. Fantasia, para Lacan, é um querer que pode explicar muito sobre o Desejo, pois quando fantasiamos cenas de amor e paixão não imaginamos apenas o objeto de desejo, mas todo um cenário onde finalmente o ato deve se consumar.

Desejo e fantasia, assim entendidos, não são exatamente anteriores e hierarquizados. Obedecem antes a uma sincronia de realização que dentro da concepção lacaniana é um deslocadamento constante: aparecem amarrados, entremeados. Ou seja, não se trata de Desejo e Fantasia como um processo de imaginar e realizar, pois desde Freud o desejo não tem um objeto natural: não há objeto do desejo. Como Lacan explicita no afamado quinto seminário (As Formações do Desejo) ${ }^{16}$, este é caracterizado por uma metonímia que não tem fim, espécie de movimento de um objeto para outro sem jamais se deter definitivamente. Desejo é o desejo do Outro - aforismo primeiro da catequese lacaniana, não implica apenas que o inconsciente é estruturado pela linguagem, ou que Desejo é desejo de ser desejado, mas sobretudo que deseja-se perpetuamente o que é outro, uma outra coisa, diferente: o deslocamento do desejo sempre procura o objeto que não está.

Assim, não se sabe o que se deseja. Eu desejo sem saber exatamente o que - é isso que eu desejo. Procuramos através da miríade mundana de objetos infinitos aquele que finalmente preencherá a falta. É precisamente neste sistema de desejo que a fantasia joga um papel importante. Sua primeira função, naturalmente, é oferecer um campo onde se possa desejar. Não se trata apenas de imaginar satisfações através do objeto, mas dar forma e existência ao desejo. A fantasia, assim, funciona como estruturante e alimentador do desejo: produz realidade. 
Session Start: Thu Feb 19 05:40:28 1998

PVT entre os usuários velho_mogly e Ritalina Ritalina: eu disse sim... e repito pra quem quiser ouvir: Ritalina acha que ama o Kil! Ritalina: se você não acredita, não posso fazer nada.

velho_mogly: Não mesmo. Mas não me odeie por isso. Só estou TENTANDO não cair em mais uma dessas armadilhas.

Ritalina: Foi fenomênico o que senti hoje quando falei com ele... isso é sério.

Enquanto isso, no \# Castle_of_elysium

Ritalina: Kill|IIIIIIIIIII!!! I love you... e é sério.

Kil jaeden: sei, sei.. : *

Ritalina:_12:::---=_4( $\left(^{-\circ^{\prime}-}\right) \_12---{ }_{-} 1$

Presente pra Kil jaeden

Ritalina: quando alguém se sente

inesperadamente feliz quando encontra

alguém... deve ser alguma forma de amor...

ou será que não?

Kil jaeden: Tomara

velho mogly: Putz

Kil jaeden: Ritalinaaaaaaaaaaa : ${ }^{* * * *}$

velho_mogly: vou nukar os dois se

continuarem com essa frescura

Ritalina: : ${ }^{* * * * *}$

Ritalina: poxa, velho... :|

Corte para:

Kil jaeden:

* Ritalina saudades: ${ }^{* * * * * * * *}$

velho_mogly: continuem

Ritalina: Kil... o velho_mogly pensa que é brincadeira eu ter confessado que amo você.

Kil jaeden: tsc tsc tsc... esse velho_mogly é um asno.

velho_mogly: * Ritalina só fala sério de coisas sérias.

velho_mogly: velho_mogly: como pode?

velho_mogly: velho_mogly: ah, saquei.

velho_mogly: Ritalina: o que você tem contra eu me sentir repentinamente arrebatada por um sentimento?

velho_mogly: velho_mogly: ai ai ai.

velho_mogly: Ritalina: não é não.

velho_mogly: Ritalina: é sério.

velho_mogly: velho_mogly: ok, ok.

velho_mogly: Ritalina: eu sinto isso

velho_mogly: opa, foi mal.

Ritalina: estava dizendo pra ele que é sério... foi bonito.

* Ritalina não tem duas caras nem duas palavras!

Ritalina: qualquer coisa que eu pronuncie é público.

Ritalina: não sei que feitiço o Kil usou hoje...

* Ritalina vítima de encantamento ou bruxaria.
O canal Castle_of_elysium contou certa vez um episódio exemplar. A usuária Ritalina e o usuário Kiljjaeden caem de amores um pelo outro, para desespero do usuário velho_mogly, que tudo acompanhou e pouco entendeu.

Seguem-se beijos, abraços e carinhos diversos no canal. Uma rotina em que um dos usuários entra e espera o outro, e quando este chega o canal é infestado por manifestações dos amantes virtuais. O usuário velho_mogly, que acompanhou o processo intermediando os amantes, é cético à relação toda. Ele chega a transcrever no canal a conversa que havia tido com a Ritalina (quadro ao lado).

A situação se mantém regularmente, entrecortada por juras de amor, algumas eternas, outras nem tanto, durante um período de três ou quatro meses. Rememoram quando primeiro começaram a digitar, os canais e amigos em comum e outros assuntos particulares ao chat. Algumas semanas depois, desapareceram para retomar o IRC com novos nicks. Vida nova, amante virtual novo.

Session Start: Fri Dec 19 01:22:24 1997

||PIN||: Olá Sr. Unha, eu sou a Odete Roitman. ||PIN||: Você não acredita??

Unha: Droga! É sempre assim! As pessoas me confundem com palavras e depois me dizem que eu preciso de ajuda. Aí eu vou falar isso com alguém, desabafar e as pessoas com eçam a rir. Isso quando não pegam no meu pênis! Eu não agüento mais.

Session Close: Fri Dec 19 01:26:07 1997

Germa: Você é da onde, Asterix?

Asterix: Do castelo, claro.

Germa: Asterix, sério, você é da onde?

* Asterix é filho da rainha, mora no Castelo.

Asterix : Pô germano, que diferença faz!

*** Asterix is now known as Kil jaeden

Kil jaeden: Lembrou de mim agora?

Germa: Hum! Ah, claro, então é você.

Kil jaeden: ;)

Germa: Mas na realidade, você é da onde? 
Session Start: Sat Apr 05 04:08:03 2003

Januer: Você me lembra muito um amigo meu, o

Ritchiee. Ele fala como você, sabe o mesmo que você, se você não é ele estamos diante de uma enorme coincidência.

Kinda: Então estamos diante de uma enorme coincidência. Porque eu jamais seria idiota a ponto de me deixar chamar por "Ritchiee".

Januer: Até mesmo o fato de ligar uma frase a uma

tese inteira só para descomprová-la

Kinda: Não entendi.

Januer: Acontece que nomes não se escolhem, por isso não importa se você é idiota ou não.

Januer: Não. Eu disse uma coisa e você deu um nome e disse que essa tese já era. Mas nem quis saber se o que eu disse se conecta completamente com a tese ou não, Ritchiee.

Kinda: Januer, Januer, é claro que se conecta.

Repense sua pergunta e diga-me se tem relação ou não. Olha, eu não sou esse tal de Ritchiee.

Januer: E se quiser falar alguma coisa séria, não esse cata piolhos que você faz em tudo que eu digo, não precisa fingir ser outra pessoa.

Kinda: Januer, eu não sou o Rithciee, tudo bem? Januer: Ok. Então digamos que eu estou cansado de aturar a mesma conversa de vocês.

Kinda: Januer, antes que eu te mande pro inferno, responda-me: qual é o problema?

Januer: É essa sua necessidade que você vai ter que resolver com um profissional

Kinda: Tá bom. Ponto pra você. Vamos voltar a falar daquelas besteiras de antes.

Januer: Gosto não se discute.

Januer: Você mora em Brasília

Kinda: Tsc tsc tsc.

Kinda: Eu moro no Rio, não sou o Ritchiee.

Kinda: Vocês moram em Brasília, Januer e Ritchiee? Januer: que pena. E como sabe que ele mora em Brasília? É adivinho?

Kinda: Porque você disse, Januer.

Kinda: Januer, você está pirando, companheiro?

Januer: Não, eu não disse.

Kinda: Olha o que você escreveu: Januer: você mora em Brasília.

Januer: Foi uma pergunta. Você ligou as coisas muito bem. Mas tudo bem, esse tipo de coisa acontece o tempo todo.

Kinda: Uma pergunta sem ponto de interrogação?

Kinda: Januer, meu caro, você está imaginando

coisas e pessoas.

Session Close: Sat Apr 05 05:08:03 2003
Logging: A usuária de nick Dengosa entra no canal e abre um PVT com o nick Lucipher. Começa a conversa convicta que está falando com alguém maravilhoso, especial, certa de partilharem afinidades raras. "Somos intuitivos, posso ver. Aposto que sabe dizer como sou" - diz ela. Não contente com rodeios mil, tentativas do usuário de se desvencilhar, cobra uma descrição que, acredita, será o retrato perfeito dela mesma. "Por favor, quero ver se consigo transmitir o que sou de verdade. Até por que isso é importante. Afinal, estou em um canal de conversa". O usuário traça um perfil genérico, positivo e inexato, típico de horóscopo folhetinesco. Consegue o que tanto queria: "Você vive cheio de pessoas, mas elas não te entendem, é sensível, muito amável, mas aventureira. Tem compaixão e sofre por conta disso. Acredita no ser humano não se dando jamais por desiludida, e por isso sempre se ilude". O resultado da descrição do usuário infernal é impressionante, pois transforma em realidade não só uma relação que nunca existiu, que não vai existir: faz do emissário do diabo, um mágico, uma pessoa maravilhosa. Ela chega mesmo a dizer: "Mais que um mago. Você é um feiticeiro bom. Posso ver isso nos seus olhos". Ou seja, no final das contas, até Lúcifer vira Gabriel.

Quem poderia dizer que esta usuária foi ludibriada por seu interlocutor? Ela já se apresenta com uma série de convicções que não parecem dispostas a lhe abandonar a cabeça. Chama atenção não só o fato dessa necessidade ter invertido o significado dos nicks, mas a certeza absoluta de conversar com "uma pessoa maravilhosa". 
Hame: Acredite, Guest85, pode haver mais que letrinhas em uma comunicação de IRC.

Hame: Claro que também não é preciso embarcar de corpo e alma numa coisa dessas.

Hame: É preciso sensibilidade para perceber a intenção real.

Guest85: E sei que da mesma forma que não são só letrinhas, pode ser muito importante.

Pombo: Há uma comunicação... isso eu concordo com o Hame.

Guest85: Letrinhas podem se tornar sentimentos, representá-los. E podem ser apenas letras.

Piano: E aqui, o que elas são?

Hame: São seus pensamentos tomando forma.

Guest85: Há muitas dessas letrinhas que me fazem chorar, gostar, e representam muito para mim. Guest85: São pessoas, de fato.

Piano: Você se comunica com uma pessoa sem a ver?

Guest85: Estou aprendendo a lidar com isso. Ter amigos que não passam de letrinhas.

Guest85: E letrinhas que são muito para mim.

Hame: Por que não? livros fazem isso há séculos.

Hame: Cartas também o fazem.

Piano: Você não conversa com o autor de um livro. Ele diz e você escuta. É diferente.

Guest85: Bem, falo de letrinhas representarem alguém, ser vivo.

Pombo: Justamente por PARECER não haver as pessoas, qu'eu creio que as pessoas se abram mais. Já vi pessoas contarem intimidades aqui na net (de todos os gêneros) que jamais contariam

pessoalmente. Coisas que nem meus(inhas) melhores amigos(as) e irmãs contariam pessoalmente.

Guest85: Mas pode ser favorável ser só a mensagem, a atenção é toda no ponto central, a palavra.

Hame: Porque existe muito crossover na comunicação via Net, mas ainda assim pode-se separar o que é útil.

Hame: Sou realista nesse ponto... não me deixo envolver pelo primeiro aceno que recebo, e sei discernir muito bem quando a intenção é perturbar.

Piano: Acho que há muito mais idealização do que se pode achar numa primeira vista.

Piano: A imaginação joga um papel forte por aqui.

Hame: Sempre joga, mesmo 'ao vivo'.

Hame: É claro que você pode estar em um PVT com um caminhoneiro brutamontes que fantasia ser uma menininha de 16 anos. :)

Gardenia: Imaginar não é bom...

Gardenia: Quando você vai conhecer a inevitável verdade, por mais que seja boa, sempre será

frustrante... porque não há o que possa competir com a imaginação, ela é perfeita.

Gardenia: Tá, mas tem coisa mais pejorativa do que "amigo virtual"? Soa, no mínimo, diminutivo.

Hame: Sem dúvida, é um termo semanticamente correto e que pode ser pragmaticamente errado.

Gardenia: E sentimentalmente confuso.

Hame: Não se espera relacionamento afetivo na Internet... o erro é fazê-lo.

Pateticamente_sentimental: Não é erro, é uma necessidade. O erro está exclusivamente em não torná-lo real.

Pateticamente_sentimental: Uma tentativa de barrar as limitações da comunicação digital.

Hame: Está bem, pode não ser erro, mas certamente é um risco.

Gardenia: Não há como não existir, o ser humano se envolve muito facilmente quando há

predisposição... e sempre há.

Hame: Há muito já existem outros meios de se transmitir informações pela rede que não se restringem apenas a textos.

Hame: Bem, tenho uma sobrinha que seguiu esses passos e só conseguiu uma barriga e em seguida, um bebê.

Hame: Pessoalmente, conheci aqui poucos que considero amigos mesmo, reais.

Piano: E quanto a você, suas experiências. Não acha você mesmo um refém da SUA imaginação?

Hame: Não, tenho algum controle sobre ela.

Piano: É mesmo, você acredita nisso?

Gardenia: Uia... como se faz isso?

Hame: Como fazer, não sei explicar, mas isso ocorre desde a infância.

Gardenia: Sou escrava do ideal... é uma droga.

Hame: Acho que só o extremo da bitolação distorcida e inconsciente pode me fazer 'chorar' na Net.

Hame: Vou dizer só isso: nada como a experiência real

* Disconnected 
Observar os nicks criando realidades é observar o reflexo da fantasia em operação. Disso não resulta que a realidade tornou-se insana, mas que é bobo separar realidade de insanidade. Não há uma coisa chamada fantasia e outra chamada realidade. Elas explodem uma na outra, não existindo realidade sem fantasia. $\mathrm{O}$ sonho científico da imparcialidade absoluta e do realismo naturalista é, necessariamente, uma fantasia ${ }^{17}$. Não apenas por ser falso, mas porque a fantasia é condição para que o mesmo seja real, pois almejar um retrato perfeitamente simétrico e exato da realidade é provavelmente o ápice da imaginação fantasiosa. E não há qualquer falcatrua no devaneio realista: fantasiar é a condição positiva para a criação da realidade $^{18}$. Uma sempre contaminou a outra, e não há realidade pura assim como não há fantasia total ${ }^{19}$.

Slavoj Zizek ${ }^{20}$, filósofo e psicanalista lacaniano, faz uma interessante análise sobre a cultura, procurando desvendar a paixão pelo real ${ }^{21}$, quase diríamos obsessão. Para ele, essa procura pela potência brutal do real, que se afigura na transgressão em qualquer ordem, remonta a uma necessidade de práticas sólidas, perceptíveis aos sentidos e que ressaltem a concretude do ato, culminando num espetáculo explosivo de fascinação. Ainda que entremeada no seu inverso aparente, o simulacro, a busca ainda é a da experiência extrema, de estetização da violência que é fundamentalmente contrária ao real tal qual compreendido por Lacan, qual seja: da presença de uma ruptura com a ordem simbólica, de uma contradição lógica que define qualquer plano de sentido.

Pode-se entender a concepção lacaniana como tautológica: ainda que a fantasia busque o mais fantástico e imaginoso dos objetos, será em vão, pois no instante mesmo em que se consegue o que se queria, o objeto perde o valor cobiçado, devendo o desejo permanecer eternamente insatisfeito, vazio. É o artificial isolamento da tênue linha entre fantasia e realidade, muitas vezes entendidos como pares opostos, que viabiliza o asfixiante imperialismo da falta. Diferencialmente, fantasia e realidade não devem ser entendidos como elementos contrários um ao outro, mas como integrados, pois é por meio da fantasia que se provê sentido à realidade. Em termos lacanianos, o oposto da fantasia não é a realidade, mas o Real traumático da não-existência do Outro ${ }^{22}$.

É neste sentido que Deleuze e Guattari contestam qualquer entendimento da fantasia como falta. Isso porque não há desejo original, primeiro; desejo tem que ser produzido e aquilo a que aspiramos é em última instância a síntese de desejos. O problema da inexorabilidade da falta em Lacan não é só o ressoar de um estruturalismo congelado e cansado, mas a infelicidade no entendimento do desejo como pulsão domesticada e naturalizada, quando se trata de algo anterior à própria experiência de falta. É esta concepção de desejo que devemos empregar para compreender como o meio em questão pode ajudar na formação de novas relações sociais, novas formas de sentir e desejar. 
O ciberespaço é a derradeira fantasia do capitalismo, porque promete a exploração dos nossos próprios desejos como um material de consumo inesgotável. $O$ sonho do ciberespaço é o sonho da produção infinita. ${ }^{23}$

[01:24-02:08] * Domus entrou no \# literatura

Domus: IRC é coisa de mal-resolvido, inseguro e complexado. Que vem tentar virtualmente o que não consegue na vida real: ser arrogante e perfeitamente seguro, ou literato ou filósofo.

Domus: Estou sendo realista. IRC é a impotência.

Fixx: Por que impotência, Domus?

Cranyx: Seguindo esse raciocínio... o que você é?

Domus: Quem entra aqui levando a sério conversas que não são sérias é tudo, menos sério.

Domus: IRC é o lugar dos Quixotes literários e filosóficos. Eu sou o que descrevo.

Domus: Jô soares e IRC, canal \# Literatura. Essas coisas que servem pros cretinos massagearem a auto-estima. Duas palavras que sintetizam o espírito do IRC: "convincente" e "simplório".

Domus: São os termos utilizados pelos "grandes" mirqueiros. Falta aí "claudicante", "ignóbil",

"pusilânime". Esse é o espírito (e agora eu falo como grande mirqueiro).

Domus: Eu, por exemplo, lia mais que todo mundo na minha idade.

Domus: Eu leio, entendo, e nunca produzo merda nenhuma. Além de textos de MIRC.

Domus: Que discurso mais mirc... Uma eterna tentativa de desprezo. Cada mirqueiro espera uma oportunidade de falar, indiretamente. Eu posso sair dessa e te dar uma tirada que vai te detonar.

Domus: Eu sou melhor e mais arrogante, fica na sua, agora eu te humilhei.

Domus: MIRC, óbvio, putz. Eu sou mirqueiro.

Noexk: Não confunda IRC com mIRC.

Domus: Vá se foder! Não confunda IRC com mIRC? Não confunda \# Literatura com Literatura!

Domus: (estou quase chegando lá)

Noexk: Mirc é só um programa

Spine: Quase lá. Mas você realmente chegou a confundir alguma vez \# Filosofia com Filosofia?

Domus: Como bom mirqueiro, Spine, eu não confundi, não, e só um estúpido como você poderia ter imaginado isso. Você e sua pusilanimidade intelectual...

Spine: Sabe, Dominó. Acho que você vai sacar, rápido, que eu não sou eu. Estou sendo outro.

Domus: Eu sou mirqueiro, já disse. Sabe como funciona isso? É só bancar o mirqueiro revoltado-

conformado. Vou embora. O espírito do mIRC não está mais aqui no \# literatura.

Spine: Sem dúvida. O diabo é achar ele. Tem que ficar trocando de canal.

Domus: Vocês quase se enterneceram comigo

Spine: Não se superestime, Domus. ;)

Spine: Por que você não nos fala um pouco sobre o "espírito do mIRC", Domus?

Pinus: O cara é um Heidegger do chat. Uma Zohar muito doida.

Domus: Por enquanto eu encontrei dois espíritos genuínos no mirc.

Spine: O Pinus é lento que nem uma sujeira de sargeta. Mas é até que legal.

Domus: Um, é o papo, "ow, manowz, di boa, se pá a genti troca uma idéia".

Domus: Não é o \# literatura mas é a maioria. O outro é o \#literatura, o \# filosofia, etc.

Léa Waidergorn, em seu livro sobre comunicação eletrônica ${ }^{24}$, narra a conversa com um garoto devoto ao cibersexo. Bruno, codinome do rapaz, diz propor muito delicadamente a sessão de cibersexo a seus alvos potenciais. Traçando um paralelo com os serviços de sex-fone, lembra que sempre se trata de imaginação e masturbação, ainda que em graus diferentes de interação. Sobre um eventual encontro real, diz não ter medo de se decepcionar, mas de decepcionar a garota, e lembra que não é um rapaz bonito nem no seu ponto de vista, nem no de sua namorada: Acho que é por isso que gosto tanto de um cybersexo. Deixo as garotas me imaginarem como elas querem. Aí, me sinto mais bonito, mais forte... ${ }^{25}$

Pouco adiante, descreve o desespero de um rapaz que se encontrava perdidamente apaixonado por sua amante virtual: para falar a verdade, estou sempre pensando em você. Não vejo a hora de chegar em 
casa e poder conectar, para ler suas mensagens. Léa lembra que tais mensagens são comuns, sendo tão corriqueiro quanto o estranho fato destes apaixonados, no mais das vezes, nunca terem se visto ou mesmo falado por telefone. Para ela, a paixão virtual é um estado alterado de consciência, de concentração das energias numa fantasia. Os amantes não estariam apaixonados por pessoas, mas pelo próprio sentimento de paixão: entorpecidos e viciados em paixão. ${ }^{26}$

Nos termos fenomenológicos de Merleau-Ponty, que pontualmente resvala em um solipsismo bastante asfixiante, pode-se dizer que a comunicação é um processo praticamente inviável, em vista da supremacia do universo imaginário, da proeminência da fantasia individual: Jamais encontramos na fala do outro senão o que nós mesmos pusemos, a comunicação é uma aparência, ela nada nos ensina de verdadeiramente novo ${ }^{27}$. Merleau-Ponty parte do princípio de que a comunhão do sentir só é possível quando da presença mútua dos corpos, que se interpenetram e compartilham alguma coisa, quando há comunicação. Inversamente, isso não seria possível para as consciências, que não se tocam mutuamente: o diálogo apenas faz com que nossas falas toquem sentidos específicos do outro, inacessíveis a mim. E vice-versa. No entanto, olhando para o empreendimento da comunicação, nada mais necessário e sedutor:

Na fala realiza-se a impossível concordância de duas totalidades rivais. Não que ela nos faça entrar em nós mesmos e reencontrar algum espírito único do qual participaríamos, mas porque ela nos concerne, nos atinge de viés, nos seduz, nos arrebata, nos transforma no outro e ele em nós, porque ela abole os limites do meu e do não-meu. ${ }^{28}$

André, que seu nick contava ter 28 anos, entra no canal \#Filosofia ao dia 24 de janeiro de 1999, um domingo, às quatro horas da manhã. Pergunta aos usuários se já haviam sentido estar com uma pessoa, agir como ela, sentir estar dentro dela, mas não poder tocar na pessoa. Depois de algumas interrogações relativas a quê, afinal, André estava falando, as interrogações que resvalavam na metafísica mais tacanha e na filosofia mais barata têm fim e o problema vem à tona: paixão virtual. Isso está me cheirando a amor internético é a frase que coloca as cartas na mesa. Seguido por um definitivo trata-se disso, Samira, a usuária dona da assertiva, conduz uma discussão sobre a condição dos amantes que não existem, que são pura imagem especular.

Você se ferrou, ponto. Horrível, impossível, já passei por isso, que pena, infelizmente e outras categorizações vão delineando o tamanho da catástrofe. Apesar disso, todo mundo já viveu esse engano, assegura. André quer pensar positivo e diz que alguns chegaram até a se casar, que nem tudo são lástimas. Recebe como resposta um nunca mais entro nessa, me machuquei pra burro, e assim por diante. Rapidamente concordam que se trata de um péssimo negócio, quase uma novela que se desenvolve com e por desilusão. 
André: a palavra, para quem está dentro desse buraco, é terrível. Novas visões sobre o amor, sobre o relacionamento. Samira se prepara para narrar sua experiência e, indiretamente, indica que se apaixonou mais por um caractere do que por uma pessoa. Mas tudo são lições de vida, lembra nossa condutora. Talvez se os chats não permitissem conversas tão íntimas, confissões tão profundas, aproximações menos envolventes... o chat é algo perigoso, pois funciona de personalidade para personalidade, concluem. $^{29}$

Ou... de projeção de ideal pra projeção de ideal, corrige um interessado participante. Isso, este é o ponto, lê-se no canal. O problema é quando se é obrigado a separar o que é projeção do que é real. Um problema certamente espinhoso. Mas André lembra que a projeção de ideais é algo normal e rotineiro, que o próprio processo de se conhecer envolve o uso destas idealizações que vão paulatinamente caindo. E, ainda assim, apaixona-se.

Samira, uma mulher de 40 anos, conta como foi se apaixonar por um garoto de 19 anos, com quem manteve um namoro virtual por um ano. A coisa toda começou com algumas mentiras, mortíferas. A pior delas, naturalmente, a idade. Antes disso, juras de amor, horas de ternura, de entendimento recíproco e planos para se atravessar o país por um encontro, em resumo, tudo muito legal. Para se desapegar, um problema.

Testam todos a idade de todos. Querem ver se ficaram escaldados. Parecem experientes, agora. Samira diz achar tudo meio estranho, e se dá conta de que não percebeu a diferença de idade porque não quis. Lá estavam todas as evidências: aqueles silêncios quando eu falava de musicas, estampas... gritos da minha geração... eu não queria ver.

Olha, nós fomos longe, viu? Todos aderem: Falávamos de tudo, concordávamos em tudo, por que então deu errado? Ou ainda: por que não poderia ter dado certo? Ainda me lembro de uma usuária, alguns anos antes, no mesmo canal e no mesmo horário, respondendo: 〈Carmecita〉 de que adianta vida virtual? É quase uma contradição! Nada mais perverso do que um pássaro, além de rebelde, de todo imaterial: prisioneiros da consciência.

Parece verdadeiro em princípio que a consciência só pode encontrar em sua experiência o que ela própria ali colocou. Desse modo, a experiência da comunicação seria uma ilusão. Uma consciência constrói - para X - esta máquina de linguagem que dará a uma outra consciência a oportunidade de efetuar os mesmos pensamentos; mas, na realidade, nada passa de uma para outra. Todavia, como o problema é o de saber como, segundo a aparência, a consciência aprende alguma coisa, a solução não pode consistir em se dizer que ela sabe tudo antecipadamente. ${ }^{30}$ 
Terça, 15 de julho de 1997, 16:12, Canal \# Lux

Ivanhoe: Por favor, entendam o Ivanhoe como Jorge, ou como Gilberto, não importa. Mas por favor, óbvio que vocês sabem que Jorge nem existe aqui em mim, mas ajudem-me;

Ivanhoe: Eu sempre trato os nicks como pedem. Eu não sou este eu aqui.

Ivanhoe: Troquei de nick porque quero me esconder. Estou com vontade de ficar mesmo sozinha fazendo coisas dentro do meu quarto, acho que é a prisão. Tomar banho, pentear o cabelo (?), essas coisas de mulher que de um jeito ou de outro, se arrumam. Enfim, estou com preguiça dessas coisas. Quero me pintar inteiro, eu acho, e me carimbar numa folha de papel enorme e aí mandar pra um concurso que está tendo aqui, escrito assim, no alto da folha: eu estou aqui.

Molly: vocês não arrumam ninguém para trepar de verdade?

ITA: Trepar? trepar... o povo aqui está é passando meleca embaixo da mesa há mó tempão. Molly: Eu até trepei, mas foi tão ruim que nem valeu. O cara foi me comer no banheiro e foi uma bosta. Foi tão bosta que eu disse: Para de me comer, eu vou tomar uma cerveja.

ITA: Que merda...

ITA: Tsc, tsc... mesmo como fantasia é terrível.

Era central para a revolução sexual que os amantes pudessem se relacionar livremente: sexo sem compromisso. Para a revolução digital perpassada pela AIDS, a idéia de se relacionar com pessoas para nunca mais se verem funcionaliza o amor liga/desliga, que não é exatamente uma relação descartável para com o parceiro. Em verdade, nem há parceiros carnais ${ }^{31}$ : aparência, personalidade, estilos de vida e qualquer outro quesito fundamental para a aproximação entre pares apaga-se frente à proeminência das imagens criadas particularmente sobre o outro. Casais brotam com a mesma velocidade com que, no instante seguinte, se desfazem.

Tal como Narciso com seu reflexo, quem trabalha com computadores pode facilmente apaixonar-se pelos mundos que criou, ou pelo seu comportamento nos mundos criados para si por outrem. $O$ envolvimento com mundos simulados afeta o relacionamento com o mundo real. ${ }^{32}$

A história de Narciso é geralmente interpretada como um aviso contra o amor próprio. Narciso viu sua imagem na água e encontrou a morte ao cair devido ao desejo de lhe tocar, de estar mais próximo da sua beleza. Mas há outra maneira de interpretar a história. Narciso apaixonou-se pelo que lhe pareceu ser outra pessoa. A imagem desse outro fascinou-o, pois "objetivava" um sentido de beleza do qual ele apenas tivera uma vaga sensação interior. ${ }^{33}$

A história de Narciso encontra saboroso paralelo no estágio do espelho da literatura lacaniana. Tal momento remonta a matriz simbólica que constrói o Eu numa espiral de significações, até que comecem as identificações com o outro. Isso tudo, importante frisar, muito antes que a linguagem lhe estabeleça sua função de sujeito. Danielle de Oliveira localiza algumas charadas nietzscheanas sobre o espelho:

Ao dizer "se você olhar muito tempo para o abismo, o abismo também olha para você", Nietzsche não evoca somente uma imagem monstruosa ou assustadora; também leva a pensar no processo da especularidade narcísica. Os abismos são extensões tanto de caos como de poros, aberturas líquidas constantes, situações-limite de vida e de morte. É por isso que, ao olhar longamente a superfície líquida do abismo, acaba-se por ver a si mesmo. É o próprio abismo que impede o desvendamento do abismo, pois 
ele se oferece enquanto espelho. Ele é de fato o outro, mas um outro que se escondepresenteando seus visitantes com uma sedutora imagem especular. Esse espelho só é quebrado quando se vai para dentro dele. ${ }^{34}$

Construindo a imagem do self sozinhos, isolados? Nem chega a ser relevante que todos teclem sozinhos, anônimos e anômalos. Mentindo. Pulverizando pequenas mentiras numa vida que não existe. É verdade que a altura não é esta, que a profissão não é aquela e que as juras de amor e pedidos de sexo não são substancialmente diferentes: tudo bits, bytes, mega. Não há o menor conteúdo na virtual mentira virtual. Está muito mais próxima é das inesperadas acelerações de partículas que tais frases representam. Estas frases são mais músicas que propriamente pinturas, valem por si próprias e às vezes andam tão depressa que se avizinham na insuportável distância do irreconhecível; quiçá novo. Não sei porquê os nicks mentem, mas percebo que quando eles querem estar em algum lugar, já estão lá.

Olhando daqui, deste cantinho arredondado, parecem todos senhores da velocidade. Pilotam um fluxo degradante de ansiedade e vontade, algo destrutivo. É como se corressem tanto quanto possível daquela memória que já há muito apagaram, e quando finalmente estacionam vemos que não são serem de fuga. Pode-se ver cruamente que a inquietação não é para voar, mas para entender porque não possuem matéria.

\section{NOTAS}

\footnotetext{
${ }^{1}$ Blanche, por Vivian Leigh em Um bonde chamado Desejo (A Streetcar Named Desire). Direção: Elia Kazan. USA: Warner Bros. Pictures, 1947. P\&B, son., 35mm, Produção: Charles K. Feldman. Roteiro: Tennessee Williams. As falas citadas foram retiradas da cópia em DVD do filme, distribuído pela Warner Bros. Pictures.

${ }^{2}$ Entrevista com Peter Handke. Jornal Folha de São Paulo, Caderno Ilustrada, 19/10/2003, p.6.

${ }^{3}$ Hamman, Robin B. The role of fantasy in the construction of the on-line other: a selection of interviews and participant observations from cyberspace, University of Essex Press, 2000. As citações originais do texto de Hamman são estas:

$<$ Martha > You are, without a doubt, the most amazing person. You turn me on so much it is scary! <Guy> It's all in the mind, darling. (IRC conversation as told by Moore, 1995, p.163.) "There may be a time when we'll attend Weather Theatre to recall the sensation of rain." (Jim Morrison, 1969, p. 64.) "Can anyone tell me how to /join \#real.life?" (IRC user to other chat room users. Quoted in Turkle, 1995, p. 186.)

${ }^{4}$ Henry Bergson, APUD Deleuze, Gilles. O Bergsonismo. São Paulo, 34, 1999. (p.13)

5 Anders, Günther. $O$ antiqüismo do ser humano. A alma na era da segunda revolução industrial. Tradução de Ciro Marcondes Filho. Disponível em: www.eca.usp.br/nucleos/filocom/traducoes.html

${ }^{6}$ Nietzsche, Friedrich. Além de bem e mal. $\$ 146$.

${ }^{7}$ No original: "In order for there to be cyberspace, there have to be people who allow themselves to believe in it". Gibson, Willian. Neuromancer, New York: Ace Book, 1995 (p.51).

${ }^{8}$ Sobre a etnografia do ciberespaço, consultar Turkle, Sherry. O Segundo eu: Os comportamentos e o espírito humano. Lisboa: Presença, 1989; Life on the Screen: Identity in the Age of the Internet. New York: Touchstone Books, 1997. Sobre as abordagens que tomam a perspectiva de Erving Goffman como ferramental analítico, ver Ribeiro, José Carlos. Considerações sobre o processo de gerenciamento de aparências e de informações no ambiente das plataformas interacionais on-line. Revista 404nOtF0und, N. 32, 09/2003. Disponível em: http://www.facom.ufba.br/ciberpesquisa/404nOtF0und/ e também Jupy Jr., Edmar de Araújo. Chats: comunicação e sociedade. Revista 404nOtF0und Ano 4, vol. 1, n 36, ISSN 1676-2916, Fevereiro de 2004. Também disponível em: http://www.facom.ufba.br/ciberpesquisa/404nOtF0und/

${ }^{9}$ Ver Goffman, E. A Representação do Eu na Vida Cotidiana. Petrópolis: Vozes, 1996.

10 "In this circumstance narrow bandwidth becomes a powerful asset, because extremely complex fantasies can be generated from a small set of cues. (...) client and provider mobilize erotic tension by taking advantage of lack - filling in missing
} 
information with idealized information." Stone, Allucquere Rosanne. The War of Desire and Technology at the Close of the Mechanical Age. London: MIT Press, 1995.

11 "Este autocontrole foi uma aquisição evolutiva que surgiu diretamente do processo de evolução social. A interação, ao pressupor a presença corporal dos que estão se comunicando, pode chegar a controlar, mediante os reflexos dos gestos do rosto ou através de sinalizações, se a comunicação será aceite ou recusada. A simultaneidade da interação serve de controle da aceitação de uma comunicação. E isso também em caso de conflito, já que devido a esta presença simultânea a opção de conflito funciona comunicacionalmente". Luhmann, Niklas. Introducción a la teoría de Sistemas. México: Universidad Iberoamericana, 1996. (p.228, $4^{\circ}$ parágrafo). Tradução Livre.

${ }^{12}$ Luhmann, Niklas. Introducción a la teoría de Sistemas. México: Universidad Iberoamericana, 1996. (p.228, 5 parágrafo).

13 "Like most other aspects of computer mediated communication, fantasy is what drives relationships in online chat rooms. This thesis is not a comfortable one for me. I have spent hundreds of hours and thousands of pounds on communicating with people in real time via computer. I have met good friends, learned many things from others, experienced sexual fulfillments all by using a computer with a modem. I feel angered and cheated at the possibility that it is not the others in cyberspace that have done these things for me, it is my fantasies and imagination." Hamman, Robin B. The Role of Fantasy in the Construction of the On-line Other. Cybersociology Magazine. Disponível em http://www.cybersociology.com/. Parece um exercício de escravização constante pela própria imaginação. Nos termos de Baudrillard: "Trata-se de pesadelo na medida em que todos os sonhos são realizados. Ou, dito de outra maneira, tudo o que pode depender da imaginação acaba absorvido pela imagem." Baudrillard, Jean. O elogio radical da parte maldita. Entrevista realizada por Juremir Machado da Silva. Jornal Folha de São Paulo, Ilustrada, 25/11/1998. Versão integral em http://www.pucrs.br/famecos/10-4.html. Essa conotação de "império da fantasia" que o ciberespaço adquiriu também se encontra em outros autores: "(Milthorp) trabalha com um conceito de imaginação, uma fantasia abstrata, eletrizante, que se tornou parte da realidade cultural contemporânea. As relações entre a fantasia e a experiência, expectativas e satisfações, ciência e nossos mitos culturais, são aspectos inextricáveis de sua noção de ciberespaço.” Santaella, Lucia. Culturas e artes do pós-humano - Da cultura das mídias à cibercultura. São Paulo: Paulus, 2003. (p.101). Também Maffesoli, em suas "modulações" junguianas, indica a proeminência da fantasia no ciberespaço: "A 'rede', o 'ciberespaço' que ela promove são certamente uma boa ilustração, em todos os terrenos, de um simbolismo generalizado no qual a fantasia, ou seja, a partilha das imagens, desempenha um papel que não pode ser subestimado." Maffesoli, Michel. A parte do Diabo. Rio de Janeiro: Record, 2004. (p.116)

${ }^{14}$ Sobre este assunto, consultar o capítulo "Emergência Lingüística", neste trabalho.

15 "Bergson afirmava que só havia uma diferença de grau entre o ser e o ser útil: com efeito, a percepção só se distingue do seu objeto porque ela retém dele tão somente o que nos é útil; há mais no objeto do que na percepção, mas nada há nele que seja de outra natureza". Deleuze, Gilles. O Bergsonismo. São Paulo, 34, 1999. (p.42). Tal proposição também é encontrada em Merleau-Ponty, como se vê aqui: "Nenhuma análise pode encontrar num objeto outra coisa além do que nele pusemos." Merleau-Ponty, Maurice. A prosa do mundo. Rio de Janeiro: Bloch, 1974. (p.101).

${ }^{16}$ Lacan, Jacques. Seminário Livro 05. Rio de Janeiro: Jorge Zahar, 1999. Sobre como a fantasia funcionaliza o desejo, relacionando a incompletude do sujeito com os deslocamentos do Desejo, ver: Lacan, Jacques. Os quatro conceitos fundamentais da psicanálise. Rio de Janeiro: Jorge Zahar, 1990, especialmente a estória da sardinha e as diferenças entre o olho e o olhar.

${ }^{17}$ Ciro Marcondes Filho, seguindo um veio nietzschiano, assim comenta a promíscua relação entre fantasia e realidade: "Em verdade, o real parece jamais ter existido. Nietzsche dizia que a verdade não é o principal. A vontade de aparência, de ilusão, de engano, do devir, da mudança (para a ilusão objetiva) é mais profunda, original, metafísica do que a vontade de verdade, de realidade, de ser, sendo que esta última não passa de uma forma da vontade de ilusão. Isto é, 'o mundo é uma ficção'." Marcondes Filho, Ciro. SuperCiber: A civilização místico tecnológica do século 21. São Paulo: Edições NTC, 1998. (p.38).

${ }^{18}$ Talvez fosse interessante retomar aqui a distinção aristotélica entre poíeses e práxis. Diferentemente do sentido que hoje lhe é atribuído, sobretudo pelas pesquisas alinhavadas como "estudos culturais", a poíeses é o ato de fabricação ou invenção de uma realidade exterior, enquanto que a práxis seria o seu engendrar autônomo, algo como uma autofabricação.

${ }^{19}$ David Cronenberg, cineasta das máquinas e dos desejos, disse o seguinte no lançamento de 'Spider', seu filme, digamos, menos cronenberguiano: "Não há realidade no cinema, apenas luz sobre a tela! Essa é a única realidade do cinema, e todas as projeções são feitas pelo público, e não pelo projetor, porque todo o simbolismo é criado pelo público, em um processo semelhante ao do livro - cinema e literatura são, na verdade, duas formas de expressão criadas a partir de sofisticados sistemas tecnológicos. Para mim, e para muitos outros cineastas, um dos principais temas do cinema é exatamente essa questão: o que é realidade?" Cronenberg fala sobre "Spider". Revista Trópico. Disponível em: http://www2.uol.com.br/tropico/palavra_10_1564_1.shl; "Spider - Desafie Sua Mente" (2002). Direção: David Cronenberg. Com Ralph Fienes, Miranda Richardson e Gabriel Byrne. Baseado no romance de Patrick McGrath.

${ }^{20}$ Zizek é um autor conhecido por retomar a temática da crítica à ideologia por veios inauditos. Rechaçando o cenário pósideológico, Zizek atualiza a crítica da ideologia, aproximando-a de elaborações psicanalíticas a respeito da fantasia, tal como Lacan já trabalhara. Fantasia, então, aparece como uma categoria central da esfera política, reconfigurando o próprio conceito de ideologia. Na psicanálise lacaniana, fantasia é a condição estruturante para o desejo, princípio que produz relações para com o objeto. É a cena imaginária onde o sujeito realizará seu desejo e alcançará o caminho do gozo. Sem ela, só existe a angústia solapante da ausência do Desejo. Como defesa contra a angústia, é o mecanismo que investe libidinalmente o mundo dos objetos atribuindo-lhes significado e valor. Ao aproximar fantasia de ideologia, Zizek insiste em uma fantasia social, estruturante nas relações de valor e significação da realidade, dispositivo que seria capaz de criar uma "objetividade fantasmática", ou seja, ideologia. O objetivo dessa operação conceitual é deixar de entender a ideologia como construção meramente reificada e, por isso, apartada dos campos de significação que a cultura gera. É o fim dos "sintomas ideológicos" 
próprios ao estruturalismo analítico, que procura "desvendar a verdade" por meio de uma hermenêutica teleológica. Para um aprofundamento sobre o tema, consultar as obras do autor constantes na bibliografia deste trabalho, sobretudo Zizek, Slavoj. Bem-Vindo ao Deserto do Real. São Paulo: Boitempo, 2003. Ver também Safatle, Vladimir. A política do Real de Slavoj Zizek. Revista Trópico. Disponível em: http://www.uol.com.br/tropico/dossie 5 _1778_1.shl

${ }^{21}$ As assunções que Slavoj Zizek vem trabalhando recentemente permitem interessantes paralelos entre a discussão do capítulo Táticas de terrorismo conversacional e o presente debate. Trata-se de uma "área cinzenta" onde o imaginário encontra, algo bizarro, uma aceleração destrutiva que não é nem tânatos, nem buraco negro. Assim, não é por menos que Zizek, nas suas atuais investigações sobre o terror e o Ethos do terrorista, conclua que o Leitmotiv do homem-bomba não é o desprezo ou horror ao Ocidente, é antes uma espécie de ódio que surge da impossibilidade de oferecer algo em troca, de estabelecer para com o Ocidente uma relação de parecença, originária na condição de alteridade e que não pode ser negociada. Não podendo ser plena, ser radical, ela implode. Ou além, diante da impossibilidade de ser o Outro no capitalismo Ocidental que tudo reduz ao mesmo - o terrorista explode a si mesmo, levando consigo toda a insustentável desigualdade dessa economia de trocas simbólicas, ou da ausência delas. Ato total que se engendra pela ausência de uma comunicação possível, relacional, e que não se caracteriza por uma suposta falta de racionalidade, mas pela abundância mortífera e brutal da mesma. Foi apenas em seu princípio que a racionalidade compreendeu, também, algum sentido. Para tanto, ver Zizek, Slavoj. BemVindo ao Deserto do Real. São Paulo: Boitempo, 2003.

${ }^{22}$ Roman Polanski, presente recentemente no Brasil e tema de uma mostra organizada pelo CineSesc, é outro autor em que a realidade e a fantasia não se separam definitivamente. Eu seu já escrito livro de memórias, abre com a seguinte frase: "Desde que me lembro, a linha entre a fantasia e a realidade esteve sempre embaçada." A frase serve de guia para a obra de Polanski, co-roteirizada em grande parte por Gérard Brach, em que a separação entre real e imaginário é tênue, e em verdade funciona como uma máquina em que a primeira alimenta a segunda, e a segunda produz a primeira. Seus personagens desenham invariavelmente uma viagem entre o que é externo e concreto, cotidiano e comedido, a uma interioridade central, personalística, bizarra e aterrorizante.

${ }^{23}$ Markley, Robert. Virtual Reality and Their Discontents. Baltimore: John Hopkins University Press, 1996, p.74.

${ }^{24}$ Storch, Léa Waidergorn \& Cozac, João Ricardo. Relações Virtuais: O lado humano da comunicação eletrônica. Petrópolis: Vozes, 1995.

25 "Léa: Quais as principais diferenças entre o cibersexo e a masturbação, ou o fone-sexo? Bruno: Na masturbação a 'parceira' faz exatamente o que eu quero, sem que eu tenha que pedir, afinal é minha imaginação funcionando. No cibersexo não é bem assim, não é só imaginação, a parceira também se envolve. Vendo uma revista se vê uma foto parada que te excita, mas fica faltando algo... nos filmes, por mais que você se imagine no lugar do ator, não é você que está lá, então também fica faltando algo. Então o cibersexo é o que mais se aproxima da realidade. Às vezes chega a ser melhor do que com profissionais". Idem, p. $210-11$.

26 “Apaixona-se pelo sentimento, pela felicidade, pelo sonho, muito mais do que pela pessoa real. Na paixão, não se vê os defeitos ou os problemas referentes ao ser amado, vê-se apenas o estado de graça, o prazer. Principalmente nesses casos de paixão virtual, as pessoas apaixonam-se mais por si mesmas, pela sua capacidade de seduzir e se envolver, do que pelo outro. Não estando em contato direto com o ser amado, a paixão que acontece é apenas um reflexo: 'eu me apaixono por estar apaixonado', 'eu me apaixono por uma sensação' em oposição a 'eu me apaixono por uma pessoa'. (...) E essas paixões, por existirem apenas no mundo da fantasia, se tornam às vezes ainda mais fortes que nas relações reais, uma vez que só se vê no outro e só se mostra o que se quer." Ibidem, p.246.

${ }^{27}$ Merleau-Ponty, Maurice. A prosa do mundo. São Paulo: Cosac \& Naify Edições, 2002. (p.27).

${ }^{28}$ Idem, p. 180.

29 ' O conflito entre mim e outrem não começa somente quando procuramos 'pensar' outrem, e não desaparece se reintegramos o pensamento à consciência não-tética e à vida irrefletida: ele já está ali se procuro viver outrem, por exemplo na cegueira do sacrifício. Ver-se pelos olhos de outrem, é ainda por uma dilatação de sua própria vida que ele chega a isso, e portanto ele nega em hipótese a equivalência entre outrem e si mesmo que desejaria afirmar em tese. Em qualquer caso, a coexistência deve ser vivida por cada um. E se alguém comunica-se com alguém, se o intermundo não é um em si concebível, se ele deve existir para nós dois, então a comunicação rompe-se novamente e cada um de nós opera em seu mundo privado, assim como dois jogadores operam em dois tabuleiros distintos, a 100 quilômetros um do outro. (...) As consciências se atribuem o ridículo de um solipsismo a vários, tal é a situação que é preciso compreender. Já que vivemos essa situação, deve haver um meio de explicitá-la. A solidão e a comunicação não devem ser os dois termos de uma alternativa, mas dois momentos de um único fenômeno, já que, de fato, outrem existe para mim." Merleau-Ponty, Maurice. Fenomenologia da Percepção. São Paulo: Martins Fontes, 1999. (p.478-479 e 482).

${ }^{30}$ Merleau-Ponty, Maurice. Fenomenologia da Percepção. SP/RJ: Livraria Freitas Bastos, 1971. (p.189).

31 "Os computadores, reativos e interativos, oferecem companhia sem a reciprocidade e complexidade de uma relação humana. Seduzem porque proporcionam uma oportunidade de se possuir controle absoluto, mas podem levas as pessoas a uma paixão pelo domínio e pela construção de um mundo próprio e privado" Turkle, Sherry. O Segundo Eu - Os computadores e o espírito humano. Lisboa: Presença, 1989, p.19.

${ }^{32}$ Idem, p.72.

${ }^{33}$ Ibidem, p.133. Evocação também bastante presente, inversamente, em Baudrillard. Segue: "Nada mais se reflete de fato, nem em espelho, nem em abismo (que nada mais é que o desdobramento infinito da consciência)". Baudrillard, Jean. A Transparência do Mal: ensaio sobre os fenômenos extremos. Campinas: Papirus, 2003, (p.10).

${ }^{34}$ Oliveira, Danielle Naves. Poros ou as passagens: reflexões sobre a epistemologia da comunicação. COMPÓS - $12^{\circ}$ Encontro Anual da Associação Nacional dos Programas de Pós-Graduação em Comunicação, Recife, 2003. 
Uma máquina poética que fizesse proliferar poemas inumeráveis, um gerador de textos, impulsionado por um movimento próprio, no qual palavras e frases pudessem emergir, aglutinar-se, combinar-se, para depois desfazer-se, atomizar-se, em busca de novas combinações

Mallarmé

Escrevo para mostrar que é possível realizar ações juntas, justapostas, e não explico nem demonstro pois odeio o bom senso e cuspo na cara da humanidade Manifesto Dada

Uma linguagem conquistadora, que não se limite a enunciar o que já sabíamos, mas nos introduza a experiências estranhas, a perspectivas que não serão as nossas e nos desfaça enfim de nossos preconceitos.

(...)

A palavra de outrem não somente desperta em mim pensamentos já formados, mas ainda me arrasta num movimento de pensamento de que eu não teria sido capaz sozinho, e me abre finalmente a significações estranhas. É preciso então aqui que eu admita que não vivo somente meu próprio pensamento mas que, no exercício da palavra, eu me torne aquele que escuto.

Merleau-Ponty ${ }^{1}$ 
É impossível entender a linguagem do IRC desvinculada da maneira pela qual o meio funciona, de sua estrutura arbórea e emergente. Nos canais, impera uma conversa que se caracteriza pela ausência de ordenação e entendimento mútuo, dado que os falantes são muitos e a possibilidade de haver uma checagem da interpretação é operacionalmente impraticável. Não existe a confirmação do entendimento sobre um enunciado, típico de uma conversa normal.

Essa fratura na ancoragem do co-entendimento faz com que o usuário não objetive sua conversa a uma única pessoa, mesmo quando conversa privativamente com um só usuário. Pode-se objetar que isso ocorre porque se está, circularmente, conversando consigo mesmo. Essa característica - de fragilidade no entendimento e checagem desse entendimento - faz com que a conversa adquira a dinâmica de uma performance, de uma apresentação não direcionada a um único interlocutor. Maria do Carmo Sabbag, em um estudo sobre a percepção lingüística nos chats $^{2}$, conclui que a dinâmica dessa conversação se pauta por um discurso metalingüístico, ou seja, da manifestação explícita das estratégias, ao mesmo tempo em que se encontram presentes características de discurso natural. Essa mistura particular do discurso cibercultural fez com que Leland $\mathrm{McCleary}^{3}$ caracterizasse as conversas em listas de discussão virtuais como um híbrido de conversa e carta: algo não-assinalável.

A contribuição do universo ficcional para esse debate é por certo muito rica. Em uma curiosa entrevista ${ }^{4}$ entre Ricardo Piglia e Roberto Bolaño, discute-se a estranha relação que o compositor Eric Satie mantinha com seus admiradores ou curiosos: ao receber uma carta, nunca a abria, mas sempre respondia elas todas. Satie apenas lia o nome do remetente e escrevia uma carta em resposta. Quando as cartas, fechadas, foram encontradas, resolveu-se publicá-las junto com as respostas de Satie. Piglia diz que se trata de uma fantástica correspondência na medida em que vai à essência do diálogo, isto é, agentes falando de coisas absolutamente diferentes. De maneira inversa, Bolaño replica dizendo que à parte uma provável deferência pelo interlocutor - dado não deixar ninguém sem resposta - o conjunto da correspondência é uma lúcida aceitação da impossibilidade última do diálogo. Ou seja, de Piglia a Bolaño, a gradação da incompreensão e (in)comunicabilidade no diálogo é considerável mas irredutível.

Mas essa lacuna entre o dito e o entendido não é, exatamente, nenhuma novidade. Na dramaturgia há um famoso truque que consiste em tomar um mal-entendido em seus desdobramentos cômicos. A comédia burlesca, sobretudo, faz constante uso da assim chamada conversa cruzada, que ocorre quando uma pessoa diz algo e seu interlocutor, ingênua ou maliciosamente, a toma por outra. A graça consiste no fato da conversa continuar apesar do perfeito desentendimento entre ambos. O diálogo se mantém porque há uma espécie de simetria entre as primeiras e segundas intenções, e as mensagens se prolongam indefinidamente nesta conjugação de sentidos que é exterior à acepção literal dos termos. A comédia de 
erros funciona, assim, através da tensão gerada no deslocamento de contextos, permitindo a antecipação da piada e atuando no caráter reiterativo de uma graça que se faz por meio do desentendimento.

A dinâmica do humor provocado pela conversa cruzada não é nada sutil, sendo até mesmo grosseira. Trata-se de um subgênero populesco, tomado no mais das vezes como limitado e de pouca sofisticação. O que normalmente se esquece é que a dinâmica da interação na conversa cruzada é inerente a qualquer comunicação. Isso porque qualquer troca de mensagens entre emissor e receptor deve invariavelmente deter algum grau de incompreensão e de mal-entendido5. Essa falha comunicacional pode ser extraordinária ou inexpressiva, mas não pode estar ausente, dado que a inexistência dessa falha reincidente implicaria na impossível condição de o emissor guardar uma moldura de referências idêntica às do receptor, condição impossível no que respeita as operações cognitivas e comunicacionais.

O humor do diálogo cruzado atenta diretamente para o exagero, criando diversão no lugar da obscura fatalidade que é a limitação expressiva, característica do opaco discurso lingüístico. Vale lembrar dessa modalidade de humor na medida em que, assim como as disjunções dos chats, ele também trabalha com as áreas de sombra e ruído que a interação entre o eu e outrem inevitavelmente produz. É uma espécie de espelho reflexo que lida com a precariedade do mundo da linguagem, possibilitando comunicação onde a simbólica prisão da vida, a linguagem, se mostra em toda sua impotência. Percebe-se rapidamente que o sentido, que é a unidade que permite o funcionamento da máquina lingüística, é frágil. Mesmo nos diálogos mais cristalinos, ainda paira a dúvida de saber se o que dissemos e o que ouvimos confere com o que pensamos e o que achamos que o outro pensa. Típico da impotência comunicativa, pesa-nos a desconfiança do entendimento.

Os chats, por sua vez, instauram esse entendimento em uma outra escala, que não é individual, que não está circunscrita à dinâmica de emissão e recepção. É como se o diálogo fosse supra-individual, um multilogue, como já fora anotado por diversos analistas. Não é apenas a questão da falta de feedback regulador resultando em diálogos mais soltos, pois não são propriamente usuários dialogando, mas canais gerando um texto que não é o resultado simples da reunião de falas e intervenções. Uma das chaves para se entender essa constituição discursiva está no elemento bottom-up (de baixo para cima) de um canal. Em oposição ao discurso que profere, que se faz de cima para baixo (top-down), organizado por um sujeito discursivo, um canal de IRC é organizado pela emergência de múltiplos agentes que apenas digitam, tentando alguma frágil interação. É claro que nessa concepção, de natureza rigorosamente operacional, a categoria de Sujeito não cabe, não existe.

A emergência ${ }^{6}$ é a propriedade de sistemas que não possuem um centro organizador ou uma diretiva clara de como operar. Os objetivos e as próprias maneiras de se efetuar uma ação são determinados a 
partir da própria interação entre as partes. Como método de organização em diversos sistemas complexos, Steven Johnson ${ }^{7}$ já indicou didaticamente sua importância em formigueiros, cérebros, cidades, inteligência artificial, softwares de computador e demais emulações da vida e de sistemas. Os próprios organismos vivos, aparentemente, não podem abrir mão das propriedades emergentes.

Esse é um fator crucial na compreensão do fenômeno das salas de bate-papo, dos clientes multiusuários para conversas esquizofrênicas ${ }^{8}$. É salutar que a estrutura do IRC tenha sido feita por uma série de códigos, regras e comportamentos determinados por usuários que muitas vezes são, eles também, os próprios programadores que fazem o sistema funcionar. A emergência, categoria que pode nos ajudar a entender a estratificação dessa linguagem, está emaranhada nos elementos mais viscerais desse sistema de comunicação.

Em meio a este ambiente copiosamente técnico que é a Internet, surge um ambiente de verbosidade e humor onde seus habitantes são amantes da palavra. Não deixa de ser intrigante notar que o IRC é um canal de diversificação, de entretenimento e escapismo, qualidades que ali são conjugadas de maneira a forjar mundos, termos e grupos que se fazem e desfazem por meio de jogos de palavras. Não por menos, a última instância do poder neste ambiente não é a função do operador, mas o respeito que um usuário adquire entre seus pares, sua capacidade em concentrar atenção no seu nick. Não se trata apenas de uma terapia grupal por meio de palavras, mas de um relacionamento que se estabelece reconhecendo o poder de falar e ler: o usuário que perturba o sistema é ignorado, banido e isolado dos outros.

O conceito de comunicação, entretanto, tem contornos e intenções integradoras, herança de um humanismo que relacionava fenômenos com a interioridade dos indivíduos. É como se mesmo o processo comunicativo, que trata fundamentalmente de relações entre unidades, e não exatamente das unidades, pudesse ser compreendido como uma essência que atravessava toda manifestação humana. A comunicação, quis-se, deveria se dar a nós como uma estrutura irredutível e palpável, delimitada e esquadrinhada. Mas não é assim, e os chats podem bem servir ao propósito de elucidar esse ponto.

É natural que o questionamento desse ponto de vista surja em um momento em que os circuitos elétricos reorientam toda a lógica de produção. Estruturas estanques ilustram partes separadas, e mesmo quando há relação, há também contenção, modelo que já evidenciava suas fragilidades. A atual era de aceleração e informação flerta com categorias mais fugazes, como o fluído, o fundido, o espectral.

Do ponto de vista da linguagem, essa transição é ainda mais clara e interessante. Ao necessário aferimento do valor de verdade dos discursos, próprios do metarelato, a linguagem dos chats opõe uma versatilidade avessa a checagens. A máquina de produção dos chats não é exatamente uma aberração 
alienígena de produção de vulgaridades. E a aparente ausência de relação com o tecido social é enganosa ${ }^{9}$. É exatamente a falta coesão da realidade que confere a essa linguagem uma característica solta, impassível e sem checagem. É de certo modo uma libertação, por inusitado que seja a linguagem cumprir uma função outra que não a de ferramenta da comunicação. A ausência de uma materialidade nesse tipo de texto também é sintomática da falta de sustentação de uma suposta responsabilidade daquele que fala, e sobre o que fala. Aqui, a explosão destruidora da tríade semiótica atenta para um curioso juízo: essa linguagem pode vir a ser um canal válido para que as pessoas expressem o que querem dizer, e piorando, desejarem essa expressão.

Talvez seja o caso de se questionar se temos ainda aquilo que entendíamos como linguagem e comunicação. Pois essa relação de desentendimento recíproco que gera entendimento tácito é contrária ao princípio fundamental da comunicação lingüística, que é o entendimento ${ }^{10}$, a inteligibilidade entre aquele que fala e o interlocutor: Alter e Ego. Se a linguagem começa a ultrapassar essa relação cibernética de entendimento é porque sua dinâmica se diferenciou demasiado e o esquema não dá mais conta do fenômeno. Piorando, talvez seja o caso de perguntar se não estamos tratando de uma produção maquínica que transcende o próprio signo e, em ultima instância, o próprio corpo. Que o signo já se separou do referente é uma ocorrência que qualquer simulacro evidencia sem menos. O que estamos tratando aqui é a aventura desse signo sem referente estar gerando outros signos, numa dinâmica que não comporta a tríade semiótica porque imediatamente descarta o referente e o próprio significante tem importância reduzida, efêmera. $\mathrm{O}$ sentido desliza e parece se sentir muito à vontade.

Mas essa fratura não é exatamente uma novidade. A língua, que supostamente podia tudo traduzir e explicar, não se tornou impotente apenas agora, de um instante para outro. Mesmo nas mitologias barthesianas, essa faceta obscura da linguagem já fora assinalada no conceito de mito, que era então entendido como um sistema criador de significações que não podem ser discutidas, servindo ao propósito de mascarar uma fratura sígnica; espécie de amálgama de signos que não devem ser esclarecidos e que encobre aquelas camadas que a linguagem não se dispõe a mediar. Tais mitos circulariam em abundância nos media, sistema por excelência de significações indiscutíveis, um arranjo que mascara o desamparo humano no reino da linguagem. Não se trata de uma manipulação aberrante: só pode haver sociedade onde estes mitos existirem, emprestando sentido a um corpo de idéias que faz as pessoas se reunirem ao redor de crenças e encobrindo a insuportável condição de não haver uma consolação enunciável. Não é de hoje que nossa ferramenta primeira de comunicação é falha.

Com isso, a linguagem nunca ofereceu um lugar confortável para se viver. A frágil morada do homem, sua língua, desmonta-se e se prova completamente impotente frente aos abalos necessários à relação entre significante e significado, ao acaso que opera nessa relação. Como não há nenhum referente último 
para assegurar a estabilidade das significações, a angustiante condição da linguagem é um suntuoso exemplo da instabilidade e insuficiência de qualquer tentativa de pormenorizar o objeto dentro de alguma permanência, de uma imobilidade ${ }^{11}$. Os chats só se aproveitaram de uma fenda necessária ao aparato discursivo para ali criarem seus pequenos mundos virtuais, suas fantasias verbais. ${ }^{12}$

Mas não é uma fatalidade inocente. Quando o deslizamento entre o significante e o significado, que produz os deslocamentos de sentido, congela, se paralisa, moldando uma ancoragem plena de um no outro, cristaliza-se aquilo que entendemos por ideologia. As coisas começam a fazer sentido, o claro e inequívoco sentido ideológico ${ }^{13}$. O mito, assim como a ideologia, esconde dos sujeitos a condição inevitável de que tudo é transitório, processando-se ininterruptamente nas relações de troca, materiais e simbólicas. O problema é que a linguagem, que já é fendida na sua constituição mesma, parece evocar e fomentar essas construções mitológicas: trata-se de um sistema viciado.

Essa possibilidade questiona as idéias fundamentais que ratificam a consagrada lingüística estrutural, na medida em que a produção poética não é mais resultado de um discurso singular que pertence ao discurso coletivo; é o próprio tempo coletivo que engendra uma poética desprendida dos discursos singulares. Não é que os agentes sejam nulos, é que a relação entre eles, até então entendida como geradora de significados, se desvincula desses agentes. A lingüística entende que é na relação sintagmática, e não na paradigmática, que tais significados são produzidos. Mas e se a própria relação se complexifica excessivamente, havendo não relação entre pares, mas relações entre relações?

Pois não se pode negar que o falar adquiriu uma monstruosa atrofia. Quando se conversa, os elementos disponíveis para intercambio entre eu e outrem se tornaram invariavelmente o mesmo, o igual, numa espécie de índice de palavras que pertencem a um único glossário. A possibilidade de operação no sintagma, que cria significado, se mostra gasta, tautológica. Troca-se sempre o idêntico pelo mesmo, pelo igual. Mas e se a relação sintagmática se complexificasse a ponto de, ela mesma, se tornar um elemento a mais na troca?

Mas então que palavra é essa que o chat faz uso, que produz? É uma linguagem outra. Não é um canal de diálogo, mas de multilogue. Multilogue porque a dinâmica de relação não se dá entre pares complementares que produzem um discurso dono de um sentido específico, mas uma conversa aonde o sentido escapa a todo instante, isso quando não é inteiramente impenetrável. A prosa, de maneira simétrica, é feita por muitos pontos que raramente convergem para um tema único, central. Olhando de fora, parece um amontoado de gente falando uma língua coletiva: não existe enunciação individual nem sujeito de enunciação. Existem relativamente poucos lingüistas que tenham analisado o caráter necessariamente social da enunciação. O caráter social da enunciação só é intrinsecamente fundado se 
chegamos a mostrar como a enunciação remete, por si mesma, aos agenciamentos coletivos. ${ }^{14}$

O ponto de vista da lingüística estrutural trata de um regime de signos que se encontra, efetivamente, inapto para abordar um sistema multimodal. Sua lógica é a de um eterno devedor e um terno credor, mercantilizando alternadamente os possíveis significados. É uma lógica, então, que não basta, pois o próprio signo se capitalizou.

Isso quer dizer que um signo não se remete apenas a um outro signo, e que, de signo em signo, o sentido possa fluir circularmente, sempre retornando como um bom filho. Ocorre que os signos não constituem apenas uma rede infinitamente circular. Quando se pensa em todo um regime de enunciados que flutuam, que perambulam através das cadeias, é porque a segurança estrutural deste sistema circular ficou pequena demais. O significante pode significar outra coisa além da redundância miserável de polaridades que não admitem um terceiro, pois aqui, não conta apenas a circularidade dos signos, mas toda uma multiplicidade de círculos e de cadeias. O sistema de ordenação do sentido explode nele mesmo, gerando sistemas paralelos ilimitados. Os signos não remetem apenas a um segundo signo do mesmo círculo, mas a um terceiro signo de um segundo círculo: espiral de relações entre signos de círculos diferentes ${ }^{15}$. É esse processo de diferenciação que não cabe na lingüística estrutural. Trata-se de uma concepção semiológica outra, marcadamente esquizo ${ }^{16}$, que tenciona matérias semióticas que ainda não se formaram com matérias que, fisicamente, também não se encontram plenamente terminadas.

\begin{tabular}{|c|c|}
\hline 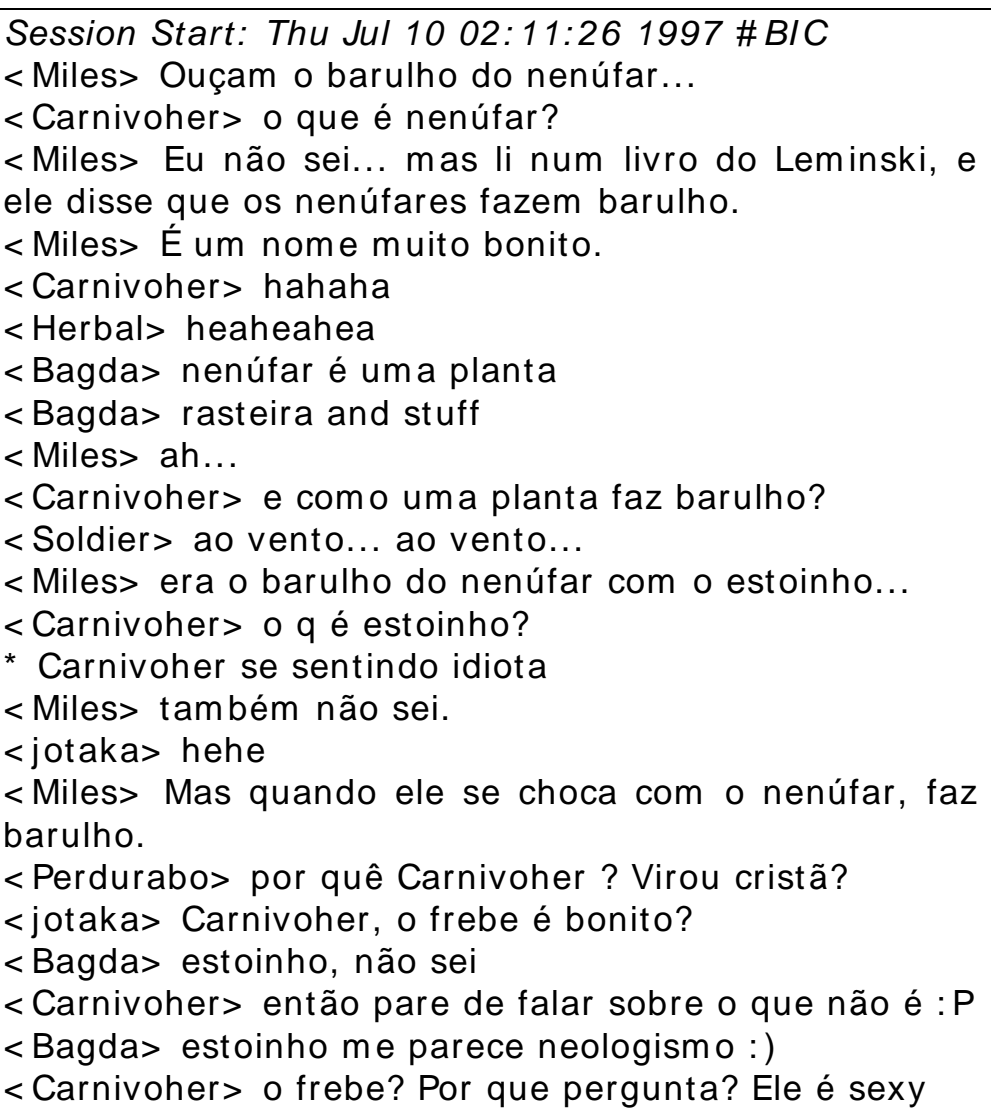 & $\begin{array}{l}\text { fica bem, nenúfar com estoinho } \\
\text { estoinho é o farfalhus sem entus... } \\
\text { er> perd.. hahaha } \\
\text { agda, talvez seja... } \\
\text { sexy? hmm } \\
\text { Talvez eu seja o quê? Sexy? } \\
\text { er> sim... interessado, jotaka? } \\
\text { Nah, eu sou Foxy. } \\
\text { H (Secret@xxx.ppp.matrix.com.br) } \\
\text { \# BIC } \\
\text { er> o q é foxy? } \\
\text { ler em lapso de burrice } \\
\text { uuuh... Foxy Lady... Here I come } \\
\text { coming to get ya... } \\
\text { não, prefiro kids } \\
\text { foxy é a namorada da hazel.. } \\
\text { er> você é gay, jotaka? } \\
\text { não } \\
\text { er> quem é hazel? hahahaha } \\
\text { gíria anos } 60 \text { para "gostosa" } \\
\text { gay é o meu pai } \\
\text { eu sou bi } \\
\text { er> ahhhh } \\
\text { "tesuda" } \\
\text { er> oui } \\
\text { Mannh... hmm... }\end{array}$ \\
\hline
\end{tabular}


Estes diálogos transcritos não são banais, apenas, porque foram extraídos das linhas que lhe precederam e que lhe sucederam, mas porque foram amputados da fantasia do seu universo ${ }^{17}$. Tais diálogos, capengas, só podem mostrar sua existência quando imbuídos não apenas da dinâmica veloz das conversas online, mas do fluxo ininterrupto de frases que não coordenam um sentido, que coordenam sobretudo um vetor, um fluxo e uma cartografia próprios. São máquinas de produção de texto que quando acionadas fazem correr uma longa fileira de atratores de subjetividade. Uma fábrica invisível, uma produção incorpórea.

\begin{abstract}
Significante e significado se fundem por um curto-circuito poeticamente necessário, mas ontologicamente gratuito e imprevisto. A linguagem cifrada não se refere a um cosmos objetivo, exterior à obra; sua compreensão só tem valor no interior da obra e se acha condicionada por sua estrutura. A obra como um todo propõe novas convenções lingüísticas a que ela se submete e se torna a chave de seu próprio código. ${ }^{18}$
\end{abstract}

Ademais, as trocas entre os agentes acima indicados se forjam arbitrariamente, e os sentidos que o enunciado passa a negociar na relação comunicacional da virtualidade acabam por escapar aos próprios agentes $^{19}$. O que prevalece é a transversalidade da significação, que faz uso das operações efetuadas pelos partícipes, mas onde o sentido repousa em uma outra ordem, esta bastante longe de apreensão pela análise meramente lingüística ${ }^{20}$. Isso porque se trata de um sistema de comunicação que é engendrado por recorrentes contradições internas entre o interesse inicial na enunciação, e o sentido que estas vão adquirindo no jogo comunicativo. Vale lembrar de Benveniste, que indicava que um enunciado performativo não significa nada fora das circunstâncias que o fazem ser o que foi ou é. O problema é que estes enunciados não significam nada nem mesmo dentre das circunstâncias que o geraram. Estas circunstâncias então em permanente deslocamento: Uma máquina abstrata jamais é linguageira, mas molda as conjugações, as emissões e as continuações dos fluxos totalmente diferentes. Não há metáfora mas apenas conjugações ${ }^{21}$.

Hakim Bey, de maneira algo irônica, satiriza o esforço de Chomsky na procura de suas "gramáticas inatas". Indicando seu componente metafísico e hermético, satiriza o esforço do lingüista e ativista na procura de uma fórmula para o sistema lingüístico. Pouco depois, traça um curioso parágrafo sobre as anotações de Saussure, postumamente publicadas, sobre os anagramas na poesia latina.

Para Hakim Bey, o lingüista suíço estava no encalço dos processos que fugissem à dinâmica entre signo e significante. Ou seja, é como se houvessem indícios de que algo acontece dentro da linguagem, sem ser imposto por um fora, por uma ordenação apriorística de significação. Essa possibilidade metalingüística funcionaria segundo uma complexidade auto-expansiva, tal como o lingüista teria examinado nos poemas acrósticos, em que seus números - diante de qualquer tentativa de quantificação - escapariam 
como se fossem equações não-lineares: além disso, ele começou a encontrar os anagramas por todo lado, mesmo na prosa latina. Começou a se perguntar se estava tendo alucinações, ou se os anagramas eram um processo natural inconsciente da parole. Abandonou o projeto ${ }^{22}$. O paralelo com os sistemas multilogues de bate-papo é rico e interessante:

Se quantidades suficientes de informações desse tipo fossem digeridas num
computador, começaríamos a ser capazes de modelar a linguagem e termos de sistema
dinâmicos complexos? As gramáticas, então, não seriam 'inatas', mas emergiriam do
caos espontaneamente como 'ordens superiores' que evoluem, no sentido da 'evolução
criativa' de Prigogine. As gramáticas poderiam ser pensadas como 'Estranhos
atratores', como o padrão escondido que 'causou' os anagramas - padrões que são
'reais', mas que têm 'existência' apenas em termos dos sub-padrões que manifestam.
Se o significado é alusivo, talvez seja porque a própria consciência, e portanto a
linguagem, seja fractal.

A provocação disparada por Bey alimenta algumas premissas aqui trabalhadas sobre a linguagem, na medida em que a entende como uma sobreposição à mera representação ou mediação. Isso se daria não por alguma outra estrutura, externa, mas porque a dinâmica fabril de intersecções estabelece essa possibilidade de cruzamento. O foco não é o mapeamento dos significados, mas sua geração. Para o autor, é como se a criação de significados, forjada de maneira arbitrária pela linguagem, pudesse criar linguagens a partir do próprio empobrecimento semântico.

Por isso o conceito de multilogue de Gary Shank ${ }^{24}$ é interessante: resultado da tentativa do autor de entender a natureza semiótica da Internet, que não é nem oral nem escrita. Partindo de Roman Jakobson e sua noção de comunicação como uma tríade de emissor, receptor e mensagem, indica que haveria três maneiras básicas de se conversar: monólogo, diálogo e discussão. Ou seja, os casos em que há apenas um emissor e um ou vários receptores; os casos em que emissor e receptor trocam de posição e os casos em que um emissor envia uma mensagem e os receptores, múltiplos, iniciam recorrentes trocas de posição. Apesar deste modelo, o da discussão, se aproximar bastante dos chats, Shank lembra que na discussão, embora seja fundamental que os receptores assumam o lugar de emissores, o emissor inicial ainda mantém o controle do fluxo de informação, da conversa. Exemplos claros dessa tipologia podem ser o monólogo ou leitura de um texto, o diálogo entre pessoas e o debate acadêmico, por exemplo.

Entretanto, nenhuma dessas modalidades abarcaria a promiscuidade de emissores e receptores que não seguem nenhuma linha de direção, tal como nos chats: os modelos lingüísticos de leitura não capturam a dinâmica do signo praticada na comunicação pela Internet. Um novo modelo lingüístico se faz. necessário. Eu o chamo de multiálogo (multilogue) ${ }^{25}$. 
O multilogue se pauta por um número impreciso de participantes e onde há, também, um emissor inicial. No entanto, uma vez que o pavio da mensagem é aceso $\left(\right.$ thread $\left.^{26}\right)$, a comunicação não fica mais sobre controle algum, nem mesmo do emissor inicial. Isso ocorre pela falta de necessidade de um retorno pontual ou mesmo de troca de posições que a estrutura da Internet proporciona. Em uma espécie de hibridização lingüística, o multilogue guarda a flexibilidade de participação própria à linguagem oral, onde qualquer interessado pode se juntar ao debate rapidamente sendo, no entanto, claramente ouvido. Da linguagem escrita, o retorno objetivo sobre pontos que foram grafados, escritos e então passíveis de aprofundamento, crítica ou correção: uma espécie de tensão se mantém entre ambas as modalidades.

De maneira ilustrativa, Shank lembra de um fato algo cômico a respeito de uma mensagem que ganhou vida própria ${ }^{27}$, efeito comum nas mensagens do ciberespaço: um membro de uma lista de discussão sobre Pesquisa em Educação acidentalmente enviou uma mensagem pessoal, que versava sobre a importância de se manter a porta da geladeira fechada, para toda a lista. Apesar de o autor ter se desculpado imediatamente, muitos usuários aparentemente não viram o pedido de desculpas e tomaram a mensagem como uma crítica sobre a área de pesquisa debatida na lista, a Educação na atualidade. Rapidamente a metáfora ganhou vida própria, com usuários questionando a importância daquilo que a geladeira guardava, a dificuldade em se manter a porta fechada e mesmo a possibilidade de a porta não poder ser efetivamente fechada. Ninguém pode controlar o significado das frases, nem tampouco o sentido da conversa que começou a se expandir.

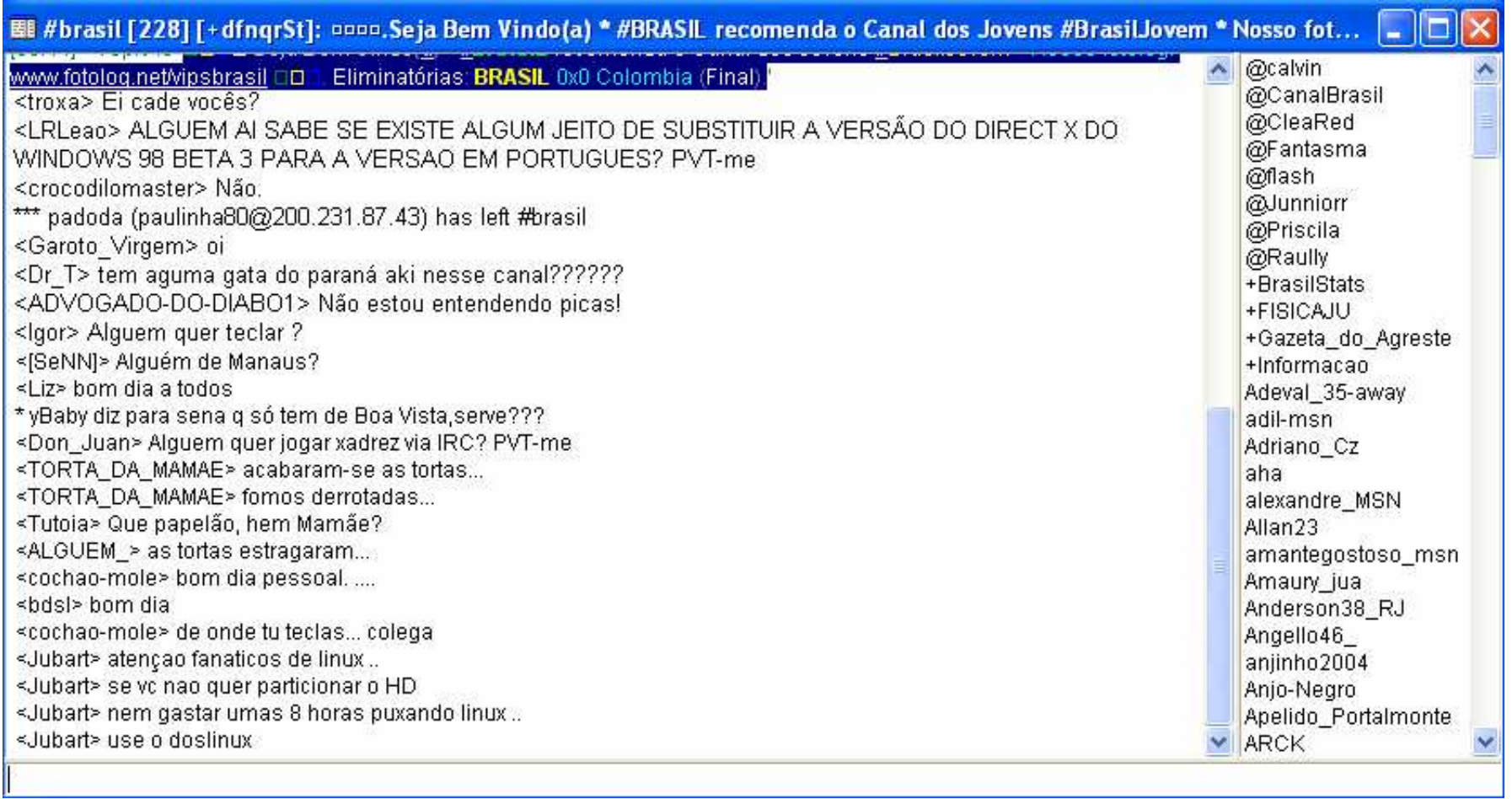

Assim, mesmo que a abordagem de Shank sobre o multilogue adote um funcionalismo preocupado com as implicações semióticas, trata-se de uma perspectiva que indica que a hibridização entre círculos de 
signos ultrapassa a própria cadeia de onde se originaram. A conversa cruzada, de que falamos no início, cria uma outra conversa onde os participantes podem até ser elementos chave, mas não são os únicos ${ }^{28}$. A complexificação cibernética dessa troca, indicada pelos autores, faz implodir os conceitos de diálogo, monólogo ou debate em prol de um "multiálogo". Curiosamente, Shank adverte para o fato de que tal desafio nos faz adentrar não a uma Era da Informação, como costumeiramente toma-se como certo, mas a uma Era do Sentido.

Essa é uma tese especialmente interessante a este capítulo, a proposição de que tal linguagem se estrutura por elementos da emergência não organizados de maneira sígnica. Isso se daria não apenas porque nos tais "multiálogos" os sentidos sejam abundantes - já que o próprio IRC é um canal de polissemia inesgotável. O que marcaria essa escritura é o peculiar sentido de realidade que engendra uma narrativa dessa natureza, onde a possibilidade de um sentido único, ou mesmo de sentidos claros e precisos, não é dada. Assim, poder-se-ia falar em uma Era do Sentido não porque sejamos todos perpassados por muitos sentidos em nossas vidas, mas porque o sentido nos escapará, estará invariavelmente além das nossas próprias operações lingüísticas. Trata-se de uma tese que implicitamente reconhece a impossibilidade de sermos senhores do (nosso) sentido.

Essa propriedade emergente da linguagem, sem qualquer coordenação universalista, é de todo interessante em relação ao desmanche da "interpretose", das inúmeras doenças do signo tais quais apontadas por Deleuze. No fulcro dessa escritura, uma especial ausência de estilo, talvez uma assintaxe, uma agramaticalidade onde a linguagem não mais se define pelo que pode dizer nem pelos elementos que a tornam significante. A saída do universalismo significante viabiliza uma maquinaria de escrita, que é mais um processo do que uma meta, é antes produção contínua do que expressão. Alguém poderia facilmente objetar que não seria mais, então, linguagem, ao que se pode dizer que é exatamente disso que se trata: de certa comunicação, e não apenas de certa linguagem ${ }^{29}$ - uma manifestação que a compreende, mas que lhe escapa. 


\title{
NOTAS
}

\begin{abstract}
${ }^{1}$ Merleau-Ponty, Maurice. A prosa do mundo. Rio de Janeiro: Bloch, 1974. (p.101; 128).
${ }^{2}$ Sabbag, Maria do Carmo. O chat e a percepção lingüística em um curso de inglês on-line. Dissertação de Mestrado: Lingüística Aplicada, PUC - São Paulo - 2002.

${ }^{3}$ McCleary, Leland MacCleacry Emerson. Aspectos de uma modalidade de discurso mediado por computador. Tese de Doutorado, Linguística, FFLCH-USP, 1996. Ver também: Honeycutt, Lee. Comparing E-Mail and Synchronous Conferencing in Online Peer Response. Written Communication, Vol. 18, No 1, 26-60. Sage Publications, 2001.

${ }^{4}$ Histórias Extraordinárias, Jornal Folha de São Paulo, Mais! 12/09/04. Disponível para assinantes do jornal em: http://www1.folha.uol.com.br/fsp/mais/fs1209200404.htm
\end{abstract}

${ }^{5}$ A história da comunicação é, também, a história da incompreensão. No que respeita a relação entre culturas diferentes, é impossível dissociar a geração de novos significados - a criação de elementos diferenciados que se originam no choque entre culturas díspares - deste elemento sempre marginalizado: a incompreensão ou o mal-entendido. A este respeito, Todorov indicou precisamente as inúmeras variações que um termo, uma idéia ou mesmo um projeto adquiriu ao longo da Conquista da América, apesar de todos os esforços de tradução, por parte dos espanhóis, e de compreensão, por parte dos indígenas. Ver: Todorov, Tzvetan, A conquista da América: a questão do outro. São Paulo: Martins Fontes, 1996. Nessa perspectiva dos estudos culturais, o veio da incompreensão é ainda mais rico, tal como se vê aqui: "No âmbito da história cultural, está provado o fato de que, entre culturas estranhas, a incompreensão tem efeitos muito mais criativos que a própria compreensão. Kirk Varnedoe demonstrou em seu livro A fine disregard o terrivelmente complicado ping-pong das incompreensões que, por assim dizer, propiciaram o influxo da xilogravura japonesa em van Gogh e Degas: os japoneses do século XVI entenderam mal o princípio da perspectiva euclidiana e construíram sobre ela uma versão diferente do princípio europeu, resultando na elaborada arte xilográfica japonesa. Isso possibilitou, por sua vez, que van Gogh e Degas desencadeassem a revolução artística européia do século XX, pois que esta se iniciou com um suave tratamento modernista da perspectiva euclidiana. Pelo que se vê, a linha reta da compreensão não é exatamente o ponto de partida nem o objetivo da comunidade do saber intercultural." Wackwitz, S. Alles hat seine Grenzen. Vom fragwürdigen Nutzen kultureller Lerngemein-shcaften. IN: Beck, Ulrich. ¿Qué es la globalización? Barcelona: Paidós, 1998. (p.122-123, nota de rodapé). Tradução Livre.

6 "Para nossos propósitos basta admitir que uma formiga pode ser comparada a um agente aleatório, ou seja, um ser que realiza ações erráticas, perfazendo percursos intrincados sem nenhuma finalidade aparente, em suma, um caminhante embriagado que vive ao sabor dos encontros e não manifesta nenhum objetivo definido e previamente traçado. De fato, se observamos os movimentos de uma formiga isolada, não nos é possível discernir nenhuma determinação em seus trajetos sempre ziguezagueantes. As formigas, quando solitárias, parecem invariavelmente estar bêbadas... Mas algo de curioso acontece quando essa formiga dá de encontro com uma fonte de alimento. Subitamente alerta, ela toma uma amostra do alimento e refaz o percurso patentemente errático que realizou até ali (graças a uma trilha química de feromônios que deixou no solo), de volta ao formigueiro. Uma segunda formiga percebe que a primeira porta uma amostra do alimento e procura avaliar seu valor com as antenas. Convencida, a segunda formiga realiza então uma operação notável: divide o mundo em dois hemisférios - a região de onde ela mesma estava vindo e a região de onde a primeira formiga provinha - e põe-se a explorar a metade do mundo à qual a primeira formiga parecia pertencer. Uma terceira repete o processo de divisão do mundo em dois. A cada nova formiga, o processo se reitera e se acumula, de tal maneira que, por volta da ducentésima ou trecentésima formiga, verificamos estar traçado um caminho único que liga o formigueiro à fonte de alimento - e esse caminho é matematicamente o mais curto e, portanto, energeticamente o mais econômico. O que constatamos desse experimento é que uma formiga isolada se comporta como um bêbado sonso - mas duzentas formigas são capazes de resolver um complexo problema de otimização de recursos. A partir da reiteração das ações estupidamente simples de cada formiga - surge um conjunto cuja eficácia e funcionalidade são claramente reconhecíveis. Há, portanto capacidades na ação coordenada de duzentas formigas que não estão presentes nas formigas individuais; um predicado novo foi acrescentado, uma nova qualidade emergiu." Novaes, Adauto. O Homem-Máquina. A ciência manipula o corpo. São Paulo: Cia das Letras, 2003. (p.144-145).

${ }^{7}$ A obra de divulgação de Steven Johnson trata de engenharia de sistemas auto-organizáveis, estabelecendo diversos paralelos entre o mundo biológico e cultural, comparação sabidamente frágil, mas criativa. O livro também traz uma breve história dos sistemas emergentes e de autores que teriam pensado seus objetos por meio dessa ótica, tais como Friedrich Engels e Jane Jacobs. Johnson, Steven. Emergence: The connected lives of ants, brains, cities, and software. Nova York: Scribner, 2001.

${ }^{8} \mathrm{O}$ uso do conceito de esquizofrenia, aqui, não se refere apenas à apropriação que Deleuze faz, mas ao conceito clínico mesmo, de maneira metafórica, tal como Bateson trabalha. Trata-se de uma contradição comportamental que nega a própria significação da negação, de maneira a romper com qualquer encadeamento lógico: “A diferença (da esquizofrenia) em relação à normalidade consiste na consistência do comportamento do esquizofrênico e nos extremos nos quais ele cai. $\mathrm{O}$ esquizofrênico não apenas nega que ele diga algo, mas o faz de tal maneira, que sua negação é negada. Ele não utiliza apenas outro nome diferente do seu, mas um - por exemplo, Stalin - que claramente não é o seu ou que nega sua negação de uma outra maneira. Nas situações em que o normal nega o que diz de forma congruente, o esquizofrênico expressa incongruência também neste plano." Haley, Jay. A interação de esquizofrênicos. IN: Bateson, Gregory et alii. Schizophrenie und Familie. Frankfurt am Main: Suhrkamp, 1984. (pág.84-97). Do original: An Interactional Description of Schizophrenia. Psychiatry, vol.22 (1959), (pág.321-332). Tradução de Ciro Marcondes Filho. Em: www.eca.usp.br/nucleos/filocom/traducoes.html

9 "É preciso determinar a que estrutura social corresponde uma dada estrutura lingüística e como é que, de maneira geral, as transformações de estrutura social se traduzem em transformações de estrutura lingüística”. Kristeva, Julia. História da Linguagem. Lisboa: Edições 70, 1994. 
${ }^{10}$ Tal como Habermas entende a razão última da Comunicação, a qual Luhmann vai afirmar o exato contrário. Apesar desse célebre e fecundo debate, foi provavelmente Edgar Morin o primeiro autor a questionar o ingênuo atrelamento da comunicação ao entendimento. Sobre Luhmann, ver: Luhmann, Niklas. A Improbalidade da Comunicação. Lisboa: Veja, 1992. Sobre Habermas, ver: Habermas, Jürgen. Consciência moral e agir comunicativo. Rio de Janeiro: Tempo Brasileiro, 1989. Sobre a comunicação como fonte de integração social: "Os tipos de interação distinguem-se, em primeiro lugar, de acordo com o mecanismo de coordenação da ação; é preciso saber antes de mais nada, se a linguagem natural é usada apenas como meio para transmissão de informações ou também como fonte de integração social. No primeiro caso, trata-se, no meu entender, de Agir Estratégico, no segundo, de Agir Comunicativo". Habermas, Jürgen. Pensamento Pós-Metafísico: estudo filosófico. Rio de Janeiro: Tempo Brasileiro, 1990. (p.71). Ciro Marcondes Filho analisa o debate: "Javier Nafarrate comenta a posição de Luhmann: 'Habermas, então, vê a comunicação (a ação comunicativa) como processo de entendimento intersubjetivo que se orienta para um consenso racional. O entendimento converte-se, assim, em um conceito normativo. Se, ao contrário, apreende-se a comunicação, no sentido de Luhmann, como um processo auto-referencial, então fica incluído tanto o consenso como o dissenso. Pode-se comunicar que se chegou a um consenso sem que com isso aqueles que participaram da comunicação tenham se aproximado, já que cada um dos sistemas psíquicos permanecem autoreferencialmente fechados. Com isto, Luhmann descarta que a comunicação tenha como constitutivo uma qualidade normativa: 'Não se pode esperar que mediante a comunicação melhore-se a integração dos indivíduos, sua mútua transparência ou a coordenação de suas condutas. Ao contrário, não é nada improvável que quanto mais comunicação, tanto mais se desfaçam os contornos entre vida e consciência dos seres humanos. Sob tais condições é compreensível o desesperançador que é tentar normatizar a comunidade dos indivíduos mediante um consenso de condições ideais'.' Luhmann, Niklas. Die Wissenschaft der Gesellschaft. Frankfurt: Suhrkamp, 1990. (p.22). IN: Luhmann, Niklas. Introducción a la teoría de Sistemas. México: Universidad Iberoamericana, 1996. (p.112). Lyotard reforça [a opinião de] Luhmann: 'não parece possível, nem mesmo prudente, orientar, como faz Habermas, a elaboração do problema da legitimação no sentido da busca de um consenso universal em meio ao que ele chama de Diskurs, isto é, o diálogo de argumentações'. Lyotard, Jean-François. $O$ pós-moderno. Rio de Janeiro: José Olympio, 1986. (p.118). É curioso que Lyotard se opõe também a Luhmann, dizendo que a causa de Habermas é correta (colocar o Diskurs como o último obstáculo oposto à teoria do sistema estável), não os argumentos. Cabe, segundo ele, chegar a uma idéia e a uma prática de justiça separada do consenso, pelo menos do consenso como metaprescrição. O consenso deve ser local, 'obtido por participantes atuais e sujeitos a uma eventual anulação (idem, p.119)." APUD Marcondes Filho, Ciro. O escavador de silêncios - formas de construir e desconstruir sentidos na Comunicação. São Paulo: Paulus, 2004. (p.490).

${ }^{11}$ Deleuze entende essa transformação nos elementos (corpos) da língua como algo interior à própria enunciação: "Existem variáveis de expressão que colocam a língua em relação com o fora, mas precisamente porque elas são imanentes à língua". Deleuze, Gilles \& Guattari, Félix. Mil Platôs - Capitalismo e Esquizofrenia. São Paulo: Editora 34, 2000. Vol.2. (p.20-21). Ou seja, trata-se de formações não exclusivas à língua, de um agenciamento cuja produção não é necessariamente linguagem, tal como fica mais claro nas quatro páginas seguintes: "Não podemos nos ater a uma dualidade entre as constantes como fatores lingüísticos, explícitos ou explicitáveis, e às variáveis como fatores extrínsecos não-lingüísticos. Pois as variáveis pragmáticas de uso são interiores à enunciação, e formam os pressupostos implícitos da língua".

${ }^{12}$ Sobre essa trucagem entre imaginário e linguagem nas "fantasias verbais", ver o capítulo Fantasia: um bate-papo comigo mesmo (ou com ninguém). A esse respeito, vale também anotar a observação de Christoph Wulf: "A fantasia é uma das capacidades humanas mais enigmáticas. Fantasia abrange a capacidade de perceber imagens, mesmo quando a coisa representada não está presente. Caracteriza a capacidade de ver interiormente. Fantasia, imaginação e capacidade imaginativa são três definições da capacidade humana de assimilar imagens de fora para dentro, portanto de transformar o mundo exterior em mundo interior, assim como a capacidade de criar, manter e transformar mundos imagéticos interiores, de origem e significados variados" e segue: "Cornelius Castoriadis define a relação entre os dois mundos da seguinte forma: 'O imaginário deve usar o simbólico, não apenas para se 'expressar', mas para 'existir', para se tornar algo que não seja mais apenas virtual. O simbolismo pressupõe a capacidade imaginativa (capacité imaginaire), pois baseia-se na capacidade de ver em uma coisa uma outra, ou: ver uma coisa diferente do que é. Trata-se da capacidade elementar e irregressível de evocar uma imagem'. Na visão de Gehlen, a fantasia desempenha um papel tão central que o ser humano 'seria mais corretamente designado como ser da fantasia do que como ser da razão'. Apesar de todas as diferenças no ponto de partida e na argumentação, as posições de Gehlen e Castoriadis são idênticas em sua maneira de compreender o imaginário como uma força coletiva, que gera sociedade, cultura e individualidade." Wulf, Christoph. Imagem e Fantasia. Conferência promovida pelo SESC, São Paulo. Tradução: Tereza Maria Souza de Castro. Disponível em: http://www.sescsp.org.br/sesc/images/upload/conferencias/115.rtf. Esse entendimento da fantasia como um fluxo embrionário, gestacional e essencialmente criativo, é parelho ao entendimento que Bergson teve ao analisar a fabulação, diferenciando-a da simples imaginação. Essa seria uma faculdade distinta, visionária e que permitiria a criação de personagens gigantes ou anões; unicórnios - potências que não são personalizadas ou humanizadas, são semipessoais, não necessariamente humanas. Bergson lembra ainda que tal potência é inicialmente praticada nas religiões, mas rapidamente se estende livremente pelas artes e pela literatura. Ver a esse respeito: Bergson, Henri. Les deux sources de la morale et de la religion. Paris: PUF, 1997.

${ }^{13}$ Utilizar aqui o conceito de ideologia talvez seja uma confusão de devesse ser evitada. Não se trata da concepção marxista de ideologia, de um sistema de idéias que reflete as dominações de classe, consubstanciando-se na visão unilateral de que a infraestrutura (economia) determina em última instância a superestrutura (cultura), subsumido o sentido, assim, a forças de estabelecimento e sustentação do poder, sistematicamente assimétricas. Na medida em que trabalhamos com uma concepção gestacional de sentido, não faria qualquer sentido trabalhar com essa interpretação marxista de ideologia, de um sentido a serviço do poder. Nem é, tampouco, a definição esparsa de ideologia que vem se tornando corriqueira nos estudos 
comunicacionais, provindas dos estudos de Análise do Discurso (sobretudo Pêcheux e demais matrizes francesas) e de conceitos que orbitam ao dialogismo de Bakhtin, onde a ideologia é entendida como uma produção de discursos cujas amarras e vícios de expressão evidenciariam seus lugares de enunciação, ou seja, as condições materiais que o suposto sujeito fez uso para determinada aferição de sentido. Fundamentalmente, essa concepção ainda trata de condicionar determinadas práticas a determinados discursos, no mais das vezes, diagramando esquemas para falas de poder e identificando-as no inefável da dimensão simbólica. Seria mais pertinente nos remetermos ao conceito de ideologia em Barthes que, mesmo sem contornos muito precisos, se refere à ideologia não como uma suposta distorção cultural ou uma mágica sinistra da produção simbólica, mas como conjunto de valores que são funcionalizados por meio de um mito, de uma estória contada cujas fendas podem evidenciar sua lógica neurótica. Ver a respeito: Barthes, Roland. O óbvio e o obtuso. Rio de Janeiro: Nova Fronteira, 1990.

${ }^{14}$ Deleuze, Gilles \& Guattari, Félix. Mil Platôs - Capitalismo e Esquizofrenia. São Paulo: Editora 34, 2000. Vol. 2. (p.17). E complementam esse trecho, em nota de rodapé, desta maneira: "Bakhtine e Labov insistiram, de duas maneiras diferentes, no caráter social da enunciação. Dessa forma, eles se opõem não apenas ao subjetivismo, mas ao estruturalismo, dado que este remete o sistema da língua à compreensão de um indivíduo de direito, e os fatores sociais, aos indivíduos de fato enquanto falantes". Na página 45, complementam: "Não há como distinguir, portanto, uma língua coletiva e constante, e atos de fala, variáveis e individuais. A máquina abstrata é sempre singular, designada por um nome próprio, de grupo ou de indivíduo, ao passo que o agenciamento de enunciação é sempre coletivo, no indivíduo como no grupo".

15 "Pode-se conceber um centro como uma força endógena, interior à máquina, que se desenvolve por irradiação circular em todos os sentidos, tomando todas as coisas em sua rede, um mecânico saltando constantemente de um ponto a outro, de um círculo a outro. Define-se, então, um regime em que o ‘signo' não pára de reenviar ao signo, em cada círculo e de um círculo a outro, conjunto de signos reenviando si mesmo a um significante móvel ou a um centro de significância; e onde a interpretação, a determinação de um significado, não cessa de atribuir o significante, como para recarregar o sistema e vencer a entropia." Deleuze, Gilles. A informática, o ruído, a redundância. IN: Deleuze, Gilles. \& Parnet, Claire. Diálogos. Paris: Flammarion, 1996. Tradução de Ciro Marcondes Filho.

${ }^{16}$ Esquizo e, quiçá, paranóica, na medida em que - como assinala Deleuze sobre os índios Hopi - o signo salta de um círculo a outro, ou de um signo a outro em duas espirais. Mas a paranóia pode confortavelmente se instalar quando essa dinâmica passa a ser regida ou regulada por rituais pré-significantes e por toda uma burocracia que decide sobre a legitimidade dos usos. Ocorre quando não se pode mais saltar de qualquer jeito, sem regras, quando os saltos são regulados e as proibições se instalam. Deleuze indica como exemplos dessa máquina paranóica a impossibilidade de ultrapassar um círculo mais exterior ou o impedimento em se aproximar de um círculo mais central. Essa possibilidade se instaura quando os componentes circulares são impossibilitados de efetuarem determinadas correlações, quando o rizoma entre os círculos de signos é proibido. 17 "Virgínia Woolf afirmava que as únicas conversas que valiam a pena eram aquelas onde nunca se acabava uma frase e todos sabiam o que se queria dizer. Tem muito a ver com empatia, com um sentido de compreensão partilhado." Turkle, Sherry. $O$ Segundo Eu - Os computadores e o espírito humano. Lisboa: Presença, 1989.

${ }^{18}$ Deleuze, Gilles. Proust e os Signos. Rio de Janeiro: Globo, 1981. (p.155-156).

${ }^{19}$ São essas trocas entre os nicks que em última instância formam a categoria de sentido aqui entendida. E isso dá a medida da impossibilidade de se remeter um circuito - cujo sentido não está na remissão individual - a uma frase ou um discurso. Esse sentido é, pelo contrário, uma membrana que se forja envolvendo o ambiente, tomando forma e circunscrevendo as falas dos agentes. Esse sentido deve ser desenhado como um círculo que envolve e é cruzado por uma infinidade de linhas, e não como uma reta vigorosa. Pois dizer que esses agentes produzem um discurso é, em última instância, equivocado. Seriam antes "cartadas", tiros ou entradas (como entende a programação de software) em que o sentido de uma oração se vincula menos às anteriores e posteriores que à própria vontade de representação que ela guarda em si mesma, sozinha e impotente. Talvez o termo francês enjeu (aquilo que está sendo apostado, o cacife), seja mais fiel a um ato expressivo cujo objetivo último guarda mais a despretensão e o desinteresse pelo virtus, próprios a uma dimensão trágica, do que o imperativo de significar uma transcendência que todas as assunções da semiologia invariavelmente carregam. Nessa dimensão, não há nenhum projeto, nenhuma transcendência, mas apenas apostas, enjeus.

${ }^{20}$ Para uma compreensão mais ampla sobre as "atrações estranhas" no fenômeno comunicacional, ver o conceito de "Atrator Estranho" debatido pelo extinto Centro de Pesquisas em Novas Tecnologias, Comunicação e Cultura, que pode ser encontrado em: http://www.eca.usp.br/nucleos/ntc/ntc.htm, sobretudo na Revista Atrator Estranho editada pelo mesmo grupo.

${ }^{21}$ Deleuze, Gilles. A informática, o ruído, a redundância. IN: Deleuze, Gilles. Diálogos. Paris: Flammarion, 1996. (pág.137139). Tradução de Ciro Marcondes Filho.

${ }^{22}$ Bey, Hakim. TAZ: Zona Autônoma Temporária. São Paulo: Conrad, 2001. (p.76-77).

${ }^{23}$ Idem, (p.76-77).

${ }^{24}$ Shank, Gary. Abductive multiloguing: the semiotic dynamics of navigating the net. The Arachnet Electronic Journal on Virtual Culture, Vol. 1, 1993. Disponível em: www.ibiblio.org/pub/academic/ communications/papers/ejvc/SHANK.V1N1

${ }^{25}$ No original: "But the linguistic models of lecture, dialogue, discussion, and even text (the written model of communication) do not capture the dynamics of sign usage that characterizes Net communication. A new linguistic model is needed. Let me briefly suggest a model of sign communication that might describe Net communication. I call it the multilogue." Idem.

26 "A comunicação na Internet inclui uma infinidade de agentes. Há aquele que inicia a conversa - o emissor inicial - que dá início à seqüência de intervenções que no final constituirão uma corrente de mensagens (thread). Um thread, como os especialistas em computação entendem o termo, é uma série de mensagens intercambiadas por computador que iniciam com um assunto particular mas que pode tomar direções muito diferentes antes de a discussão terminar. Uma vez que um thread tenha começado, entretanto, ele não está mais sobre controle. Isso porque o mecanismo de resposta da Internet não requer a troca de turnos na comunicação". No original: "Internet communication starts with a number of players. There is the starter, or 
the initial sender, who begins the sequence of communication that is eventually called the 'thread'. A thread, as the computer literati use the term, is a series of computer-generated communications that start on a particular topic but that might lead in many different directions before the discussion is done. Once a thread has been started, though, it is no longer under sender control. This is because the mechanics of Internet response do not require turn taking." Shank, Gary \& Cunningham, Donald. Mediated Phosphor Dots: Toward a Post-Cartesian Model of CMC via the Semiotic Superhighway. IN: ESS, Charles. (org.) Philosophical perspectives on computer-mediated communication. New York: State University of New York Press, 1996.

27 "Gary Shank e Don Cunningham usam a semiótica como estrutura teórica para compreender a Comunicação Mediada por Computador (CMC). Eles argumentam que a combinação única de dimensão oral e textual na comunicação da Internet foge às assunções e categorias da teoria consolidada. Oferecem então o conceito de multiálogo (em contraste com o monólogo ou o diálogo), exemplificado em uma corrente de mensagens iniciada por uma pessoa que rapidamente se desenvolve por meio das respostas de inúmeras comunicações, como mais apta para dar conta dessas novas formas e sujeitos da comunicação". No original: "Gary Shank and Don Cunningham take up semiotics as a theoretical framework for understanding CMC. They argue that the unique combination of oral and textual dimensions of communication on the Internet escapes the assumptions and categories of earlier theory. They offer Shank's notion of a 'multilogue' (in contrast with a monologue or dialogue), exemplified in a message thread initiated by one person and then rapidly developed through the responses of any number of communicants, as better able to account for these new forms of communication and communicative subjects." Ess, Charles (org.). Philosophical perspectives on computer-mediated communication. New York: State University, 1996.

28 "O receptor está imerso no processo comunicativo de uma maneira que os pontos de fósforo, e mesmo as palavras que eles formam, deixam de ser interessantes em si e para si mesmos, para se tornarem um poderoso sistema semiótico constantemente emergente, no qual o participante é a chave mas certamente não o único componente". No original: "The receiver is immersed in the communicative process itself and that the phosphor dots, and even the words they form, cease to be interesting in and of themselves but become a powerful and always emerging semiotic system of which the participant is a key, but certainly not the only, component." Shank, Gary \& Cunningham, Donald. Mediated Phosphor Dots: Toward a Post-Cartesian Model of CMC via the Semiotic Superhighway. IN: ESS, Charles. (org.) Philosophical perspectives on computer-mediated communication. New York: State University of New York Press, 1996.

29 "Se há linguagem, é antes entre aqueles que não falam a mesma língua. A linguagem é feita para isso, para a tradução, não para a comunicação." Deleuze, Gilles \& Guattari, Félix. Mil Platôs - Capitalismo e Esquizofrenia. Vol.3. São Paulo: Editora 34, 2000. (p.119). 
Esta língua não é minha, qualquer um percebe. Quando o sentido caminha, a palavra permanece. Quem sabe mal digo mentiras, vai ver só minto verdades. Esta não é minha língua. A língua que eu falo trava uma canção longínqua, a voz, além, nem palavra. $O$ dialeto que se usa à margem esquerda da frase, eis a fala que me lusa, eu, meio, eu dentro, eu, quase. Paulo Leminski ${ }^{1}$

O céu sobre o porto era da cor de uma $T V$ sintonizada num canal morto Willian Gibson ${ }^{2}$

Desconexo porque não sei quem o ordena; não pode ser comunicado porque é intangível, e pelo mesmo motivo exige ser comunicado.

Franz Kafka ${ }^{3}$

Constata-se como os aparelhos se preparam para programar as nossas vidas: como o pensamento, o desejo e o sentimento vão adquirindo caráter de jogo em mosaico, caráter robotizado; como o viver passa a alimentar aparelhos e ser por eles alimentado. O clima de absurdo se torna palpável. Aonde, pois, o espaço para a liberdade? Vilém Flusser ${ }^{4}$ 
Nessa tradição, não é a linguagem que concentra a operação de corte e de sentido, ela nada comunica na tradição grega segundo a leitura de Heidegger. A desgastada ferramenta "linguagem" esteve sempre aquém, espécie de faca sem corte na perfuração do signo, pois o processo todo escapa à dinâmica fechada entre significante/significado. Não se resume o sentido a um construto teórico externo e acabado, pois a alquimia sígnica ocorre dentro do próprio signo, e não em um exterior a que se possa remeter. Piorando, essa interioridade guarda uma complexidade expansiva, não-delimitável, e quanto mais a qualificamos e precisamos, mais elas crescem e as perdemos de vista: quanto mais clico, quanto mais converso, mais percebo que o intuito de tocar o sentido disso tudo é enganoso, fantasmático. O morfema gramatical não se confunde com o que se poderia chamar o morfema de expressão. Há negações que confessam. O sentido está além da letra, o sentido é sempre irônico. ${ }^{7}$

E esse sentido não é tampouco transcendente ao objeto. É imiscuído, parcial e traiçoeiro. Parte nele e parte em nós, observadores. Se a atual liquidez contemporânea que fragmenta e fractaliza os objetos ajuda a enterrar antigos consensos da razão, ela também insiste em acepções para o sentido desprovidas de capacidade explicativa. Daí a dificuldade em se trabalhar a falta de sentido nas relações sociais, pois ainda que redimensionadas pela teoria, esse sentido é já um outro. E não há uma teoria a que possamos nos remeter como método, pois nem mesmo a atenção flutuante da psicanálise - espécie de estrutura organizadora que opera maneiras de entender os feixes desordenados do sentido, como nos sonhos possibilita essa apreensão de sentido.

Essa fratura na concepção mesma de linguagem - em sua definição que crê envolver a comunicação qualifica os chats como uma modalidade fértil para entender a correlação entre modalidade discursiva e agenciamento subjetivo. Isso porque como se viu nos capítulos anteriores, a categoria do sujeito, centrado e edipiano, é fundamentalmente moderna; a linguagem, elemento que lhe serve de aporte estrutural, está necessariamente atrelada às mesmas junções. $O$ desmontar de um é também o desmoronamento do outro. Paralelamente, se a família nuclear é reformulada ou relativizada em sua importância, é natural que a relação com o "Outro" e com o "outro" do corte simbólico seja também deslocada. E se realmente existem modelos não-triádicos de fabulação e produção de subjetividade, é natural que maneiras de se comunicar e de nomear experiências diversas também ganhem atualização. A linguagem carne cor de plástico trata precisamente dessa esquizofrenia de significações que são atravessadas por um fluxo escorregadio e singular, em muito diferente da categoria estanque que a semiologia guardou para este termo: o sentido.

Por isso, vale se remeter ao conceito fenomenológico, algo bizarro e algo velhaco, de carne, na medida em que viabiliza a apreensão do acontecimento sem uma apreensão empirista imediata, de um lado, nem 
transcendental, de outro. A carne é o substrato último onde opera a epoché e isso deve bastar, reza Maurice Merleau-Ponty, lembrando que a carne não é uma substância, não é nem matéria nem espírito. Seria o caso de se pensar na carne como elemento, atributo de coisa geral, tal como os elementos terra, fogo, ar e água. Carne indica um estilo que conjuga partículas indiferenciadas de um lugar qualquer. Não se fica na carne, mas a carne está no ser fazendo do nosso corpo uma forma de vida. A carne é o híbrido arranjo de sentido entre elementos materiais ordenados estilisticamente.

É esse entendimento da "carne do mundo" que pode ajudar a encontrar uma porta aberta nesse modo de comunicação, que não é linear nem segue as premissas da circulação de informação. É antes espectral, é feito por um círculo que envolve uma infinidade de emissões e recepções, cruzando-lhe o interior. O problema é que o sentido dessa comunicação não está nas emissões ou nas recepções, nem tampouco no virtual entendimento abstrato que advém da troca. O sentido é o círculo, é o ambiente onde a comunicação se desenvolve. É a imanência que subjaz às trocas comunicacionais, sem no entanto se definir por elas. Mas não vale a pena tentar tocar na carne: nada se acha.

Muitas vezes não entendi nada do que li nos chats. Presenciei até o cansaço, naquelas madrugadas vazias que não tem relógio, a sucessão interminável de frases absurdas: qual sentido? Foi só o cansaço que indicou que não se devia procurar o sentido por ali. Vale mais percepcionar o treinamento de uma língua menor, pois sentido é assunto de devires, minorias e experimentalismos. Envolto naquela massa indistinta de usuários, esvaziando e esgotando a palavra, havia uma língua outra sendo permanentemente tentada, fracassando na maioria das vezes, todas as vezes. Quando brincavam com a própria língua brincavam com a semiose estabelecida que herdaram. Queriam, obcecados pelo sentido, estuprar o significante: devemos ser bilíngües mesmo em uma única língua, devemos ter uma língua menor no interior de nossa língua, devemos fazer de nossa própria língua um uso menor. ${ }^{8}$

Eles criam fontes tipográficas e inventam alfabetos. Eles enxergam o espaço por meio de pontos, linhas. Eles esquadrinham as cidades horizontal e verticalmente. Alteram as distâncias, os ritmos, as proporções. Comprimem e expandem ondas sonoras. Nada fixo, nem sequer uma matriz. Pixel por pixel, dilatam a paisagem até as margens do monitor. Subvertem os objetivos bélicos do videogame. Eles têm o poder de realinhar o mapa geopolítico em um minuto. Chegaram os hackers que atuam dentro da arte. ${ }^{9}$

O que sustenta a invenção de um novo sistema de expressão é então o empurrão dos sujeitos falantes que querem fazer-se compreender e que retomam como uma nova maneira de falar os restos gastos de um outro modo de expressão. A língua é toda acaso e toda razão porque não existe sistema expressivo que siga um plano e que não tenha sua origem em algum dado acidental. ${ }^{10}$

Os chats não podem, não querem, e não precisam ser reais. Isso é importante na medida em que seu universo de aparências monta-se ao gosto do signo, que é constantemente revertido por meio de assaltos 
semióticos. A própria aparência, vale lembrar, não é apenas subproduto do real e das faces do ser, é estratégia deste real e deste ser. A aparência manipulada é, por decorrência, o real e o ser manipulados. Um chat quer manipular toda a semiose, sem o saber. Funciona como um imenso jogo de modelagem da aparência: a sedução nunca está na carne do corpo, mas nos contornos, nos perfis, nas desmontagens.

E como foi visto no capítulo A sedução do texto estranho, é possível concatenar verdade e mentira de maneira não contraditória, dimensionadas em um contexto que relativiza a lógica linear aristotélica, dedutiva e analógica. A maneira algo bizarra com que a produção sígnica é trabalhada nesses ambientes de interação - na perspectiva que aqui falamos - remonta a uma dinâmica de significações nãolingüísticas, e se possível fosse, a um signo selvagem, um signo comunicacional.

Encontra-se na literatura de Borges múltiplas camadas de sentido em uma mesma estória, manobradas por um estilo narrativo em que o assunto abordado não é, curiosamente, mais importante para o conto do que a estrutura lógica da própria narração. É como se Borges trabalhasse com a linguagem de uma maneira em que as fraturas de sentido na estória contassem, paralelamente, outras estórias também. Seria como uma confissão que diz que o código utilizado para escrever é passível de uma utilização que trai o “reino das palavras"; uma manipulação no nível mais "baixo" da língua, como diria algum programador.

Seus jogos de palavras, jogos de tempo, jogos de existências, são truncados e repletos de paradoxos. Em Borges, a existência e a não-existência confundem-se porque não são tecidos como elementos forçosamente contraditórios, mas por uma recursividade lúdica que segue a coerência de uma brincadeira. Nos mundos que criou, os habitantes não guardam uma importância adequada à narrativa convencional, com lugares definidos, marcando certas funções a serem exercidas dentro da obra e condicionados por uma significação convencionada. Inversamente, abundam variáveis que fazem a significação ser algo permanentemente incerto, pois os arranjos e a coesão da história são deslocados por efeitos de sentido dinâmicos: a obra se desmancha continuamente. Talvez fosse o caso de se perguntar se Borges deseja, efetivamente, contar alguma coisa: o próprio fato de recontar histórias ou reescrevê-las indefinidamente, bem como a premissa de que toda estória já foi escrita, são sinais claros de que sua preocupação não é exatamente essa. Não é, melhor dizendo, um esvaziamento da estória, mas algo próximo daquilo que Barthes chamava por “trapacear a língua”, burlar o fascismo inerente à linguagem.

Essa maneira peculiar de escrita funcionou porque o escritor percebeu a fragilidade mais traiçoeira da linguagem: a de que toda significação é virtualmente equívoca, é um construto que flutua entre eixos de polaridades instáveis e cujos sinais podem ser invertidos, alterados, bastando que se domine o acento nela impresso e assim subvertendo toda a lógica simples de recados morais e desígnios éticos. Trata-se da percepção trágica de que, se não existe receita última sobre a feitura do material humano, não pode 
haver igualmente um espelhamento único, mas modalidades de jogar uns com os outros, compor e recompor afetos de maneira desajuizada. Não deixa de ser salutar o receio borgeano de entrar de modo excessivamente direto nas coisas, pois o risco, sabe-se, é de estragar o sentido, aquilo que só as nuanças entre lógicas distintas produzem.

É mais do que apenas "trapacear a língua", é perceber que não existe controle último sobre o sentido. Borges apenas se rende à produção interminável de sentido que o próprio texto produz e que nunca está sobre seu controle, regozijando-se conscientemente desse handicap. Inversamente, os chats produzem esse sentido espectral sem que seus participantes se apercebam dessa condição. São absorvidos pela megamáquina geradora de um texto autônomo de múltiplas entradas e inúmeras leituras.

Por isso, ao fazermos um perscrutar dessa linguagem, nos incubamos em seu caráter alegórico, nos desviando da suposta centralidade e autonomia do discurso. É uma operação que aceita a presença do sentido da narrativa em outro lugar que não em sua semiose, talvez mesmo além das possibilidades de enunciação. As relações entre significante e significado podem aparentemente ser desprovidas de sentido, pois suas articulações se costuram freqüentemente em relações paradoxais. A circulação espiralada de sentidos guarda a tessitura social dessas relações entre indivíduos, nicks e bits. Sua constituição é de uma carne toda plástica e colorida, objeto cuja apreensão tem que estar fora do primeiro plano do foco ${ }^{11}$.

\section{FENOMENOLOGIA DA LINGUAGEM CARNE}

Do ponto de vista fenomenológico, podemos definir esse processo de cognoscibilidade por princípios que se desviam da ortodoxia científica ou da cartilha funcional e positivista. A idéia é fugir da abordagem cientificista e, sub-repticiamente, de sua sempre companheira separação entre sujeito e objeto. A apreensão pela epoché, a redução que resume o ato de apreensão "pura" e "visceral" do objeto pode soar algo inefável, talvez até místico. Mas o conceito de intencionalidade, jargão-resumo de todo uma escola, reaparece como luz perdida frente às respostas lusco-fusco que o método, nestes dias confusos, teima em apresentar.

A abordagem fenomenológica alude a uma aceitação dos objetos dentro de uma globalidade de significados autônomos, onde mesmo as particularidades não constituem pistas à somatória de contextos ou filiações. Essa operação libera os objetos das indefectíveis matrizes de significante, de memória, de tradição e mesmo de referência tão usuais às ciências sociais. O deslocamento do foco metodológico se faz na medida em que o abismo entre sujeito e objeto é substituído por uma idéia de conjunção, de copertencimento $^{12}$. Se a máxima que diz que não se pode escrever sobre aquilo de que não se fez parte é já 
um clichê, sua acepção radical enquanto veio metodológico não o é. Sujeito, assim, deve ser também um objeto histórico e científico em si mesmo, e ao mesmo tempo. Não se trata de uma observação participante, ou de relatos de experiência, mas de ser e devorar os bifes invisíveis da "carne do mundo".

Para tanto, é preciso uma implosão no conceito de corpo da fenomenologia enquanto se mantém o uso da epoché, num estratagema que problematiza os inputs e outputs da percepção. Como se pudéssemos fazer uso de uma argúcia e sensibilidade exacerbadas, delirantes, sobre flexões singulares do objeto, espécie de método sem fora, sem remissão externa. Então, lá no olho do furacão desse sonho privativo que é um chat, evitar submeter os pontos de não-sentido à sujeição de uma hermenêutica, do império interpretante. Trata-se de deixá-los procriar, amplificando-se para então cultivar outras formações imaginárias, junção tencionada de idéias e de personagens. Se o roteiro da hermenêutica científica não seguisse um padrão, então as sobrecodificações poderiam ser remanejadas e recombinadas até se atomizarem, virando um outro. O acontecimento, aqui, é o engendrar de processos criadores que subvertem o marasmo das significações estabelecidas. Essa língua de plástico quer ser mutante porque sua matriz geradora, a subjetividade, também o é.

É por isso que o método não é um caminho. A dinâmica que se estabelece nesse tipo de objeto é aquela dos acontecimentos imprevisíveis. Baudrillard gostava de dizer que a única saída era posicionar um projetor contra estes fenômenos, esperando que se deixassem apanhar. Quer com isso dizer que a possibilidade de sermos maiores ou mais "espertos" que o objeto é minúscula e irrelevante, que sempre dependemos da sorte pura $^{13}$.

De maneira semelhante, parece-nos que a possibilidade de perscrutar essa máquina de geração de texto não pode ser diretiva, assertiva e indagadora. Não posicionamos telescópios nem armadilhas à realidade, mas a rasteamos com faro e pegadas: esse método não fotografa nem congela, ele corre atrás para viver junto. Linguagem carne cor de plástico é meramente a canhestra tentativa de trazer a imanência desse medium para dentro deste outro medium, que é esta escrita acadêmica. Na verdade, não se trata de importação, trata-se de uma controversa combinação de técnicas ${ }^{14}$.

A linguagem cor de plástico não vai provar nada, não vai encontrar nada. Pode apenas indicar, inadvertidamente, alguma rota ou eventual desvio sucedido. O retraimento dessa máquina de geração de textos é tamanha, que não é possível um conhecer estrutural ou estruturado: denega-o na sua interminável versatilidade avessa a análises. Só posso, na verdade, fazer uso da minha experiência. Não porque seja verdadeira, porque seja privilegiada ou porque seja a mim confiável. Trata-se do justo oposto. A idéia consiste precisamente em ser estranho à sua própria abordagem, fazer com que ela lhe 
seja incompreensível e que por isso mesmo se assemelhe ao objeto. O movimento seguinte, de torná-la apreensível, é por decorrência a operação que decodifica as amarras do objeto ${ }^{15}$.

É então algo como uma espécie de fenomenologia dos movimentos. A razão se dá num continuum, em blocos de sentido imbricados e inextricáveis. Em termos bergsonianos, é encontrar a razão no durante ${ }^{16}$. A próxima cena que está por ser aberta em umfade in:

Então me fecho naquele monitor que se basta a si mesmo. Espiral tautológica onde se vive em pixels de um massacrante gosto de carbono entardecido. Cyber carne moída é o processo de reconstrução fractal de um Eu por colagens recortadas da carne, milimetricamente coladas no monitor. Mosaico de compreensão turva que descansa em abismos incomunicáveis, uma tentativa de remover a fronteira entre sangue e dígito, fazendo do fluxo de informação, fluxo de consciência. Tentativas de interpenetração no visível do texto, no invisível da linguagem ${ }^{17}$. Processo que vai e que vem.

Uma hipnose sensorial completa: imersão. Sincopagem entre diversas cores usáveis, diversas possibilidades de junção na linguagem cor de plástico. Uma vez mais, o Desejo e a Máquina: o plástico cor de carne. Nem mesmo importa se essa carne, moída, é um simulacro, se o sangue é de groselha e se o espelho é especular. Liquidificando Dietmar Kamper: Quem sonha com quem no sonho da máquina, no sonho sonhado pela máquina: não pode ser que ocorram diversos sonhos ao mesmo tempo, com os mais diversos lugares, direções e intenções? E que a atual confusão venha da confusão dos sonhos? ${ }^{18}$

Um transe psíquico, então, engendrando encadeamentos lógicos diferenciados. Sono que gera sonho que gera diferenciação. O corpo é então uma máquina que semiotiza modalidades diversas, talvez mesmo contrapostas. É como se o próprio corpo pudesse, sobre si mesmo, dobrar-se. Isso ao mesmo passo em que os espaços, as paredes e as dimensões desse imaginário também se dobram. Fluxo e corte. Se o cinema hipnotiza, se a cidade descentra e se a organização faz produzir, é o onírico que lhes corta, funde e engravida-os de sentido.

\section{O MANANCIAL DO TEXTO VELOZ}

Quando se abre uma janela de chat, não se recebe um quadro delimitado de texto, como em uma carta. A barra de rolagem, lateral à janela do canal, indica que a conversa se desenrola ininterruptamente. É uma torrente de frases que inviabiliza um feixe que lhe possa delimitar, recortar e enquadrar. Como máquina, sua produção não tem por finalidade determinado conteúdo ou efeito, mas a própria produção ininterrupta ${ }^{19}$. 
Então os chats jorram. Manancial pouco formoso esguichando o desagradável, o absurdo, o insignificante. São canais seriados onde o irrelevante, finalmente, deve ser incluído. Naturalmente, não há muito de normal nesse espetáculo de perturbados. Normalidade e perturbação são, aliás, conceitos que sempre se cruzam, como constatara Freud a respeito das práticas e vivências sexuais normais, e por isso mesmo, de todo perturbadoras.

A frase digitada nem chega a ser tão importante. Significativo é a correnteza de emoções que se forma nas salas. Os lapsos, por sua vez, são a característica primeira de todo um estilo, quiçá de todo o meio. Esses lapsos (in)voluntários são tecidos e compostos pela pulsação singular dessa superfície, e quando parecem finalmente assentar são novamente chutados para o alto. Faz-se uso dos lapsos como se fossem instrumentos de tele-transporte.

Esse modus operandi na produção de um texto não é nenhuma novidade. Não é a primeira vez que o simples acionar de um botão inicia inesperadamente todo um fluxo ininterrupto de texto, de palavras ${ }^{20}$. Kafka já escrevia literatura como quem ativa máquinas de subjetividade mortais, com seus dentes e engrenagens feitos de ferida e dor, a sangrar como só um hemofílico pode fazê- $10^{21}$. Henry Miller e seus herdeiros da geração beat deleitavam-se neste modo de produção subjetiva, otimizando-a até que a prosa virasse, ela também, uma máquina. A novidade é esse modelo de produção sensorial, até então circunscrito ao universo literário, aparecer fundido no mais comezinho medium de comunicação. Suas operações são bastante semelhantes, mas não os resultados.

É uma linguagem em muito afeita ao clipping permanente de sentido. Uma representação gráfica desse fluxo de diálogos indicaria um recortar e colar de frases e coisas, juntando-as. Ao canal, a contingência de mediar a incessante construção de um texto multimodal. A diagramação lógica desse discurso remete a Artaud e sua concepção de escritura como porcaria, pois não há decerto escrita meramente individual, fora da "carne-mundo". É sempre um constante fluxo que simula os canais de ligação de uma linha traçada. Do esperma ao excremento ${ }^{22}$, do codex à história, é uma narrativa costurada mais pelo líquido das pessoas do que por elas mesmas ${ }^{23}$.

No trilhar da hipermídia e do hipertexto, seria então algo como uma hiperficção. Ou algo anterior a isso, pois é um medium que recebe diferentes vozes, textos ou diálogos ${ }^{24}$, coadunados caoticamente no mesmo espaço. Michael Joyce fala deste virtual texto: A hiperficção é como sentar-se num restaurante em meio ao burburinho de histórias, algumas bem conhecidas, algumas de que só se ouviu metade, entre pessoas com as quais compartilhamos apenas a brevidade da vida e a certeza da morte ${ }^{25}$. 
Oceano é a metáfora que mais se aproxima do liso, do não-demarcado. O ciberespaço não consegue, nem mesmo forçosamente, ser como o labirinto em que nos perdemos, para regozijo total dos sentidos. Não vemos a identidade se evaporar no espaço virtual, despedaçando-se em fatais estilhaços. O labirinto como símbolo do ciberespaço, para se perder e se (re)encontrar, veta o que entendemos como mais intrigante na configuração tecnopolítica da grande rede: oceano, um espaço liso e não um espaço estriado. Não se trata de se perder nem de se achar, pois não tem efeito uma dicotomia entre "perderachar" em um espaço que não tem matriz ou centro de referência fixa. Borges, por sua vez, se aproveita dos labirintos não para neles resumir a inteligência humana, mas para ali refletir sobre suas armadilhas, limitações e ingenuidades. O labirinto quer caminhos, ainda que aleatórios e/ou incontáveis, com ou sem Minotauro ou Ariadne. O oceano, por sua vez, já nem precisa essa travessia. Espécie de confusão, massa líquida e modelável de acordo com o receptáculo, sem-saída que pode vir a ser uma passagem original. O zoneamento do oceano é de um domínio caosmótico.

\section{IDENTIDADE COR DE PLÁSTICO}

Outra boa metáfora para o fluxo e influxo do oceano é o universo onírico, o mecanismo de produção dos sonhos. Como sugere Deleuze em sua recusa da tripartite freud-lacaniana, a categoria do Inconsciente é escamoteada por uma massa infusa e sem significação lingüística. Contrariando a exegese lacaniana, o Inconsciente não é organizado pela linguagem porque, simplesmente, não é organizado. Não há um superego a ser suprimido e um ID a florescer, a produção sequer se comunica com a realidade castradora, se muito lhe manda bilhetes. Trata-se, assim, de substancias e velocidades, e não de significados e interpretações. Ou seja, no universo onírico, não há um contorno físico, cultural ou identitário preciso. A bandalheira das esferas psíquicas, agora relegadas a esferas mesmo, não mais se auto-regulam nem apresentam uma relação de "soltura" ou de "pertencimento" umas em relação às outras. Se as questões aqui podem surgir, se as revelações podem aqui ser feitas não é porque o irrevelável se revelou, mas porque o Desejo, ele só, engendrou.

Esse fluir ou fluxo da expressão seria em algo semelhantes ao mecanismo da paixão, porque desenfreados e sem finalidade. Ambos funcionalizam um conjunto de características identificatórias entre o sujeito e um Ego ideal, ou algo que cumpra essa função. Tal processo identificatório, entretanto, pode ser compreendido por dois veios distintos. Na perspectiva lacaniana, ainda é a promessa de saciar a falta indefectível resultante da castração simbólica. Deleuze, por outro lado, ao rechaçar essa concepção primeira de falta e objetar que o Desejo é sempre anterior à falta, indica que a atenção deve repousar não sobre o mecanismo da falta e sua relação objetal, mas sobre certas práticas concretas que criam e que se esquivam da lógica de identificações viciada. Diferentemente do mecanismo de paixão em Lacan, que 
sempre retorna à falta original, esse veio atenta para uma paixão que se faz pela diferença própria ao objeto, ou seja, que encontra nele mesmo sua diferença para com o (lugar do) objeto.

A estrutura hipermidiática revela-nos que a subjetividade não está somente em níveis inconscientes, ou em representações como os matemas lacanianos, está, também, nos grandes discursos sociais e em suas mídias, na História ou na arte. Há algo de maquínico que revela, agora mais do que nunca, a composição estética do inconsciente. $^{26}$

Componentes da linguagem carne cor de plástico: mentira, sonho, devaneio, o incomum, a piada, o lapso, a inibição e o jogo. Todas essas performances inspiram-se nos montantes de identidade disponíveis no supermercado da comunicação. Quando finalmente conseguem soar algo enigmático para as partes interessadas, a comunicação desconcerta. Começa então o mecanismo de alusão, de fantasia, vírus que opera em uma lembrança ou referência de que se é refém. Este mecanismo, da sedução, é traiçoeiro porque embora as pessoas sejam por ele atingidas, nada sabem o que fazer com isso. É impressionante falar e ler diante daquele oceano de nicks concentrados, que não são rostos, estendendo-se até onde a vista alcança. Ou seja, a quatro palmos do nariz. A identificação é um processo algo místico.

O processo de identificação entre participantes parece se costurar sobre o pano de fundo que são as formações culturais. Espreitando as tensões sociais entre formações tão diferentes, a identidade se constrói por meio de um metaprincípio de conexões e filiações. Parece, assim, haver algum princípio que ordena as estruturações e formas de reconhecimento. Seriam como miragens do imaginário, motivadas quiçá pelo mecanismo desejante, talvez pela falta, que marca o término desse desconforto.

A proposição deste capítulo, da linguagem carne cor de plástico, é a de que a relação entre sujeito e objeto nos chats pode servir de guisa para uma reflexão pormenorizada para a não resolvida situação daquele que, tocando, é tocado. Isso porque a ausência de uma imagem entre os interlocutores produz um plano de projeções e idealizações sem fỉm, talvez mesmo sem começo: pura contingência. Não é uma situação de simples virtualização, é antes uma condição de radical espectralização da psique onde a própria alteridade é profundamente simulada, e o corpo, mera representação. Mas como o debate sobre a técnica ensina, um homem sem psique é essencialmente não mais um homem. Paradoxo ontológico?

Não exatamente. O que esse objeto nos força a perceber é que a zona de intersecção entre o sujeito e o objeto nunca ganhou concretude, nem em um, nem no outro. Ela bóia no encontro, no movimento que fundamenta um estado mutante de relações. O foco não pode assim estar nem em um nem no outro, mas flutuante e radicalmente descentrado. Nos chats, a corrente de expressões lingüísticas vai grudando em formações discursivas conhecidas, pré-formatadas, embora o sentido não seja determinado pelo discurso do agente ou do sujeito. Este sentido é na verdade subseqüente, imprevisível, porque está incrustado no 
magma de uma virtualidade que não pode ser delimitada, que é irreconhecível e que, como querem os lacanianos, encontra-se no finito pré-dado do Outro. Seria como a epoché dos fenomenólogos, se fosse possível abolir a centralidade do conceito de corpo e pulverizá-la, expandi-la até que ela mesma pudesse comer o próprio rabo, num looping infinito. O exemplo da fenomenologia, entretanto, é cabal: a intencionalidade não pode ser separada do objeto, pois esse próprio ordenamento é anterior às polaridades da discursividade sujeito-objeto.

Deleuze gostava de martelar que o atual e o virtual não podem ser concebidos como polaridades autoexcludentes. Pelo contrário, são contingências permanentes, que se realimentam e que não existem apartadas uma da outra ${ }^{27}$. Não fazer a separação entre a carne e o plástico, entre o sangue e a simulação, não implica elevar o "falso" à categoria de "verdadeiro", aniquilando-os numa homogeneização redutora. Implica antes em tomar as "realidades simuladas" - oxímoro só em princípio inconciliável - como pedregulhos indeléveis de uma realidade que não se ordena por um estatuto binário de real/irreal, nem por um único plano de validação ou verdade. Não é, então, aniquilação dos conceitos por um nivelamento de cima para baixo. É procurar na ficção a parte que a realidade suprimiu. Essa linguagem cor de plástico é a pulsão ficcional que traz aquele indefinível que fica desejando.

\section{LINGUAGEM SEM ROSTO}

As modalidades comunicacionais da Era Tecnológica são tributárias de uma conformação ultrainformacional, onde o modo de produção econômico se confunde com os media. Mas não se trata da exegese marxista que reza por uma superestrutura determinada pela infra-estrutura, são antes retroalimentações entre as instâncias material e imaterial do corpo social, cujo resultado pode ser tanto dinamismo material quanto crise ou paralisia cultural. $\mathrm{O}$ movimento frenético da produção industrial penetra na escritura informacional da cibercultura, oferecendo um círculo imobilista: quanto mais nos agitamos, quanto mais saímos de um lugar, mais permanecemos aterrados e estáticos, estrebuchando.

A ultra-aceleração não facilita a comunhão com a carne do mundo, a troca direta e efetiva de afecções. Mas por meio de uma repetição sincopada de palavras, as salas de chat reproduzem a velocidade imobilista do mundo, tal como a monótona melodia que uma discoteca nos surra: um grafo que repete e se repete randomicamente, criando um repuxo para fora da massificação expressiva, uma força contraditoriamente libertadora. A repetição se torna seu inverso, compondo uma dualística em que os impasses e enganos do sentir são catalisados por uma reescrita sem fim. 
Por isso não ver os chats como diálogos, mas como estilhaços da subjetividade sendo tecidos diariamente. Pequenos contos, pedaços, detritos de um mosaico a compor a narrativa contemporânea, com diferentes estilos, erros, confusões, pontos de vista, toda uma escritura cibercultural digitada por inúmeros autores. Não há a linearidade retirada de um texto ou de um diálogo. Nada nos chats se desenvolve propriamente porque o personagem é ele mesmo, o medium, que a qualquer momento voltará para o lugar inicial: looping.

Essa inconstância do texto é uma efeméride que a impotência comunicacional comemora diariamente, sem se reduzir a um fenômeno midiático: nesse mundo, as palavras articuladas assemelham-se a bolhas: elas espoucam, se sucedem e se desmancham no ar; a comunicação fica impossível ${ }^{28}$. É uma escritura que corresponde passo a passo ao nosso mundo interconectado, veloz e superficial, a que nos cabe sobreviver entre incoerências e sentidos justapostos. Fulcral nesse processo é a comunicação com a “carne-mundo" se desvincular do olhar, antigo árbitro das mediações humanas.

A artista plástica Marina Bramovic descreveu sua famigerada instalação na Galeria Sean Kelly, em que ficou doze dias totalmente exposta ao público, como uma tentativa insólita de comunicação sem linguagem. Sua entrevistadora, Laurie Anderson, lembra que a linguagem é uma defesa. É causa, distanciamento; é chamada de comunicação, mas freqüentemente não é. Às vezes trata-se simplesmente dessas coisas inteligentes que criamos, e freqüentemente elas se intrometem de fato naquilo que queremos dizer. Curioso é que apesar do desmanche conceitual da linguagem, epicentro oracular daquilo que entendemos por comunicação, os olhos continuam a pousar como aquilo que invariavelmente não mente: uma troca invisível. Eu realmente olhava para as pessoas na galeria. Para mim, os olhos são uma porta para algo mais, e, o que quer que esteja acontecendo em suas vidas, eu percebo ${ }^{29}$.

O que permite o contrato fundante da sociabilidade, a lealdade aos contratos sociais, é sua constante e irrecusável constatação visual. Pode-se permanentemente por à prova o dito, desmentindo-o por meio do fornecimento abundante de provas visuais. Ver era então um quase sinônimo de constatar, e ocorreu aqui que não mais se vê, e então, não se constata. O Olhar, pilar da filosofia existencialista de Sartre, é abandonado neste medium como elemento secundário e de menor importância. $\mathrm{O}$ resultado do esvaziamento do olhar é a constatação da perversa intencionalidade de quem vê. É incrível quão desarmado nos sentimos sem ver o que queremos. Cego, aliás, é também um sinônimo para tudo que não funciona, que é impotente ${ }^{30}$.

Se houve a vez em que o olhar tudo registrou, houve então a vez em que o olhar tudo imaginou. 
Richard Sennet dizia que quando todos se vêem e se vigiam mutuamente, a sociabilidade diminui: $o$ silêncio é a única forma de proteção. Isso quer dizer que as pessoas são tão mais sociáveis quanto mais existirem barreiras tangíveis entre elas, quanto menos se verem umas às outras. O ambiente público teria como função aproximá-las em segurança ${ }^{31}$. A necessidade de barreiras que distanciem as pessoas afrouxando assim a observação íntima - é o que viabiliza a sociabilidade. Sem se verem, longe dos rostos umas das outras, as pessoas se sentem livres para interagir. Talvez por isso os chats produzam essa estranha prática de grupos, pois a distância e a abolição do olhar, característica reincidente na CMC, emerge como diagrama de uma lógica que favorece o risco, a entrega e o teste com o outro, com o nãoconhecido. Se o olhar é amortizado, isso não resulta em separação mas, paradoxalmente, em sociabilidade.

Eu definiria civilidade da seguinte maneira: É a atividade que protege as pessoas uma das outras e ainda assim permite que elas tirem proveito da companhia uma das outras. Usar máscara é a essência da civilidade. As máscaras permitem a sociabilidade pura, separada das circunstâncias de poder, do mal-estar e do sentimento privado daqueles que as usam. A civilidade tem por objetivo a proteção dos outros contra serem sobrecarregados por alguém. ${ }^{32}$

O rosto, pode-se afirmar, guarda uma função policialesca e autoritária, e seu afrouxamento cria melhores condições para a sociabilidade, como diz Sennet. A cultura ocidental se presentifica na função de rostos, fazendo visível sua força e autoridade: o bebê olha o rosto da mãe, a publicidade traz insistentemente super-rostos, a televisão mesma é um rosto; no jornal abundam caras e bocas. O déspota mostra aos seus súditos seu rosto solar, inalcançável, que por si só resume toda sua pessoa e poder num corpo significante. Todo o regime de significante despótico é referendado por um rosto, que mesmo virtualmente deve reterritorializar no sistema a substância do significante despótico: Rosto é o ícone próprio do regime significante, a reterritorialização interior ao sistema, a substância do significante. $O$ suplicado é antes de tudo aquele que perdeu o rosto. Alguém que entra em um devir-animal, em um devir-molecular, cujas cinzas espalhamos ao vento ${ }^{33}$.

Há então uma dimensão do rosto que é um dispositivo de poder e um recurso do discurso de poder. Em sua ordenação, o rosto impõe um poder modelizado, com restrições ao plano da fantasia e seu motor desejante. Os códigos rostificados ${ }^{34}$ são altamente sobrecodificados, as coisas são claramente dadas e delimitadas. Em uma novela, os closes pululam de ator para ator ou atriz, e a perfeição e solidez do rosto não deixa escapatória: fulano é mau, sicrano é bom, basta ver seu rosto. O estertor do rosto quer eliminar o universo da fantasia, o que significa em última instância abrir mão do real.

No rosto, tal como entende Deleuze, há uma superfície para o disciplinamento dos discursos que opera contra o desejo, um aprisionamento dos sentimentos. O rosto é deliberadamente político, um invólucro 
exterior daquele discurso totalizante, é sua roupagem expressa ${ }^{35}$. Não fosse pelo rosto, a unidade do significante não manteria sua sobredeterminação, como lembram as frases de ordem "olhe para mim quando falo com você" ou "olhe bem para minha cara". Mães, policiais, professores usam uma língua toda estruturada por uma rostificação específica, tecendo um corpo significante que anula expressões rebeldes a as submete às significações estabelecidas.

Então o rosto como face, máscara, imprescindível instrumento da repressão social, com seus políticos de muitos rostos trabalhados pela publicidade de massa. É salutar que uma campanha publicitária se faça por uma miríade de rostos sorrindo, transmitindo carisma e apoio. O rosto vira ícone de confiança, seriedade e competência. O rosto é uma superfície a ser trabalhada em toda sua potência e perversidade.

O rosto está em todo lugar produzindo incessantemente sobrecodificações, há uma máquina abstrata da rostidade, uma produção social do rosto. Há no rosto humano uma peculiar inumanidade, ele é por natureza um close, alternando superfícies brancas (inanimadas) com buracos negros (brilhantes). Seu tédio vazio suga tudo para dentro. O rosto é uma imensa máquina de poder, como provam todas as manequins de revistas e seus rostos imperiais. Deleuze diz que caberia ao homem vencer essa máquina de captura, tirar a couraça do rosto e tornar-se imperceptível, oculto, e se possível, invisível. Eliminar os traços de rostidade da organização do rosto, como faz Henry Miller com seu olhar raio-x: já não fito mais os olhos da mulher que tenho nos braços, mas nado através dela, com cabeça, braços e pernas, e vejo que atrás das órbitas dos olhos há uma região inexplorada, o mundo futuro, e aqui não há lógica alguma $^{36}$.

É por isso que esse medium é um estar, antes de ser um estado visível. Essa conversa sem face, sem olhares, é essencialmente disruptiva porque é formalmente contrária à formação de faces. As próprias imagens da alteridade surgem quebradas, fracionadas e potencializadas pela imaginação trabalhadeira do usuário fantástico e prestidigitador ${ }^{37}$. Seus objetos de interação permanecem em constante desarranjo, agenciados tão somente pela megamáquina técnica da Grande Rede. O necessário processo de construção de uma identidade, de unidades e grupos, é lento demais, não chegam com suficiente rapidez para dar conta da explosão que a rede impõe.

É como se essa linguagem fosse uma experiência para além da rostificação, mas não é exatamente disso que se trata. Quando abolido o plano do rosto, o controle do corpo do significante desaparece e com isso o império da fantasia volta à tona. Decerto os chats possibilitam essa dimensão imaginativa, pois como medium ele desconstrói os signos regidos pela processualidade significante. A ausência de rostos nos chats libera o fluxo do sonho, como vimos anteriormente. Guillaume fazia essa diferenciação sobre a sociabilidade em rede e entendia que elas guardavam uma dimensão libertadora, constituindo em si uma 
solução para os impasses da esterilidade comunicacional moderna ${ }^{38}$. Isso porque no rosto, eu me escondo. Sem o rosto, a sociabilidade pode ser mais verdadeira.

Mas o fato é que mesmo sem rosto, eu continuo me escondendo por meio da linguagem. O equívoco consiste em acreditar que seria possível às pessoas se mostrarem aos outros quando, substancialmente, elas nem sequer conseguem se mostrar a si mesmas. Mas se o ocultamente muda de lugar, espécie de operação metonímica, para onde ele vai? Desloca-se para dentro de si, circulando e visitando ângulos diversos do abismo pessoal, adiando permanentemente a solidão última do $\mathrm{Eu}$ que não guarda a possibilidade de um consolo enunciável. A situação que abre esse capítulo mostra aqui sua pungência, pois enquanto não se conhece a si mesmo, não é também possível vir a conhecer o outro.

Nesse espetáculo de massas que faz desaparecer a face, continuamos terminantemente perdidos na rostidade do nosso abismo pessoal. Isso porque a ausência do rosto não é produto de um contexto alienígena e estranho à produção continuada de imagens da contemporaneidade. Se não há um rosto a ser identificado, isso ocorre não por um virtual enfraquecimento da rostificação, mas por sua onipresença, pela maldição que seus agentes sofrem de não poderem se furtar a essa condição. É mesmo um paradoxo: a condição de agentes comunicativos que não se vêem é tributária dos elementos mais orgânicos da sociedade da imagem, e a existência de um medium em que a palavra não é mediada por imagens só faz sentido em uma sociedade que não consegue se furtar de sua imagem especular. A ausência do rosto não é uma erupção que a tudo liberta, que supera a sociedade da imagem. É antes seu correlato, seu reflexo imediato e é por isso que a linguagem dessa carne tem a cor do plástico. Plástico obturado na carne.

Não é por isso apenas uma escrita de amantes da palavra em suas diversas formas e variações ${ }^{39}$. Estes também são produtores de imagens e consumidores de formas, expressando suas criações em um texto que é insidiosamente uma forma, e incidentalmente um rosto. Mas essa forma ou rosto já não podem ser resumidos pela rostificação de que falávamos anteriormente, nem pelos elementos da ciência política e suas formas de repressão semiológicamente definidas. O retrato dessa forma não chega a um desenho final. Seus operadores se transferem de uma imagem para outra, em movimentos sucessivos que não permitem a definição de apenas um rosto. Se a idéia de um baile de máscaras é interessante para explicar a incrível permuta de nicks (máscaras) no meio, o é não por uma suposta alternância lancinante das identidades, mas porque elas mesmas não se formam na solidez tal como foram entendidas pela individualidade moderna. O baile de máscaras pode ajudar a entender não aquilo que comumente se faz alarido, que é a mutação incessante de identidades, mas sim uma identidade que não se define, que é cortada e recortada por sincopações de elementos distintos e disformes. O rosto é, ele mesmo, um corte, um zapping! 


\section{NOTAS}

${ }^{1}$ Leminski, Paulo. O ex-estranho. São Paulo: Iluminuras, 2001. (p.21).

${ }^{2}$ A frase que abre o livro Neuromancer já se tornou lugar-comum nos estudos comunicacionais. É encontrada sempre que se quer fazer referência ao universo sensorial da grande rede. A frase, no original, é essa: "The sky above the port was the color of television, tuned to a dead channel." Gibson, Willian. Neuromancer. New York: Ace Book, 1995. São Paulo: Aleph, 2003

${ }^{3}$ Kafka, Franz. Sonhos. Quarto caderno in-oitavo, 07/02/1918. São Paulo: Iluminuras, 2003. (p.111).

${ }^{4}$ Flusser, Vilém. Filosofia da caixa preta. São Paulo, Hucitec, 1985. (p.82).

${ }^{5}$ Seguindo o princípio de que o homem é a medida de todas as coisas, Górgias entendia que o ser não existe, e se existisse, não poderia ser conhecido, e se o fosse, não poderia ser comunicável ou enunciável: "Heráclito, Parmênides, Górgias e Platão duvidam da comunicação. Mas por motivos diferentes, até mesmo opostos. Parmênides e Platão duvidam partindo da imutabilidade do ser e do fato de as aparências encobrirem um ser 'verdadeiro' que estaria escondido. As palavras só pegam esse ser aparente: referem-se às qualidades e não à 'essência' imutável do ser. Heráclito duvida, partindo da mutabilidade do ser. Para ele, os homens também enganam-se pelas aparências, mas não há uma 'essência imutável' atrás dos véus. Há uma impenetrabilidade na alma que seria profunda e ilimitada. É também a direção de Górgias, que é descrente de qualquer capacidade humana de atingir o universo além das palavras. Só que para ele, o segredo não está nem no mundo das Idéias de Platão nem na alma insondável de Heráclito, mas na própria interioridade, na incomunicabilidade humana profunda." Marcondes Filho, Ciro. Até que ponto, de fato, nos comunicamos? São Paulo: Paulus, 2004. (p.49).

${ }^{6}$ Heidegger trabalha o conceito de "desabrigar" através de uma série de alternâncias, sobretudo com os termos her-vorbringen, entbergen e dar-stellen. O primeiro vocábulo, segundo o tradutor do ensaio, procura marcar o movimento (bringen) que descobre, pondo-se à frente (vor) em relação a uma situação encoberta. "Entbergen significa, na terminologia de Heidegger, um 'des-abrigar' (ent-bergen)" (p.53, nota de rodapé). O próprio autor explica a finalidade do vocábulo darstellen: “A palavra 'pôr' (stellen) designa no título armação (Ge-stell) não somente o desafiar. Mas ela deve imediatamente

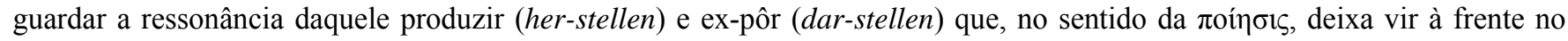
descobrimento o que está presente." (p.67, $2^{\circ}$ parágrafo). O conceito de desabrigar funciona como uma chamada para a essência do que se descobre, experimentando assim o pertencimento, movimento duplo que compreende o fato de o homem não ser senhor de seu destino e da história (alguém, então, habitualmente aproveitado) mas, ao mesmo tempo, é ele mesmo o primeiro a se oferecer a algo maior, que lhe ultrapassa. "O homem está, a partir do destino, colocado em perigo. O destino do desabrigamento é em todos os seus modos, um perigo, e por isso, necessariamente um perigo." (p.77). Nota do tradutor sobre este trecho: "Entenda-se 'necessariamente' no sentido de 'destino'. Faz parte da essência do ser humano estar disposto e exposto a um modo de desabrigar e é preciso resguardar justamente isso, o desabrigar que, em certa medida, é o próprio estar desabrigado do homem". Heidegger, Martin. Dir Frage nach der Technik. A questão da técnica. Tradução de Marco Aurélio Werle. Cadernos de tradução. Departamento de Filosofia da USP, N.2, 1997.

${ }^{7}$ Merleau-Ponty, Maurice. A prosa do mundo. Rio de Janeiro: Bloch, 1974. (p.44).

${ }^{8}$ Deleuze, Gilles. Diálogos. São Paulo: Escuta, 1998. (p.12). A idéia de uso menor da língua, componente usual do conceito de devir em Deleuze, pode em alguma medida ser encontrada em Merleau-Ponty, como se vê aqui: "A filosofia só pode, no que toca à linguagem, mostrar com o dedo como, pela deformação coerente dos gestos e dos sons, o homem chega a falar uma língua anônima, e pela deformação coerente dessa língua exprimir o que só existia para ele.” Merleau-Ponty, Maurice. A prosa do mundo. Rio de Janeiro: Bloch, 1974. (p.123). Em Deleuze e Guattari, assim fora expresso: “Eu misturo sons inarticulados, alongo os termos de transição, utilizo igualmente aposições justo onde não seriam necessárias.' Ganhar tempo, e depois talvez renunciar, ou esperar. Necessidade de não ter o controle da língua, de ser um estrangeiro em sua própria língua, a fím de puxar para si e 'pôr no mundo algo de incompreensível'”. Deleuze, Gilles. \& Guattari, Félix. Mil Platôs Capitalismo e Esquizofrenia. São Paulo: Editora 34, 2000. Vol.5. (p.48).

${ }^{9}$ Sobre os tais hackers que atuam dentro da legalidade da arte: "Angela Detanico e Rafael Lain questionam os signos como sistema apto a representar a realidade. Uma prática que remonta à filosofia platonicista. E, no entanto, é como se cada novo trabalho dessa dupla de artistas viesse dizer que há muito ainda a ser dito sobre linguagem, ciência e cidade. Se, por um lado, o problema da representação permaneceu ao longo da história, por outro, é preciso reconhecer que o tempo modificou sua modulação.” Jornal Folha de São Paulo. Hackers debatem a representação da realidade. Ilustrada, 22/04/2004. Disponível em: http://www1.folha.uol.com.br/fsp/ilustrad/fq2204200408.htm

${ }^{10}$ Merleau-Ponty, Maurice. A prosa do mundo. Rio de Janeiro: Bloch, 1974. (p.49).

11 "Se queremos compreender a linguagem em sua operação significante de origem, precisamos fingir nunca ter falado, operar sobre ela uma redução sem a qual ela se esconderia a nossos olhos reconduzindo-nos ao que significa para nós olhá-la como surdos olham os que lhes falam, e comparar a arte da linguagem às outras artes da expressão que não recorrem a ela, tentar vêla como uma dessas artes mudas". Merleau-Ponty, Maurice. A prosa do mundo. Rio de Janeiro: Bloch, 1974. (p.60).

12 Embora a idéia de co-pertencimento seja em muito próxima à intencionalidade fenomenológica, é preciso pensá-la desvinculada de uma valoração unitária, de uma idéia de sujeito que a fenomenologia não consegue abrir mão. Seria antes uma conjunção ou co-pertencimento que altera o estatuto da relação sujeito-objeto e que pode ser mais bem entendida pela idéia de compossibilidade que Deleuze trabalha, retomando um tema de Leibniz. Trata-se, fundamentalmente, de trabalhar conseqüências não-causais, compatibilidades ou incompatibilidades alógicas; dimensão em que a contradição está inserida na composição, sem a impossibilitar: "o primeiro teórico das incompatibilidades alógicas, e por isso o primeiro grande teórico do acontecimento, foi Leibniz. Pois o que ele chama de compossível e incompossível não se deixa reduzir ao idêntico e ao 
contraditório, que seguem somente o possível e o impossível. A compassibilidade não supõe nem mesmo a inerência dos predicados em um sujeito individual ou mônada”. Deleuze, Gilles. Lógica do Sentido. São Paulo: Perspectiva, 2003. (p.177).

13 "O que nos resta fazer é, de certa forma, assestar um projetor, manter a abertura telescópica sobre esse mundo virtual, esperando que alguns desses acontecimentos façam a gentileza de se deixar apanhar. A teoria só pode ser isso: uma armadilha preparada na esperança de que a realidade seja suficientemente ingênua para se deixar apanhar. O essencial é assestar o projetor na boa direção. Mas não sabemos onde fica a boa direção. É preciso escrutar o céu. Na maioria das vezes, trata-se de acontecimentos tão longínquos, metafisicamente longínquos, que só despertam uma leve fosforescência nas telas. É preciso revelá-los e ampliá-los, pois não são logogramas e sim hologramas. Não têm mais explicação do que o espectro fixo de uma estrela ou as variações do vermelho." Baudrillard, Jean. A Transparência do Mal: ensaio sobre os fenômenos extremos. Campinas: Papirus, 2003, (p.117).

${ }^{14}$ Além das proposições respeitantes ao método por nós utilizado, o objeto em questão coloca uma série de desafios. Se o estudo das comunidades virtuais já é em si mesmo complicado, o que dizer de um estudo focado em conversas entre duas pessoas, apenas acessível a elas? Por isso, fazer suar o objeto na análise, não separando o que é observação do que é observado. É mais do que observação participante, sendo participação que, também, observa a observação, nos termos de Niklas Luhmann: observação de segunda ordem. "Lea e Spears admitem que uma análise abrangente da CMC não é por enquanto possível. Nem nunca será, na minha opinião. Limitada atualmente aos 'poucos dados disponíveis', a própria natureza da $\mathrm{CMC}$ sempre colocará problemas aos pesquisadores. A maioria das pessoas, se perguntadas, nunca permitirá que sua correspondência seja acessada de qualquer forma. É mais fácil estudar a interação de grupos, mas como fazer para estudar a CMC no nível um-a-um? " No original: "Lea and Spears admit that the comprehensive analysis of CMC is not currently possible. In my opinion, it never will be. Currently limited by the 'paucity of available data', the very nature of CMC will always pose problems for researchers. Most people are not going to knowingly allow access to their personal correspondences, in any format. It is easier to study group interaction, but how does one study CMC at the one-on-one level?" Chenault, Brittney G. Developing Personal and Emotional Relationships Via Computer-Mediated Communication. CMC Magazine. Disponível em: http://www.december.com/cmc/mag/1998/may/chenault.html. A dificuldade para se infiltrar no objeto não pode, no entanto, ser tomada como objeto em si mesmo, ou seja, não basta constatar a fragilidade da operação, é preciso arriscar sob a pena de produzir mais um roteiro de obviedades mortais. Isso porque não é possível dissociar a maneira como uma pesquisa é feita de seu conteúdo final; melhor dizendo, são as operações utilizadas e operadas sobre as questões propostas que vão condicionar o produto final, tal como expressou Hegel: “A forma sistemática da pesquisa não é separável de seu conteúdo, isto é, do próprio 'movimento do conceito"'. Clement et alii. La philosophie de A à Z. Paris, Hatier, 1994, (p.229). APUD Marcondes Filho, Ciro. Por uma Teoria da Comunicação para a Era Tecnológica. Projeto Temático FAPESP, Coordenador: Ciro Marcondes Filho. ECA/USP, Departamento de Jornalismo e Editoração, Núcleo Jornalismo e Cidadania.

15 “As substâncias expressivas lingüísticas e não-lingüísticas se instauram no cruzamento de cadeias discursivas pertencentes a um mundo finito pré-formado (o mundo do grande Outro lacaniano) e de registros incorporais com virtualidades criacionistas infinitas. É nessa zona de interseção que o sujeito e o objeto se fundem e encontram seu fundamento. Trata-se de um dado com o qual os fenomenólogos estiveram às voltas, ao mostrar que a intencionalidade é inseparável de seu objeto e depende então é da ordem de um aquém da relação discursiva sujeito-objeto". Guattari, Félix. Caosmose: um novo paradigma estético. São Paulo: 34, 1992. (p.37).

${ }^{16}$ Nos termos trabalhados no Projeto Temático "Por uma Nova Teoria da Comunicação", coordenado pelo Professor Ciro Marcondes Filho, do qual este trabalho é parte e que versa, entre outros princípios metodológicos, sobre o Princípio da Razão Durante. Excertos podem ser encontrados em: http://www.eca.usp.br/nucleos/filocom//razao.html

17 "Sujeitar-se continuamente a uma condição na qual a experiência física e a emoção são constantemente expressadas em palavras é problemático. Nossa cultura com freqüência considerou que o enorme prisma de emoções e experiências que simplesmente não são passíveis de expressão lingüística não merecem atenção, o que prejudica a saúde emocional. Corpos vivos e reais encontram-se desvalorizados em uma era onde a recepção passiva da informação selecionada veio para repor como realidade a experiência vivida." McRae, Shannon. Carne feita palavra: sexo, texto e o corpo virtual. Disponível em: http://members.fortunecity.com/cibercultura/vol5/carpal.html

${ }^{18}$ Kamper, Dietmar. As máquinas são tão mortais quanto as pessoas. Uma tentativa de excluir o telemático do pensamento. Tradução de Ciro Marcondes Filho. Disponível em: www.eca.usp.br/nucleos/filocom/traducoes.html

19 "Eu e Menezes, voláteis, cafajestes desprovidos de caráter; somos uns ordinários. Qualidades fundamentais aos navegantes. De galho em galho, qual Tarzan in virtuais Forests, não sou de ninguém. E pago o preço, me flagro dispersa. Estranho tipo de atenção. Capaz de capturar-me por horas, de olho numa tela inóspita e alienante, mas vigorosa, que me impulsiona a partir, em bom linguajar hippie, mó viagem". Pellegrino, Antonia. Blog Inveja de Gato - um gato brasileiro e vira-lata e meu. 11/11/2003. Disponível em: http://www.invejadegato.blogger.com.br/

${ }^{20}$ Como nos sonhos - ou pesadelos - que Kafka relata: "O aparelho era construído de tal modo que bastava apertar um botão e imediatamente a resposta vinha de Berlim e aparecia nas fitas de papel. Lembro-me de como, paralisado de expectativa, vi a primeira fita saindo vazia. E que alegria quando os primeiros caracteres apareceram na fita; de tanta alegria, eu deveria ter caído da cama, se bem me lembro. Carta a Felice Bauer, 07/08/1912.” Kafka, Franz. Sonhos. São Paulo: Iluminuras, 2003. (p.57-58).

21 "O carteiro chegava com duas cartas suas, registradas, e me entregava uma em cada mão, movendo os braços com uma precisão magnífica, com êmbolos de uma máquina a vapor. Deus, eram cartas mágicas. Por mais páginas que eu tirasse dos envelopes, eles nunca se esvaziavam. Eu estava no meio de uma escada e, não me leve a mal, precisei espalhar as páginas lidas pelos degraus para poder continuar tirando as outras dos envelopes. A escada estava coberta de alto a baixo por uma espessa camada de cartas lidas, o papel elástico rumorejava com impotência. Carta a Felice Bauer, 17/11/1912.” Idem, (p.56). 
${ }^{22}$ Cujo interessante paralelo é proporcionado pelos escritos da "rainha do cyberpunk", Pat Cadigan, onde o ciberespaço é apresentado como um conjunto de linhas orgânicas, nas quais o silício e o metal não se desvinculam da corporeidade, dos detritos e das "entradas" e "saídas" próprias aos mamíferos: "É tudo o que lá estava: apenas linhas", disse Travis. "Conectemo-las diretamente entre si. Redes, sangue, mijo, e merda. Do jeito que a camareira do hotel os encontrou". APUD Plant, Sadie. Gozando Futuro Afora. Disponível em: http://members.fortunecity.com/cibercultura/vol5/gozfut.html

23 "Quanto mais intensamente os indivíduos experientes em sexo virtual sentem prazer, mais hábeis eles se tornam para evocar intensidades físicas em palavras, saltando sobre o buraco entre o discurso e a ação, liberando a corrida das sensações físicas e o êxtase do autor em produzir texto, estar no texto e estar no corpo de forma simultânea." McRae, Shannon. Carne feita palavra: sexo, texto e o corpo virtual. Disponível em: http://members.fortunecity.com/cibercultura/vol5/carpal.html

24 "Interativo é o sistema que se abre e nos recebe, como uma construção arquitetônica nos recebe. (...) Quando imersos num mundo, sempre caminharemos num percurso que ninguém caminha e realizamos uma interatividade que acontece muito próxima da definição de conversa (Unterhaltung), pois nada é mais representativo do mundo interativo do que o diálogo. Na música, no cinema ou no vídeo é a relação com o diálogo que sempre nos impressiona.” Bairon, Sérgio \& Petry, Luís Carlos. Psicanálise e História da Cultura. São Paulo: Educs/ Mackenzie, 2000. (p.51 e 52).

${ }^{25}$ E continua: "Deposito minha confiança em palavras. Os gurus da mídia podem falar de como não precisaremos de histórias já que teremos mundos novos e virtuais, mas logo esses novos mundos, também, terão suas próprias histórias e nós desejaremos novos mundos para inseri-las. Estou dizendo que a linguagem nos dá o exemplo mais claro e a forma mais óbvia para aquilo que emergirá como uma forma verdadeira de arte narrativa eletrônica." Joyce, Michael. Formas de futuro. IN: Leão, Lúcia (org). Interlab - Labirintos do pensamento contemporâneo. São Paulo: Iluminuras, 2002. (p.50).

${ }^{26}$ Bairon, Sérgio \& Petry, Luís Carlos. Psicanálise e História da Cultura. São Paulo: Educs/ Mackenzie, 2000. (p.112).

27 "Deleuze duplica o mundo criando outro equivalente mas diferente; não se trata de avaliar, criticar, interferir no mundo, mas de realizá-lo diferentemente, como virtualidade. O virtual não tem nada que ver com o possível, como quem diz, há estes objetos, mas há virtualmente outros. Não, o virtual está no plano do Ser do(s) ente(s). O que temos diante de nós, as coisas como elas se mostram, é uma forma de atualização, de realização do virtual, é o Uno se mostrando, é a face do Uno no real, [como no caso das] variações da palavra dog. 'Considere-se, por exemplo, várias pronúncias de uma palavra dada. A pronúncia 'padrão' de uma palavra não é uma constante diante da quão são medidas variações regionais, de classe ou ocupacionais, mas, ela mesma, uma variável numa relação particular com outras variáveis. 'Dog', 'dawg' e 'dag', por exemplo, podem servir como aproximações grosseiras das três pronúncias possíveis da palavra dog, três variáveis, uma das quais talvez estatisticamente mais comum e mais prestigiada que as outras, mas nenhuma delas é estável ou fixa. As três variáveis são internas à língua, cuja estrutura deveria ser descrita em termos de 'linhas de variação' abstrata mais do que constantes. Neste caso particular, a 'linha de variação' passa por 'dog', 'dawg', 'dag' e qualquer outra pronúncia da palavra em inglês. Esta linha de variação é virtual, isto é, real sem ser atual'. (Deleuze, $M P$, p.119)”. APUD Marcondes Filho, Ciro. $O$ escavador de silêncios - formas de construir e desconstruir sentidos na Comunicação. São Paulo: Paulus, 2004. (p.189).

${ }^{28}$ A frase é de Flávio Aguiar, definindo a condição da linguagem na contemporaneidade, ao prefaciar (na orelha do livro) 'Geração 90 - os transgressores'. Ver: Oliveira, Nelson. Geração 90 - os transgressores. São Paulo: Boitempo, 2003.

${ }^{29}$ O comentário completo de Marina Bramovic sobre sua instalação é este: "Eu estava lá para ser projetada, a coisa toda precisa ser quase uma troca invisível. Você perguntou como era a conexão naquela performance. Eu realmente olhava para as pessoas na galeria. Para mim, os olhos são uma porta para algo mais, e, o que quer que esteja acontecendo em suas vidas, eu percebo. Você não pode imaginar o quanto chorei naquela performance. Essa tristeza vem porque eles projetam a sua própria tristeza em mim e eu a reflito de volta. As pessoas vinham como bêbados, em vez de uma dose de vodka eles vinham procurar uma dose dessa conexão com os olhos. Eles vinham de manhã; às $8 \mathrm{~h} 45$ estavam lá esperando, com roupa de trabalho. A galeria abria às $9 \mathrm{~h}$, e eles entrava, olhavam para mim durante uns 20 minutos e iam embora. Muitos depois me disseram que nem sequer estavam ligados à arte. Eu estava pensando que geralmente as pessoas não olham para eles dessa forma íntima, então talvez só precisassem ser vistos daquela forma antes de ir trabalhar". Aventuras pelo Invisível. Jornal Folha de São Paulo, Caderno Mais!, Domingo, 17/08/2003. (p. 4-9).

${ }^{30}$ A língua portuguesa guarda uma série de significações laterais ao verbo olhar, que não são de maneira alguma difíceis de se deduzir de seu sentido lato. Olhar, segundo o Dicionário Houaiss de Língua Portuguesa, também é prestar atenção a; ponderar, tomar conta de; encarregar-se, ter por; reputar, julgar, considerar, dar proteção a, ocupar-se intensamente de; interessar-se, interpretar. O termo tem raiz indo-européia (weid), e compreende-se que olhamos para 'tomar conhecimento' de algo tanto quanto para 'ter um conhecimento' de algo. No Latim vulgar, adoculare, de onde provavelmente o vocábulo provém, significa dar direção para algum lugar ou objeto, também possível nas variações dar vista; esclarecer. Ou seja, a relação que o olhar estabelece na prática de ver e tomar para si é literal e nada difusa. havendo uma relação inextricável entre ver e conhecer. É então salutar o paralelo entre a forma preponderante das pessoas se comunicarem até então, no face a face ou olho no olho, e essa variante tecnológica que elimina a proeminência do olhar. Aqui, a palavra antecede o olhar. As pessoas, que agora se encontram fora do "poder" do olhar, vão delineando outros instrumentos de conhecimento, outros olhares. Como vimos nos capítulos precedentes, tais componentes são essencialmente imaginativos e fantasiosos. Sobre as acepções etimológicas: Houaiss, Antônio. Dicionário Houaiss da Língua Portuguesa. São Paulo: Objetiva, 2001.

31 "Os seres humanos precisam manter uma certa distância da observação íntima por parte do outro para poderem se sentir sociáveis. Aumentem o contato íntimo e diminuirão a sociabilidade. Esta é a lógica de um tipo de eficiência burocrática". Sennet, Richard. O Declínio do Homem Público. São Paulo, Cia das Letras, 1989. (p.29).

${ }^{32}$ Idem, (p.323).

${ }^{33}$ Deleuze, Gilles. \& Guattari, Félix. Mil Platôs - Capitalismo e Esquizofrenia. (p.145). APUD Marcondes Filho, Ciro. O escavador de silêncios - formas de construir e desconstruir sentidos na Comunicação. São Paulo: Paulus, 2004. (p.145). Ver 
a esse respeito: Deleuze, Gilles. \& Guattari, Félix. Mil Platôs - Capitalismo e Esquizofrenia. Vol. 3, $2^{\circ}$ cap. ( $7^{\circ}$ platô): Ano Zero-Rostilidade. São Paulo: Editora 34, 2000. (p.31-61).

34 "Nenhum antropomorfismo. A rostificação não opera por semelhança, mas por ordem de razões. É uma operação muito mais inconsciente e maquínica que faz passar todo o corpo pela superfície esburacada, e onde o rosto não tem o papel de modelo ou de imagem, mas o de sobrecodificação para todas as partes descodificadas. Tudo permanece sexual, nenhuma sublimação, mas novas coordenadas." Segue assim na página seguinte: "O rosto não é animal, mas tampouco é humano em geral, há mesmo algo de absolutamente inumano no rosto. É um erro agir como se o rosto só se tornasse humano a partir de um determinado limiar: close, aumento exagerado, expressão insólita, etc. O rosto é inumano no homem, desde o início; ele é por natureza close, com suas superfícies brancas inanimadas, seus buracos negros brilhantes, seu vazio e seu tédio. Rostobunker. A tal ponto que, se o homem tem um destino, esse será mais o de escapar ao rosto, desfazer o rosto e as rostificações, tornar-se imperceptível, tornar-se clandestino. (...) O rosto tem um grande porvir, com a condição de ser destruído, desfeito. A caminho do assignificante, do assubjetivo. Mas ainda não explicamos nada do que sentimos." Deleuze, Gilles. \& Guattari, Félix. Mil Platôs - Capitalismo e Esquizofrenia. São Paulo: Editora 34, 2000. Vol.3. (p.35;36).

35 "O outro é rosto. O rosto não é metáfora, mas epifania. O rosto não significa nada, simplesmente se expressa". Mèlich, Joan-Carles. A resposta do outro: a carícia. IN: Larrosa, Jorge \& Pérez de Lara, Nuria (orgs.) Imagens do Outro. Petrópolis: Vozes, 1998. (p.173).

${ }^{36}$ Miller, Henry. Trópico de Capricórnio. São Paulo, Círculo do Livro, 1975. (p.112).

37 "Qualquer tecnologia suficientemente avançada é indistinguível de mágica". Clarke, Arthur C. 3001 - The Final Odyssey. New York: Ballantine Books, 1998.

${ }^{38}$ Guillaume fazia uma diferenciação entre comunicação face a face e comunicação mediada por computador, alertando para as diferenças entre elas. Contestando que a comunicação face a face produza uma sociabilidade pura, o autor não crê que a sociabilidade esteja se perdendo, pois para Guillaume a sociabilidade face a face se resume a uma seqüência de etapas convencionais onde uma conversa se resume a funções fáticas - que servem tão somente para afirmar a presença dos interlocutores, tal com entende Umberto Eco - como quando se diz "como vai você, tudo bem?" ou ainda "hoje está muito calor, não?", frases já desprovidas de efetiva troca real, de qualquer comunicação. Há nestas conversas uma alternação de perguntas e respostas automatizadas, sem qualquer significação particular. Diferentemente da comunicação face a face, a comunicação em rede talvez pudesse ser mais verdadeira, na medida em que se encontra livre das inibições do rosto e da presença corpórea. As redes eletrônicas seriam, para o autor, uma solução para o estado letárgico que a sociabilidade face a face chegou. Ademais, não haveria uma perda ou substituição da sociabilidade "real" frente às agregações em rede, mas relações diferenciadas em que uma se somaria a outra, sem sobreposição. Para tanto, ver: Guillaume, Marc. Téléspectres. IN: Traverses, $\mathrm{n}^{\circ} 26$, out/1982, (p.18-28).

${ }^{39}$ Sobre as formas que a escrita dos chats tomam, sem ser um rosto apenas, podemos arriscar uma interpretação temerosa e extemporânea, razão pela qual ela é apresentada em nota de rodapé e não no corpo do texto. Há na escrita uma indissociável função repressiva, dado que o signo escrito - como lembra Derrida - sempre foi a forma primeira de manifestação de poder. Há na escritura uma extensão da violência, que não vem de fora mas de dentro da própria linguagem. É um efeito construído historicamente pela dissimulação da arquiescritura, pelo desejo interno que jaz na palavra de exterminar o seu duplo, sua outra face. E os signos sabem disso, pois guardam na memória outros cenários e contextos em que seu forjar teve uma outra relação com os demais signos e com a significação mesma. A palavra, inspirada por uma voz distante, repete essa matriz e dissimula a arquiescritura que assim não pode vir à tona. Não por menos Artaud dizia que as palavras são roubadas, que não pertencem a mim e que são apenas repetidas. Nos termos do autor do Teatro do Absurdo, a revolução deveria começar pela destruição da palavra. A carne cor de plástico dos chats, de que esse capítulo faz referência, consistiria num virtual truque de tentar trazer a arquiescritura de que fala Derrida para a superfície, traindo a escritura com seus próprios elementos: usar a escrita não para escrever, mas para falar e falar apenas. Seriam expressões que, em um sentido heideggeriano, "des-cobrem", que fraturam o encobrimento da arquiescrita, desvelando-a. Sua artificialidade ou plasticidade se forjaria na simulação da fala oral, pela escritura, inversão que desnudaria a violência primal do grafo. Quando eu escrevo a minha fala, faço a atualização da arquiescritura de Derrida e traio a escritura, pois usando-a, recuso seus artifícios de deslocamento e encobrimento da significação que é variável, e em nada estática. Uso a escrita para quebrar sua cristalização, uma tentativa (ainda que vã) de alcançar o traço, aquele rastro que é inacessível à verbalidade. A arquiescritura é "a escritura primeira, não no sentido de precedência histórica à palavra proferida, mas que antecede a linguagem falada e a escrita vulgar" Santiago, Silviano. Glossário de Derrida. Rio de Janeiro: Francisco Alves, 1976. (p.11). Ver a esse respeito: Derrida, Jacques. A escritura e a diferença. São Paulo: Perspectiva, 1971, e também Marcondes Filho, Ciro. O escavador de silêncios - formas de construir e desconstruir sentidos na Comunicação. São Paulo: Paulus, 2004. (especialmente a página 236). 


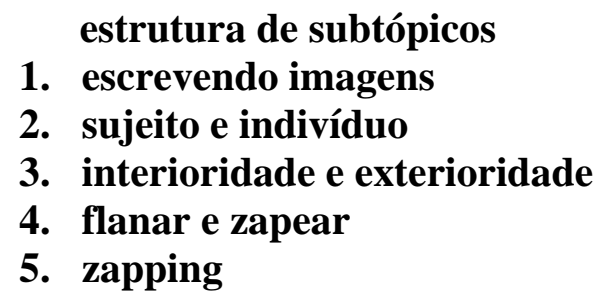

Tudo é temporário. É por isso que sugeri a metáfora da 'liquidez' para caracterizar o estado da sociedade moderna, que, como os líquidos, se caracteriza por uma incapacidade de manter a forma. Nossas instituições, quadros de referência, estilos de vida, crenças e convicções mudam antes que tenham tempo de se solidificar em costumes, hábitos e verdades 'auto-evidentes'. É verdade que a vida moderna foi desde o início 'desenraizadora' e 'derretia os sólidos e profanava os sagrados', como os jovens Marx e Engels notaram. Mas, enquanto no passado isso se fazia para ser novamente 'reenraizado', agora as coisas todas - empregos, relacionamentos, etc. tendem a permanecer em fluxo, voláteis, desreguladas, flexíveis.

Zygmunt Bauman $^{1}$

Vou acrescentar uma nova partícula à micro-física dos simulacros. Depois do estádio natural, do estádio mercantil, do estádio estrutural, eis que chega o estádio fractal do valor. No estádio fractal, já não há nenhuma referência: o valor irradia em todas as direções, em todos os interstícios, sem referência ao que quer que seja, por pura contigüidade. No estádio fractal, já não há equivalência, nem natural nem geral, nem há lei do valor propriamente dita: só há uma espécie de epidemia do valor, de metástase geral do valor, de proliferação e de dispersão aleatória. (...)

É o esquema peculiar ao fractal; é o esquema atual de nossa cultura. Jean Baudrillard ${ }^{2}$ 


\section{ESCREVENDO IMAGENS}

A definição categórica que Baudrillard dá à tela, como espaço de imersão, é central para a compreensão do indivíduo trabalhado nessa pesquisa. Essa tela imersiva não é papiro e assim não pode ser grafada. É uma tela onde indivíduos zapeiam quadros e imagens, mais um processo de montagem e decupagem que de inscrição ou testemunho. A imersão opera por fusões e conjunções, e não por inscrição ou demarcação. Na verdade, embora nos chats se escreva todo o tempo, a lógica que impera é a da imagem ${ }^{3}$.

Isso significa que o destino testemunhal da escrita é reinventado por componentes de conjunção. Ao testamento, à herança indelével que a escrita grafa, a imagem oferece apenas expansão e não mais que expansão. Ao traço certeiro, bricolagens caóticas. À necessária linearidade lógica da escrita, um fluir de quadros esquizóides, onde os frames ultrapassam a lógica cristalina da linha grafada. A extensão sociológica desse debate pode ser observada nos paradigmas de sujeito da modernidade, como é o caso do flanador, em contraposição a esse homem amigo da imagem que chamaremos de zapeador.

Em A farmácia de Platão, Jacques Derrida desconstrói um diálogo de Platão onde Sócrates e Fedro conversavam sobre os méritos da retórica e da filosofia. Sócrates parece convencer seu interlocutor de que a fala é superior à escrita. Seguindo o mito de Theuth, a invenção da escrita é um golpe frente ao poder único da fala, atentando assim contra o poder gerador de vida que ligava a voz do faraó à criação mesma das coisas. A escrita também desagradava na medida em que as pessoas não precisariam mais se lembrar do que sabem. Escreveriam para se esquecer o que sabem.

Esse caráter atemporal que investe o testemunho escrito de certa autoridade, a imagem não tem e não pode vir a ter. Não há um roteiro definido para a decodificação, e a leitura das imagens requer mais imersão que atenção. Paralelamente, a composição imagética conjuga os elementos da visualidade sem necessariamente recorrer a subtrações ou induções. Uma imagem não impõe obstáculos à união com outras imagens, seu código é prontamente afeito a montagens e edições. Imagens querem ser misturadas, não querem guardar a palavra final sobre qualquer coisa. Antes, parecem tender ao desaparecimento.

De fato, são lógicas demasiadamente distintas. Se retomássemos a discussão filosófica do atual e do virtual $^{4}$, poderíamos dizer que a escrita sempre produz, em algum nível, certa atualização, já que se remete decididamente a objetos dispostos no mundo, ao mundo reificado. É como se concretude do real, o mundo atualizado, tivesse no grafo um agente fiel e competente. A imagem, no entanto, é um servo das dimensões do virtual, que não precisa forçosamente se atualizar. A imagem fala ao imaginário, como se sabe, e anseia à imaginação. 
Essas diferentes lógicas de composição, de funcionamento do código escrito e gráfico, ficam mais claras quando pensamos nas estruturas de ordenação. Entre um quadro e outro não há vinculação obrigatória, de onde a evidente quebra com a linearidade. $\mathrm{Na}$ escrita, entretanto, o grafo exige relação contígua de sentido entre as partes precedente e vindoura. Nos chats, de maneira curiosa e incoerente, a evolução não é seqüencial, não é contígua e o sentido "perambula" entre as linhas como na lógica imagética. Trata-se decerto de um medium produzido e entendido pela escrita. Sua lógica, no entanto, é imagética.

A contradição entre diferentes modos de vida dentro de determinada sociedade espelha a interação das diversas ordens sociais, suas particularidades e sentidos ${ }^{5}$. O meio-fio da escrita produzida numa tela, a ser lida em outra tela, é um desses casos. Mergulhar nessa individualidade zapeadora, nesse modelo de subjetividade contemporânea, é de alguma maneira mergulhar em nossa sociedade tecnológica, em sua abertura a oceanos de sentido.

A discussão entre sujeito e indivíduo, que esse trabalho a princípio tenta se furtar, é fundamental. Os capítulos foram encadeados e escritos de uma maneira que não houvesse um sujeito definido, presente, a engendrar processo algum. Houvesse uma centralidade no processo de geração de textos dos chats - e nem acreditamos que possa haver -, ela não seria encontrada em uma figura semântica unitária. O sujeito sociológico é inoperante nesse contexto e por essa razão optamos por outra abordagem. Explicar qual chaveamento conceitual pôde ser utilizado no lugar do centenário sujeito, no entanto, é necessário.

Fossemos retomar a discussão da imagem e da escrita, poderíamos dizer que tal sujeito, então, não se forma na sedimentação segura e concreta do grafo, da linha ou da letra. Forma-se, pelo contrário, pela conjunção de blocos de sentido independentes (ou seja, imagens) sem obedecer a uma ordenação precisa. O sentido, para o tagarela digital, não é trilhado ou seguido pelo thread ${ }^{6}$, mas conjugado independentemente por altercações quase aleatórias. Por isso não se registra, mas se zapeia.

O grafo convoca um sujeito que o produza e um interlocutor, um destinatário que pode ser ele mesmo ou todo o complexo social. A imagem, por outro lado, não clama por um sujeito porque não se direciona a um receptor, definido ou elusivo, desprendida de certo modo do tecido social. Não há o pré-requisito da existência de um receptor que lhe decodifique. Imagens abundam, pulverizando os vínculos discursivos e a tradição de encadeamentos seqüenciais. Como nos termos de Kafka: nada, imagem apenas, nada mais, esquecimento total ${ }^{7}$.

Essa escritura prenhe de lógica imagética assassinara o sujeito. Então há indivíduos, mas não necessariamente sujeitos, uma extensão pessoal oposta à catequese do sujeito sociológico ou psicanalítico. De todo modo, abundam exemplos na própria sociologia e na psicanálise de construções 
teóricas que não dependiam, ou relegavam a um plano secundário, o conceito iluminista de sujeito com sua sujeição e subjetivações. Essa dimensão nos interessa, pois buscamos não uma pessoalidade individualizada, mas a particularidade característica de um personagem ${ }^{8}$.

\section{SUJEITO E INDIVÍDUO}

A assunção teórica que diz haver um sujeito social não pode ser suficientemente apartada do Humanismo, dado que efetiva o imperativo questionador dos valores que suportam a própria concepção de homem. Essencialmente idealista, possibilitou que se formulasse um longo debate sobre a metáfora da interioridade, raiz da psicanálise e do amplo espectro de teorias sobre o homem no decorrer do século XIX e XX. O homem não seria como os outros animais, pois sua interioridade lhe conferiria uma complexidade diferencial impossível de ser apreendida objetivamente, e cujas características iluminariam a compreensão da sociedade.

Essa unidade epistemológica de homem, entendida dentro do binômio Iluminismo e Humanismo, foi deliberadamente esquecida na trajetória deste texto, deslocando-a para acepções descentradas e fluidas, tais como o objeto em questão - os chats - exigia que se fizesse. De fato, abundam reações ao legado iluminista nas mais variadas correntes, mas foi talvez a cibernética de Norbert Wiener ${ }^{9}$ e seus herdeiros que mais radicalmente equacionou essa rachadura, na medida em que o entendimento do homem como centralidade subsumida da sociedade é inteiramente descartado. Atravessando a Escolas de Palo Alto (Bateson), a Escola Chilena de Biologia (Maturana e Varela), tais assunções alimentaram a cibernética de Heinz Von Foerster e contribuíram decisivamente para a Teoria dos Sistemas Sociais de Niklas Luhmann.

Wiener falava não em homem, mas em seres sociais, cujo paralelo com a função dos avatares (nicknames) dos chats é pródiga. Nesse entendimento, a comunicação já não é exclusividade do ser humano, podendo ser processada por avatares que emitem frases e geram encadeamentos discursivos que não se resumem a explanações pessoais, a opiniões. Os discursos, em sentido estrito, não são enunciados por pessoas e nem operacionalmente suportam a categoria de sujeito.

Essa concepção cibernética entende que um ser que se comunique com certa complexidade pode ser entendido como ser social. Não é então o corpo biológico que funda a existência social, mas o espectro informacional dos agentes, entendidos como uma máquina capacitada para se comunicar socialmente: toda a interioridade do homem passa a ser uma exterioridade plena. Mesmo que Wiener fale em homem, ele o caracteriza como potencialidade mediadora, não como indivíduo, rejeitando também o conceito 
sociológico de sujeito estático. Emerge uma concepção de seres em atividade, mediando e intermediando informações.

Aqui, o homem não mais age, apenas reage: reagimos por reação, tal qual Gregory Bateson definiria o laço social em seguida. Estabelece-se assim um estatuto antropológico equivalente para todos os seres comunicantes que operem segundo certo grau de complexidade. Máquinas, homens, quartos: todos podem ser compreendidos dentro das mesmas categorias comunicacionais. O debate sobre o indivíduo sai de cena e uma profusão de relatos permeados de encanto tecnológico toma a cena.

Esse golpe derradeiro no imperialismo antropocêntrico não afeta apenas o rescaldo humanista. Os devaneios ciborgues, a fetichização da tecnologia e a aceitação da técnica como uma finalidade em si mesma, bem como toda uma positividade que se quer imanente à tecnologia, são frutos do arcabouço conceitual que a discussão cibercultural é derivada. Trata-se de uma curiosa nivelação de tudo e todos à categoria de "parceiro comunicativo". Epistemologicamente, no entanto, retirar o homem do centro das relações sociais era uma ruptura importante, pois tal esvaziamento possibilitava relacionar e compreender as mediações comunicacionais como um fenômeno sistêmico da complexidade.

\section{INTERIORIDADE E EXTERIORIDADE}

O espaço para se compreender a individualidade, entretanto, ficara mais e mais reduzido, dado que o vínculo social de base deixara de existir e os próprios indivíduos passaram a ser meramente atores de uma cenografia mecânica. Ao se eliminar a categoria de sujeito também se suprimiu a especificidade individual, pois que tais seres trabalhados eram apenas reativos, e em nada muito criativos. $\mathrm{O}$ ranço funcionalista que marca a teoria dos sistemas de Talcott Parsons, delimitando o sujeito como mero organismo comportamental, tem como matriz teórica para as ações comunicacionais uma concepção cibernética químico-biológica. Dentro dessa perspectiva, toda atividade interior ao indivíduo, como sua experiência e vivência, é entendida como elemento irrelevante.

Esse é o problema de uma aceitação irrestrita da proposta teórica de Wiener, pois a interioridade do homem não precisa ser necessariamente humanista nem se remeter à metafísica. Pode-se ter em mente os processos internos de geração de sentido, um forjar de tecidos simbólicos que as manifestações literárias ou simplesmente escritas não podem abrir mão. A impossibilidade de uma compreensão puramente cibernética desse movimento se dá em razão de que os próprios elementos emergentes dos chats, criadores de outros círculos de significação, não se reduzem a um modelo funcionalista. Não se trata de retomar a suposta interioridade idealista do homem, elemento que se quer diferencialmente positivo em 
relação aos demais. Trata-se, nos termos de Deleuze, de atentar para a membrana (o sentido) que perpassa os "seres sociais", o fermento dessa relação: o sentido da comunicação.

O problema na concepção de "seres sociais" da cibernética é, em outras palavras, uma maneira excessiva de romper com o legado ontológico, resultando em uma deterioração de toda a dimensão cultural do processo comunicativo. O problema na concepção de indivíduo da cibernética é que, apesar de implementar um corte nas projeções iluministas que o conceito guardava, acaba por fazer do indivíduo uma categoria definhada e minúscula, imprestável.

A retomada da categoria do indivíduo, da menor unidade social, em uma perspectiva mais densa e teórica é por isso necessária ${ }^{10}$. Essa pesquisa se orientou por interrogações e reformulações sobre qual indivíduo poderia ser este, no mais das vezes corrigindo as suposições iniciais. Essa radiografia da escritura e da subjetivação cibercultural intenta, nos termos de Simmel, penetrar no significado íntimo da vida moderna e de seus produtos, penetrar na alma do corpo cultural, buscando resolver a equação entre os conteúdos individual e superindividual da vida ${ }^{11}$. A própria técnica de mapear os ajuntamentos de personalidade individual às forças externas e sociais é, no sentido referido por Bauman, relacionar a racionalidade de vida particular às formações sociais. Mas isso só pode ser feito se pudermos ver com alguma nitidez que interioridade é essa que reside em um chatter.

Não sendo um ortodoxo na tradição iluminista, é salutar que Walter Benjamin tenha se ocupado com a questão da experiência (Erfahrung) e da vivência (Erlebnis) ${ }^{12}$, considerando o esvaziamento atual operado nos elementos internos do "homem". Benjamin entendia que os canais para intensificação do relacionamento com o mundo, com "a carne do mundo", como diriam os fenomenólogos, perpassa uma maneira diferente de viver a arte, a filosofia, a literatura: de se expressar. Seria necessário, nestes termos, que uma nova forma de narratividade viesse à tona para reconstruir a dimensão da experiência (Erfahrung). Essa manifestação reconheceria a falência das tradicionais formas de experimentar o mundo - entendido como o perceber pré-moderno, de uma espontaneidade comunitária - mas também ultrapassaria o contentamento inerte do viver (erleben) privado, do individualismo vazio.

Essa expressividade poderia se fazer por meio de uma flutuação que sintetizasse as junções da experiência, tal como Benjamin sugere a respeito de Proust. Uma fina membrana em que a esfera do sensível se imiscui com o intelecto, movimento capaz de romper com a estase de um círculo de significações reiteradamente esvaziadas. A vida privada, a solidão da cidade e a impossibilidade de viver e compartilhar qualquer sentido poderia ser suplantada não pela lembrança - esta já irremediavelmente presa às armadilhas da tradição e da psique - mas por estratos que pudessem recriar as condições de uma outra objetividade corpórea, não-significada, e apartada do reinante subjetivismo que só fazia 
interiorizar. Trata-se de uma operação que procurar redescobrir a tessitura social por meio de explorações com a palavra, em intervenções que estabeleçam uma apreensão do universo sensível. Seria preciso, assim, encontrar novamente a voz da experiência pela qual estes indivíduos são.

Trata-se do embate entre o eu e o mundo que, nos termos kafkianos, é sempre vencido pelo segundo. A preocupação de Benjamin se dava com a redução no espectro da experiência, caracterizando o mundo vivido com uma fugacidade eminentemente superficial. Nestes termos, jamais tanta coisa havia sido vivida, mas a experiência seria cada vez mais rara. É curioso como os chats parecem incorporar uma outra corporeidade, agora imaterial e não-significada, num movimento que reiteradamente rompe com o círculo de significações estabelecido. Mas de maneira paradoxal, nestas salas de bate-papo é a vida privada que prevalece, apartada do espaço público, isso para não mencionar o fato de se fazerem por meio de uma palavra que é, ela mesma, uma imagem. Essa palavra-imagem, entretanto, é explorada por intervenções que não se estratificam nesse plano sensível, sugerindo desenhos sociais diferenciados, transversalmente virtuais. Em um período de vivência total, a voz da experiência parece de maneira paradoxal gritar a estes indivíduos quem eles são.

Paradoxal porque normalmente se entende que a experiência de que fala Benjamin requer que algo nos aconteça, que nos toque e nos modifique. Seria um gesto de interrupção, um gesto algo impossível nos tempos que correm. A experiência seria marcada por uma suspensão, um parar para pensar, olhar, escutar: mudar os andamentos e as velocidades do pensamento, a própria apreensão das coisas. O automatismo contemporâneo embruteceria a atenção e a delicadeza, todo o apanágio dos recursos perceptivos. Para Jorge Larrosa ${ }^{13}$, o sujeito da experiência se define não por sua velocidade - condição inescapável da contemporaneidade e essência do zapeador - mas por sua passividade, receptividade e disponibilidade. São essas características que marcariam o acontecimento ${ }^{14}$ e a experiência, e nenhuma delas faz parte do espectro da vivência. Mas em um universo de pura vivência, é razoável esperar que dimensões da experiência não desapareçam, mas assumam táticas internas de irrupção.

Verdade é que este debate não se desvincula das aporias da Modernidade, de como a experiência alargada (Erfahrung) poderia restaurar o sentido entre vivência individual e coletiva, investigando as relações entre memória e tempo e buscando trabalhar o material inconsciente que se liga às tradições, aos enredamentos sociais. Esse trabalho crítico, derradeira veleidade Moderna, entendia como possível fundar a experiência nos termos do sujeito iluminista, então o único elemento capaz de resgatar a experiência do novo. Mas o fato inelutável é que o sujeito se provou mero construto teórico datado, e caducou. Ainda assim, nem toda produção teórica girou em torno do sujeito, e o indivíduo não foi uma categoria inteiramente subutilizada. Um bom e luminar exemplo é o flanador francês, ícone da era moderna que ajuda em muito a entender as particularidades do caótico zapeador. 


\section{FLANAR E ZAPEAR}

Baudelaire fez da figura do flâneur um paradigma para o sujeito moderno. Tratava-se de um de um andamento muito particular, uma operação de apalpar a concretude moderna, então inverossímil. Como melhor modelo possível para o perceptum, o próprio poeta descreve sua vagabundagem pelos bulevares de Paris como uma exploração das gamas perceptivas da cidade. Isso se fazia pelo vagar errante, gracioso e fortuito que mantém a percepção aberta a experiências de toda ordem. Perder-se nas malhas urbanas ou, como prefere Maffesoli, deixar-se levar pelas vagabundagens iniciáticas ${ }^{15}$ constitui o cerne do flânerie ${ }^{16}$. A característica capital desse modelo citadino não se refere ao protótipo comum do burguês, mas a uma particular produção de sentido que a cidade possibilita ao indivíduo.

O flâneur reinventa a cidade em cada passeio, interpreta a infra-estrutura amealhada de qualquer significação para aqueles que não compreendiam suas peculiaridades, sua modernidade. O tecido urbano é grafado por um estriar singular, conjugando sua superfície e forjando um texto de significação privada. Seus estetas agem por apreensões individuais e nem mesmo suas remissões se dão coletivamente. A própria maneira de tecê-las: andar, apalpar, errar por caminhos não definidos define as categorias de apreensão pautadas por um ritmo próprio, que se preocupa tão somente com metáforas pessoais para a significação do espaço. Toma-se um local como seu, como propriedade particular: o sentimento de pertencimento é forjado por emulsões incoerentes que só se reúnem na unidade artificial do flanador ${ }^{17}$.

Nos afamados ensaios de Walter Benjamin sobre o flâneur ${ }^{18}$, sobretudo em Paris do Segundo Império, o autor descreve esse andarilho da cidade com certa ironia, em nada muito disfarçada. Benjamin direcionava sua verve contra uma literatura muito em voga na Paris da segunda metade do século XIX, que tratava de descrever os habitantes da cidade de uma maneira amistosa, pueril, familiarizando os cidadãos com os tipos diferentes que perambulavam pelas ruas, numa tentativa direta de dirimir as inquietações e medos com a metrópole. Essa literatura fisiologista objetivava ${ }^{19}$, diz Benjamin, dissolver o elemento estranho que a metrópole criava descontroladamente. O fundamental na descrição da flânerie, nos termos do ensaísta, não está nas tipificações de gêneros, ou na tal 'botânica do asfalto' como então a denominou. Isso porque o elemento que interessa ao filósofo é um desdobramento da narrativa baudelairiana, onde o conflito não é minimizado mas, pelo contrário, é o fio da estória. Não se procura apaziguar o conflito, mas tencionar, viver e conjugar a desordem.

A tensão dessa formação social, as contradições e ambigüidades que a cidade fez procriar, podem ser encontradas na abordagem seminal de Baudelaire ${ }^{20}$, cuja proposição narrativa lembra mais um devaneio 
que qualquer descrição explicativa. Em Baudelaire concentra-se a ambigüidade imanente do flâneur, na medida em que a assincronia existente entre a multidão e o indivíduo funda uma operação de recorte na cidade: atribui-se um sentido particular ao espaço público, sem proprietário. O gesto de flanar, aliás, constitui-se por si só em uma atitude de presença e ausência - simultaneamente - na aglomeração, pois insere o indivíduo na multidão ao mesmo tempo em que aprofunda sua solidão, seu isolamento da grande massa $^{21}$. É o turbilhão da cidade que, unindo todos os elementos, também aparta os sentidos de uns e de outros. Essa contradição permite ao flanador significar os espaços com um estilo não racionalista, quase um devaneio, tecendo uma subjetividade entre o passado e seus entrechoques: tal é a essência das forças modernas, tal é a complexidade de seu common $^{22}$.

Simmel, de maneira complementar, descreve a essência da urbanidade moderna como o blasé, a propriedade de não se deixar impressionar pelas diferenças abismais que a cidade proporciona: $a$ base psicológica do tipo metropolitano de individualidade consiste na intensificação dos estímulos nervosos, que resulta na alternação brusca e ininterrupta entre estímulos exteriores e interiores ${ }^{23}$. Há, para Simmel, uma diferença fundamental entre o homem rural e o urbano que diz respeito às condições psicológicas de cada $\mathrm{um}^{24}$ : a cidade imprime em seus habitantes grandes contrastes, traduzidos por imagens em mudança que convergem para uma única e mesma apreensão de impressões súbitas.

Essas condições materiais alteram os fundamentos sensoriais da vida psíquica. Atravessar a rua, comprar comida, pedir informação, requer um ritmo e especificidade de ações em muito alienígenas para os habitantes de cidade pequena e do espaço rural $^{25}$. A metrópole fratura o rito constante da aquisição de hábitos permanentes, típica da vida calma da cidade pequena. Para Simmel, a vida na metrópole exige de seus habitantes um uso exaustivo dos recursos cognitivos, dado que a mudança constante do espaço torna o uso do intelecto não uma opção, mas uma imposição. Na medida em que o intelecto é entendido como a mais adaptável das forças interiores, Simmel compreende o indivíduo da metrópole como alguém que se pauta pela racionalidade, com a cabeça, ao invés do coração ${ }^{26}$, pois não haveria recurso mais indicado que o intelecto para lidar com as contingências metropolitanas.

Quando a reação aos fenômenos metropolitanos é transferida para essa região "mais dura", o intelecto, o indivíduo se torna aparentemente mais frio, menos sensível às variações do ambiente e, em sua superfície, inacessível às regiões mais profundas da personalidade. A predominância da inteligência no homem metropolitano ${ }^{27}$, diz Simmel, endurece-o. De maneira paralela, a metrópole, como sede da economia monetária, concentra os câmbios econômicos que fundam um contrato de troca onde o lidar com homens é ineficiente e prosaico: lida-se com coisas. Todas as relações perpassam operações lógicas, e toda individualidade genuína é desprovida de consideração, dado que não é passível de mediação 
pecuniária. Para Simmel, a economia monetária e o domínio do intelecto são eventos intrinsecamente ligados, subproduto das aglomerações urbanas ${ }^{28}$.

Esses fatores que produziram exatidão e impessoalidade na vida ordinária também criaram uma subjetividade altamente singular que, para Simmel, é expresso pelo comportamento blasé ${ }^{29}$, fenômeno incondicionalmente reservado à metrópole. A atitude blasé seria o resultado de uma carga excessiva de estímulos contrastantes, em rápida mudança e compressão exagerada, gerando uma espécie de indiferenciação no indivíduo aos fenômenos externos: tudo soa parecido, desprovido de novidade. Seria desse esgotamento nervoso que emergiria a intelectualidade metropolitana, efetuada por uma perseguição desregrada ao prazer que agita os nervos até o limite de reatividade, até que parem de reagir. De maneira oposta, mas complementar, é também por meio da rapidez e incoerência nas mudanças que as impressões menos ofensivas podem originar reações inesperadas, violentas, estirando os nervos bruscamente em outra direção até suas últimas reservas se exaurirem. O blasé é, assim, a incapacidade emocional de reagir a novas sensações com a energia que se esperaria: não há surpresa para esse indivíduo.

Do blasé e do flâneur à atualidade, há uma espécie de linha contígua caracterizada pelo provimento ininterrupto de independência da esfera individual e, portanto, da individualidade ${ }^{30}$. Ao mesmo tempo, há um esvaziamento da esfera pública, ou sua refeudalização, em termos habermasianos. Piorando, ocorre que o flâneur e o blasé encontram-se em tal medida hiper-acelerados, desenvolvidos, que a metáfora televisiva do agente com seu controle remoto parece, ainda que grosseiramente, mais exata. Com a virtualização que o ciberespaço funda e a tudo abraça, não há mais um único espaço citadino referencial para se apalpar, para se flanar, mas antes um imaginário imagético para se imergir, para se zapear. Em tudo que a abordagem seminal de Baudelaire do indivíduo moderno tem de relevante para um resgate da dimensão individual, ela também tem de irrelevante quando consideradas suas diferenças para com as práticas contemporâneas.

O flanador opera por meio de insights sobre a modernidade urbana. Com uma imaginação portentosa, ele penetra no sentido oculto para além da aparência das mercadorias e objetos. Seria um tipo capaz de estabelecer conexões desconhecidas, ter percepções incomuns, forjando todo um mundo de palavras, reflexões e sentimentos. A metáfora perfeita para o flanador é a da cidade como um texto, e o flâneur como um leitor. É precisamente essa metáfora que não encontra mais ressonância na individualidade contemporânea $^{31}$. Na atual geografia urbana, com seus espaços esquizofrenicamente justapostos, conjugados paralelamente e ignorados mutuamente, não há o que se ler ou escrever. Há materiais a serem “juntados”, tão somente imagens. 
Os sentidos são então demarcados individualmente, não havendo um princípio público ou universal. Os objetos não possuem significados necessários ou pré-definidos. É um liame onde o sentido parece avulso aos objetos, prontos para um "faça você mesmo" ou "entenda você mesmo". Não há aquela compleição histórica e tradicional nas matérias do cotidiano, essa é a contribuição pós-moderna à universalidade. Em oposição a essa individualidade onipresente, o flanador compunha-se a si mesmo sempre de fora para dentro, e ainda que se deslocasse por um eu descentralizado que multiplicava as intensidades, esse tipo particular absorvia o espaço oscilando de uma vaporização para uma nova centralização do eu, como que por círculos concêntricos - e não por espirais e mais espirais, tal como o zapeador o faz. $\mathrm{O}$ vitalismo do movimento pode ser semelhante, mas a pulsação contemporânea é mais maligna que benigna ${ }^{32}$.

E não se pode perder de vista que caminhamos rumo a um perfeito energúmeno digital, mais do que a qualquer saber digital, a despeito das suposições sobre uma inteligência coletiva ou uma individualidade esclarecida emergente, de que se faz tanta propaganda. Na teia de informação infinita, o que temos é antes um ignoto que não compreende o que copia de sites, possuidor de um despreparo que beira a psicose instrumentalizada. Valendo-se de posturas antagônicas, apresenta textos informativos (que corta e cola de sites escolhidos a esmo) sem compreender o conteúdo oferecido, ou o compreende de maneira patentemente contraditória ${ }^{33}$.

Esse energúmeno digital duvida de tudo e não quer conhecer a tradição escrita, que menospreza. A individualidade digital não é intrinsecamente positiva, e sua operacionalidade não deve ser confundida com o do cético: esse zapeador eletrônico não crê em nada porque o sentido que estabelece para as coisas é exclusivamente individual. Encantado por simulacros, sua referência é a falta de referência, a ausência de pólos ordenadores. Duvida das fontes que embasam a ciência e a filosofia, relativizando até as tragédias de memória mais funesta ${ }^{34}$. Apartado de qualquer conexão referencial com o acontecimento factual, pede as contas de cada vítima da história.

Baudrillard anotou que a Guerra do Golfo não existiu ${ }^{35}$, declaração que pode ser entendida como se houvesse duas guerras: a existente e aquela televisionada. Mas a segunda é mais significativa, pois mais pessoas acreditam nela. Também por isso é mais real. O sangue e as mutilações da guerra real, que nem os soldados americanos presenciaram, não são tão reais quanto a onipresença da guerra televisionada, essa familiar guerra que conhecemos pois vimos na TV. Em mais um paradoxo, a guerra virtual é "mais real" que a guerra efetivamente experimentada; as interpretações e entendimentos que o incauto faz dos fatos - no mais, mediados por telejornais e fontes que já são em si mesmas eletrônicas e "irreais" - são para ele invariáveis e idênticas entre si: uma interpretação é tão válida quanto qualquer outra. 
Não existe credibilidade, nem mesmo matizada, no universo desse energúmeno digital. Suspeita-se de tudo, pois acontecimentos reportados são idênticos entre si, são construções narrativas que reportam um evento oco. Qualquer discurso é possível, pois remete à posição do enunciador e não às particularidades do objeto. Não haveria diferença fundamental entre porta-vozes do governo, de Organizações NãoGovernamentais ou de empresas de comunicação, o entendimento sobre fatos fica reduzido ao eu acho, pois toda assunção é virtual e só responde à sua própria lógica discursiva. É o perverso anúncio de que não há verdades, e que o consenso, o entendimento mútuo e o consentimento sobre valores e fatos não é factível. Mas não compreendamos mal o energúmeno digital: não é que ele não compreende a lógica do simulacro, ele a compreende imediatamente. Apenas duvida que exista qualquer coisa além do simulacro. É como se uma desconstrução fosse levada até as últimas conseqüências, mas tanto nas possibilidades de compreensão de um acontecimento como em seu inverso total: a relativização de tudo, o esvaziamento ${ }^{36}$, o desinvestimento de importância sobre todo o conhecimento. Confundem informação com conhecimento e pedem o incompreensivel, o absurdo, anotou Deleuze ${ }^{37}$.

É tal a condição deste agente, o zapeador, um modelo algo tacanho mas condizente com a prática dos chats. Mesmo a suposição de que possa haver um "modelo" é apenas parcialmente aceitável, na medida em que trabalha-se com indivíduos que só grosseiramente podem ser entendidos dentro de um escopo generalizante $^{38}$. Do cinema às lan houses ${ }^{39}$, dos grupos restritos de pichadores às irmandades igualmente fechadas do mundo hip-hop, a imanência que rege a ordem social é inteiramente individual, inescrutável para qualquer palavra de ordem ou orientação metapolítica. A inserção que tais grupos fazem na dinâmica social é absolutamente impossível de ser entendida separada dos próprios códigos e signos que o grupo cria - tão somente para seus próprios membros.

No blasé de que falava Simmel existe um embrutecimento permanente dos sentidos, resultado dos processos de urbanização e modernização. Essa intensificação da individualidade de que o blasé é fruto e o flanador, ícone, criou essas duas figuras em alguma medida opostas. Mas o processo formador dessas identidades é o mesmo que traz o termo da experiência (Erfahrung): a modernidade. Trata-se de um crescimento contínuo no espectro de vivências (Erlebnis) a ponto de as experiências mesmas não serem mais compartilháveis e por isso, incomunicáveis. O blasé não é senão um indivíduo que aceita sua impotência em transmitir a gama de percepções cotidianas com acuidade, se fechando em sua mônada de apreensões, seu cockpit para experimentações metropolitanas ${ }^{40}$. O flanador, cuja particularidade remonta a experimentações com o sentir, passeia pela cidade e recorta pedaços para injetar-lhes um sentido em todos os níveis pessoal e intransferível.

O que o zapeador tem de semelhante, mas também de diferente em relação aos tipos modernos, é a plena consciência da impossibilidade de se transmitir qualquer apreensão pessoal em sua inteireza. Não haveria 
uma tragédia pessoal a se relatar, pois o enredo comunicacional estilhaçou-se. O zapeador, afogado em referências que são pessoais, engole partes e retalhos do ambiente exterior que lhe interessa enquanto ignora a coesão ampla de sentido que ali supostamente haveria. Ou pelo menos deveria haver. Opera cortes e extrações na paisagem, totalmente descomprometido com a ela.

Não é diferente com os chats. O que eles fazem ver é o instante em que essa formação subjetiva começa a se engendrar a si mesma - o zapping desvinculando-se de um particular agenciamento tecnológico para uma máquina produtora de subjetividade, procriando: não mais uma mera sensibilidade hiper-acelerada. Os nicks dos chats - que podem ser muitos para cada indivíduo - são como partes descoladas de uma individualidade despreocupada não só com a suposta identidade pessoal, mas com toda a extensão implacável da realidade. Há um niilismo ou um escapismo permanente, onde se funda uma maneira de apreender o espaço que se faz não por adição ou divisão, como nas bricolagens, mas por subtração e multiplicação. O zapeador é um agenciamento subjetivo que não apenas retira do todo, partes. Ele descola qualquer enquadramento de sua totalidade, desloca uma construção assentada para uma ruína que lhe possa interessar. Como um nômade, só os pedaços lhe interessam e qualquer suposta inteireza ou plenitude é um devaneio falso e inverossímil.

Não se flana a hiper-tela, imerge-se nela. De maneira extensiva, as camadas do espaço urbano passam a ser editadas por um zapping intermitente. A tessitura social da contemporaneidade é moldada por uma composição espacial de junções paradoxais, com seus não-lugares, espaços vazios e locais de passagem: Fim do flanador, sobreposto à outra configuração, não a do olhar que contempla e que se deixa seduzir. Mas a do olhar que filma de forma fugaz, passageira, invisível. Veloz. Do olhar que escaneia. Que atravessa $^{41}$.

\section{ZAPPING}

É curioso como em uma era de conectividade total, a figura semântica que melhor traduza essa máquina de agenciamentos que o zapeador é seja a de desconexão. É como se toda a experiência, e o próprio estar no mundo vivido se dessem por fragmentos, rechaçando as técnicas de contemplação. Observações são feitas aos pedaços, por retalhos recolhidos em alta-velocidade. Há toda uma precariedade nessa maneira de operar que estranhamente não causa qualquer aborrecimento. Um zapeador, tal como o chatter, vive em um exílio pessoal feito de pedaços, um quebra-cabeça sem origem nem futuro. E é com esses pedaços que deverão encontrar sentido e desvendar quem são, pois a memória não os governa mais. 
Isso fica mais claro quando se tem em mente que tal conectividade é forjada em uma distância espacial entre os interagentes, sendo assim uma comunicação desprovida de verificação químico-biológica, próprio aos mamíferos. Uma comunicação que não se acanha com distâncias territoriais, tecida por pontos que se ligam a outros pontos mas que não podem abarcar qualquer união ${ }^{42}$. São portanto sempre parciais, e seus clipes contornam uma realidade preferencial ou suportável. Em caso de estorvo, miséria, segregação ou racismo, qualquer memória de uma discussão desagradável, muda-se de canal. Os marginalizados de toda sorte que se apercebam com a mesma rapidez com que são remanejados: a eliminação das categorias de excluídos nesta dinâmica é simples. Basta que não constem, basta que a edição os corte. Quem irá perceber o descarte dos descartados?

Naturalmente, as edições e montagens do zapping ficam a encargo de cada zapeador. Mas a lógica dessa programação é a de que aquilo que não interessa, não é apenas desinteressante. Passa a não existir, ou então que vá existir em outras bandas - não nesta. Não há desperdício de banda algum, apenas o interessante a mim deve fluir. Essa nova variável, perversa, é a de um olhar fartamente aberto, porém enclausurado. Um império do sentir radicalmente modelável pelos conteúdos imaginários que cada zapeador escolhe para seu universo.

Funciona como um clipping constante: ou seja, recortar e colar coisas. Juntá-las, tentar rechear com algum sentido, provavelmente arbitrário. Variações e conjugações de uma conversa que não dialoga. Em canais aleatórios encontram-se estranhamentos e manifestações de patente criatividade. Numa rápida leitura lêem-se frases desconexas, cuja investigação pelo sentido nas trilhas que correm é difícil. Em casos como este, melhor fazer mais uma conexão, mais um zapping. Isso porque estas frases não foram apenas e propositalmente retiradas de seu contexto. Elas não têm contexto, embora também não sejam o fruto perfeito de um oceano de diálogos vazios ${ }^{43}$. As frases pelos chats afora devem ser auto-suficientes, caucionadas no desejo de se fazer comunicável, de estabelecer algum laço virtual ${ }^{44}$.

Decerto os chats não inventam esses fluxos ininterruptos de imagens, que estão, de resto, disseminados por todo o circuito social. Mas encontramos aí uma das mais bem acabadas máquinas de geração de enredos comunicacionais, de produção de fantasia e, por extensão, de real. Talvez melhor fosse dizer um hiper-real, a escorrer da vida a partir dos monitores, rendendo todos os participantes a uma indistinção entre a imagem e realidade. O termo "cultura visual" procura indicar um modelo de cognição e subjetividade, mas o que se pôde observar aqui, é a produção de "tipos sociais" que incorporam na discursividade a substituição da realidade por uma imagem da realidade. São como fábulas, contos visuais que compõem uma população de elementos inconscientes e particulares ao zapping ${ }^{45}$. 
Os riscos e derivações que a indistinção contemporânea entre imagem e realidade - ou reflexo e coisa em si - produz, foram prodigamente trabalhados pela literatura. Em Cidades Invisíveis, Ítalo Calvino descreve a cidade de Valdrada, lugar repleto de casas com detalhes e ambientes sobrepostos. Construída à beira de um lago, a água toma conta do nível logo abaixo da rua. Assim, aquele que olha a cidade vê na verdade duas: uma sobre o lago e a outra refletida de cabeça para baixo. Calvino salienta que tudo que ocorre em uma, acontece na outra, inclusive a vida recôndita dos quartos fechados e dos becos esquecidos, porque a cidade foi construída de tal modo que cada um de seus pontos fosse refletido por seu espelho ${ }^{46}$. Tudo em Valdrada se reflete, todo acontecimento é reflexo daquele outro.

Calvino diz que a vida dos habitantes é tomada por uma lógica anormal, pois sabem que seus atos são simultaneamente dois, o ato mesmo e sua imagem especular; consciência que os impedem de viver livremente, descansadamente, de se abandonarem ao acaso por um só instante ${ }^{47}$. O reflexo permanente da ação congela os habitantes em um presente contínuo, eternizado e de onde não podem escapar sob o risco de a imagem os devorar. A parábola, simples, explica a condição do zapeador em toda sua inteireza: a imagem é uma sedução de que não se pode escapar, pois ela aprisiona o indivíduo não dentro de limites espaciais, mas imaginários.

Petrificados, Calvino ainda diz que às vezes o espelho aumenta o valor das coisas, e outras vezes as anula. Mas nem tudo o que parece valer acima do espelho resiste a si próprio refletido no espelho ${ }^{48}$. Como no mito da medusa, cujo simples olhar transforma observador em pedra, o espelho congela a imagem em seu próprio universo imaginário. As duas cidades, tanto Valdrada quanto sua imagem especular, não são a mesma coisa, mesmo porque são diametralmente opostas em seu grafismo visual. Mas a consciência de que todo gesto se reflete as paralisa, fazendo as duas Valdradas viverem uma pra a outra, olhando-se nos olhos continuamente, mas sem se amar ${ }^{49}$.

Falamos em zapping, aliás, menos como resultado da referência onipresente da televisão do que de um particular estilo de montagem e decupagem que lhe é parte integrante: o videoclipe ${ }^{50}$. Esta foi a analogia mais próxima da linguagem nas salas de bate-papo, na medida em que suas imagens-texto se encadeiam através da rotação interminável dos elementos em que tudo é desalojado no momento seguinte, aparentando um jogo límpido de alternância de significantes. É uma comunicação escrita com um estilo de corte sincopado, cheio das repetições e movimentos curtos, tal como um clipe, com suas elipses de tempo, olhar subjetivo e rastreador (uma câmera que nos chats é uma narrativa), remontando à melhor tradição de Diziga Vertov, com seus planos quase subliminares de poucos frames.

A coerência desse contexto em que grandes narrativas são desmontadas pode ser encontrada no uso simultâneo de múltiplos presentes ${ }^{51}$, em uma conjunção em muito próxima daquilo que Lacan chamaria 
de ruptura na cadeia dos significantes, ou seja, a condição do esquizofrênico. Não por menos a incapacidade do esquizofrênico em unificar passado, presente e futuro em uma sentença remonta ao curioso processo de estilhaçamento dessas dimensões na atípica cronologia atual, assim como ajuda a entender a falta de relações explicativas para a vida psíquica contemporânea, invariavelmente combatida com seus remédios para toda dor. Se a fragmentação é uma condição tal como dantes fora a coerência linear, natural que as psicopatologias do ego dêem lugar a distúrbios mentais inexatos, associados à autodestruição e à esquizofrenia. Esse presente contínuo que se vive nas e pelas imagens pode simular qualquer estilo, mas o sentido de realidades presentes ou passadas não pode ser simulado.

Seria uma questão insolúvel investigar o surgimento desse presente contínuo na contemporaneidade. Decerto o império da imagem, sobrepondo a tradição e o legado imemorial da escrita, contribui para o esfacelamento das heranças linearmente acumuladas, escritas. Mas o próprio esquecimento do passado e do futuro, transformando o presente em um estado contínuo e eterno, não pode ser descuidado como força que engendra a sensibilidade do zapping e a instauração do império imagético. Sobretudo, o fosso irreconhecível que bóia entre o passado e o futuro é uma questão tão contemporânea quanto moderna, como já anotou Hannah Arendt:

O testamento, dizendo ao herdeiro o que será seu de direito, lega posses do passado para um futuro. Sem testamento, ou, resolvendo a metáfora, sem tradição - que selecione e nomeie, que transmita e preserve, que indique onde se encontram os tesouros e qual o seu valor - parece não haver nenhuma continuidade consciente no tempo, e portanto, humanamente falando, nem passado nem futuro, mas tão somente a sempiterna mudança do mundo e o ciclo biológico das criaturas que nele vivem. ${ }^{52}$

Esse fosso não identificável entre o que passa e o que virá a passar não é apenas o presente entendido como cronologia fixa. Lembra mais a duração a que Bergson fazia referência, espécie de imersão profunda em um tempo que se prolonga sobre si mesmo, ad infinitum, como nos fractais. Um segundo que se dilata interminavelmente, vivido como horas intermináveis. A imersão zapeadora está em tal medida descolada da herança escrita que não questiona pressupostos, como seria de se esperar de um modelo herdeiro da tradição do grafo. Por isso, não relembra nem pensa sobre a memória, espécie de pesadelo vivido kafkiano onde a memória é gravada em imensos discos eletromagnéticos para ser então esquecida, inutilizada.

Essa tragédia - ou comédia, alguém poderia aventar - começa quando as marcas que um acontecimento vivido deveria ter na mente dos que contarão a história, transmitindo seu significado à posterioridade, se esvai. Nos termos de Benjamin, é quando a experiência sai de cena e a vivência se torna global. Sem essa preparação ritualística entre sentidos recebidos e transmitidos, sem a articulação realizada pela memória, 
simplesmente não é possível uma história ser contada de maneira viva e experimentada. E isso afeta não apenas a forma de contar uma história, mas sua definição mesma.

Pois se falamos tanto em espirais e círculos crescentes, como Rainer Maria Rilke gostava de definir sua $v_{\text {vida }}^{53}$, é porque o desenho de uma cronologia linear, uma linha progressiva que parte do passado rumo ao futuro, com um "meio" que se entende ser o presente, é pobre em representar as forças do tempo a que nos referimos. Pois ao mesmo tempo em que há uma seta ou linha na horizontal - a cronologia -, há também uma diagonal, em rumo incerto para o infinito, mas irrevogavelmente presa ao ponto de que parte, a seu eixo. Ou seja, ao presente.

O zapeador é o pobre-diabo arraigado a esta linha diagonal que, mesmo se deslocando velozmente para cima e para baixo em sua perpendicular de distância infinita, não consegue se mover na linha horizontal da cronologia, a linha do passado e do futuro. Não pode, com isso, mudar a direção a partir da qual poderia ver e entender adequadamente aquilo que lhe concerne e lhe origina, ou seja, a dimensão anterior e posterior do tempo. Natural que tais dimensões só possam existir com o aparecimento deste ponto presente, mas essas dimensões ou forças do passado e do futuro parecem ter entrado em um lugar no tempo suficientemente afastado para oferecer ao peregrino da imagem qualquer posição de observador, qualquer posto de observação de onde julgar com imparcialidade e compaixão as forças que se digladiam $^{54}$.

O lugar do presente, se pudéssemos fazer uso de uma metáfora espacial para um objeto temporal, não tem na verdade um tempo definido, não é nem histórico nem a-histórico, é intemporal, pois está no âmago mesmo do tempo, ou melhor dizendo, da duração. Não é por isso algo que se herda como o são a cultura e a língua em que nascemos. O passado apenas pode indicar esse locus, mas cada geração ou cada indivíduo deve encontrar esse lugar indefinível entre um passado e um futuro infinitos. Cabe a cada um descobrir a imanência irredutível de seu presente, e assim pavimentá-lo uma vez mais.

O problema é que, como coloca Hannah Arendt, parece que não estamos mais equipados nem preparados para essa atividade de repensar ou refazer nosso eixo. Instalar-se na lacuna entre o passado e o futuro exige certos recursos que a modernidade faz escassear cada vez mais. Por longos períodos da história, na verdade no transcurso dos milênios que se seguiram à fundação de Roma e que foram determinados por conceitos romanos, esta lacuna foi transposta por aquilo que, desde os romanos, chamamos de tradição. Não é segredo para ninguém o fato de essa tradição ter-se esgarçado cada vez mais à medida que a época moderna progrediu ${ }^{55}$. E se o fio da tradição se rompe, se a escrita é substancialmente substituída por composições imagéticas, refazer o eixo dessa lacuna entre o passado e o futuro deixa de 
ser uma contingência necessária àqueles que pensam sua vida. Não é só a percepção da realidade tangível que se estilhaça, mas todo o ferramental utilizado para criar a sensação de unidade.

É entretanto necessário sair do primado iluminista para entender com mais propriedade onde estão estes indivíduos. Havia no sujeito da tradição humanista uma combinação de clarividência e impotência, que parece ter adquirido feições exatamente opostas nos dias que correm. Kafka, ao descrever a experiência do pensamento moderno, escreve sobre uma consciência que percebe toda a extensão da maquinaria industrial moderna, ao mesmo passo que é completamente impossibilitada de atuar sobre ela. Vê e conhece seu tempo, mas é impotente diante dele. Um zapeador age de maneira perfeitamente contrária: ignora inteiramente seu tempo, é mesmo incapaz de lhe compreender, mas age sobre ele cegamente, sem muita ponderação.

O sujeito moderno, basicamente fundado na dicotomia entre ser e apreender fundada por Descartes, vivencia o choque entre passado e futuro, observa e analisa seu lugar na coerência do tempo (Zeitgeist) mas nada pode fazer neste mundo grande demais. Não por menos, o flanador é um observador viajante que pode ver toda sorte de manifestação, mas não pode atuar nelas. O zapeador a que aqui se faz referência, onde a memória e a tradição são suspensas, já não prevê movimento algum, nem tampouco lhe compreende em sua inteireza. Não apenas não entende o passado como também, por certo como resultante, ignora o futuro. Não é um agente da história, entendida como processo de construção de realidades, pois esse agente ignora não só processos, mas também realidades. Assim, em nada se assemelha ao agente consciente e lúcido cultivado pela tradição iluminista, ansiosa por atualizar e aperfeiçoar as heranças e religiosidades que sua historicidade específica lhe atribuía.

O paradoxo é que o zapeador é tão ignorante quanto a seu papel histórico quanto é poderoso em relação a ele $^{56}$. Sem entendê-lo em sua processualidade, e perdido na duração infinita de um presente perdido, atua em seu mundo todo o tempo, fechado em um isolamento apenas semanticamente inócuo. Ainda que estejam fechados e isolados, essas mônodas individuais têm enorme poder de ação, como demonstra toda a vitalidade do mundo cibercultural. À evasão do sentido teleológico da ação, percebe-se que diante da impossibilidade de compreender, é dada a possibilidade de agir. Não um agir coordenado por programas, mas um agir que é fartamente esquizofrênico, sem direção e quiçá sem sentido. Marx sabia que a História não carece de ironia e, assim sendo, parece que quanto menos entendemos o mundo, mais o alteramos.

O que os circuitos eletrônicos estão fazendo é desbloquear a contenção de uma represa de identidades arruinadas, vendidas agora a preço tão baixo que qualquer um pode ter muitas. O fluído está presente até mesmo na identidade mais sólida, pois a nova eletrônica termina de apodrecer a velha confiança na natureza da identidade. Quando a particularidade irredutível do indivíduo é relativizada, tornamos-nos 
todos unidades de retro-alimentação relacional entre arranjos de reflexão e refração. Para uma geração em que as certezas e a estabilidade, sobretudo de emprego, parecem características de um inalcançável passado, e cujas famílias nucleares cada vez mais carecem de núcleo, o escapismo, a atividade de se deixar levar por fantasias ciberespaço afora é um júbilo que o corpo social não pode mais abrir mão. Isso coloca a geração cibercultural, do zapping, como a primeira a ter uma matriz de realidade inteiramente imaterial, imaginativa, e por decorrência, auto-referencial.

Zapeia-se o mundo não para fugir dele, mas para fazer o mundo caber em nós. Não é a tentativa de fugir de uma realidade insuportável, mas seu contrário, a de imputar razão e lógica a um mundo que já não oferece qualquer unidade de sentido. De uma função antes antagônica, o escapismo surge como uma máquina de produção de realidade. Uma vez mais a ironia.

\section{NOTAS}

${ }^{1}$ Bauman, Zygmunt. A Sociedade Líquida. Entrevista cedida ao Jornal Folha de São Paulo, Caderno Mais!, Domingo, 19/10/2003, (p.6).

${ }^{2}$ Baudrillard, Jean. A Transparência do Mal: ensaio sobre os fenômenos extremos. Campinas: Papirus, 2003, (p.11-12).

${ }^{3}$ Ciro Marcondes Filho comenta as anotações que Flusser fez a respeito da mudança no código dominante na história da comunicação: "A filosofia para Flusser não poderia mais proceder de forma discursiva, ela teria que se adequar aos novos tempos da imagem. (...) A filosofia mediática deveria ser agora um filosofar com os meios de comunicação. Flusser vai dizer, em seu Elogio da Superficialidade, que nós não percebemos a realidade mas, antes, que a construímos, ou então, que processamos o percebido como realidade. (...) Na Kommunikologie, ele diz que os códigos técnicos serão as 'línguas escritas' do futuro, decifráveis sem a necessidade de um texto que as informe. Imagens que de forma alguma significam o mesmo que o ideograma de um veículo, mas, antes, derivam do alfabeto e trazem consigo a estrutura de um texto. São imagens mediadas por textos que não transmitem textos; são línguas escritas mas não como línguas faladas transcritas alfabeticamente, mas como línguas que significam em imagens todos os textos escritos possíveis, línguas, cujo código não é a escrita mas seu significado." Marcondes Filho, Ciro. O Princípio da Razão Durante. Trabalho de circulação restrita, 2005.

${ }^{4}$ Ver a este respeito a vigésima sétima nota de rodapé do capitulo Linguagem Carne Cor De Plástico.

${ }^{5}$ Para além da exegese marxista de ver nas contradições sociais o fulcro de seu sentido, há essa assunção de Bauman, decerto mais objetiva conquanto mais primitiva: "Cada formação social promove seu próprio tipo de racionalidade, investe seu próprio significado na idéia de uma estratégia racional de vida.” Bauman, Zygmunt. Modernidade Líquida. Rio de Janeiro: Jorge Zahar, 2001. (p.125).

${ }^{6}$ Cabeçalho de uma discussão, trilha por onde um assunto se origina e segue adiante. Em uma troca de e-mails, o thread é o assunto que dá início à discussão e que aparece indicado no campo "assunto" (subject) da mensagem.

${ }^{7}$ Fragmentos de cadernos e folhas soltas, sem data. IN: Kafka, Franz. Sonhos. São Paulo: Iluminuras, 2003. (p.141).

${ }^{8}$ Sobre esta questão, Flusser faz um interessante paralelo entre as descobertas da física de Maxwell e Faraday e o próprio entendimento de individualidade. Comentando o fim da crença na existência de uma partícula material última na natureza, seja o ar, a água, o fogo, os números ou mesmo os átomos, Flusser diz que aí o pensamento operou uma virada epistemológica 
revolucionária. À suposição de que algo deveria compreender a matéria original, responsável pela formação de todas as outras, a ruptura de Faraday e Maxwell explica que nada disso existe, mas apenas campos eletromagnéticos. Assim, toda a materialidade é fundamentalmente uma construção perceptiva. “A partir daí, Flusser deduz que não encerramos dentro de nós nenhum núcleo sólido, nenhuma identidade, nenhum ego, espírito ou alma. Ao contrário, estamos imersos num campo psíquico coletivo do qual aparecemos como bolhas provisórias que adquirem, processam e repassam informações para logo depois submergirem novamente". Ou seja, estes personagens espocam de um lado a outro e qualquer identidade unitária, ou mesmo qualquer individualidade soberana, é entendida de maneira relacional e temporária. A esse respeito, ver: Marcondes Filho, Ciro. O Princípio da Razão Durante. Trabalho de circulação restrita, 2005.

${ }^{9}$ Wiener, Norbert. Cibernética e Sociedade - O uso humano dos seres humanos. São Paulo: Cultrix, $3^{\mathrm{a}}$ edição., s/d.

${ }^{10}$ Sobre esse agente que não é sujeito, mas que não deveria ser tratado como mero indivíduo, Antonio Negri tem um conceito interessante, embora ainda marcado por certa teleologia e utilitarismo de tradição marxista. Negri fala em multidões, e não esconde ver nesse conglomerado de indivíduos uma vocação revolucionária. Infelizmente, trata-se de um conceito ainda pouco definido, poroso, que cede aos usuais floreios do idealismo romântico. Assim, a multidão de Negri guarda uma incrível potência para amar, transformar o mundo e viver com amor. A marca da emancipação, ou a procura pela emancipação, é perene. Piorando, talvez seja o caso de apontar que a admirável proposta de Negri se trai em seu pressuposto primeiro, pois persegue uma definição última por meio de operações conceituais unificadoras, bastante comuns à sociologia dos macrofenômenos. Isso tudo enquanto a dinâmica social que lhe serve de objeto é por excelência a do movimento e do fluxo. Ou seja, ainda que o autor procure denominar e circunscrever esses agentes sociais, o faz por meio de um esquema que inviabiliza o lidar com suas características mais vigorosas: seu caráter descentrado e arborescente, dificilmente apto a ser tratado pelas lentes agigantadas da sociologia. Ver a este respeito, Negri, Antonio. Cinco lições sobre o Império. Rio de Janeiro, DP\&A, 2003. Sobretudo a questão de Danilo Zolo à página 42-45. Ver também: Negri, Antonio e Hardt, Michael. Multitude: War and Democracy in the Age of Empire. London: Penguin Press, 2004. Outro autor que procura trabalhar conceitualmente o indivíduo é Manuel Castells, qualificando a Internet como um ambiente onde o individualismo se estabelece como forma dominante de sociabilidade. Castells não entende o individualismo como força anti-social, oposto às interação da vida social. O padrão de sociabilidade que Castells trabalha - e que diz ser "específico" - é baseado em um conceito algo contraditório: individualismo em rede. Seriam aqueles indivíduos que utilizam a grande rede como ferramenta de contato com diferentes universos, mas também como ferramenta de reforço dos contatos reais. Em termos práticos, Castells quer dizer que os indivíduos na rede não são "nerds", mas "geeks". Ver a esse respeito: Castells, Manuel. A Galáxia da Internet. Rio de Janeiro: Jorge Zahar, 2003.

${ }^{11}$ Simmel, Georg. A metrópole e a vida mental. IN: Velho, Otavio (org). O Fenômeno Urbano. Rio de Janeiro: Jorge Zahar, 1967. (p.14). A questão sobre a importância de se trabalhar a dimensão individual e as micromanifestações da sociedade perfaz toda a obra de Simmel, antes mesmo da virada do século XX. Aparece bem resumida neste trecho: "A escala dos valores humanos já não é constituída pelo 'ser humano geral' em cada indivíduo, mas antes pela unicidade e insubstitubilidade qualitativas do homem. A história externa e interna de nosso tempo segue seu curso no interior da luta e nos entrelaçamentos em mudança dessas duas maneiras de definir o papel do indivíduo no todo da sociedade. É função da metrópole fornecer a arena para este combate e a reconciliação dos combatentes." Idem, (p.27)

${ }^{12}$ A oposição que Benjamin traça entre experiência e vivência é rapidamente tratada aqui: "Este ensaio de Benjamin se baseia na oposição em Erfahrung e Erlebnis, aqui traduzidas respectivamente como 'experiência' (real ou acumulada, sem intervenção da consciência) e 'vivência' (experiência vivida, evento assistido pela consciência). Diz ainda Leandro Konder: Erfahrung é o conhecimento obtido através de uma experiência que se acumula, que se prolonga, que se desdobra, como uma viagem; o sujeito integrado numa comunidade dispõe de critérios que lhe permitem ir sedimentando as coisas com o tempo. Erlebnis é a vivência do indivíduo privado, isolado, é a impressão forte, que precisa ser assimilada às pressas, que produz efeitos imediatos.” Benjamin, Walter. Charles Baudelaire - Um lírico no auge do capitalismo. Obras Completas III. São Paulo: Brasiliense, 1994. (p.146, nota $\left.\mathrm{n}^{\circ} 12\right)$.

${ }^{13}$ Larrosa, Jorge. Notas sobre a experiência o saber da experiência. Tradução de João Wanderley Geraldi. Conferência proferida no I Seminário Internacional de Educação de Campinas, Unicamp.

${ }^{14}$ Essa disponibilidade fundamental é orquestrada por uma abertura essencial que altera a relação contemporânea de vivencia vazia de experiência. Nos termos heideggerianos, um acontecimento, tal como o autor trabalha: "fazer uma experiência com algo significa que algo nos acontece, nos alcança; que se apodera de nós, que nos tomba e nos transforma. Quando falamos em 'fazer' uma experiência isso não significa precisamente que nós a façamos acontecer, 'fazer' significa aqui: sofrer, padecer, tomar o que nos alcança receptivamente, aceitar, à medida que nos submetemos a algo. Fazer uma experiência quer dizer, portanto, deixar-nos abordar em nós próprios pelo que nos interpela, entrando e submetendo-nos a isso. Podemos ser assim transformados por tais experiências, de um dia para o outro ou no transcurso do tempo." Heidegger, Martin. APUD: Larrosa, Jorge, Idem.

${ }^{15}$ Tal é, também, a acepção que André Lemos utiliza para trabalhar o tema. Ver: Lemos, André. Ciber-Flânerie. IN: Fragoso, Suely \& Da Silva, Dinorá Fraga. Comunicação na cibercultura. São Leopoldo: Unisinos, 2001. (p.45-46).

${ }^{16}$ Termo que designa, e não por acaso, algo ou alguém inoperante; pessoa que não trabalha; sem valor; preguiçosa; algo ocioso, sem propósito e que fica "à toa"; desempregado ou aquele que "mata o tempo"; desocupado. A oitava edição do dicionário da Academia Francesa (de 1932-35, quando a primeira edição data de 1694), entrementes, já incorporava as definições de 'flânerie' como 'ato de passear' e 'flâneur' como 'aquilo ou aquele que passeia' e ainda 'flânocher, aquele ou aquilo que passeia calmamente'. A indicada $8^{\circ}$ edição do Dicionário da Academia Francesa contava, no momento de sua publicação logo após a II Guerra Mundial, com aproximadamente 32.000 palavras. A última edição, neste novo milênio, contará com aproximadamente 55.000.

17 "Não é dado a qualquer um mergulhar na multidão: tal desfrute é uma arte, e só faz, às expensas do gênero humano, esse 
lauto banquete de vitalidade quem, desde o berço, recebeu de uma fada o gosto do disfarce e da máscara, o ódio do domicílio e a paixão da viagem". Baudelaire, Charles, O spleen de Paris, pequenos poemas em prosa. Rio de Janeiro: Imago, 1995. (p.57).

${ }^{18}$ Benjamin, Walter. Charles Baudelaire - Um lírico no auge do capitalismo. Obras Completas III. São Paulo: Brasiliense, 1994.

${ }^{19}$ Walter Benjamin chamava a literatura fisiologista de "material para ser vendido em feiras", produto essencialmente pobre e invariavelmente "pequeno-burguês". "De fato, o mais indicado era dar às pessoas uma imagem amistosa das outras. Com isso, os fisiologistas teciam, a seu modo, a fantasmagoria da vida parisiense." Benjamin, Walter. Charles Baudelaire - Um lírico no auge do capitalismo. Obras Completas III. São Paulo: Brasiliense, 1994, (p.36).

20 "Duas ou três coisas que sei dela (Paris): Que não foi à toa que tenha sido em Paris que Baudelaire tenha reinventado, dado novo sentido, ao verbo 'flanar'. Em matéria de desfrute urbano, há pouca coisa mais agradável do que flanar em Paris." Conti, Mário Sergio. Duas ou três coisas que sei dela. 05/09/2003. Disponível em: http://nominimo.ibest.com.br/servlet/newstorm. notitia.apresentacao.ServletDeNoticia?codigoDaNoticia=7389\&dataDoJornal=atual. Para tanto, ver: Baudelaire, Charles, $O$ spleen de Paris, pequenos poemas em prosa. Rio de Janeiro: Imago, 1995. Certo que não foi à toa ter sido em Paris que Baudelaire tenha reinventado, dado um sentido diferente ao verbo "flanar". Mas em matéria de desfrute urbano, há pouquíssimas coisas ainda a serem flanadas pelas Américas, diferentemente do continente europeu. Elas são é zapeadas. Onde havia quarteirões, bares, cinemas, restaurantes e praças, agora há estacionamentos, shoppings e avenidas. E é claro, cybercafés, terminais de computadores e redes. Entre os que flanam e os que passam, zapeando, a imaterialidade parece destinada a eliminar os primeiros. Toda convivência pacífica entre temporalidades diferentes tem algo de ingênua, provisória. Esse zapping de que falamos é o grande tema da experimentação subjetiva contemporânea, onde os media absorvem inclusive as relações tradicionais.

21 "Uma sociedade de massas nada mais é do que aquele tipo de vida organizada que automaticamente se estabelece entre seres humanos que se relacionam ainda uns aos outros mas que perderam o mundo outrora comum a todos eles". Arendt, Hannah. Entre o Passado e o Futuro. São Paulo, Perspectiva, 2001, (p.126).

${ }^{22}$ Essa dimensão é mais facilmente captada no paradoxo central que a figura do flanador resume: trata-se precisamente de uma combinação peculiar de privado e público, qualidade essencialmente citadina que aparta a figura aqui discutida de qualquer convenção ou liturgia antiga; não é nem o herói clássico nem tampouco a figura do burguês tal como a entende (caricaturalmente) a tradição iluminista progressista. Sua presença se costura na exegese esteta de ver e devorar a cidade de maneira pessoal. Contrário à figura do burguês comumente entendido - cuja visibilidade funda o próprio tipo social e sua vida pública na cidade - trata-se de uma asserção diametralmente inversa: quão maior a invisibilidade deste indivíduo, maiores são as possibilidades de leituras sociais. Mary Gluck comenta: “A questão é ilustrada por meio de inúmeras histórias sobre a flânerie que distinguiam o verdadeiro flâneur do mero filisteu. Uma delas, por exemplo, compara o comportamento de um burguês comum com um flâneur diante da vitrine de uma loja que mostra uma peça de vestuário nova. Quando o burguês passa pela vitrine, ele casualmente olha para peça e pensa que sua mulher talvez gostasse dela, mas rapidamente vai embora. O flâneur, por outro lado, observa em silêncio a mesma peça na vitrine por horas, tecendo complexas reflexões sobre as tendências da moda indicadas pela roupa, os processos de fabricação implicados na feitura da peça e as origens recônditas da matéria-prima utilizada. O que era uma mercadoria independente e isolada para um observador comum, a imaginação do flâneur transforma em uma história coerente de aventuras exóticas e criações heróicas. Ela deu origem a 'centenas de diferentes reflexões que o outro observador nem sequer suspeita, ela ofereceu ao flâneur uma viagem em um mundo imaginário, um mundo brilhante, o melhor deles e, sobretudo, o mais mágico dos mundos'. Diferentemente do observador comum, pode-se dizer, o flâneur teve acesso 'a relações desconhecidas, a pensamentos não concebidos, a todo um novo mundo de idéias, reflexões e sentimentos, que emanam subitamente, como se saíssem da sonda de um geólogo’. O relacionamento único entre o flâneur e o ambiente urbano foi invariavelmente caracterizado pela metáfora da cidade como um texto, e do flâneur como um leitor". No original: "This point was illustrated though numerous anecdotes about flânerie that served to distinguish the true flâneur from the mere Philistine. One, for instance, recounted the contrasting behavior of an ordinary bourgeois and a flâneur in front of a shop window displaying a new piece of cloth. When the bourgeois passes the window, he briefly and casually surveys it with the thought that perhaps his wife might like it and then passes on. By contrast the flâneur remains transfixed before the same object for hours, engaged in complex reflections about the fashion trends indicated by the cloth, about the factory process that went into its making, about the far-off places where the raw materials originated. What had appeared as an isolated, and self-contained, commodity to the common observer, was transformed by the flâneur's imagination into a coherent story of exotic adventure and heroic creation. It had given rise 'to a hundred types of reflections which the other spectator did not even suspected; it gave him the opportunity for a long voyage in the imaginary world, that brilliant word, the best and above all, the fairest of all possible word'. Unlike the common observer, one of them argued, the flâneur had access 'to unknown connections, to unperceived insights, to an entirely new world of ideas, reflections and sentiments, which suddenly gush forth under the probe of geologist'. The unique relationship between the flâneur and the urban environment was invariably characterized by the metaphor of the city as text and the flâneur as reader." Gluck, Mary. The Flâneur and the Aesthetic Appropriation of Urban Culture in Mid-19 ${ }^{\text {th }}$-century Paris. Theory, Culture \& Society. Explorations in Critical Social Science. vol $^{\circ} 20, \mathrm{n}^{\circ}$ 5, 2003. (p.70).

${ }^{23}$ Simmel, Georg. A metrópole e a vida mental. IN: Velho, Otavio (org). O Fenômeno Urbano. Rio de Janeiro: Jorge Zahar, 1967. (p.14).

${ }^{24}$ Como explica Benjamin: "As pessoas tinham de se acomodar a uma circunstância nova e bastante estranha, característica da cidade grande. Simmel fixou essa questão acertadamente: 'Antes do desenvolvimento dos ônibus, dos trens, dos bondes no século XIX, as pessoas não conheciam a situação de terem de se olhar reciprocamente por minutos, ou mesmo por horas a fio, 
sem dirigir a palavra umas às outras'." Benjamin, Walter. Charles Baudelaire - Um lírico no auge do capitalismo. Obras Completas III. São Paulo: Brasiliense, 1994, (p.36).

25 “A metrópole extrai do homem, enquanto criatura que procede a discriminações, uma quantidade de consciência diferente da que a vida rural extrai. Nesta, o ritmo da vida e do conjunto sensorial de imagens flui mais lentamente, de modo mais habitual e mais uniforme. É precisamente nesta conexão que o caráter sofisticado da vida psíquica metropolitana se torna compreensível - enquanto oposição à vida de pequena cidade, que descansa mais sobre relacionamentos profundamente sentidos e emocionais". Idem.

${ }^{26}$ Ibidem, (p.15).

${ }^{27}$ Não se trata de uma suposta formação inata ao habitante da grande cidade, pois o próprio Simmel indica que as mentes mais conservadoras, à força dos transtornos inevitáveis que tal modo de vida impõe, acabam por se acomodar a este ritmo de acontecimentos. Em todas as milhares de variações individuais que a grande cidade dispõe, o que ocorre é o uso do intelecto e não do coração, dos sentimentos - para se guiar em meio ao poder avassalador da vida metropolitana, diversificando-se e se ramificando em muitas direções, de maneira a integrar-se com os discretos fenômenos da cidade. Trata-se de uma transformação em que a conscientização cresce em importância e assume as prerrogativas psíquicas, com o objetivo de defender o indivíduo das correntes e discrepâncias externas em muito ameaçadoras ao seu ambiente e que, de outra forma, o desenraizariam ininterruptamente.

${ }^{28}$ A diferença é fundamental: trata-se de transferir todas as relações emocionais e íntimas entre pessoas para princípios racionais. O homem vira um número e é tomado como um elemento que é em si mesmo indiferente: a individualidade é reduzida à questão: 'quanto?', e apenas as realizações objetivas e mensuráveis são de interesse. São estes aspectos que contrastam com a natureza do pequeno círculo, em que essa vida psíquica (ou subjetividade) moderna é estranha e onde, de maneira inversa, o fato de se conhecer o distribuidor e o cliente são fatores fundamentais. A metrópole moderna, escreve Simmel, "é provida quase que inteiramente para compradores inteiramente desconhecidos, que nunca entram pessoalmente no campo de visão propriamente dito do produtor". Simmel, Georg. A metrópole e a vida mental. IN: Velho, Otavio (org). O Fenômeno Urbano. Rio de Janeiro: Jorge Zahar, 1967, (p.16).

${ }^{29}$ A matriz fisiológica do blasé não se desvincula da economia monetária, da operação de reduzir tudo a números. O blasé, nesse sentido, consiste na deterioração do poder de discriminar e de valorar algum objeto de maneira diferencial. Claro que os objetos são percebidos, mas seu significado e valores são experimentados (ou vivenciados, nos termos de Benjamin) como destituídos de substância. Os objetos passam a gravitar em prateleiras infinitas de um lusco-fusco uniformizado, onde nenhum objeto guarda preferência substantiva sobre outro: trata-se do mais puro reflexo da economia monetária, agora interiorizada, onde o dinheiro nivela todas as coisas ao mesmo denominador comum: objetos. Mas não se trata de um processo unidirecional, pois é a própria autopreservação subjetiva, reagindo à proliferação desmesurada de objetos, que causa a desvalorização de todo o mundo objetivo: a personalidade embotada do indivíduo metropolitano é um mecanismo de defesa, uma recusa a reagir a estímulos infinitos e a procura de uma possibilidade de acomodação. Como fica claro, Simmel entende o blasé de forma positivada, como característica “que as pessoas estúpidas não tem”. Ibidem, (p.18).

${ }^{30}$ São tipos próximos em sua relação com a cidade, mas opostos na sua relação com o espaço. Decerto ambos indicam a chegada da modernidade, mas enquanto o blasé de Simmel já incorpora todo o alheamento espacial típico da pósmodernidade, o flâneur marca a presença de uma força moderna mas também antimodernizante. Seu andar vagaroso, virtualmente acompanhado de uma tartaruga, traduz sua ojeriza às velocidades e seu conservadorismo para com as formas e forças modernas. Ao contrário de zapeador e do blasé de Simmel, que são tomados e expurgados dos lugares, o flâneur se autogoverna. Em oposição à imersão absoluta do zapeador, o flanador é um indivíduo marcado pelo heterogoverno.

31 "A atividade criativa do popular flâneur ainda estava atrelada a uma modernidade empiricamente definível, cuja existência, presumia-se, era independente do artista. Em contraposição, a modernidade vanguardista do flâneur não existia enquanto realidade objetiva ou potência inerente à natureza da realidade. Ela só ganha existência depois que o mundo empírico das aparências é radicalmente desmantelado, desmontado em seus muitos componentes e então novamente montado como obra de arte. A modernidade deixa de ser um texto social, que esperara por anos para ser decifrada por um escritor urbano; ela se torna um texto estético que precisa ser recém-criado por meio da ação imaginativa do artista". No original: "The creative activity of the popular flâneur was still linked to an empirically definable modernity that was presumed to exist independently of the artist. By contrast, the avant-garde flâneur's modernity no longer existed as an objective reality or potentiality inherent in the nature of reality. It came into existence only after the empirical world of appearances had been radically dismantled, broken into its component parts, and newly reassembled as a work of art. Modernity had ceased to be a social text, which waited to be deciphered by the urban writer; it had become an aesthetic text, which needed to be freshly created thought the artist's imaginative act." Gluck, Mary. The Flâneur and the Aesthetic Appropriation of Urban Culture in Mid-19 ${ }^{\text {th }}$-century Paris. Theory, Culture \& Society. Explorations in Critical Social Science. vol ${ }^{\circ}$ 20, $n^{\circ}$ 5, 2003, (p.77).

32 "São tendências que a atualidade exemplifica fartamente, e que nada mais têm a ver com o ideal da perfeição individual ou societária. Enquanto os jovens dos anos 60 e 70 contestavam o poder dos mais velhos para tomar seu lugar, os jovens bárbaros de nossas cidades não votam, não se inscrevem nas listas eleitorais. Eles opõem às injunções adultas a passividade dos fumantes, despertando apenas por alguns instantes em brincadeiras violentas com a polícia. O bem deixou de ser a meta única. Já não passa de um elemento entre muitos outros. A parte do diabo tem aí o seu lugar.”. Maffesoli, Michel. A parte do Diabo resumo da subversão pós-moderna. Rio de Janeiro: Record, 2004, (p.52-53).

${ }^{33}$ Essa sociedade Frankenstein, tal como anotou Ciro Marcondes Filho, "é marcada pelo investimento no superficial, na crença no imprevisível, no indeterminado. Instala-se a perda das referências filosóficas clássicas - datada da modernidade - na filosofia, na arte, na política, na história, nas ciências humanas, ficando em seu lugar uma precedência da técnica, um uso instrumental da ciência, o domínio amplo e genericamente abrangente dos meios de comunicação, que passam a recontar e a reordenar a história, a política e a cultura. Como já mencionado, o sujeito se fractaliza e o comportamento é cínico, 
indiferente, autocentrado." Ciro Marcondes Filho - A Sociedade Frankenstein. São Paulo, Ed. do Autor, 1991. Disponível em: http://www.eca.usp.br/nucleos/filocom/frank.doc

${ }^{34}$ Há nisso tudo um preocupante perecimento do conhecimento, executado por uma estranha e chocante dificuldade em separar informação solta (boato) de conhecimento (história). A esse respeito, Roger Chartier foi esclarecedor. "Se alguém busca informações sobre o Holocausto no mundo da cultura impressa ou se, ao fazer um trabalho para a escola, consulta enciclopédias, livros de história, revistas reconhecidas, não terá tanto contato com a propaganda dos negacionistas, que é totalmente marginalizada. Em muitos países ela está proibida ou só existe em revistas que não se encontram facilmente. Assim, as informações sobre o Holocausto serão obtidas em textos mais ou menos controlados. Um jornalista fez a mesma investigação sobre o Holocausto na internet e encontrou uma enorme quantidade da propaganda negacionista, revisionista, apresentada com todas a aparência de texto científico. Se o leitor não está preparado para estabelecer a diferença que já foi estabelecida na cultura impressa por meio do formato editorial ou das comunidades cientificas, há um risco de confusão entre o que é informação e o que é saber. É informação conhecer toda essa propaganda revisionista, mas não é saber. É o contrário do saber, é a falsificação da verdade". Chartier, Roger. Conversa com Roger Chartier - por Isabel Lustosa. Revista Trópico. Disponível em http://pphp.uol.com.br/tropico/html/textos/2479,1.shl

${ }^{35}$ Baudrillard, Jean. Tela total/mito: Ironias da era do virtual e da imagem. Porto Alegre: Sulina, 1997.

${ }^{36}$ Mas não se trata de falta de iluminismo, mas de excesso. Deve-se procurar as raízes desse energúmeno digital na falência de um projeto educacional ensimesmado, anacronicamente iluminista. A suposição de que ao se educar o outro, este outro educa os demais, como em um previsível efeito em cadeia, falha ao se deparar com uma cognição que só faz recortar velozmente, em espirais concêntricas. A falência dos pólos decisórios de poder e autoridade implica, sem rodeios, em agentes incapazes de reconhecer uma verdade ou um consenso sobre determinado assunto. O idiota contemporâneo é, assim, incapaz não apenas de reconhecer o consenso da comunidade científica sobre um determinado assunto, mas mesmo de entendê-lo ou perceber seu funcionamento.

37 “O idiota aparecerá numa outra época, num outro contexto. O antigo idiota queria evidências, às quais ele chegaria por si mesmo: nessa perspectiva, duvidaria de tudo, mesmo de $3+2=5$; colocaria em dúvida todas as verdades da Natureza. O novo idiota não quer, de maneira alguma, evidências, não se 'resignará' jamais a que $3+2=5$, ele quer o absurdo - não é a mesma imagem do pensamento. $\mathrm{O}$ antigo idiota queria o verdadeiro, mas o novo quer fazer do absurdo a mais alta potência do pensamento, isto é, criar. O antigo idiota queria não prestar contas senão à razão, mas o novo idiota, mais próximo de Jó que de Sócrates, quer que se lhe preste contas de 'cada vítima da história', esses não são os mesmos conceitos. Ele não aceitará jamais as verdades da História. O antigo idiota queria dar-se conta, por si mesmo, do que era compreensível ou não, razoável ou não, perdido ou salvo, mas o novo idiota quer que lhe devolvam o perdido, o incompreensível, o absurdo. Seguramente não é o mesmo personagem, houve uma mutação. E, todavia, um fio tênue une os dois idiotas, como se fosse necessário que o primeiro perdesse a razão para que o segundo reencontrasse o que o outro tinha perdido a princípio, ganhando-a". Deleuze, Gilles \& Guattari, Félix. O que é a Filosofia? Rio de Janeiro: Ed. 34, 1997, (p.85).

38 “Além disso, informa o que devemos entender propriamente por tais massas. Não se pode pensar em nenhuma classe, em nenhuma forma de coletivo estruturado. Não se trata de outra coisa senão de uma multidão amorfa de passantes, de simples pessoas nas ruas." E continua assim, na nota de rodapé: "Emprestar uma alma a esta multidão é o desejo mais íntimo do flâneur. Os encontros com ela são para ele a vivência que nunca se cansa de narrar.” Benjamin, Walter. Charles Baudelaire Um lírico no auge do capitalismo. Obras Completas III. São Paulo: Brasiliense, 1994, (p.113).

${ }^{39}$ Lan house significa, literalmente, 'casa de LAN (Local Area Network)': um estabelecimento comercial para se conectar em rede, jogando videogame ou se conectando a outras redes como, é claro, a Internet.

${ }^{40} \mathrm{O}$ que os computadores pessoais fazem à sensibilidade individual não é muito diferente daquilo que se iniciou com a fabricação e venda em larga escala do automóvel, um espaço fechado de vivência solitária. Passando por óculos escuros de todos os tipos, headphones e walkmans de toda sorte, há todo um complexo industrial a fabricar ferramentas criadoras de universos pessoais, ambientes que se fecham a uma única possibilidade de representação do ambiente. A coerência desse tempo é a de uma desterritorialização bruta, conquanto individual: "O ser humano contemporâneo é fundamentalmente desterritorializado. Com isso quero dizer que seus territórios etológicos originários - corpo, clã, aldeia, culto, corporação não estão mais dispostos em um ponto preciso da terra, mas se incrustam, no essencial, em universos incorporais. A subjetividade entrou no reino de um nomadismo generalizado. Os jovens que perambulam nos boulevards, com um walkman colado no ouvido, estão ligados a ritornelos que foram produzidos longe de suas terras natais". Guattari, Félix. Caosmose: Um novo paradigma estético. São Paulo: 34, 1992, (p.169).

${ }^{41}$ Pereira, Beltrina Purificação da Côrte. São Paulo: Cidade misturada/cidade inconclusa zapeando a metrópole metalizada. Tese de Doutorado, ECA-USP, 1997. Ver também: De Gournay, Chantal et alii. Dessier le coq et l'ane: du zapping comme symptome d'une nouvelle culture televisuelle. Paris: 1988.

42 "Michael Joyce também nos fala dessa noção de contorno, desse 'todo' oscilante, múltiplo e transitório, que se forma com nossa imersão no ambiente hipermidiático. O viajante intui que exista uma ordem, uma coerência. A natureza do desafio é ambígua: embora exista uma prazer no perder-se, existe outro muito grande no reencontrar-se. Em um primeiro momento, a ordem é anulada; no segundo, ela é reconstruída. Quando o viajante anula a ordem, na verdade, ele nega a globalidade, exatamente por não conhecê-la, por não dispor de um olhar panorâmico. Para reconstituir a ordem global, o nômade precisa contar com as inferências que obtém localmente." Lucia Leão. O labirinto da hipermídia - Arquitetura e navegação no ciberespaço. São Paulo: Iluminuras, 2001.

${ }^{43}$ A leitura de um diálogo de chat transcrito é em larga medida inútil, pois não é apenas o contexto que lhe falta, ou seja, as linhas que lhe precederam e que lhe sucederam, mas todo o universo virtual que lhe dá sustentação. Em outras palavras, uma transcrição de bate-papo não pode traduzir o sentido que por ali escorreu, pois este se encontra amputado da fantasia que lhe deu origem. A este respeito, ver o capítulo Fantasia: um bate-papo comigo mesmo (ou com ninguém). 
44 “Neste caso, ‘comunicar' é o modo privilegiado das sociedades de 'política fragmentada'. (...) Para assegurar sua coesão, as sociedades dotadas de memória valem-se da história; as sociedades sem memória da comunicação." Sfez, Lucien. Crítica da comunicação. São Paulo: Loyola, 2000, (p.25).

45 “Ao contrário, esse ego está subvertido e disperso pelo espaço social. Isso transforma a noção de sujeito como dotado de um eu estável, levando-a bem perto da noção de sujeito freudiano, o sujeito descentrado do inconsciente. Assim, a descorporificação, que é experimentada nos deslocamentos da imersão e das sucessivas incorporações, não deve ser considerada uma descarnalização, um estado fixo, como querem alguns, mas muito mais como a colocação em cena do movimento mesmo do desejo". Santaella, Lucia. Culturas e artes do pós-humano - da cultura das mídias à cibercultura. São Paulo: Paulus, 2003, (p.215). A esse respeito, conferir os capítulos Édipo e Maquinismo Esquizo e Fantasia: um bate-papo comigo mesmo (ou com ninguém), presentes neste trabalho.

${ }^{46}$ Calvino, Italo. As cidades invisíveis. São Paulo: Folha de São Paulo, 2003, (pág. 55-56).

47 "Quando os amantes com os corpos nus rolam pele contra pele à procura da posição mais prazerosa ou quando os assassinos enfiam a faca nas veias escuras do pescoço e quando mais a lâmina desliza entre os tendões mais o sangue escorre, o que importa não é tanto o acasalamento ou o degolamento mas o acasalamento de suas imagens límpidas e frias no espelho.” Idem. ${ }^{48}$ Ibidem.

${ }^{49}$ Ibidem. De maneira categórica, ao falar das cidades delgadas às páginas 38 e 39, Calvino diz que não há sentido em separar as cidades entre "felizes" e "infelizes", "boas" ou "más". Haveria apenas as cidades que permanecem fluindo, crescendo em vida, aquelas que continuam ao longo dos anos a das mutações a dar forma aos desejos e aquelas em que os desejos conseguem cancelar a cidade ou são por esta cancelados. Desnecessário dizer que tipo de cidade é Valdrada. Esperamos apenas que a mesma sorte da cidade especular não seja a do indivíduo especular.

50 "Holtzman encontra no surgimento da MTV, em 1981, um exemplo radical da sintaxe que é própria do vídeo e que está na habilidade desse meio para apresentar simultaneamente diversas histórias diferentes justapostas por cortes curtos produzidos pela edição eletrônica. Para o autor, a MTV desafiou nossa capacidade sensória com imagens vívidas, cortes rápidos e sons eletrônicos intensos, preparando nossa sensibilidade para o mundo digital em devir. Antes da MTV, pensava-se que ninguém seria capaz de fazer sentido de um corte menor do que dois segundos. Hoje, os vídeos usam regularmente cortes de um terço ou um quarto de segundo". E continua: "Atualmente, continua Holtzman, a não linearidade permeia todas as partes de nossa cultura. E na medida em que as novas mídias descontínuas penetram em nossa vida, elas mudam não apenas nossos modos de pensar, mas também nossa percepção da realidade. Minha hipótese vai mais longe do que a de Holtzman. A descontinuidade das mídias não muda apenas nossa forma de pensar. Essa descontinuidade é perfeitamente homóloga aos modos contemporâneos de viver. Basta imaginar como se processa o cotidiano de uma pessoa em uma grande cidade, acompanhada de um celular conectado na internet, de um notepad, ou mesmo de um notebook, movendo-se no trânsito caótico, atendendo a compromissos disparatados". Santaella, Lucia. Culturas e artes do pós-humano - da cultura das mídias à cibercultura. São Paulo: Paulus, 2003, (p.96-97).

51 "Não há um eu no centro, como também não há pessoas repartidas sobre a circunferência. Nada além de uma série de singularidades na rede disjuntiva, ou estados intensivos no tecido conjuntivo, e um sujeito transposicional sobre todo o círculo, passando por todos os estados, triunfando de uns como de seus inimigos, saboreando os outros como seus aliados, recolhendo em toda parte o prêmio fraudulento de seus avatares." Deleuze, Gilles \& Guattari, Félix. O Anti-Édipo. Capitalismo e Esquizofrenia. Rio de Janeiro: Imago, 1976, (p.118).

52 Arendt, Hannah. Entre o Passado e o Futuro. São Paulo, Perspectiva, 2001, (p.31).

53 "Ich lebe mein Leben in wachsenden Ringen", ou "Eu vivo minha vida em círculos crescentes", como de certa feita traduziu José Reis. O poema original "Ich lebe mein Leben in wachsenden Ringen" é o que segue: "Ich lebe mein Leben in wachsenden Ringen, / die sich über die Dinge ziehn. / Ich werde den letzten vielleicht nicht vollbringen, / aber versuchen will ich ihn. / Ich kreise um Gott, um den uralten Turm, / und ich kreise jahrtausendelang; / und ich weiß noch nicht: bin ich ein Falke, ein Sturm / oder ein großer Gesang." Rainer Maria Rilke, 20/09/1899, Berlin-Schmargendorf. Este poema pertence à primeira parte da obra "Das Buch vom Mönchischen Leben”, publicado originalmente em 1899. Disponível em: http://rainermaria-rilke.de/05a002lebensringe.html

${ }^{54}$ Hannah Arendt parece ter uma visão pouco otimista a respeito das possibilidades desse peregrino encontrar seu eixo: "É tentador acrescentar, porém, que isso 'é assim apenas teoricamente'. O que muito mais provavelmente pode vir a acontecer - e que Kafka descreveu amiúde em outras estórias e parábolas - é que 'ele', incapaz de encontrar a diagonal que o levaria para fora da linha de combate, para o espaço constituído idealmente pelo paralelogramo de forças, 'morra de exaustão', deperecido sob a pressão do constante embate, esquecido de suas primitivas intenções e apenas cônscio da existência dessa lacuna no tempo que, enquanto ele viver, será o território sobre o qual terá que se manter, muito embora não se assemelhe a um lar, e sim a um campo de batalha.” Arendt, Hannah. Entre o Passado e o Futuro. São Paulo, Perspectiva, 2001, (p.39).

${ }^{55}$ Idem, p.40.

${ }^{56}$ A diferença entre acreditar que se muda o mundo ou acreditar que, antes, é o mundo que muda você tem bibliografia farta no debate das ciências cognitivas: "Herman Witkin introduziu uma dicotomia influente, definindo dois estilos cognitivos básicos: independente do campo de ação e dependente do campo de ação. O primeiro implica barreiras mais fortes entre o eu e o não-eu, e uma maior tendência para confiar em referências internas. Outra dicotomia que também está relacionada é o conceito de locus de controlo de J. B. Rotter. Os indivíduos possuem locus de controlo interno quando têm tendência a acreditar que fazem acontecer as coisas; possuem locus de controlo externo quando têm tendência a ver as coisas como 'acontecendo-lhes'. O locus de controlo interno está mais próximo do 'rígido' que do 'flexível', tanto conceitual como empiricamente. Outras dicotomias que avultam para um estudo correlativo mais aprofundado incluem convergente ou divergente, verbal ou espacial e cérebro esquerdo ou cérebro direito". Turkle, Sherry. O Segundo Eu - Os computadores e o espírito humano. Lisboa: Presença, 1989. (p.93; nota bibliográfica 7 e 8). 


\section{BIBLIOGRAFIA}

ALPHEN, Fernand. A Internet não é nada. Digestivo Cultural, 24/10/2003. Disponível em: http://www.digestivocultural.com/colunistas/coluna.asp?codigo $=1211$

ANDERS, Günther. O antiqüismo do ser humano. A alma na era da segunda revolução industrial. Tradução de Ciro Marcondes Filho. Disponível em: www.eca.usp.br/nucleos/filocom/traducoes.html

ANTOUN, Henrique. O poder da comunicação e o jogo das parcerias na cibercultura. In: COMPÓS $13^{\circ}$ Encontro Anual da Associação Nacional dos Programas de Pós-Graduação em Comunicação, São Bernardo do Campo, 2004.

ARENDT, Hannah. Entre o passado e o futuro. São Paulo: Perspectiva, 2001.

ARONOWITZ, Stanley, BARBARA Martinsons, and MICHEL Menser. Technoscience and Cyberculture. New York: Routledge, 1996.

ASSIS, Jesus Paula. No.: Multimídia é coisa para Titãs. 02/2001. Disponível em http://www.no.com.br

ASSMANN, Selvino J. Macchine, astuzia, passione: per la genesi della società civile in Hegel. IN: LUGARINI, L., RIEDEL, M e BODEI, R. Filosofia e società in Hegel (a cura di Franco Chiereghin). Trento: Quaderni di Verifiche 2, 1977. (p.61-89).

AUMONT, Jacques. A Imagem. Campinas: Papirus, 2000.

BAIRON, Sérgio. Multimídia. São Paulo: Global, 1995.

BAIRON, Sérgio \& PETRY, Luís Carlos. Hipermídia: Psicanálise e História da Cultura. São Paulo: EDUCS/ Mackenzie, 2000.

BARNET, Belinda. Technical Machines and Evolution. CTheory Magazine - Theory, Technology and Culture. Vol. 27, No 1-2. Editores: Arthur and Marilouise Kroker. Article 139, 04/03/2004. Disponível em: http://www.ctheory.net

BARTHES, Roland. Crítica e Verdade. São Paulo: Perspectiva, 1970. O óbvio e o Obtuso. Rio de Janeiro: Nova Fronteira, 1990.

BASTOS, Marco Toledo. O Sujeito e os Chats. Revista 404nOtF0und: Ano 2, vol. 1, n 13, ISSN 16762916, Fevereiro 2002.

BAUDELAIRE, Charles, O spleen de Paris, pequenos poemas em prosa. Rio de Janeiro: Imago, 1995.

BAUDRILLARD, Jean. O Sistema dos Objetos. São Paulo: Perspectiva, 1973.

Da Sedução. Campinas: Papirus, 1992.

Para uma crítica da economia política do signo. Lisboa: Elfos, 1994.

As estratégias fatais. Rio de Janeiro: Rocco, 1996. 
Tela total/mito: Ironias da era do virtual e da imagem. Porto Alegre: Sulina, 1997.

A Internet ruma para seu fim. Jornal Folha de São Paulo, Ilustrada, 19/02/1998.

O elogio radical da parte maldita. Entrevista realizada por Juremir Machado da Silva.

Jornal Folha de S. Paulo, Ilustrada, 25/11/1998. Versão integral http://www.pucrs.br/famecos/10-4.html

A Transparência do Mal: ensaio sobre os fenômenos extremos. Campinas: Papirus,

2003.

The Violence of the Global. CTheory - Theory, Technology and Culture. Vol. 26, No 12, artigo 129, 20/05/2003. Traduzido para o inglês por Francois Debrix. Disponível em:

http://www.ctheory.net/text_file.asp?pick=385 e também disponível em espanhol, La Violencia de lo

Global, na tradução de Carlos Silva em http://www.ctheory.net/text_file.asp?pick=386\#_edn1

BAUMAN, Zygmunt. O mal-estar da Pós-Modernidade. Rio de Janeiro: Jorge Zahar, 1998.

Modernidade Líquida. Rio de Janeiro: Jorge Zahar, 2001.

A Sociedade Líquida. Entrevista cedida ao Jornal Folha de São Paulo, Caderno Mais!, Domingo, 19/10/2003, p.6.

As novas guerras do prazer. Entrevista concedida a Gerry McCarthy. Jornal Folha de

S. Paulo, Caderno Mais!, Domingo, 27/06/2004, p.3.

Amor Líquido - Sobre a Fragilidade das Relações Humanas. Rio de Janeiro: Jorge

Zahar, 2004.

BEASLEY-MURRAY, Jon. Deleuze, Guattari and the Human Security System. Literature Program, Duke University. Disponível em: http://lists.village.virginia.edu/ spoons/marxism/jbm.fascism.html

BECK, Ulrich. ¿Qué es la globalización? Barcelona: Paidós, 1998.

BENEDIKT, M., Cyberspace: Some Proposals. In: BENEDIKT, M (ed.) Cyberspace: First Steps. Cambridge: MIT Press, 1991.

BENJAMIN, Walter. Obras Escolhidas I, II e III. São Paulo, Brasiliense, 1994.

Teoria do Conhecimento, Teoria do Progresso. In: Theoretics of Knowledge; Theory of Progress. IN: The Philosophical Forum. Vol. XV, 1-2, 1983-84, p.1-40. Tradução de Carlos Eduardo Jordão Machado.

BENVENISTE, E. Problemas de Lingüística Geral. Campinas: Pontes, 1989.

BEN-ZE'EV, Aaron. Love Online - Emotions on the Internet. Cambridge: University Press, 2004.

BERGSON, Henri. A Evolução Criadora. Rio de Janeiro: Delta, 1964.

Les deux sources de la morale et de la religion. Paris: PUF, 1997.

BERMAN, Marshall. Tudo que é Sólido Desmancha no Ar: A Aventura da Modernidade. $16^{\circ}$ reimpressão, São Paulo: Cia das Letras, 1999. 
BERMUDES, Sérgio. A mecânica do mal-entendido. Revista eletrônica No Mínimo, 05/2004. Disponível em: http://nominimo.ibest.com.br

BEY, Hakim. T.A.Z. The Temporary Autonomous Zone: Ontological Anarchy, Poetic Terrorism. New York: Autonomedia, 1991; T.A.Z.: Zona Autônoma Temporária. São Paulo: Conrad, 2001. Também disponível em: http://www.hermetic.com/bey/taz3.html

BIRMAN, Joel. Cartografias do Feminino. São Paulo: Ed. 34, 1999.

Estilo e Modernidade em Psicanálise. São Paulo: Ed. 34, 1997.

BORGES, Jorge Luis. Obras Completas. Rio de Janeiro: Globo, 2000.

História Universal da Infâmia. Porto Alegre: Globo, 1978.

BORGES, Julio Daio. Retrato do jovem quando artista no século XXI. Revista Nova-e. Disponível em: http://www.digestivocultural.com/colunistas/coluna.asp?codigo $=665$

BRENNAN, Teresa \& JAY, Martin, (eds.). Vision in context. Historical and contemporary perspectives on sight. London: Routledes, 1996.

BUKATMAN, Scott. Terminal Identity. The virtual subject in postmodern science-fiction. Durhan: Duke University Press, 1993.

CALVINO, Italo. As cidades invisíveis. São Paulo: Folha de São Paulo, 2003.

CANCLINI, Nestor García. Culturas híbridas. São Paulo: Edusp, 1997.

CASTELLO, José. Sem respostas nem soluções. Revista eletrônica No Mínimo. 10/06/2003. Disponível em: http://nominimo.ibest.com.br/servlet/newstorm.notitia.apresentacao.ServletDeNoticia?codigoDa $\underline{\text { Noticia }=5899 \& \text { dataDoJornal }=\text { atual }}$

CASTELLS, Manuel. A Galáxia da Internet. Rio de Janeiro: Jorge Zahar, 2003.

CHENAUlT, Brittney G. Developing Personal and Emotional Relationships Via Computer-Mediated Communication. CMC Magazine: http://www.december.com/cmc/mag/1998/may/chenault.html

CLARKE, Arthur C. 3001 - The Final Odyssey. New York: Ballantine Books, 1998.

COELHO NETTO, José Teixeira. A Cultura Fractal é Fatal? Revista Comunicação\&Política (São Paulo), Ed. Oito de Março, v. 9, n. 2, 3 e 4, 1989.

Dicionário Crítico de Política Cultural. São Paulo: Iluminuras, 2004.

CONNOR, Steven. Cultura Pós-Moderna: Introdução as teorias do contemporâneo. São Paulo: Loyola, 2000 .

CONTI, Mário Sergio. Duas ou três coisas que sei dela. 05/09/2003. Disponível em:

http://nominimo.ibest.com.br/servlet/newstorm.notitia.apresentacao.ServletDeNoticia?codigoDaNoticia= 7389\&dataDoJornal=atual

COYNE, Richard. Technoromaticism: digital narrative, holism, and the romance of the real. Cambridge: MIT Press, 1999. 
CRYSTAL, David. Language and the Internet. Cambridge: University Press, 2001.

DEBORD, Guy. A sociedade do espetáculo. Rio de Janeiro: Contraponto, 1997.

DELEUZE, Gilles. Proust e os Signos. Rio de Janeiro: Globo, 1981.

Conversações. Rio de Janeiro: Ed. 34, 1992.

O Bergsonismo. São Paulo, Ed. 34, 1995.

Lógica do Sentido. São Paulo: Perspectiva, 2003.

O que é a Filosofia? Rio de Janeiro: Ed. 34, 1997.

DELEUZE, Gilles \& PARNET, Claire. Dialogues. Paris: Flammarion, 1977; Diálogos. São Paulo: Escuta, 1998.

DELEUZE, Gilles \& GUATTARI, Félix. O Anti-Édipo. Rio de Janeiro: Imago, 1976.

Mil platôs. Rio de Janeiro: Ed. 34, 1997. Cinco vols.

DeMAUSE, Lloyd. Foundations of Psychohistory. New York: Creative Roots Pub, January 1982.

DERRIDA, Jacques. A escritura e a diferença. São Paulo: Perspectiva, 1971.

A Farmácia de Platão. São Paulo: Iluminuras, 1997.

DOMINGUES, Diana (org.) A arte no século XXI - A humanização das tecnologias. São Paulo: Unesp, 1997.

DUFFY, Clifford. Body without Organs Miller Ma'am. Deleuze-Guattari spoon list. 25/10/2003.

DYSON, Esther. Release 2.0: A design for living in a digital age. New York: Broadway Books, 1997.

ECO, Umberto. A Estrutura Ausente: Introdução à Pesquisa Semiológica. São Paulo: Perspectiva, 1971. Muito além da Internet. Jornal Folha de São Paulo, Caderno Mais!, 14/122003.

Interpretação e Superinterpretação. São Paulo: Martins Fontes, 1997.

EDWARDS, Elwyn. Information Transmission. London: Chapman \& Hall, 1964.

ESS, Charles (org.), Philosophical perspectives on computer-mediated communication. New York: State University of New York Press, 1996.

FAULKNER, William. O Som e a Fúria. São Paulo: Cosac \& Naify, 2004.

FAWCETT, Fausto. Santa Clara Poltergeist. Rio de Janeiro: Eco, 1990.

FERNANDES, Millôr. Livro vermelho dos pensamentos de Millôr. Rio de Janeiro, Nórdica, 1973. 
FEYERABEND, Paul. Contra o Método. Esboço de uma teoria anárquica da teoria do conhecimento. Rio de Janeiro: Francisco Alves, 1989.

FISHER, Lawrence. The Geographic Interface Puts the World on the Desktop. New York Times, 05/021995. (F9).

FLUSSER, Vilém. Filosofia da caixa preta. São Paulo, Hucitec, 1985.

FREITAS, Jeanne Marie Machado de. Comunicação e psicanálise. São Paulo: Pulsional, 1994.

FREUD, Sigmund. Obras Completas. Rio de Janeiro: Imago, 1983.

FRIDMAN, Luis Carlos. Pós-modernidade: Sociedade da imagem e sociedade do conhecimento. História, Ciência e Saúde (Rio de Janeiro), v.6, n.2, 1999.

GIANNOTTI, José A. A instituição no passivo. Jornal Folha de São Paulo, Caderno Mais!. 09/01/2005.

GIBSON, Willian. Neuromancer. New York: Ace Book, 1995. São Paulo: Aleph, 2003. Também disponível em: http://gibson.hypermart.net/neuromancer.txt

GLEBER, Anke. The Art of Taking a Walk: Flânerie, Literature and Film in Weimar Culture. Princeton: Princeton University Press, 1999.

GLUCK, Mary. The Flâneur and the Aesthetic Appropriation of Urban Culture in Mid-19 ${ }^{\text {th }}$-century Paris. Theory, Culture \& Society: Explorations in Critical Social Science. vol ${ }^{\circ}$ 20, nº 5, 2003.

GOFFMAN, E. A Representação do Eu na Vida Cotidiana. Petrópolis: Vozes, 1996.

GOH, Irving. Dangerous Philosophy: Threat, Risk, and Security. CTheory Magazine - Theory, Technology and Culture. Vol. 27, No 1-2. Editores: Arthur and Marilouise Kroker. Article 143, 04/05/2004. Disponível em: http://www.ctheory.net

GUATTARI, Félix \& ROLNIK, Suely. Micropolítica: Cartografias do Desejo. Petrópolis: Vozes, 2000. GUATTARI, Félix. Revolução Molecular: Pulsações Políticas do Desejo. São Paulo: Brasiliense, 1985. Caosmose: Um novo paradigma estético. São Paulo: 34, 1992. Os 65 Sonhos. Jornal Folha de São Paulo, Caderno Mais!. 16/02/2003.

GUILLAUME, Marc. Téléspectres. IN: Traverses, n²6, out/1982, (p.18-28).

HABERMAS, Jürgen. Teoría de la acción comunicativa. Vol. I e II. Madrid: Taurus, 1987. Consciência moral e agir comunicativo. Rio de Janeiro: Tempo Brasileiro, 1989.

Tempo Brasileiro, 1990. Habermas, Jurgen. Pensamento Pós-Metafísico: estudo filosófico. Rio de Janeiro:

HALEY, Jay. A interação de esquizofrênicos. IN: BATESON, Gregory et alii. Schizophrenie und Familie. Frankfurt am Main: Suhrkamp, 1984. (pág.84-97). Do original: An Interactional Description of Schizophrenia. Psychiatry, vol.22 (1959), (pág.321-332). Tradução de Ciro Marcondes Filho. Disponível em: http://ww.eca.usp.br/nucleos/filocom/traducoes.html 
HALL, Stuart. A identidade cultural na pós-modernidade. Rio de janeiro: DP\&A, 2001.

HAMMAN, Robin B. The Role of Fantasy in the Construction of the On-line Other. Cybersociology Magazine. Diposnível em http://www.cybersociology.com/

Rhizome@Internet: Using the Internet as an example of Deleuze and Guattari's

'Rhizome'. 1996. Disponível em: http://www.socio.demon.co.uk/rhizome.html

HARAWAY, Donna. Donne, Tecnologie e Biopolitiche del Corpo. Milão: InterZone, 1995.

HARVEY, David. Condição Pós-Moderna, São Paulo: Loyola, 1996.

HEIDEGGER, Martin. Dir Frage nach der Technik. A questão da técnica. Tradução de Marco Aurélio Werle. Cadernos de tradução. Departamento de Filosofia da USP, N.2, 1997.

HELLER, Agnes. E FEHÉR, Ferenc. A Condição Política Pós-Moderna. Rio de Janeiro: Civilização Brasileira, 1998.

HERRING, Susan. Posting in a diferent voice: Gender and ethics in CMC. In: ESS, Charles (org.), Philosophical perspectives on computer-mediated communication. New York: State University of New York Press, 1996.

HILLS, Ken. Digital Sensations. Minneapolis: University of Minnesota Press, 1999.

HIRSCH, Morris. The chaos of dynamical systems. IN: Chaos, fractals and dynamics. FISCHER, P. \& SMITH, S.R. (eds.) New York: Marcel Dekker, 1985.

HÖLLDOBLER, Bert \& WILSOM, Edward O. The ants. Cambridge: Harvard University Press, 1990.

HONEYCUTT, Lee. Comparing E-Mail and Synchronous Conferencing in Online Peer Response. Written Communication, Vol. 18, No 1, 26-60. Sage Publications, 2001.

HOUAISS, Antônio. Dicionário Houaiss da Língua Portuguesa. São Paulo: Objetiva, 2001.

JAMESON, Fredric. Pós-Modernismo, A lógica cultural do capitalismo tardio, São Paulo: Ática, 1996.

JOHNSON, Steven. Interface Culture: How New Technology Transforms the Way We Create and Communicate. San Francisco: HarperEdge, 1997.

Emergence: The connected lives of ants, brains, cities, and software. Nova York: Scribner, 2001; Emergência: A dinâmica de rede em formigas, cérebros, cidades e softwares. Rio de Janeiro: Jorge Zahar, 2003.

JUPY Jr., Edmar de Araújo. Chats: comunicação e sociedade. Revista 404nOtF0und Ano 4, vol. 1, $\mathrm{n}^{\circ}$ 36, ISSN 1676-2916, 02/2004. Disponível em: http://www.facom.ufba.br/ciberpesquisa/404nOtF0und e também na Revista Ciberlegenda, Número 11, 2003. Disponível em http://www.uff.br/mestcii/jupy2.htm

KAFKA, Franz. Sonhos. São Paulo: Iluminuras, 2003.

KAMINSKI, Omar (org). Internet Legal: O Direito na Tecnologia da Informação. Londrina: Juruá Editora, 2003. 
KAMPER, Dietmar. Imanência dos media e corporeidade transcendental. Oito postos de observação para um futuro medial. Tradução de Ciro Marcondes Filho. Disponível em:

http://www.eca.usp.br/nucleos/filocom/traducao8.html

As máquinas são tão mortais quanto as pessoas. Uma tentativa de excluir o telemático

do pensamento. Tradução de Ciro Marcondes Filho. Disponível em:

http://www.eca.usp.br/nucleos/filocom/traducao9.html

KEHL, Maria Rita. Tensão Fraterna. Entrevista a Revista Insight. Revista Insight, Estruturas

Socioculturais, Ano XI, N 115. 03/2001, (páginas 4-9).

KEHL, Maria Rita (org) - Função Fraterna. Rio de Janeiro: Relume Dumará, 2000.

KELLNER, Douglas, 1995. Media Culture: Cultural studies, identity and politics between the modern and the postmodern. London/New York: Routledge, 1997.

KEMENY, John G. Homem e Computador. Rio de Janeiro, Cia Gráfica Lux, 1974.

KERCKHOVE, Derrick. A pele da cultura: uma investigação sobre a nova realidade eletrônica. Lisboa: Relógio D'Água, 1997.

KIRTCHEV, Christian As. A Cyberpunk Manifesto. The Cyberpunk Project, 14/02/1997.

KOLB, Anton. ESTERBAUER, Reinhold. RUCKENBAUER, Hans-Walter. Ciberética responsabilidade em um mundo interligado pela rede digital. São Paulo: Loyola, 2001.

KOYRÉ, A. Estudos de história do pensamento científico. Brasília: UNB, 1982.

KRISTEVA, Julia. História da Linguagem. Portugal: Edições 70, 1994.

KROKER, Arthur. The Possessed Individual. New York: St. Martin's, 1992.

KROKER, Arthur e KROKER, Marilouise. Hacking the Future: Stories for the flesh-eating 90's. New York: St. Martin's Press, 1995.

KUHN, Thomas. A estrutura das revoluções científicas. São Paulo: Perspectiva, 1976.

KUMAR, Krishan. Da Sociedade Pós-industrial à Pós-Moderna. Rio de Janeiro: Jorge Zahar, 1997.

KURZWEIL, Ray. Ser Humano Versão 2.0. Jornal Folha de S. Paulo, Caderno Mais!, 23/03/1993, p.4-9.

LACAN, Jacques. Os quatro conceitos fundamentais da Psicanálise. Rio de Janeiro: Jorge Zahar, 1990.

Seminário Livro 05. Rio de Janeiro: Jorge Zahar, 1999.

LEMINSKI, Paulo. O ex-estranho. São Paulo: Iluminuras, 2001.

LEMOS, André L. M. As Estruturas Antropológicas do Cyberespaço. Revista Textos de Cultura e Comunicação (Salvador). FACOM, UFBA. n. 35, 1996. Disponível em:

http://www.facom.ufba.br/ciberpesquisa/andrelemos

Ciber-socialidade: Tecnologia e Vida Social na Cultura Contemporânea. Salvador:

Cópia Reprográfica, 1998. Disponível em http://www.facom.ufba.br/ciberpesquisa/andrelemos 
Cyberpunk: Apropriação, Desvio e Despesa na Cibercultura. Artigo Apresentado à Compós, 2000. Disponível em http://www.facom.ufba.br/ciberpesquisa

LAND, Nick. Making It with Death: Remarks on Thanatos and Desiring-Production. Journal of the British Society for Phenomenology 24.1 (Jan 1993): 66-76. Machinic Desire. Textual Practice 7.3 (Winter 1993): (p.471-482).

LARROSA, Jorge \& PÉREZ DE LARA, Nuria (orgs.) Imagens do Outro. Petrópolis: Vozes, 1998.

LARROSA, Jorge. Notas sobre a experiência o saber da experiência. Tradução de João Wanderley Geraldi. Conferência proferida no I Seminário Internacional de Educação de Campinas, Unicamp.

LEÃO, Lúcia (org). Interlab - Labirintos do pensamento contemporâneo. São Paulo: Iluminuras, 2002. Iluminuras, 2001. O labirinto da hipermídia - Arquitetura e navegação no ciberespaço. São Paulo:

LESSIG, Lawrence. Free Culture. How big media uses technology and the law to lock down culture and control creativity. New York: Penguin Press, 2004.

LÉVY, Pierre. O que é o Virtual? São Paulo: Ed. 34, 1996.

Cibercultura. São Paulo: Ed. 34, 1999

As Tecnologias da Inteligência: O Futuro do Pensamento na Era da Informática. Rio de Janeiro: Ed. 34, 2000.

LÖWY, Michael. Redenção e Utopia. São Paulo: Cia das Letras, 1989.

LUHMANN, Niklas. A Improbalidade da Comunicação. Lisboa: Veja, 1992.

Introducción a la teoría de Sistemas. México: Universidad Iberoamericana, 1996.

The Reality of the Mass Media. Stanford: Stanford University Press, 2000.

LIMA, Luiz Costa. Teoria da Comunicação de Massa. Rio de Janeiro: Paz e Terra, 1990.

LYOTARD, Jean-François. A condição Pós-Moderna. Rio de Janeiro: José Olympio, 1998.

O Inumano: considerações sobre o tempo. Lisboa: Estampa, 1989.

McCLEARY, Leland Emerson. Aspectos de uma modalidade de discurso mediado por computador. Tese de Doutorado, Linguística, FFLCH-USP, 1996.

MACHADO, Nilson José. Plantares. São Paulo: Escrituras, 1997.

MAFFESOLI, Michel. La Conquête du Présent. Pour Une Sociologie de la Vie Quotidienne. Paris: PUF, 1979.

A parte do Diabo - Resumo da subversão pós-moderna. Rio de Janeiro: Record, 2004.

MANN, Klaus. Mephisto. São Paulo: Estação Liberdade, 2000. 
MARASCO, Thomas G. Diário de Bordo de Um Navegador Solitário. Capturado em: http://www.gquattro.com/personal/thomas

MARCONDES Filho, Ciro. (coord.) Pensar - Pulsar: Cultura comunicacional, tecnologias, velocidade. São Paulo: Edições NTC, 1996.

Vivências eletrônicas. São Paulo, Edições NTC, 1998.

Revista Atrator Estranho. São Paulo: Ed. NTC.

MARCONDES Filho, Ciro. A sociedade Frankenstein. São Paulo, 1991.

Sociedade tecnológica. São Paulo: Scipione, 1994.

SuperCiber: A civilização místico tecnológica do século 21. São Paulo: Edições NTC,

1998.

A Sociedade Frankenstein. São Paulo, Ed. do Autor, 1991. Disponível em:

http://www.eca.usp.br/nucleos/filocom/frank.doc

Cenários do Novo Mundo. São Paulo: Edições NTC, 1998.

O espelho e a máscara. O enigma da comunicação e o caminho do meio. São Paulo:

Humanitas/Unijuí/Discurso Editorial, 2002.

Odeio a Internet! Revista USP, $n^{\circ} 55$, set/out/nov 2002, (p.71-75).

A Produção Social da Loucura. São Paulo: Paulus, 2003

O escavador de silêncios - formas de construir e desconstruir sentidos na

Comunicação. São Paulo: Paulus, 2004.

Até que ponto, de fato, nos comunicamos? São Paulo: Paulus, 2004.

O Princípio da Razão Durante. Trabalho de circulação restrita, 2005.

MARCUSE, Herbert. Eros e Civilização. Rio de Janeiro: Jorge Zahar, 1968.

MARKLEY, Robert, Virtual Reality and Their Discontents. Baltimore: John Hopkins University Press, 1996.

MARTIN-BARBERO, Jesus. Dos meios às mediações - comunicação, cultura e hegemonia. Rio de Janeiro: UFRJ, 1997.

MASSUMI, Brian. A user's guide to Capitalism and Schizophrenia. Deviations from Deleuze and Guattari. Cambridge: Massachusetts Institute of Technology Press, 1992.

MATURANA, H. E VARELA, F. De máquinas e seres vivos: autopoiese - a organização do vivo. Porto Alegre: Artes médicas, 1997.

Editorial Universitaria, 1990.

El árbol del conocimiento - las bases biológicas del entendimiento humano. Santiago: 
McLUHAN, Marshall. Os meios de comunicação como extensões do homem. São Paulo: Cultrix, s/d.

McRAE, Shannon. Carne feita palavra: sexo, texto e o corpo virtual. Disponível em: http://members.fortunecity.com/cibercultura/vol5/carpal.html

MERLEAU-PONTY, Maurice. Fenomenologia da Percepção. São Paulo: Martins Fontes, 1999. SP/RJ: Livraria Freitas Bastos, 1971.

O Visível e o Invisível. São Paulo: Perspectiva, 1992.

1974.

A prosa do mundo. São Paulo: Cosac \& Naify Edições, 2002. Rio de Janeiro: Bloch,

MEYER, G. The social organization of the computer underground. Master's Thesis, Department of Sociology, Northern Illinois University, 1989.

MICHELSON, Annette (org.). Kino-eye, the writings of Dziga Vertov. Berkeley: University of California Press, 1984.

MILLER, Henry. Trópico de Capricórnio. São Paulo, Círculo do Livro, 1975.

MONTESQUIEU, Charles-Louis de Secondat. Essai sur lê goût. Paris: Rivage Poche, 1993.

MOORE, Dinty W. The Emperor's Virtual Clothes: The Naked Truth About Internet Culture. Chapel Hill: Algonquin Books, 1995.

MORAIS, Rodrigo de Oliveira. Zona Autônoma Temporária: Web e Máquinas de Guerra. INTERCOM - IV Encontro dos Núcleos de Pesquisa, NP 08, do $27^{\circ}$ Encontro Anual da Associação Nacional dos Programas de Pós-Graduação em Comunicação, Porto Alegre, 2004.

MORÁN Costas, José Manuel. Novas tecnologias e o Reencantamento do mundo. Rev. Tecnologia Educacional. Rio de Janeiro, v. 23, n. 126, p.24-26, 1995.

MORICONI, Ítalo. A provocação Pós-moderna: Razão histórica e política da teoria de hoje. Diadorim, 1994.

MUMFORD, Lewis, La Première Mégamachine. Diógène, 1966.

Artefacto, pensamiento de la técnica. Buenos Aires: UBA, 1998.

El mito de la máquina I. Buenos Aires: Emecé, 1969.

Paraíso paleolítico: Caketown. A cidade na história. São Paulo: Martins Fontes, 1998.

NAGEL, Thomas. Visão a partir de Lugar Nenhum. São Paulo: Martins Fontes, 2004.

NEGRI, Antonio. Cinco lições sobre o Império. Rio de Janeiro, DP\&A, 2003.

NEGRI, Antonio e HARDT, Michael. Império. Rio de Janeiro: Record, 2001.

Multitude: War and Democracy in the Age of Empire. London: Penguin Press, 2004. 
NEGROPONTE, Nicholas. A Vida Digital. São Paulo: Cia das Letras, 1995.

NIETZSCHE, Friedrich. Assim Falou Zaratustra - Um livro para todos e ninguém. IN: Coleção Os Pensadores. São Paulo: Nova Cultural, 1996.

NOVAES, Adauto (Org.). O Homem-Máquina. A ciência manipula o corpo. São Paulo: Cia das Letras, 2003.

OLIVEIRA, Danielle Naves. O eterno retorno na cibersociedade: processos temporais nas novas tecnologias da comunicação. Dissertação de Mestrado, ECA-USP, 2000.

Poros ou as passagens: reflexões sobre a epistemologia da comunicação. In: COMPÓS - $12^{\circ}$ Encontro Anual da Associação Nacional dos Programas de Pós-Graduação em Comunicação, Recife, 2003.

OLIVEIRA, Nelson. Geração 90 - os transgressores. São Paulo: Boitempo, 2003.

ORLANDI, Eni. P. A linguagem e seu funcionamento: As formas do discurso. Campinas: Pontes, 1987. Análises de Discurso: Princípios e Procedimentos. Campinas: Pontes, 2000.

ORTIZ, Renato. Mundialização e cultura. São Paulo: Brasiliense, 1994. A moderna tradição brasileira. São Paulo: Brasiliense, 1988.

PALÁCIOS, Marcos. Modens, muds, bauds e ftps: Aspectos da comunicação no final do milênio. 1999. Disponível em: http://www.facom.ufba.br/pesq/cyber

PELLEGRINO, Antonia. Blog Inveja de Gato - Um gato brasileiro e vira-lata e meu. 11/11/2003.

PARENTE, André. Imagem-máquina: A era das tecnologias do virtual. Rio de Janeiro: Ed. 34, 1999.

PARSONS, Talcott. The structure of social action. New York: The Free Press, 1968.

PEREIRA, Beltrina Purificação da Côrte. São Paulo: Cidade misturada/cidade inconclusa zapeando a metrópole metalizada. Tese de Doutorado, ECA-USP, 1997.

PINHEIRO, Daniela. Tecla comigo, vai... - porque milhões de brasileiros resolveram procurar um romance na Internet. Revista Veja, nº 1778, 20/11/2002.

PLANT, Sadie. Gozando Futuro Afora. Tradução de Tatiana Rodrigues e Carolina Ouriques, revisado por Francisco Rüdiger. Disponível em: http://members.fortunecity.com/cibercultura/vol5/gozfut.html

POE, Edgar Allan. Histórias Extraordinárias. São Paulo, Círculo do Livro, 1974.

PORTO, Sérgio Dayrell (org.). Sexo, Afeto e Era Tecnológica - Um estudo de chats na Internet. Brasília: UNB, 1999.

PROUST, Marcel. Em Busca do Tempo Perdido. Rio de Janeiro: Globo, 1981.

PRIGOGINE, Ilya. O fim das certezas - Tempo caos e leis da natureza. São Paulo: Unesp, 1996. 
REGIS, Fátima. A subjetividade ciber: ciborgues, ciberespaço e cyberpunk. Revista 404nOtF0und: Ano 3, Vol. 1, no 27, ISSN 1676-2916 - abril/2003.

REID, E. M. Electropolis: Comunication and community on Internet Relay Chat. Honor Thesis, Department of History, University of Melbourne, 1991.

RHEINGOLD, Howard. A Comunidade Virtual. Lisboa: Gradiva, 1992. Virtual reality. Morristown: Cosy Book Nook, 1991.

ROLNIK, Suely. Cartografia Sentimental: Transformações contemporâneas do desejo. São Paulo: Estação liberdade, 1989.

RÖTZER, Florian. Espaço virtual ou espaço mundial. Tradução de Ciro Marcondes Filho. Disponível em: $\underline{\text { www.eca.usp.br/nucleos/filocom/traducoes.html }}$

RÜDIGER, Francisco. Elementos para a Crítica da Cibercultura. São Paulo: Hacker, 2002.

SABBAG, Maria do Carmo. O chat e a percepção lingüística em um curso de inglês on-line. Dissertação de Mestrado: Lingüística Aplicada, PUC - São Paulo - 2002.

SAFATLE, Vladimir. A política do Real de Slavoj Zizek. Revista Trópico. Disponível em: http://www.uol.com.br/tropico/dossie_5_1778_1.shl

SÁNCHEZ, Antulio. La era de los afectos en internet. México: Editorial Océano, 1997.

SANTAELLA, Lucia. Cultura das mídias. São Paulo: Experimento, 2000.

Culturas e artes do pós-humano - da cultura das mídias à cibercultura. São Paulo:

Paulus, 2003.

SANTIAGO, Silviano. Glossário de Derrida. Rio de Janeiro: Francisco Alves, 1976.

SANTORO, L F. Novas tecnologias de comunicação e as necessidades dos produtores independentes. Revista Comunicação e Sociedade. São Bernardo do Campo, n. 20, p.9-28, 1993.

SANTOS, Laymert Garcia dos. Politizar as Novas Tecnologias. São Paulo: 34, 2004.

SAUSSURE, Ferdinand. Cours de Linguistique Générale. Paris: Payot, 1984.

SEMPSEY, J. III. The psyco-social aspects of multi-user dimensions in cyberspace: a review of the literature. Temple University: 1995.

SENNET, Richard. O Declínio do Homem Público. São Paulo, Cia das Letras, 1989.

SEVCENKO, Nicolau. Pós-Moderno: um exercício de descontinuidade. Revista Lua Nova. São Paulo, v. 2, n. 4, p.68-73, 1986.

SFEZ, Lucien. Crítica da comunicação. São Paulo: Loyola, 2000. 
SHANK, Gary. Abductive multiloguing: the semiotic dynamics of navigating the net. The Arachnet Electronic Journal on Virtual Culture, 03/22/1993, Vol. 1 Issue 1. ISSN 1068-5723. Disponível em: http://www.ibiblio.org/pub/academic/communications/papers/ejvc/SHANK.V1N1

SHIELDS, Rob. Cultures of Internet: Virtual spaces, real histories, living bodies. London: Sage Publications, 1996.

SIBILIA, Paula. O homem pós-orgânico - Corpo, subjetividade e tecnologias digitais. Rio de Janeiro: Relume Dumará, 2002.

SILVA, Ana Maria Alves Carneiro. Reconectando a sociabilidade on-line e off-line: trajetórias, poder e formação de grupos em canais geográficos no Internet Relay Chat. Dissertação de Mestrado IFCH/Unicamp - Campinas, Novembro 2000.

SMITH, Marc. e KOLLOCK, Peter (orgs.). Communities in cyberspace. London: Routledge, 1999.

STEWART, Concetta; SHIELDS, Stella F.; MONOLESCU, Dominique; TAYLOR, John Charles. Gender and participation in synchronous CMC: An IRC case study. Disponível em: http://www.emoderators.com/ipct-j/1999/n1-2/stewart.html

STOKINGER, Gottfried. A interação entre cibersistemas e sistemas sociais. Disponível em: http://www.facom.ufba.br/ciberpesquisa/txt_got1.htm

A comunicação como fenômeno emergente. Revista 404nOtF0und, N. 11, Dez/2001.

STONE, Allucquere Rosanne. The War of Desire and Technology at the Close of the Mechanical Age. London: MIT Press, 1995.

STORCH, Léa Waidergorn e COZAC, João Ricardo. Relações Virtuais: O lado humano da comunicação eletrônica. Petrópolis: Vozes, 1995.

STRATE, Lance; JACOBSON, Ronald \& GIBSON, Stephanie B., (eds.) Communication and cyberspace: social interactions in an electronic environment. Cresskill: Hampton Press, 1996.

TAUBIN, Amy. He got game. David Cronenberg's Virtual surreality. Village Voice, 04/1999.

TEIXEIRA, Ivan. Desconstrutivismo. Revista Cult. Fortunas Críticas, N.16, p.34-37, nov/1998.

TESTER, Keith (ed.). The Flâneur. London: Routledge, 1994.

TODOROV, Tzvetan, A conquista da América: a questão do outro. São Paulo: Martins Fontes, 1996.

TÖNNIES, F., On Gemeinschaft and Gesellschaft. Também disponível em: http://www.cf.ac.uk/socsi/frameset_students/introsoc/gemein.html

TOURAINE, Alain. Crítica da Modernidade. Petrópolis: Vozes, 1995.

Poderemos Viver Juntos? Petrópolis: Vozes, 1998.

TRIVINHO, Eugênio Rondini. Estética da Cultura: Comunicação e Pós-Modernidade. Dissertação de Mestrado, ECA-USP, 1992.

Cyberspace: Crítica da Nova Comunicação. Tese de Doutorado, ECA-USP, 1999. 
TURKLE, Sherry. O Segundo eu: Os comportamentos e o espírito humano. Lisboa: Presença, 1989.

Life on the Screen: Identity in the Age of the Internet.

New York: Touchstone Books, 1997.

Identidade na Internet. In: Brockman, John (org.). As coisas são assim. São Paulo: Cia

das Letras, 1997.

VALVERDE, Monclar. A Dimensão Estética da Experiência. Textos de Cultura e Comunicação, ${ }^{\circ}$ 37/38. Salvador: Facom-UFBa, dez 1997.

VELENA, Helena. Dal cybersex al transgender. Tecnologie, identità e politiche di liberazione. Roma : Castelvecci, 1995.

VELHO, Otavio (org). O Fenômeno Urbano. Rio de Janeiro: Jorge Zahar. 1967.

VIANNA, Hermano. Novos sistemas, novos problemas - "Revolução" convulsiona o sistema libertário de uma pequena lista de discussão sobre Gilles Deleuze. Jornal Folha de São Paulo, Caderno Mais!, 7/07/1994, p.6-8.

VONNEGUT, Kurt. Slaughterhouse-Five or The Children's Crusade. A Duty-Dance with Death. New York: Delta Publishing, 1999; Matadouro Cinco ou A Cruzada das Crianças. Lisboa: Caminho, 1990.

WARSHAUER, S. Aesthetic approaches to the designe and study of MUDs (Multi-User Domains) in English and performance studies: Interface, realism and dialetic of interacting. CWRL: Computers, Writing, Rhetoric and Literature, Eletronic Jounal of the computer Writing and Research Labs. U.T. Austin, 1995.

WEINER, Norbert. Cibernética e Sociedade - O uso humano dos seres humanos. São Paulo: Cultrix, $3^{\mathrm{a}}$ edição.

WILSON, Elisabeth. The invisible Flâneur. London: New Left Review, nº 191, 1992.

WOLF, Mauro. Teorias da Comunicação. Lisboa: Presença, 1995.

WRAY, Stefan. Rhizomes, Nomads, and Resistant Internet Use. 1998.

WULF, Christoph. Imagem e Fantasia. Conferência promovida pelo SESC, São Paulo. Tradução: Tereza Maria Souza de Castro Disponível em: http://www.sescsp.org.br/sesc/images/upload/conferencias/115.rtf

ZIZEK, Slavoj. Jacques Lacan. New York: Taylor \& Francis, 2002. (4 vol.).

A Paixão pelo Real. Entrevista concedida ao Jornal Folha de São Paulo. Caderno Mais!, 30/11/2003, p.4-7.

Bem-Vindo ao Deserto do Real. São Paulo: Boitempo, 2003.

Gaze and voice as love objects. Durham: Duke University Press., 1996. 